\title{
STUDIES IN STRINDBERG
}

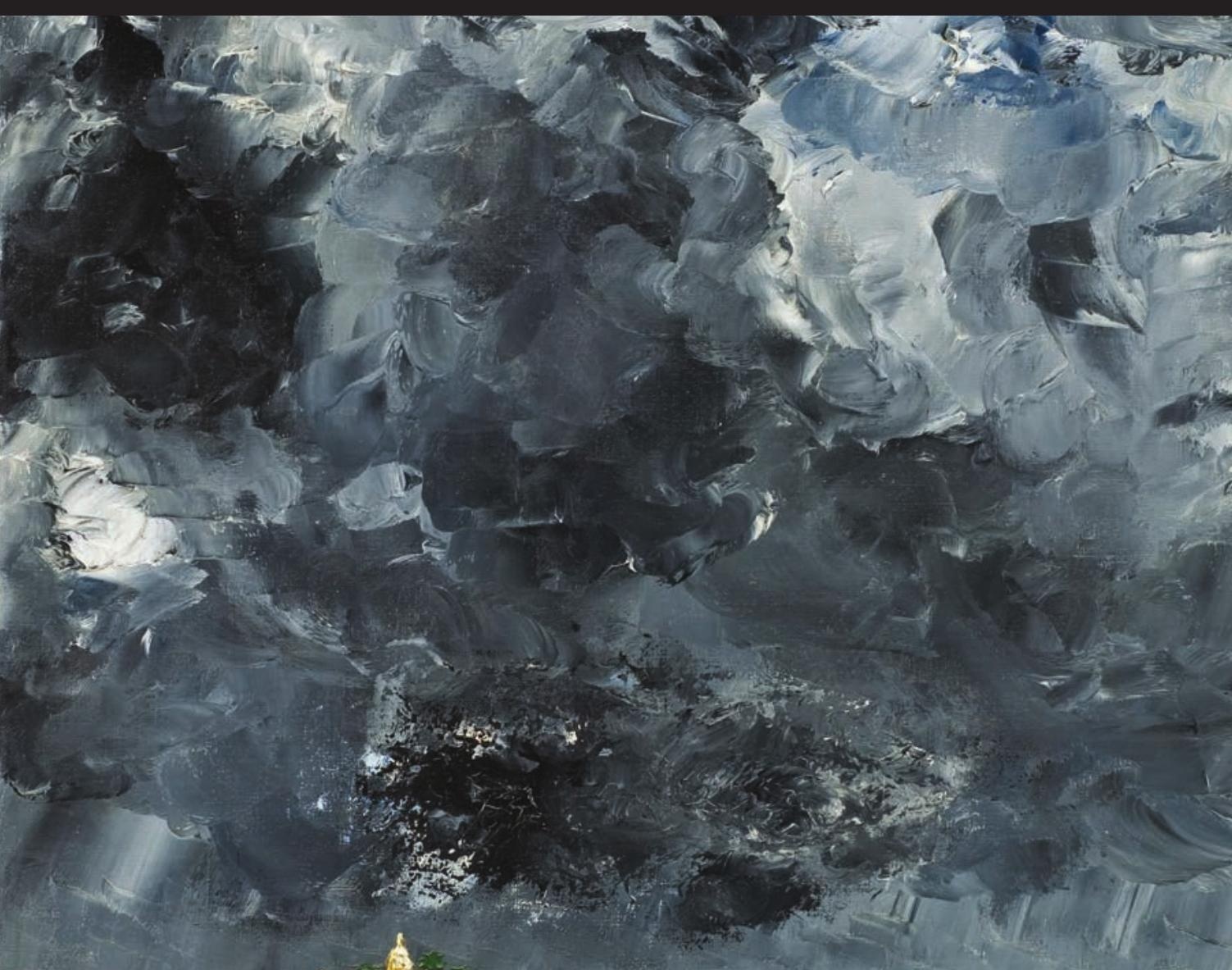

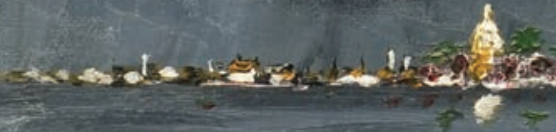

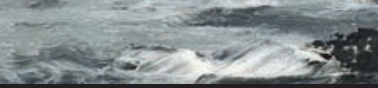

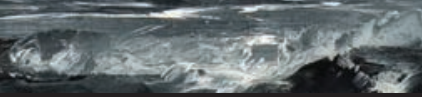
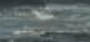


\title{
Studies in Strindberg
}

\author{
Michael Robinson
}

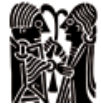

Norvik Press

$$
\text { ]u[ }
$$

ubiquity press

London 


$$
\begin{gathered}
\text { Published by } \\
\text { Ubiquity Press Ltd. } \\
\text { Gordon House } \\
\text { 29 Gordon Square } \\
\text { London WC1H 0PP } \\
\text { www.ubiquitypress.com } \\
\text { and } \\
\text { Norvik Press } \\
\text { Department of Scandinavian Studies } \\
\text { University College London } \\
\text { Gower Street } \\
\text { London WC1E 6BT } \\
\text { www.norvikpress.com }
\end{gathered}
$$

Text (C) Michael Robinson 1998

Original edition published by Norvik Press 1998

This edition published by Ubiquity Press Ltd 2013

Cover illustration: The Town (1903) by August Strindberg,

Nationalmuseum, Stockholm. Via Wikimedia Commons. Source: Google Art Project. Available at: https://commons.wikimedia.org/wiki/File:August_Strindberg_-_The_

Town_-_Google_Art_Project.jpg

Typeset in Adobe Garamond Pro by Ubiquity Press Ltd

Printed in the UK by Lightning Source

ISBN (paperback): 978-1-909188-02-0

ISBN (EPUB): 978-1-909188-06-8

ISBN (PDF): 978-1-909188-10-5

DOI: http://dx.doi.org/10.5334/bac

This work is licensed under the Creative Commons Attribution 3.0 Unported License. To view a copy of this license, visit http://creativecommons.org/licenses/by/3.0/ or send a letter to Creative Commons, 444 Castro Street, Suite 900, Mountain View, California, 94041, USA. This licence allows for copying any part of the work for personal and commercial use,

providing author attribution is clearly stated.

Suggested citation:

Robinson, M 2013 Studies in Strindberg. Norvik Press/Ubiquity Press. DOI: http:// dx.doi.org/10.5334/bac

To read the online open access version of this book, either visit http://dx.doi.org/10.5334/bac or scan this $\mathrm{QR}$ code with your mobile device: 
For B. E. R.

and

in memoriam G. E. R. 



\section{Contents}

A Note on the Text

An Introduction

1. Leaving Gravesend at Last, or Introducing Strindberg to England 1

Narrative, Plot and Self

2. Translating the Self

3. Life Plots and Letters 25

4. History and His-Story 39

5. 'P-aris': Note for an Unwritten Volume of Strindberg's Autobiography

Plots, Plays and Performance

6. Naturalism and the Plot in Creditors

7. Prisoners at Play: Form and Meaning in The Dance of Death and Beckett's Endgame

8. 'Spela den så att Pontoppidan och Fru Nansen få blåskatarrh': Strindberg's Correspondence with Actors and Directors

From Naturalism to Modernism

9. Towards a New Language: Strindberg's Break with Naturalism 105

10. 'New Arts, New Worlds!': Strindberg and Painting 115

11. Strindberg and Musical Expressionism in Vienna 135

A Penance for Strindberg

12. Acting Women or The Performing Self

Notes

Index 



\section{A Note on the Text}

Wherever possible references to Strindberg's works are to the new edition of Samlade Verk currently under publication (hereafter SV). Quotations are identified in parenthesis within the text thus [SV 4, 240]. Otherwise John Landquist's edition of Samlade Skrifter (1912-20, hereafter SS) has been used. Volume and page number are likewise given in arabic numerals in parenthesis after a quotation thus [SS 54, 235]. SgNM denotes Strindberg's so-called 'Gröna säcken' (The Green Sack), encompassing the drafts, notes and manuscripts he originally preserved in a green linen portmanteau while travelling. These are now deposited, along with much other material, in the Royal Library Stockholm, in sixty-nine box files, transferred there from a previous deposition in Nordiska Museet. The inventory of the contents undertaken by Margareta Brundin and catalogued by Barbro Ståhle Sjönell now enables an item in Gröna säcken to be identified with some precision. Thus SgNM 15: 4,7 refers to Box 15 , folder 4, page (or item) 7. (For later items identification is sometimes by Box only.) Strindberg's letters, collected in twenty volumes as August Strindbergs brev, edited by Torsten Eklund and Björn Meidal (Stockholm, 1948-1996) are identified in parenthesis in the text with the volume number in Roman numerals. Where an English translation exists in the two-volume collection of Strindberg's Letters, edited and translated by Michael Robinson (London and Chicago, 1992), the page reference is also included in parenthesis in the text. [VI, 45; 1, 273] thus denotes volume VI, page 45 of the Swedish edition and volume 1, page 273 of the two-volume English edition. References in the notes to $S E$ (Cambridge, 1996) are to August Strindberg, Selected Essays, edited and translated by Michael Robinson (Cambridge University Press, 1996). 

An Introduction 



\section{Leaving Gravesend at Last, or Introducing Strindberg to England}

'Address for the time being: Gravesend by London 12 Pelham Road. (England) Best wishes to your brother and sister Yrs. August Sg' [IX, 191]. This hastily written and unpunctuated message appears on an undated postcard from Strindberg to his eldest daughter, Karin, now living with her mother, Siri von Essen, in Finland. Strindberg had seen neither his three children nor his first wife since leaving Sweden in September 1892 for what was to prove an extended self-exile spent mainly in Germany, Austria and France. Here, however, he was keeping his first family tenuously in touch with his movements following his recent second marriage to the young Austrian journalist Frida Uhl. The ceremony had taken place on Heligoland in May 1893, with two local pilots as witnesses, because the recent cessession of the island to Germany in 1890 meant that British marriage regulations still obtained there, and no banns were required. Now he and Frida had proceeded to England to enjoy (though that is hardly the word to describe so disastrous a venture) a combination of business trip and honeymoon.

England - or 'die Fraueninsel' as he described it in an equally laconic note to the Finland-Swedish author Adolf Paul [IX, 196; 2, 457] - has rarely been closely associated with Strindberg, either during his lifetime or since, and the three weeks that he spent there in 1893, firstly in Gravesend, where he and Frida came ashore, and then in London where they lived in Pimlico, at the home of the theatre director J.T. Grein, are emblematic of the difficulty with which he has subsequently found acceptance here.

Strindberg's immediate problems stemmed in part at least from Grein. He had been encouraged to leave Germany by the latter's vague promise to mount a production of The Father at his recently established Independent Theatre, where it would be a Scandinavian follow-up to the production of Ibsen's Ghosts with which the theatre had opened the previous year. However, although he advertised Strindberg's play among his future repertoire on the playbill for his inaugural production, Grein failed whatever promise he may have given. In fact he travelled abroad during the time Strindberg spent in London and he would later write that he could neither find an English actress prepared to play 
the part of Laura nor obtain the Lord Chamberlain's permission to put the play on in the first place.

Problems also arose where the publisher William Heinemann was concerned. Strindberg not only believed that Heinemann was prepared to publish his sequence of five meditative poems Somnambulistic Nights in Broad Daylight (1884-90); he also thought that he was interested in commissioning English editions of some of his novels. Heinemann seems to have had no such serious intention, however, and Strindberg's initial enthusiasm for England as the latest of several promised lands in his career rapidly deteriorated. 'England is a southern country,' he had written to Paul, shortly after arriving in Gravesend, 'with roses high on the house walls even at Whitsuntide, laurels in flower as tall as two men and enormous, real chestnut trees!' [IX, 198]. But within a month the entire country had become for him a 'robbers' nest'. He informed Paul that he had been 'on the brink of getting rabies in all the heat and pit coal' [IX, 215], and, without waiting to see any of his schemes mature, he hurried back to the more familiar ground of Germany. Moreover, as so often in his career, business failure rapidly soured his personal relationships, this time with Frida who ominously remained behind in London 'to take care of [the] theatres and publishers' [IX, 215]. For having studied at a convent school in Hampstead a few years earlier, she spoke the language fluently, unlike Strindberg, whose poor English left him at an infuriating disadvantage.

For many years Strindberg's prospects in England hardly improved. The first of his plays to reach the English stage, for example, was The Stronger, in 1906. It was played to little acclaim, and when, three years later, it was performed again at His Majesty's Theatre on 9 and 10 December 1909 together with Act Five of Ostrovsky's Vassilissa Melentieva, this was not on Strindberg's account but because in the role of the silent Mlle Y it provided the celebrated Russian actress Lidija Jarvorskaja (the Princess Bariatinsky) with a vehicle which could not be impaired by her as yet imperfect grasp of English. ${ }^{1}$ Moreover, when he was performed on his own account the early critical reception, which dismissed his plays as 'too personal', 'unbalanced', 'hate-filled', 'egotistical', 'morally questionable', 'mad', the work of 'a charlatan, more disagreeable in mind than Ibsen', 'irredeemably pessimistic' and 'without any sense of humour', articulates a response that has, unfortunately, changed little over the years. ${ }^{2}$ 'It is a waste of time to translate into English plays like... Strindberg's The Creditors,' observed a reviewer of The Incorporated Stage Society's 1912 production of the play in Elie Schleussner's translation, 'They do not amuse, interest, or instruct ${ }^{3}-$ a response which is sometimes echoed even by so experienced and able a translator of his plays as Michael Meyer, in his major biography of Strindberg (1985). Meyer concludes that with the exception of one or two works that can flourish with the right performer or audience 
only nine of Strindberg's plays remain performable today, and of these several require careful cutting. Furthermore, he adds that Strindberg's novels (with the exception of The People of Hemsö) and the autobiographical books (with the exception of Inferno) are of little interest outside Sweden, except perhaps in Germany where, according to Meyer, 'even the best of that country's novelists have often shared Strindberg's faults.' ${ }^{\text {' }}$

One begins to see why Strindberg, unlike, for example, Ibsen and Chekhov, has made comparatively little headway in this country. Whereas their major plays were domesticated to the British stage with relative ease, and were eagerly seized upon as performance vehicles by actors both then - at the end of the nineteenth century - and now, in regular revivals with star-studded casts, Strindberg has remained an elusive figure, at best only partially known. Whereas both Ibsen and Chekhov rapidly found advocates for their respective series of dramas on themes from contemporary life (and few playwrights have been received by performers with as much excitement as Ibsen, notwithstanding the public opprobrium he initially provoked), Strindberg's seemingly far less coherent oeuvre makes him very much more difficult to pin down. Apart from the fifty-seven odd plays written for the most part in four main bursts between 1869 and 1909, his work includes seven novels, twelve volumes of short stories on both contemporary and historical themes, several works of history, including, in the two-volume The Swedish People, the first major history of Sweden narrated from an ethnographic perspective, ten volumes of autobiography plus his recently published Occult Diary, numerous studies in natural science (including botany, chemistry and geology as well as alchemy), works of poetry, satire and linguistics alongside numerous essays on politics, art, psychology and other subjects - and this is not to mention either the twenty-two volumes of his extant correspondence or his important experimental work as a painter and photographer.

Moreover, even if a comparison is restricted to their work for the theatre, Ibsen and Chekhov, having discovered the basic format of their major sequences of plays on contemporary subjects then continued to work with a similar dramatic structure, which they developed and refined but did not essentially change, whereas Strindberg, having started out (like Ibsen) writing historical drama, including Master Olof in 1872, first established himself as a major naturalist with The Father, Miss Julie and Creditors in the late 1880s, and then remade, or reinvented, himself as a writer in order to return to the theatre in 1898 with To Damascus, the first of what he would subsequently call his 'dream plays' [SV 46, 7]. At the same time he also embarked upon the most significant sequence of historical dramas since Schiller and Shakespeare (eleven plays on Swedish themes and four on 'World-Historical subjects', all written between 1899 and 1909), wrote morality plays about crime and punishment 
like Advent (1898), plays with rustic settings like The Virgin Bride (1901) and Midsummer (1900), a Parisian boulevard drama like Crimes and Crimes (1898), and the four principal chamber plays of 1907, including The Ghost Sonata and The Pelican.

Strindberg's first English reviewers were not, of course, aware of this multifacetedness. Nor could they have been. They had only a few, generally compromised translations on which to base their misunderstandings. Many of these first translations were made not from the original Swedish but from Emil Schering's German versions, themselves frequently open to question, and there was no one on hand to undertake his transposition into English as there was with William Archer for Ibsen or Constance Garnett for Chekhov. This neglect compares significantly with Strindberg's substantial reputation in Germany during the first twenty-five years of this century or the attention paid to him in France following the Second World War, where Roger Blin's 1949 production of The Ghost Sonata was an important precursor for his staging of Waiting for Godot in 1953, ${ }^{5}$ and even though the situation improved considerably when Elizabeth Sprigge and Michael Meyer provided reliable translations of a number of the major play texts in the 1960s, several of the most important dramas have still not found an established place on the English stage, and many of the novels and other prose works remain untranslated. Thus, The Pelican was performed for the first time in this country by an amateur group at Leeds University as late as $1950,{ }^{6}$ and The Virgin Bride still awaits its English stage premiere in spite of Michael Meyer's twenty-five-year-old, actable translation. The Ghost Sonata, meanwhile, had its English premiere in 1926 but was not performed again professionally for fifty years while To Damascus has still not been presented as a whole, even though Part One was performed once during the 1930s and again in 1975 at the Traverse Theatre in Edinburgh, where it was praised by Alien Wright in The Scotsman as 'a play so packed with ideas and invective that it makes most contemporary dramas seem trivial.'

In contrast to Ibsen and his magisterial entry into the British theatrical tradition Strindberg's arrival has therefore been halting and slow. Apart from his disturbing variety, there are several reasons why this should have been so. The first to present Strindberg and his theories on drama to an English-reading public was the energetic Irish politician and man-of-letters, Justin Huntly McCarthy, who contributed an incomplete translation of the Preface to Miss Julie to The Gentleman's Magazine in August 1892, and a longer essay, in which Strindberg was praised as the most prominent Scandinavian dramatist after Ibsen, to The Fortnightly Review, the following month. As usual, Strindberg was quick to respond to such attention. His letters indicate that he was a reader of this well-respected journal during the 1880s and when he became aware of McCarthy's article, he promptly brought it to the attention of his current 
French translator, Charles de Casanove: 'Finally just a couple of words to assist your efforts and to lend a little weight to your thinking about my writing. The Fortnightly Review in London, a highly esteemed journal, has just published an essay on $M^{\text {lle }}$ Julie, written by M. Justin Huntly McCarthy. It is very favourable (I have read it), which surprises me with regard to the puritanism of chaste England' [IX, 73]. He then referred his young friend Birger Mörner to this pioneering analysis of his work, which Mörner would, in a somewhat reduced form, eventually publish in Swedish translation in En bok om Strindberg, the pioneering collection of essays on Strindberg's work that he edited, together with Gustaf Fröding, in 1894. As was so often the case, Strindberg functioned here as his own, considerable impresario.

However, apart from McCarthy Strindberg lacked an influential supporter in leading English literary circles during these crucial early years. While Ibsen had important advocates among established writers like Henry James, new talents like James Joyce, or men of letters like Edmund Gosse and William Archer, both of whom knew Norwegian and, especially in Archer's case, proved crucial to his acceptance, there was no one who played a similar role where Strindberg was concerned. 'C'est du Nord aujourd'hui que nous vient la lumière' - many had occasion to quote Voltaire's words here and there in Europe at this time, but where England was concerned, there could be only a single such source of light, and that was Ibsen.

Which is not entirely to overlook George Bernard Shaw. As a friend of both Grein and Archer, a familiar of London's leading actors and (particularly) actresses, and a follower of the independent theatre movement for which he also wrote, Shaw was certainly aware of Strindberg. His sister, Lucie Carr Shaw, assisted in the translation from Schering's German version of Miss Julie for its first English performance by The Adelphi Play Society in April 1912. And Shaw's own admiration for, and curiosity about, Strindberg was so great that he visited him in Stockholm in July 1908. Together with his wife, Charlotte, Shaw met him at the recently opened Intimate Theatre where Strindberg's co-director August Falck and the latter's wife, Manda Björling, had been hastily recalled by Strindberg from their summer holidays to take part in a private morning performance of the play for the Shaws and himself. It was thus in Shaw's company that Strindberg saw his most celebrated play on stage for the first time (although he had been present in Copenhagen for its world premiere in 1889, it seems he did not watch the performance at the Copenhagen University Student Union in which Siri von Essen played the role of Julie). This may explain why, just before she went on stage, he should have asked Björling as Julie to 'take the whole thing a little easily, otherwise it'll upset me so.' ${ }^{8}$ As it was, the performance ended in praise from Strindberg to Björling for her 'great, beautiful and truthful acting' [XVII, $10 ; 2,792$ ], 
doubts from Shaw's side about the viability of a théâtre intime of this kind, and on Strindberg's part a typical dénouement. For he appears to have been greatly irritated by Shaw's wife and her polite conversation and when he could bear it no longer, he announced pointedly that in ten minutes time he would have an acute attack of his 'secret illness'. Or as Shaw described it, in a postcard to William Archer: 'After some conversation, consisting mainly of embarrassed silences and a pale smile or two by A.S. and floods of energetic eloquence in a fearful lingo, half French, half German, by G.B.S., A.S. took out his watch and said, in German: "At two o'clock I am going to be sick." The visitors accepted this delicate intimation and withdrew.'

In spite of this intermezzo, Shaw continued to take an interest in Strindberg's plays. In March 1910, for example, he wrote again to Strindberg asking his permission, on Sir Herbert Beerbohm Tree's behalf, to mount a production of his early (1882) fairy-tale play, Lucky Peter's Journey, at His Majesty's Theatre. According to Shaw, the play would suit a theatre which had recently enjoyed great success with both J.M. Barrie's Peter Pan and Maeterlinck's L'Oiseau bleu. Strindberg seems to have been understandably concerned to draw Shaw's attention to other possibilities, and in particular to his later, more radical work. For, as Björn Meidal points out [XVIII, 258], a further letter to Strindberg from Shaw, dated 29 March 1910, suggests that he had replied to Shaw's proposal with a copy of the recently written The Black Glove and also drawn his attention to both The Virgin Bride and The Dance of Death. Neither of these would sit easily with Peter Pan, of course, and Shaw wrote back:

If Lycko Per is what you describe it to me, you must have been inspired directly by heaven to write it for... the British public.... It seems to me that the best thing you can do is to let Tree have Lycko Per on condition that it is not to be produced until he has performed Svarta Handsken [The Black Glove], or whatever other play you may select, at the Afternoon Theatre...; Unfortunately I cannot read Swedish; but I see that a good deal of Svarta Handsken is in verse. This is a terrible difficulty.... If Totentanz and Kronenbraut are in prose, perhaps it might be better to suggest them. ${ }^{10}$

However, although he might act as an intermediary in this way, Shaw wrote no 'Quintessence of Strindberg' or anything comparable to his Quintessence of Ibsenism, which was to colour the English view of Ibsen for so many years. Moreover, while it is open to the reader to trace possible echoes of Strindberg in Shaw's plays, there was no dramatist writing in England on whose work Strindberg's dramaturgy had imprinted itself as deeply as it had, for example, on Eugene O'Neill's in the United States. The nearest is perhaps Sean O'Casey who wrote to the actor Robert Loraine: 'Strindberg, Strindberg, Strindberg, the greatest of them all... Barrie sits mumbling as he silvers his little model 
star and golds his little model suns, while Strindberg shakes flame from the living planets and the fixed stars. Ibsen can sit serenely in his Doll's House, while Strindberg is battling with his heaven and his hell'.11 But then no British playwright of the period had the kind of opportunities to discover Strindberg that Emil Schering's translations and Max Reinhardt's productions of his work afforded their contemporaries in Germany. According to Edward Gordon Craig, who also visited Strindberg in Stockholm, though with scant return for his efforts, ${ }^{12}$ Schering 'talked, walked, breathed and lived nothing but Strindberg', and Reinhardt's versions of The Pelican, The Dance of Death, A Dream Play and The Ghost Sonata had an important part to play in helping to create the modern movement in the theatre. ${ }^{13}$ Moreover, if the British theatre lacked its Reinhardt, there was also no English Antoine, Lugné-Poë or Vakhtangov to put on his plays, as they had done in France and Russia, where Erik XIV, with Michael Chekhov in the title role, was performed at the Moscow Arts Theatre in 1921.

Another reason for Strindberg's faltering introduction to England is the immediate constituency to which his plays might have appealed. Again, the comparison with Ibsen is instructive. Among those who first accepted Ibsen with alacrity were actresses such as Janet Achurch, Florence Farr and Elizabeth Robins. Like Karl Marx's daughter, Eleonora Aveling, who translated $A$ Doll's House, An Enemy of the People and The Lady from the Sea into English, Robins also learnt some Norwegian in order to get her hands on his plays as soon as possible for, seeking the rights to stage them, she could not wait until they had been translated. Robins played the central female role in the first English production of several of Ibsen's plays including Hedda Gabler, Hilde Wangel and Ella Rentheim. Her correspondence with Henry James betrays just how exciting it was to wait for a new Ibsen play to arrive. 'Actors were coming to realize that "Ibsen made reputations", she remarked. 'What you won't be able to imagine (unless you are an actress in your twenties) is [simply] the joy of having in our hands... such glorious and actable stuff.' ${ }^{14}$ Moreover, there was an obvious link between the plays that she and her colleagues admired and their predicament as women. Many of these actresses were involved in the suffragette movement, and Ibsen's plays not only gave them exciting parts but roles and images with which they could identify.

On the other hand, Strindberg was handicapped by his reputation as Ibsen's misogynistic antithesis. What could easily be taken for the first serious attempt to engage with Strindberg's ideas in English - a contribution that appeared well-informed because it was based on personal experience - was a chapter on 'The Women Haters, Tolstoy and Strindberg' in We Women and Our Authors (1899), the English version of a German study written by Strindberg's old continental enemy, Laura Marholm-Hansson. Certainly no one at that time 
appears to have learnt Swedish in order to read Strindberg. When a writer like George Egerton (born Mary Chavelita Dunne) looked elsewhere in Scandinavia than to Ibsen for inspiration in her collection of stories Keynotes (1893), it was to Bjørnson or Hamsun (whom she also translated) that she turned, rather than to Strindberg.

Strindberg's principal reputation rests with his plays, of course. But without a stable performance tradition, of the kind that has emerged in Germany and (on occasion) in France as well as in Scandinavia, it is impossible to fully realise his dramaturgy. For the last one hundred and twenty years the English performance tradition has been dominated by realism whereas the tradition which made Strindberg a major figure in the European theatre German expressionism - has never had any real success in England. The really significant Strindberg productions in England can be counted almost on the fingers of one hand: Robert Loraine as the Captain in The Father in 1927, Michael Redgrave and Trevor Howard in the same role in 1948 and 1964, Olivier as Edgar in The Dance of Death in 1967, Mike Ockrent's production of To Damascus in 1975 and Suzanne Bertish as Tekla in Creditors in 1986. Miss Julie was not performed outside the private theatres before 1939 because the censor denied the play a public licence, and the title role has never been identified with a major English actress. As Michael Meyer rightly points out, in an essay on Strindberg's reception on the English stage, there is an essential difference between English and Swedish performance styles:

In the Swedish theatre, as in the German, the unforgivable sin is to underact. In England, it is to overact; how often have we not seen our best actors, when faced by the peaks of Othello and King Lear, take refuge in gentlemanly underplaying or the evasiveness of theatrical fireworks? It is no coincidence that the only two actors who have fully succeeded in Strindberg in England, Robert Loraine and Wilfrid Lawson, have been actors of most unEnglish, one might almost say continental vehemence, and consequently difficult to cast in roles of ordinary human dimensions. For a parallel reason, there has never yet... been an adequate Miss Julie in England. ${ }^{15}$

Indeed, the following anecdote may be taken as symptomatic. When Loraine was to play the role of the Captain and read The Father aloud to his wife for the first time, she is said to have fallen to her knees before him when he was no more than half way through the text and assured him in passionate tones that his children were his own, and that he was not to believe a word of the play. To which Loraine is supposed to have responded: 'If it upsets you like that, there must be something in it. ${ }^{36}$

Finally, it is worth noting that Strindberg lacked not only a viable theatre and an energetic translator to give him the kind of foundation provided by 
Reinhardt and Schering during the early years of the century in Germany or someone to take on the role assumed by Archer and then by Shaw in Ibsen's case in Britain: he also had to do without the kind of academic understanding he received in the United States where at least three important studies of his work had been published by the close of the 1930s, only one of them on his plays. Even today, C.A. Helmecke's Buckle's Influence on Strindberg, Harry V. Palmblad's Strindberg's Conception of History and Carl E.W.L. Dahlström's Strindberg's Dramatic Expressionism, are all still worth consulting, ${ }^{17}$ whereas of the few books on Strindberg published in Britain before the centenary of his birth in 1949 the same might be said only of Joan Bulman's study of Shakespeare's influence on Strindberg's history plays, Strindberg and Shakespeare, which appeared in 1933. Otherwise the only works in book form that might give the English reader pause are (possibly) Lizzy Lind af Hageby's personally coloured but interesting August Strindberg. The Spirit of Revolt from 1913, which was reviewed in The Academy as 'a book in defense of one who needs it, ${ }^{18}$ and the English version of Frida Uhl's still more personal and compromised Strindbergs andra hustru which appeared as Marriage with Genius, in 1937. Indeed, as late as 1962, he continued to be compared (by F.L. Lucas) to Ibsen and was as usual found wanting as a 'maniac misogynist' who 'tended to debase the world's moral currency' and possessed 'very little sense of the value of sense'. Lacking any notion of irony, Lucas, who at one point wishes the characters of Tennessee Williams's Cat on a Hot Tin Roof condemned to 'a humane and efficient gas-chamber', now subjects Strindberg to the kind of opprobrium once lavished on Ibsen, at the end of the nineteenth century. Thus, he concludes, of one of Strindberg's most artistically achieved works, the comic novel The People of Hemsö: 'There is not a single attractive character no touch of that human warmth, sympathy and compassion that pervade the work of finer minds. All Strindberg's gifts of style and imagination, here also, are cheated of real excellence by his warped and poisoned personality'. ${ }^{19}$

This volume seeks in small measure to redress some of this neglect, and certainly to counterbalance the vituperation of men like Lucas. All of the essays are concerned, either deliberately or by default, with facilitating a re-evaluation of Strindberg in the English-speaking world. Taken together with the letters translated in the two-volume collection of Strindberg's Letters, ${ }^{\prime 20}$ in which Strindberg is placed within a Scandinavian as well as a European context, and is given the space he always claimed should be his to tell his own story, they consider a number of subjects rarely addressed before, at least in English (for example, his painting and his thoughts on acting and directing), while they also provide further discriminations on his autobiographical practice and the way in which he designed his life in order to reproduce himself in language and on stage. 
The focus in all these essays is principally on Strindberg the writer, however, not his biography, and my concern is with his artistry even when his attention turns (as it so often does) to his own autobiographical image. Only two items here are concerned solely with the plays, and one of those is a comparative study, which places Strindberg at the outset of a theatrical tradition that issues in the claustrophobic dramas of Samuel Beckett. The remainder circle around several recurring themes, including his frequent self-dramatization and the attempt, to which Strindberg is continually drawn, to represent himself in language, on the one hand, and to his obsessive concern with plots and plotmaking, both on the stage and in his own life, on the other. Moreover, this urgent search for consonance and order in which he seeks confirmation of that universal and personal masterplot that would endow his private experience with meaning is closely linked to the third of my main concerns and the central event in this life, namely his so-called Inferno crisis of the mid-1890s which emerges here as a peripeteia partly stage-managed by Strindberg himself in order that he might, not least by his experiments as a painter, replace the literary naturalism of the 1880s in, for example, Miss Julie and The Son of a Servant, with the modernist aesthetic of To Damascus, Inferno and A Dream Play. This was Strindberg's most remarkable achievement as a writer. For while he occupies a position alongside Zola and Ibsen, on the one hand, he is inescapably linked with Witkiewicz and Beckett, on the other. It is an achievement in the theatre commensurate with that of Freud in converting nineteenth-century psychology into psychoanalysis and Schoenberg's substitution of the twelve-tone scale for the building blocks of romanticism in music; thus the way in which Strindberg, almost uniquely, effected this transition between the documentary tendencies of a naturalism he so frequently interpreted in terms of his own image and a modernism engaged in finding a language in which to articulate the new inwardness it was preoccupied in mapping, is a central concern in almost every one of these essays.

Meanwhile the final essay, on 'Acting Women', serves perhaps as a kind of penance for devoting so much time to Strindberg, the 'woman-hater'. But while it is true that the latter is mentioned in it only in passing, the examination of the idea of character and the nature of the performing (supposedly female) self with which this essay is concerned, is related to reflections elsewhere in this volume on the autobiographical self by Strindberg in, for example, The Son of a Servant, and to his eloquent account of the characterless, modern character in the Preface to Miss Julie. 'As modern characters living in an age of transition more urgently hysterical at any rate than the one that preceded it,' he writes there,

I have depicted the figures in my play as more split and vacillating, a mixture of the old and the new, and it seems to me not improbable that 
modern ideas may also have permeated down by way of newspapers and kitchen talk to the level of the servants.... My souls (characters) are conglomerates of past and present stages of culture, bits out of books and newspapers, scraps of humanity, torn shreds of once fine clothing now turned to rags, exactly as the human soul is patched together... [SV 27, $104-5]$

This modern self, which Strindberg first properly identified in the self-analysis he conducted in order to write The Son of a Servant, informed both his principal genres (the plays and his letters) in which he continually divided, multiplied and masked himself in a complex ontological game. When he is at his apparently most direct and self-revelatory he may well be diverting attention skilfully away from something even more significant while when he writes a seemingly more objective portrait of 'someone else' (Miss Julie, for example, or Gustaf Trolle in The Protector of the Realm (Riksförestandaren of 1909), he can be at his most obliquely self-revealing. ${ }^{21}$ Moreover, as he recognizes himself, in concluding his autobiography [SV 21, 215], when he transposes himself so single-mindedly into language he in fact disperses himself among the pages of his books, from where he emerges to solicit the reader's attention as a multiple figure of the text. Similarly, in a widely prevalent trope about the nature of acting, an actor likewise disperses himself among his parts. Thus, both the autobiographical writer and the actor appear to have liberated themselves from their physical, empirical existence and abandoned themselves promiscuously to a world of signs without firm reference points.

And here is the great paradox of Strindberg's project: the 'truth teller' (or 'sanningsägaren') that he so often aspired to be is linked to a theatricality that is commonly associated with the creation of dubious illusion and hypocrisy. Moreover, the transparency of the self at which (following Rousseau) the autobiographer might be presumed to be aiming is obscured by the art of feigning and dissembling at which the actor excels. Character, as Strindberg discovers, is a role, or rather, not a singular identity but a multiplicity of incarnations which ensure a fundamental instability that he both detests (when it manifests itself in the form of an actress, like his alter ego's partner, Maria, in the autobiographical fiction A Madman's Defence (1887-8), who lives 'an actress's dissolute life' $)^{22}$ and yet recognizes in himself, in his own existential variety, where it becomes precisely that troublesome and dangerous modernity that is associated, towards the end of the nineteenth century, with (among other things) the feminine, the theatre and what Nietzsche calls 'the hocuspocus of the actor. ${ }^{23}$

Originally written to the moment, for the more or less fugitive world of conferences and inaugural lectures, I have occasionally adapted an essay so that it might find a more natural place alongside its companions in this volume. I 
have also corrected a number of errors and infelicities and taken some account of subsequent scholarship, my own and other people's, but I have resisted the temptation that publication in book form brings of a wholesale rewriting. In any case these essays are of a piece with my earlier study Strindberg and Autobiography. Writing and Reading a Life (Norwich, 1986) and my more recent editorial scholarship with the two-volume Strindberg Letters (London and Chicago, 1994) and Strindberg's Essays (Cambridge, 1996), and share with them the preoccupations explored here.

My thanks to the universities of Amsterdam, Birmingham, Cambridge, East Anglia, Helsinki, Stockholm and Washington, and to the Gorky Institute in Moscow, the Royal Dramatic Theatre in Stockholm and the Adelbert Stifter Institute in Linz, where I was first given the opportunity of approaching these topics. My thanks also to those colleagues with whom I have had the chance of discussing the ideas advanced here. To Margareta Brundin, the curator of the Strindberg collection in the Royal Library in Stockholm, I am indebted both for the generous help she has always extended me over many years when consulting Strindberg's manuscripts, and for the illustrations included here. 
Narrative, Plot and Self 



\section{Translating the Self}

The actor, it appears, lives a profusion of roles in other people's eyes just as (according to Rousseau, in the Discours sur les sciences et les arts) social man lives in the opinion of others, and presents himself to those around him in a series of (dis)guises. Consequently, Rousseau, who distrusted both these public arenas of display and dissembling, while at the same time entertaining grave doubts about his ability to present himself to others in public as he felt and knew himself to be, turned to autobiography in order to retrieve a just image of himself from the many misconceptions which he believed that other people held about him. His gaucherie and inability to improvise a telling response in the course of general conversation made him unable to compose himself sufficiently in public in order to counter these misconceptions in person. Therefore writing an autobiography was for Rousseau the necessary substitute for the inadequacies and embarrassment of what he experienced in an interlocutory situation, a domain where he might recompose himself in retrospect. 'The role that I have taken of writing and of concealing myself is precisely that which suits me,' he claimed; ${ }^{1}$ unlike speech, which seems always to obscure his intentions and imprison him within the confines of the character with which he is endowed by others, writing will permit him to 'render my soul transparent to the eyes of the reader' (rendre mon âme transparente aux yeux du lecteur). ${ }^{2}$

Like Rousseau, Diderot, in Le Paradoxe sur le comédien, also alludes to moments of personal experience during which he found it impossible to represent his true feelings directly to a conversational partner. He, too, frequently portrays himself as undone by sensibility and unable to negotiate the pitfalls of conversation, as inept and absurd when declaring his love or hesitant and struck dumb when unexpectedly meeting a friend after a long absence, and contrasts this with the great actor's sureness in rising to the occasion of every role by a controlled dissociation of the personality, which enables private experience to be translated into effective stage presence. For, as in his celebrated account of Mlle Clairon's performance in Racine's Britannicus, Diderot maintains that the great actress can, while apparently in the grip of her performance, through emotional self-control, 'so hear and see herself, judge herself and the impression she'll create', thus making her in this instance at once 'little Clairon and great Agrippina' (la petite Clairon et la grande Agrippine). ${ }^{3}$ 
In some respects Diderot's account of the actor's art anticipates the kind of dédoublement of experience often noted by the writers of a later generation, like Strindberg and Maupassant, whose Naturalism frequently evoked a division of consciousness wherein the writer 'seems to have two souls, one of which records, explains and comments upon every sensation of its neighbour, the natural soul, common to all men. ${ }^{4}$ What it certainly also does is to suggest an affinity between the role-playing of the actor and the divided consciousness of the autobiographer, seeing, hearing, and judging not only his past self but the effect his present narrative will have on its readers. Just as the autobiographer seems to possess a double consciousness of himself as he was in the unfolding sequence of his experiences and as he now is at the moment of recording them, so the actor can look on at the emotion he or she is producing on stage.

This in turn might well be linked to the idea of the actor or actress which emerged during the nineteenth century as someone essentially devoid of personality, as indeed a void or 'vacancy', the word used in Henry James's unjustly neglected novel The Tragic Muse, to describe the chameleon-like figure of the actress Miriam Rooth. 'What's rare in you,' Miriam is told by one of her admirers, Sherringham, 'is that you have - as I suspect, at least - no nature of your own... Your feigning may be honest, in the sense that your only feeling is your feigned one'. ${ }^{6}$ This is after he has concluded that 'the expression that came nearest to belonging to her... was the one that came nearest to being a blank an air of inanity when she forgot herself, watching something.'

In short, performers like Miriam are nothing in themselves, but merely who or what they pretend to be, a conclusion which the ultimately irremediably bourgeois Sherringham clearly finds disturbing:

It struck him abruptly that a woman whose only being was to 'make believe', to make believe that she had any and every being that you liked, that would serve a purpose, produce a certain effect, and whose identity resided in the continuity of her personations, so that she had no moral privacy, as he phrased it to himself, but lived in a high wind of exhibition, of figuration - such a woman was a kind of monster, in whom of necessity there would be nothing left to like, because there would be nothing to take hold of. ${ }^{8}$

Like much else in his fiction, James's study of the actress clearly owes a great deal to a French tradition in which the arguments of Diderot's Paradoxe, though rarely mentioned by name, remain an evident point of reference. By 1890 , when The Tragic Muse appeared, the idea of the actress as an impassive yet parasitically histrionic monster who preys upon the lives of those around her had become almost a commonplace. Edmond de Goncourt, for example, had deployed it in his anatomy of an actress, La Faustin, in 1882, by which time it had already been frequently exploited by Balzac in the Comédie humaine. If, 
on the one hand, this notion was closely related to many other male images of fin-de-siècle woman, as depicted in Munch, Zola, Wedekind, Huysmans and Mallarmé, it also echoed received ideas about the essential characterlessness of the writer, who is sometimes portrayed (by Balzac, Strindberg, and James himself) as a vampire, preying upon others as well as upon his own intimate life. Like the actor, the writer has a capacity for assuming or dissembling or 'representing' emotion which seems often to be allied with a characteristic coldness, or impassibilité, and his incarnations, too, subvert the idea of a fixed, inviolable selfhood and the moral order with which such stability is almost invariably associated.

Nevertheless, James might also have found his portrait of Miriam Rooth endorsed by the comments of Janet Achurch (the first professional English Nora in A Doll's House), who was reported by William Archer in Masks or Faces? (his 1888 riposte to Diderot's Paradoxe) as saying:

It is impossible for me to help it. Everything that comes, or ever has come, into my own life, or under my observation, I find myself utilizing, and in scenes of real personal suffering I have had an under-consciousness of taking mental notes all the time. It is not a pleasant feeling.

For it is, of course, Diderot who mounts a defence of what even the actress herself seems to have found dubious in her behaviour. Where Rousseau, in his Lettre à d'Alembert sur les spectacles of 1758, had inveighed against the actor's art on the grounds that to counterfeit, be inconstant, and prey upon others was immoral, Diderot regarded the variety of the great actor, with his ability, like Proteus, to assume a multiplicity of guises, in a positive light. 'The great actor is everything and nothing' (le grand comédien est tout ou n’est rien), he affirmed, in Le Paradoxe, and again:

It's been said that actors have no character because playing them all makes them lose the one that nature gave them, and that they become false, just as doctors, surgeons and butchers grow hard. I think people have taken the cause for the effect, and that they're only fitted to play all characters because they haven't one of their own. ${ }^{10}$

Once again the similarity with the Keatsian paradox in which it is precisely a lack of identity which characterizes the writer is clear: 'The poetic character,' Keats wrote, 'has no self... Not one word I ever utter can be taken for granted as an opinion growing out of my identical nature. ${ }^{11}$ But in the context of autobiographical writing this, like Diderot's paradox, assumes a peculiar resonance, and may cast doubt on traditional notions of the genre. For if, in playing all his different roles, the actor is nevertheless consistently himself, his ability to assume a multiplicity of identities makes him an exemplary instance 
of the multiplicité $d u$ moi which an autobiographer like Strindberg observes in himself and recognizes in others, and hence suggests a possible parallel between their respective role playing, and the paradoxical lack of identity which is often the final sum of the autobiographer's endeavours.

As Barret J. Mandel has observed, the major problems of autobiography as a genre usually arise from the unquestioned notion that a person's life is recoverable, that it is all somehow 'there' ready and waiting to be unearthed and transplanted. ${ }^{12}$ Moreover, it is also presupposed that the discourse in which the life is written is not a part of the life being recounted but a transparent medium through which that life can be seen. However, as St Augustine pointed out at the time of the genre's inception, 'with regard to the past, when this is reported correctly what is brought out from the memory is not the events themselves (these are already past) but words conceived from the images of those events.' ${ }^{13}$ These words are thus a translation and, though the life to which they refer may seem anterior to and outside the language in which it is recounted, the autobiographer's identity is constituted in the words he writes, which designate what is absent.

Autobiographical writing therefore entails alienation as well as identification. 'Je' is always 'un autre' since the remembered self with whom the writer identifies in the present (with whom the continuity of a perfect translation is claimed) is also a 'he' (or 'she'), the 'third party' of Beckett's supposedly fictional narrators, whose appearances are always put in 'by other parties' elsewhere, and whose unending story is told by 'another. ${ }^{14}$ Hence the paradox of the autobiographical narrator who is at once himself and yet not himself, continuous with his past and yet isolating that past in the act of writing about it, although like translation again, autobiographical discourse maintains the customary fiction of identity, of being a faithful rendering of a primary text.

It is, of course, Roland Barthes who drew attention to this dilemma in his essay 'To Write: An Intransitive Verb?': 'When a narrator (of a written text) recounts what has happened to him,' Barthes remarked, 'the $I$ who recounts is no longer the one that is recounted. ${ }^{15}$ Moreover, even this recounting 'I', the seemingly stable discursive ' $\mathrm{I}$ ' of the narrator who is telling the story now, is not the self who is writing to the present moment when this self is taken to be 'an interiority constituted previous to and outside language. ${ }^{16}$ But from the perspective of autobiography the situation has perhaps been most acutely illuminated by Freud in his analysis of Screen Memories, where he elaborates upon the inevitable rupture between the acting and the recollecting self:

In the majority of significant and in other respects unimpeachable childhood scenes the subject sees himself in the recollection as a child, with the knowledge that this child is himself: he sees this child, however, as an observer from outside the scene would see him.... Now it is evident 
that such a picture cannot be an exact repetition of the impression that was originally received. For the subject was then in the middle of the situation and was attending not to himself but to the external world. ${ }^{17}$

This is true of all writing, including even so immediate a transcription of experience into language as certain entries in the diaries of Anais Nin, where she sought the instantaneous capture of immediate experience 'before it is altered, changed by distance or time. ${ }^{18}$ But it clearly has a particular pathos in the case of autobiography, where the author claims to be the unique authority on the story he has to tell, and seeks to become his own progenitor. Confronted by the common patrimony of the language into which he is forced to translate himself, and which he inherits at birth, the autobiographer sometimes even speculates on the possibility of a means of utterance that is wholly his own what Rousseau identified as the need for 'a language as new as my project' (un langage aussi nouveau que mon projet $)^{19}$ if he was adequately to communicate his own singularity.

But as Roman Jakobsen has pointed out, 'In the realm of language, private property does not exist' (La propriété privé, dans le domaine du langage, ça n'existe pas) ${ }^{20}$. The language in which the autobiographer seeks to identify himself not only antecedes him; it is also held in common with other individuals as a shared circuit of exchange where he finds the available words already inhabited by the collectivity of speakers, of which he is only a single voice. Moreover, if the language at the autobiographer's disposal is embedded in the conventions of his time, beset by the contingent emphasis of the moment, and permeated by the social and intellectual inferences of the age, it is exactly through this continual search for self-definition that he seems to vanish into the text of which he is nominally the master, where he becomes not transparent, as Rousseau wished, but a property of the language into which he translates himself. Individual lived experience passes into language; it is mediated by the interrelationship between the signifiers, which stand in for the experience itself; they displace the past of the person they are nominally representing (and the notion of presence is ironically evoked by the faculty of language as representation, the fabrication of a copy that replaces the original); the empirical facts of the autobiographer's life are transformed into artefacts; sequence is endowed with meaning and condensed into design; and the writer becomes what for the reader he must remain, a figure of the text. For it is through the language to which he commits himself that the reader discovers the writer's identity; his self is actually formed under the eyes of the reader, in the latter's interpreting consciousness. Moreover, this written self emerges out of what Hume, in his reflections on personal identity in $A$ Treatise of Human Nature, terms the 'perpetual flux and movement' of an identity whose continuity we 'feign', ${ }^{21}$ and comprises a series of structuring choices 
and narrative strategies through which that self is composed. Further, every word employed to recover the traces of this buried past is also (like the tale which Alrik Lundstedt learns to tell about his past in Strindberg's novella, 'The Romantic Sexton on Rånö') a matter of covering them over again with words. It is an essentially formal rather than substantial identity, and, as Hume observed, 'all the nice and subtle questions concerning personal identity... are to be regarded rather as grammatical than as philosophical difficulties. ${ }^{22}$

The autobiographer is therefore confined to a life in language, according to criteria which are often sustained by the conventions of the alternative, dominant literary genre, the novel, where language is also employed to fabricate character and narrative likewise condenses a life into a destiny. As Lacan writes, of the analogous discourse of the patient in analysis: by recounting a past event

he has made it pass into the verbe, or more precisely, into the epos by which he brings back into present time the origins of his own person. He creates a kind of exemplary fiction, told by the imaginary self in order to defend its illusory sense of autonomy. And he does so in a language which allows his discourse to be understood by his contemporaries, and which furthermore presupposes their present discourse. ${ }^{23}$

But the origin of an autobiography is not the remote past which the autobiographer normally proceeds to investigate, and which conventionally forms the opening chapter of his story, but its end, namely the act of writing itself. As Mandel, again, writes: 'We experience our memories only in the present; it is the present moment which allows the past to exist for us, ${ }^{24}$ and as in the case of The Son of a Servant, the impulse to write an autobiography is frequently a response to present pressures rather than the allure of the past. Indeed, while it appears by definition to be concerned with the past, autobiography is in fact determined by the present, as a response to the moment in which it is written, and which is often everywhere present in the writing of a work that is its own conclusion. Hence it is tied to the vantage point from which the text of the past is being translated into the language of the present - the writer's past is in fact rooted in the present of its recall. It represents the writer's attempt to elucidate his present just as much as his past, even though a common strategy is for the autobiographer to write of himself as if he were dead. Thus Sartre sees his autobiography Les mots (Words) as his obituary, Hume calls his memoir 'this funeral oration of myself', and Darwin explains, in the preface to the autobiography he wrote for his family in 1876, how he had 'attempted to write the following account of myself, as if I were a dead man in another world looking back at my own life, ${ }^{25}$ while Strindberg also insists that his autobiographical fictions were written 'in the face of death' [inför döden, SV 20,376]. Nevertheless, the autobiographer creates his past 
rather than merely remembers it in the present, and in that respect his account is not something other than his life, not simply a secondary text into which he translates the primary text of his life, but an integral part of the life he is living and currently recording.

The problems raised by the medium in which the autobiographer seeks, like Rousseau, to convey 'moi, moi seul'26 are compounded by the recurring identifications, both literary and ideological, in the light of which he monitors and organizes his experience. For, as a genre, autobiography expresses what Hayden White has called 'the apparently universal need not only to narrate but to give to events an aspect of narrativity, ${ }^{\prime 27}$ and alongside the translation of the self into the general circuit of linguistic exchange, it is the teleology of narrative, which posits identity where there may he at best only a random contiguity, that endows the life of its subject with what Strindberg (in Fairhaven and Foulstrand, 1902) calls 'a sequence [or consequence] and order' [SV 50, 154]. It is in the generally chronological process of autobiographical story-telling, where a temporal sequence is elevated into a causal one through the seemingly continuous and uninterrupted enchainment of the text in which the writer inscribes himself, that the autobiographer shapes his life and overcomes the contingency and evanescence of experience. The latter, following what Hume calls the inveterate human predilection 'to suppose ourselves possessed of an invariable and uninterrupted existence thro' the whole course of our lives, ${ }^{28}$ takes on the attributes of a plot which confers a line of intention and a portent of design upon the data it is processing, and thus holds out the promise of a progress towards meaning. ${ }^{29}$ For the very act of narrating confers direction on the material which the text enchains, and allows the subject to place him or herself in the continuity of a story. Thus Ivar Lo-Johansson records the transition, at around the age of six or seven, from a time when memories were not yet enchained, and the past had not yet become a narrative composition, to a more consciously structured existence when he 'began with the help of memory like a kind of set of building bricks to form a whole out of more significant events that I had not previously bothered about... I consciously "composed" [författade] people and events and made a kind of poetry or sketches of them'. ${ }^{30}$

Moreover, the translation of the subject into narrative is itself part of the interpretative process, and is conducted according to the codes and conventions which allow the autobiographer to make his singular experience intelligible to his readers. These obviously entail what Georg Misch, in his A History of Autobiography in Antiquity, calls 'the different forms which the different periods provide the individual for his self-revelation and self-portrayal, ${ }^{31}$ and which, for a nineteenth-century writer like Strindberg, would include the discourses of the Bildungsroman, the roman intime, the case history, journal 
and confession. But they also encompass numerous more diffuse models, which in Strindberg's case include the structures of thought and feeling offered by what, in The Son of a Servant, he calls the 'quartet of Romanticism, Pietism, Realism and Naturalism' which prevented him from 'becoming anything but a patchwork' [SV 20, 72], the family romance of the patriarchal family, the constellation of the recurring image of himself in Biblical terms as 'the son of a humble cottage - The Son of a Servant - Hagar's' [XIV, 144], and the metaphors for recuperating experience provided by (among others) both Kierkegaard and Swedenborg as well as the multitude of mythical, Biblical and historical identities - Ahasverus, Asmodeus, Christ, The Flying Dutchman, Hercules, Jacob, Job, Jonah, Joseph, Merlin, Napoleon, Robert le Diable and Satan - in which he perceives some aspect of his experience incarnated, and which he employs to shape the written record of himself. Identity, as Strindberg recognizes in a letter to the Norwegian writer Bjørnson, in which he inventories his own 'old rat's nest of a soul, where shreds of antique Christianity, scraps of pagan art worship, shavings of pessimism, and shards of general world weariness are all jumbled together' [IV, 144; 1, 139], is adapted from a plurality of texts and structured within and around the discourses available to it at any one moment in time. Hence it also entails an ability on the autobiographer's part of being able to read and interpret his self, of discovering and decoding the language in which he or she is written. For, as Strindberg suggests, in the Preface to Miss Julie, the self is a 'split and vacillating' mosaic of previous and present periods of culture, 'scraps from books and papers, pieces of [different] people, torn scraps of fine clothes that have become rags' [SV 27, 105], an identity composed, in short, from the discursive formations and determinacies of an often lacunary unconscious.

In recuperating this identity it is not the writer's life as a succession of natural events that possesses meaning but the interpreted series into which it has been translated. The life is therefore a text to be read, interpreted and hence re-written, and this extended transposition of lived experience into a written narrative brings with it a recognition that a life may be as much a work of fiction - of guiding narrative structures - as the novels from which these are often taken. Hence Strindberg's remark, in a letter to Torsten Hedlund: 'It has been a characteristic of my life to assume the form of novels, without my rightly being able to say why' [XI, 224; 2, 557], and his delighted recognition, in a world so insistently shaped and designed by his own needs and desires, of plots and scenarios already imprinted upon the otherwise inchoate multiplicity of events in which he was both actor and spectator. Like Madame Bovary or Don Quixote, the autobiographer lives the set of stories he or she inherits and invents; they all organize experience to provide a configuration of significance through which life can be viewed and offer an available corpus of 
narratives whereby it can be interpreted and retrieved. In short, they allow the autobiographer to create himself. The autobiographer is his text, and as such constituted by the complex intertextuality of the discourses through which his identity is assembled.

Like a translation, therefore, an autobiography is always less, or other, than its original. Hence the dissatisfaction which many autobiographers, like Rousseau or Strindberg, seem to feel for the works which appear under their name, and which leads them to produce more than one account of a life which is, by definition, singular. Their repeated attempts upon their own lives, which suggest that no one version ever wholly accommodates the original, provide eloquent testimony to the fact that like a good translation, an autobiography may resemble its primary text but cannot reproduce it exactly. Indeed, an autobiography is always in one sense provisional, a prelude, since even when undertaken from a posthumous perspective, it does not include its author's death as an accomplished fact and an effective moment of closure, giving point even to a life cut off in mid career, as is generally the case with biography. Hence the manner in which autobiographical writing is often self-reflexive in a double sense: it is aware both of the self it is seeking to recover on the writer's behalf and of the terms of its own process. Indeed, many autobiographies reflect upon their own nature and provide a critique of the medium in which they are cast, although if they do raise doubts about the task in which the autobiographer is engaged, this often takes the form of a kind of concessio designed to validate his enterprise by recognizing its pitfalls and limitations. Thus, where the conventional notion of autobiography envisages its writer attaining 'a sense of perspective and integration' in a work that, as literature, 'achieves a satisfying

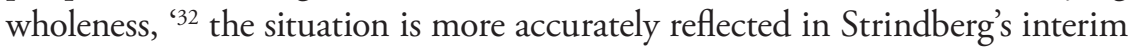
account of his life in The Son of a Servant, which ends, not with the customary climax of an identity discovered and sealed in writing, but in the paradoxical recognition of his textual multiplicity, recoverable (if at all) in the totality of all his writing:

But the result, the summing-up, one asks. Where is the truth for which he sought? It lies here and there in the thousands of published pages, search them out, put them together and see if they can be summed up; see if they remain relevant for more than a year, five years. Consider whether they even have a chance of being relevant, when that demands recognition by a majority. And don't forget that the truth cannot be found, because like everything else it is in a state of constant becoming (utveckling) [SV 21, 215].

The autobiographer is condemned to the multiplicity of becoming rather than the singleness of being. His account resists the static dimension of singular definition that it may initially have been devised to satisfy, and raises the 
possibility that the autobiographer will lose or rather, like Strindberg, disperse himself the more he multiplies that self in words. 'Making yourself all up again for the millionth time,' as one of the voices in Beckett's That Time expresses it. ${ }^{33}$

However, while identity may be forever deferred in the play of the text, in mastering its inscription the writer-subject is somehow distinct from the chronology he calls his life while nevertheless adding to it, again in a double sense: what he writes supplements what he has lived and yet is an event in the life he is recounting. In this, as someone who is his own spectator, he resembles Diderot's actor, at once his own subject and object, the player and first audience of his many roles. Surrounded by all his numerous autobiographical texts, it is this that Strindberg has in mind when he tells Leopold Littmansson that he 'can see myself objectively, something the he-and-she asses and colts call my subjectivity, as if that were something bad' [X, 350; 2, 524]. So can the actor, which is why (like the autobiographer) he is at once morally suspect and dangerously creative. As Sherringham responds to Miriam's question 'And do you think I've no character?' - 'Delightful being, you've got a hundred!' ${ }^{4}$ 


\section{Life Plots and Letters}

Peter Brooks begins his valuable study of narrative, Reading for the Plot, by pointing to the way in which 'we live immersed in narrative, recounting and reassessing the meaning of our past actions, anticipating the outcome of our future projects, situating ourselves at the intersection of several stories not yet completed'.' With no Oedipal allusion intended, this study echoes Brooks and takes place at the intersection of the three roads of inquiry alluded to in the title.

The first of these, 'life', points towards the past. It refers to the way in which a writer orders and recovers his or her lived experience in the form of autobiography. The second, 'plots', concerns itself with how the writer (and more particularly the nineteenth-century dramatist) confers significance upon his material by means of plot as a way of organizing and interpreting the world. The third aspect, 'letters', acknowledges the emphasis which Strindberg customarily placed on letter writing as a model for writing in general. As he outlines the rudiments of this aesthetic with disarming simplicity in a letter to his sister Elisabeth, in 1882:

If your heart is full and you cannot speak, then write! Every educated person can write, that is, commit their thoughts to paper. You can write letters; a good and true book is a letter. Writing is not inventing, making up something that has never happened; to write is to relate what one has lived. Anyone who relates what he has lived is a writer and serves his fellow men by telling them about what may occur in life. [III, 41; 1, 97]

Characteristically, too, the epistolary form will concern itself with the life of its writer, following the dual need that Strindberg feels for self-expression, on the one hand, and the ordering, or plotting, of experience, on the other. Moreover, given the sheer abundance of his correspondence (as Kerstin Dahlbäck observes, the letters are, in this respect at least, Strindberg's principal genre), ${ }^{2}$ and taking into account the concern that Strindberg frequently expressed in his correspondence about the significance of the various plots, both sinister and literary, which he discerned in his life, the letters are clearly fundamental to these two earlier preoccupations. Indeed, in his letters Strindberg may be apprehended as the obsessive reader as well as writer of his life. 
Although far more complex an issue than is generally recognized, the autobiographical element in Strindberg's writing is clearly crucial. Towards the end of his career, he himself privileged a series of his works in different genres as the basis for a continuous and authoritative account of his life, to be called The Son of a Servant. The sequence was to include not only the four volumes with that general title, written in 1885-86, but - in chronological order of the life recalled - the novels A Madman's Defence (1887), The Cloister (written 1898 but not published until 1966), ${ }^{3}$ Inferno (1897), Legends (1898) and Alone (1903), the Occult Diary he kept between February 1896 and 11 November 1908, and his collected correspondence. ${ }^{4}$ Moreover, as in this letter to Elisabeth, he frequently implied that writing involved only the more or less direct transcription of lived experience into words, even if he does go on to concede that 'to relate is not merely to place events in sequence; one must also have something to say with the narrative, throw light on an aspect of life. The art of the writer lies in ordering his many impressions, memories and experiences, in leaving out the unimportant things and giving prominence to the main ones' [III, 41; I, 97]. Consequently, in Strindberg's case, criticism has not been slow to elide all difference between the writer and his text by mapping what has been written neatly back onto what is known of the life he lived, and then to read the unstable compound of the text as established fact rather than fiction, whereas here, as in the work or other Romantic and postRomantic writers from Goethe to, for example, Claude Simon, there is in fact a ceaseless tension between reference and fiction in both autobiographical and imaginative discourses.

Nevertheless, like Rousseau, with whom he has a great deal in common, Strindberg demonstrates a persistent personal desire to discover and reveal himself in writing, a desire which is fostered by his early Pietism and endorsed by a combination of other impulses derived from the discourses of Kierkegaard, Naturalism and contemporary psychology. Moreover, he consistently entrusts himself to writing in preference to speech because (again like Rousseau) that is the medium in which, unmolested by others, he may forge an identity and control his destiny. Both The Son of a Servant and the Confessions demonstrate how, without writing, identity is undermined and fretted away by the summary conception which others mistakenly form of their authors, mistakes which speech, however truthful, is unable to dispel. In place of the treacherous impermanence of the spoken word in which the speaker is dissipated, both men resort to writing in order to re-appropriate the sense of themselves which eludes them in their spoken intercourse with other people.

In part this doubtless stems from what Strindberg, with one eye on a Darwinism that he otherwise distrusts, calls 'the instinct for differentiation, to be no one but oneself' [VII, 247; 1, 304]. Almost by definition autobiography 
seeks to establish its author's singularity and predicates the authenticity of its discourse on the grounds that the autobiographer has a uniquely privileged insight into the details of the life in question. 'We know no more than one life, our own' [SV 20, 373], Strindberg insists in the 'Interview' originally designed to accompany the first volume of The Son of a Servant, and that is one's right and proper subject when, by the same token, no one else can know it. Hence the claim, often made in justification of autobiography, and especially by autobiographers, that the person who has lived a life is the one best able to re-tell it. And hence, too, the authority it is seen to possess as a primary text. For even though an autobiography always remains secondary, in the sense that it necessarily (or ostensibly) retraces the life its subject has already lived, the autobiographer is engaged upon a project in which he becomes, by writing, the author of his own life, a kind of self-progenitor whose account of himself takes precedence over all others and the authority to which all later accounts usually refer. Indeed, confronted by the common patrimony of the language into which they are forced to translate themselves when they write this account (a language they share with their readers and critics) autobiographers sometimes speculate on the possibility of a form of utterance that is unique and personal to themselves. Thus, Rousseau felt the need for 'a language as new as my project, ${ }^{5}$ and his role as the model autobiographer is perhaps nowhere more apparent than in this desire to secede from a common, shared discourse and inaugurate his own.

However, what happens in practice is something else. The text affords its author only a temporary refuge, and the identity he or she is seeking to establish or maintain is forever deferred and unstable, thus prompting the compulsive autobiographer (Strindberg, Rousseau, Stendhal, Leiris or Ivar LoJohansson) continually to multiply the texts in which this elusive singularity is sought. Indeed, in his continual search for self-definition, the autobiographer seems regularly to disappear into the text of which he is nominally the master. As his intimate, lived experience passes into language, it is mediated by the inter-relationship between the signifiers, which come in time to stand for the lived experience. And as language displaces the past and the person it is employed to represent, as it creates the facsimile which replaces the original, it establishes a metaphorical narrative which secretes and accretes meanings in a framework that subsumes the particles of autobiographical detail implanted in it. Private experience enters the public domain of language and then the formal contract of a literary genre, where it is enhanced with conceptual figures and stylistic devices as an item in the literary institution and able in turn to foster other discourses - like the one that is developing here. It is the signifier which moves into the foreground. The empirical facts of the life are transformed into artefacts, sequence is endowed with meaning and condensed into design, and 
the autobiographical act of exhibiting oneself in public remains what it has always been, a metaphor. The autobiographer remains behind that discourse that he or she leaves after him, and becomes a figure of the text. Or as Derrida remarks, in his essay 'The Purveyor of Truth':

Exhibiting, baring, stripping down, unveiling - this is an old routine: the metaphor of truth, which is as much as to say the metaphor of metaphor, the truth of truth, the truth of metaphor. ${ }^{6}$

If by using language the autobiographer places himself within the common patrimony he shares with his fellow speakers, he also employs it to relate a narrative or plot a drama in which the roles, though seemingly personal, are to some extent already scripted and cast. If autobiography represents in a particularly acute form what Hayden White calls 'the apparently universal need not only to narrate but to give to events an aspect of narrativity', the way in which the single life may be shaped or plotted, and the roles in which the writer may recover himself, are culturally as well as personally determined, according to models which, until recently, the autobiographer was most likely to discover in other books. It is hardly surprising that Rousseau, for example, dates the unbroken consciousness of his own existence from the time of his earliest reading. Reading offers a template against which the autobiographer may measure his personal experience. Although there is a danger that the plots he follows may distort experience, confer a spurious authority upon it, or come between the writer and what may be deemed to have taken place, it is to some degree a question of inserting oneself into what seems the most appropriate of available plots, of reading one's experience in the light of existing models in which, however indistinctly, it is possible to discern what Peter Brooks terms 'a line of intention and a portent of design that hold the promise of progress toward meaning.' ${ }^{8}$ Indeed, as The Son of a Servant and Inferno, those two compounds of Strindberg's multifarious reading, amply demonstrate, even a title has the ability to intend much of what follows.

In fact Strindberg was obsessed by plots and plotting. Perhaps the fundamental question which preoccupied him throughout his life concerned the nature of the plot in which he was embroiled, or whether, indeed, there was one, and not merely a random accumulation of encounters and events, particles of experience without form or meaning. For what disturbs him is the sight of any blank, plotless space - of, for example, the empty seascape, so different from the cluttered profusion of the Stockholm archipelago, off Luc-sur-mer at which he gazed in horror in 1885 (a true horror vacui) and which, as Gunnar Brandell has suggested, '? helped precipitate his experiment with atheism - or any white, unsignifying sheet of paper upon which no sign of authorial life has been inscribed. Hence, too, his failure ever entirely to abandon representational 
painting, as he seemed frequently to be on the verge of doing, to omit, for example, the lonely poisonous mushroom clinging tenaciously to the bottom right hand corner of the painting of that name, from $1893 .{ }^{10}$

However, after the demise of the patriarchal family romance into which he saw himself born (and which, in many respects, he spent a lifetime seeking to reconstitute), and following the failure of the Pietist scenario in which he sought to locate himself during his early years, one is compelled to recognize that this attempt to live without a script according to the possibility that, as he puts it in The Son of a Servant, 'everything was simply jumbled up with one thing piled on top of another, the laws of chance and necessary whims and no plan to creation' (SS 19, 244), was an extended period of crisis no less crucial than the more notorious events of the Inferno period during the mid-1890s when he discovered the designing hand of an omnipotent experimental artist in nature and concluded that it was presumably this same artist in providence who managed the deeper syntax of his own experience in what now appeared to him to be the stage-managed events of his unfolding life. It was now, too, when Strindberg began to erase still further the boundary between life and art, and dream and waking experience, and to interpret the interface between his subjectivity and the world about him according to a type of free associational technique, that he indulged in the most insistent speculation on the identity of the author of the script in which he featured, as well as (no New Critic, he) upon the nature of this author's intentions. 'Who stages these events for us, and to what end?' he wondered, in a letter to his friend Axel Herrlin in 1898 [XII, $273 ; 2,622]$, in which he pondered the significance of recent events in both their lives. At times he attributed an active role to himself, as when he claimed to have 'put his entire life on stage in order to become a dramatist'; ${ }^{11}$ at others he regarded himself more as a character: 'The whole of my life often seems to me to have been put on stage so that I might both suffer and portray it'. And sometimes, as in the following entry in the Occult Diary during January 1901, he quite simply cannot decide where the boundary between art and life, or author and character, lies:

Have been reflecting on my life: is it possible that all the terrible things I've experienced have been staged for me to enable me to become a dramatist and portray all kinds of mental states and possible situations? I was a dramatist at twenty. But if my life had passed quietly by, I should have had nothing to write about. ${ }^{12}$

The last of these reflections only reaffirms a tendency to see the world in terms of literature which Strindberg displayed throughout his life. Not only does he suggest that a turbulent personal experience is a necessary precondition for the value of what a writer produces; he also habitually regards any event as 
already essentially either a scene in a drama or an episode from a novel. Life, in fact, imitates literature rather than vice versa; it has a natural propensity to assume literary form, and the writer's task is largely a case of recognizing the genre inherent in the material. Thus he informs his sister Elisabeth that her 'life has at least three periods - childhood, youth (with step-mother) and your experiences out in the world' [Ill, 41; 1, 97], while in the 1894 Vivisection 'La Genese d'une Aspasie' he describes how an experienced writer initiates a novice in the rudiments of his craft:

Having moved into the same house, the master devoted himself to giving the poor wretch a thorough education, getting him to narrate the story of his life, showing him where the profitable motifs lay. 'That is a drama,' he instructed him; 'there's a short story, and there a novel.' [V, 22; SE, 93]

Significantly, the starting point both in the Vivisection and the letter remains the course of the writer's own life; it is from there that one begins. But like the vampires of his later texts, like Zachris in Black Banners (1904) and Hummel in The Ghost Sonata (1907), Strindberg did not draw back from speculating in other people's experiences as well. Although he reacted strongly against the possibility of being caught up in someone else's plot himself (note his outraged reading of both The Wild Duck and Hedda Gabler in which he thought he recognized a bowdlerized version of himself in Hjalmar Ekdal and Eilert Løvborg respectively), he had no such scruples about utilizing what he observed in others. Witness, for example, the delight with which he viewed the events surrounding the figure of the Norwegian pianist and writer Dagny Juel, his original Aspasia, in 1893. 'Oh, it's a novel! She lays waste families and men, compels men of talent to embezzle money, to leave house and home, their duty and careers' [IX, 188; 2, 456], he exclaims enthusiastically as he records her impact on their mutual acquaintances at the tavern he christened 'Zum schwarzen Ferkel' in Berlin, where she was introduced by the painter Edvard Munch, after having already enchanted Strindberg's young scientist colleague, Bengt Lidforss, somewhat earlier in Sweden, and where, following a brief intermezzo with Strindberg himself, she eventually married the fin-de-siècle Polish writer Stanislaw Przybyszewski. Moreover, as she passes between the male members of the Ferkel circle (or is passed around - the sexual politics of this episode are highly ambiguous and deeply compromising to someone who, like Strindberg, was clear that any initiative had to be masculine), Strindberg finds the same kind of formal satisfaction in the course of these events, as they occur, that he will one day take in structuring several of his later dramas in the form of a circle, much as Schnitzler will do in his celebrated sexual merry-goround, Reigen, in 1900. For here, as in part one of To Damascus or the partial recapitulation of this period in his life in Crimes and Crimes, the first and final 
scenes echo each other: 'This ending satisfies me completely', he tells another of the actors in this drama, Bengt Lidforss: 'Chap. I: Munch-Juel in the Ferkel... Chap. XII: Munch-Juel in the Ferkel... (End!?)' [IX, 347]

Not that the dramatist in him does not feel drawn to intervene, however. A few days later, on 10 January 1894, he suggests that Przybyszewski should revenge himself on Juel by having her arrested as a prostitute: 'Poland ought to take care of that Aspasia business himself, as the married man's revenge! A policeman - a cab, the Rathaus, then the courts - and so: off with her head!' [IX, 357]. As a dénouement he finds this so attractive that he employs it himself against the demi-mondaine Henriette in Act Four of Crimes and Crimes, written some five years later, in 1899.

Life, then, can be read like fiction, one watches it unfold 'just like when reading a novel or watching a play' (alldeles som vid romanläsning eller åseendet av en pjäs [SV 50, 248]), and the conventions governing the two domains are in many respects the same. As he wrote, in 1901, to his daughter Kerstin, who had, or so he maintained, 'led me through Inferno as my Beatrice, by way of gorge and path of lamentation, through anguished nights and evil days':

All plays contain changes of scene, and changes of dramatis personae too, but in the last act, they all reappear, and the author mustn't forget a single one of them. Such is the eternal law of drama, and of life! And woe to him who forgets it! So now you know! [XIV, 41; 2, 675-6]

On the one hand, he is seeking here to excuse his failure to respond to his young daughter's most recent letter ('Forgive me, but I was ill with fever when your last dear picture arrived. Do you think I could ever forget you, you who led me through Inferno...' [XIV, 41; 2, 675-6]). On the other, he is describing the dramaturgy employed that same year in the play that himself thought most warmly of, A Dream Play.

The question therefore arises to what extent Strindberg did in fact stagemanage his life. Certainly, as a writer who drew heavily and copiously upon the primary capital of his own experience, there is a frequent need to replenish his otherwise rapidly depleted stock of ready material. 'Better, however, an unhappy marriage than none at all. One goes through it and comes away more experienced than before, and experience is capital', the entrepreneur Smartman declares at the close of Black Banners [SV 57, 219], and Strindberg, too, evidently considered the events he sometimes instigated in all three of his marriages as capital (kapital) to be translated into chapters (kapitel).

This is also the case with the Inferno crisis, the turbulent and (melo) dramatic period through which he effected his passage from the naturalist texts of the late 1880s to the incipient modernism of the late 1890s and early 1900s. These years in Berlin, Austria and Paris, during which he largely 
abandoned belles lettres and devoted himself to a variety of alternative activities, including his painting and alchemy, may reasonably be regarded as in certain respects a skilfully crafted and dramatically effective peripeteia in the middle of his career. Throughout the Inferno period, it is evident that Strindberg is reviewing his experiences with a mind to publication. In May 1896, for example, he is intent on producing what he describes as a 'book about all that I have "seen" and experienced since last December' [XI, 193; 2, 554]. And however alarming these experiences are there is no doubt, as he monitors them in his correspondence (and most particularly in the letters addressed to the theosophist Torsten Hedlund at Göteborgs Handels- och Sjöfartstidning) that he continues to function as an author, accustomed to publishing an account of his experiences on a market that is often as capricious and enigmatic as the script of the unfolding events he is seeking to decipher. On one level, the central phase of the Inferno period is inaugurated as a business project in which Strindberg secures a period of relative financial stability that will enable him to conduct the experiments with the data of his own life that form the basis of Inferno. For with the help of Hedlund in Sweden, he receives a privately donated sum of 1,200 kronor, paid to him in monthly instalments and even, on occasion, directly to the locations where the Parisian scenes in the drama of his life are being acted out - the Hôtel Orfila and Mme Charlotte's Crémerie in the rue de la Grande Chaumière [XI, 135-8]. As surety, he offers various promises of future writing:

I abandoned literature in order to escape being superficial; but no one, least of all I, escapes his destiny. I shall, however, try, and suggest this consortium as follows: that I write a series of letters directly from memory and my notes, without a thought for the paper and its readers, but so that every letter will form a chapter in a future book, which, if you like it, I then offer you, and for no honorarium unless it promises to bring in something. [XI, 138; 2, 547-8]

Traces of this plan remain in the letters Strindberg wrote to Hedlund between 6 and 22 July 1896 on manuscript paper paginated consecutively from 1-59 across the intervals of their composition and despatch. They evidently encompass a provisional attempt to organize some of the material later incorporated in the early chapters of his autobiographical novel. (Compare, for example, the opening paragraph of the letter dated 7 July 1896 [XI, 245; 2, 568] with chapter one of the novel.) Furthermore, having abandoned himself to the events of the Inferno period, he knows precisely when it is opportune 'to re-establish contact with life' [XI, 310] in order to resume the potentially profitable exploitation of his experiences in literature. In fact both the beginning and the end of this phase of his life demonstrate a remarkable combination of self-awareness and business acumen. The letter from Austria in which he re- 
opens epistolatory contact with Hedlund was written immediately before his move to Paris, one day (23 July 1894) after he had informed the most intimate recipient of his Austrian correspondence, his old friend Leopold Littmansson, that he didn't 'know what fate now holds in store for me, but I feel "The Hand of the Lord" poised above me. A change is in the offing, upwards, or straight down to the centre of the earth, who knows about such things!' [X, 152; 2, 487], and he followed it with another in which he referred to his urgent need for 'raw material, observations, preferably my own, because I cannot depend on other people's' [X, 206-7; 2, 501]. Becalmed in his literary career, he requires fresh impulses and identifies Hedlund as a likely means to his literary and personal renewal. However, having primed what did in fact turn out to be an effective avenue to the material support that his undertaking required, he was equally astute, some four years later, in recognizing when the vein he was exploiting had been exhausted. 'My religious struggles are over and the whole Inferno saga at an end,' he told his current literary editor, Gustaf af Geijerstam, in March 1898 [XII, 271; 2, 621-2]. It was now time to write for the theatre again.

A detailed study of this extended act in Strindberg's life would need to consider his choice of settings carefully, of how the locations where the different scenes of the Inferno drama are played out have been admirably selected in order to enhance the action long before they are used as the backdrop for Inferno or To Damascus. There is a dramatics of place in Strindberg which he exploits in life as well as in literature. Zum Schwarzen Ferkel in Berlin, Dornach and Klam in Austria, the Hôpital Saint-Louis and the Hôtel Orfila as well as the Jardin des Plantes and the Luxembourg Gardens in Paris and the small town atmosphere of Lund all provide the fitting scenery for the events enacted in each of them well before these events are written up in literary form. Indeed, in retrospect Strindberg characteristically implies this even as he suggests that the skilful plot of his unfolding life derives from another source. 'I am compelled to admire the refined skill which has selected this place for my prison,' he writes of Lund at the beginning of Legends [SS 28, 211], where he relishes the irony that brings him to the town at precisely this moment in his career, a middle-aged man who ought to have more in common with the professors there than with the students who welcome him, a déclassé intellectual who is praised by these students just when he has himself jettisoned the radical ideas with which they associate him, and become their opponent: 'This is rather neatly arranged, and as a dramatist I have to admire the fine composition of this tragicomedy. Truly, a well-made scene' [SS 28, 213].

But perhaps of equal significance to the way in which Strindberg contrives a suitable mise en scène for each act of his life is the fact that each stage of his career can generally be associated with a specific correspondent. A shift of 
direction, a change of outlook, is almost invariably accompanied, as with the transfer of his correspondence from Littmansson to Hedlund, by the opening and closing of a major sequence of letters. 'Why have I written all this now?' he wonders, in one of his first letters to the up-and-coming Swedish writer, Verner von Heidenstam: 'Perhaps because I felt the need to clarify my present position before embarking on an important new epoch in my life' [V, 111; 1, 189]. In fact, the backbone of his correspondence, at least until after the Inferno crisis, is made up of a number of these often suddenly commenced and abruptly terminated sequences in which he keeps his chosen correspondent informed about selected aspects of his life with almost daily reports, each letter taking up the tale even as it is unfolding. Moreover, in some cases such as the letters to Pehr Staaff in 1887 in which he vivisects his relationship with Siri von Essen and charts the disintegration of their marriage, it is clear that he is discovering, or inventing or recomposing this life in the very act of writing about it. It is as if he allows the words to have their say, unleashes them on a line of speculation, and follows where they care to take him in what is effectively a trial run for the text they conjure up, the autobiographical fiction $A$ Madman's Defence, which he wrote later that year.

Given the emphasis which Strindberg placed on letter writing as a model for writing in general, for example in the extended epistle on writing which initiates his correspondence with Siri von Essen [I, 186-96; 1, 36-43], his own letters are obviously of particular relevance to a project in which the boundaries between the different discourses he employs seem to dissolve into the single unremitting activity of writing. Nor is it surprising that he always conceived of them as an essential part of his work, particularly of that unwieldy collection of autobiographical texts that he wished to see published in one volume as 'The Son of a Servant'. For in offering what appears to be the possibility of a true multiplicité $d u$ moi in terms of the different aspects and projections each correspondent may elicit, the letters represent perhaps the ideal method of self-representation if, as Strindberg frequently points out, character is not singular but several, not one but multiple, not fixed and substantial but a fluid coalescence of numerous and varied texts - those 'conglomerations from various stages of culture, past and present, scraps from books and newspapers, bits and pieces of different people, shreds torn from fine clothes that have become rags, patched together just like a human soul' of which he writes in the Preface to Miss Julie [SV 27, 105]. However, although Strindberg frequently uses an extended sequence of letters as a kind of mirror in which to observe and analyse himself, his correspondence in practice often resembles a monologue rather than the dialogue normally evoked by an exchange of letters. Indeed, in telling Eugène Fahlstedt, his fellow student at Uppsala, 'I don't expect an answer to this letter. For there isn't one' [I, 122; 1, 26] or in pointing out to 
the Norwegian novelist Jonas Lie that, 'You don't need to answer all the letters I shall sometimes bombard you with. I simply ask to be allowed to deposit them in your escritoire as documents, which you may take out in my defence when I am vilified before a larger public than the Swedish' [IV, 180; 1, 143], he acknowledges that his correspondence is sometimes not primarily intended to provoke a full and reciprocal communication.

At its most intense, this practice produces a form of externalized inner monologue, a type of public self-address in which Strindberg contemplates his situation and inspects himself. In a succession of correspondences, he deftly secures a balance between intimacy and distance which permits him to concentrate upon himself. Thus, in the crucial stages of the Inferno crisis, he uses Torsten Hedlund as a screen onto which he projects his inner turmoil in order to interpret it. The similarity with the relationship between analyst and analysand is striking; so, too, is a parallel with the almost contemporary situation contrived by Freud in relation to his friend Wilhelm Fliess through which, largely by letter, he conducted his extraordinary self-analysis. Both Freud and Strindberg cast their correspondents as the distant intimates of their intellectual isolation, largely uncomprehending blank screens designed to receive what each of them extracted from themselves by experiment, introspection and free association and then transferred to paper: 'Read what I write without criticism, without resistance, and don't prevent me from running on,' he tells Hedlund, in 1896, 'for I am growing as I write this, and maybe you will too' [XI, 240; 2, 567]. However, what Hedlund was expressly forbidden to do was to place his own constructions on the material with which Strindberg supplied him. As always, the latter resisted other interpretations of his own story. He refused the transference, and when Hedlund became too intimate, he broke off the relationship in a letter which confirms the one-sided nature of their correspondence: 'Your appearance in my life always seemed to me like a mission, and your person, which I do not know and have never seen, always remained an abstraction to me... [now] your role in my life [seems] to be played out' [XI, 393; 2, 600].

Note how Hedlund is allotted a role and becomes a figure in the drama of Strindberg's life. The latter had used Hedlund, whom he never met, whose age, even, he badly mistook, believing him to be some twenty years younger than in fact he was, as the more or less silent witness of the unfolding story of his life, a blank page on which he traces and retraces its possible plot. These letters have many other functions. They solicit information, afford moments of catharsis, act as substitutes for conversation, allow Strindberg to experiment with different points of view. But their prime impulse is the emplotment of his life, its induction into narrative and drama. And while their abundance and immediacy may suggest that the pulse of life is closer to the surface here than 
in the extended composition of his novels and plays, it would be a mistake to assume that Strindberg inevitably reveals himself more openly in them than elsewhere. They, too, are already secondary to the experience he exploits, experience which may itself be being lived with literature in mind. As Richard Ellmann remarks, at the outset of his biography of Joyce, 'the life of an artist... differs from the lives of other persons in that its events are becoming artistic sources even as they command his present attention'. ${ }^{13}$ But in Strindberg's case, as in Joyce's, this need not be regarded, as it so often is, as a damaging failure to transcend experience and abandon himself to art. Rather, he was so overwhelmingly responsive to the claims of art that he could not leave the raw material of life untreated. It was as if everything he encountered, all that he experienced, had to be brought into stories or focused and placed in dramatic form. Like Alrik Lundstedt, the artistic hero of his novella 'The Romantic Organist on Rånö' (1888), Strindberg remained uneasy until he had found some form or formula to accommodate what he had seen, felt and heard. Only then - and the word recurs frequently in this context throughout his life - was he momentarily calm (lugn).

In this respect, he emerges as the antithesis of his close contemporary, Chekhov. In his plays Chekhov expends a great deal of artistry on establishing a radical difference between life and art. Thus, for example, in the consummately crafted third act of Three Sisters Masha, having just confessed her love for Vershinin, the man who simply chanced across her path in Act I, remarks: 'What's going to become of us? When you read a novel, everything in it seems so old and obvious but when you fall in love yourself, you suddenly discover that you don't really know anything, and you've got to make your own decisions.' ${ }^{14}$ Likewise, in the final act of The Seagull her namesake also stresses the futility of considering her hopeless love for Trepliov in literary terms: 'All this is just nonsense. Love without hope - it only happens in novels. ${ }^{15}$ For Chekhov there is no plot, no underlying pattern, no script to rehearse in life, where every effect obediently follows from its cause and where every event unrolls as it must, coherent in every detail, as it does in art. Which does not mean that experience is random, simply that, as he states:

the things that happen on stage [should] be just as complex and yet just as simple as they are in life. For instance, people are having a meal at the table, just having a meal, but at the same time their happiness is being created, or their lives are being smashed up. ${ }^{16}$

However, the point that Chekhov makes, with great insistence, is precisely the absence of any direct correlation between the lives people live and those undertaken by the characters encountered in books. Like Don Quixote and Emma Bovary, his Soliony in Three Sisters, who apes the behaviour of 
Lermontov's heroes, demonstrates the folly of any such close reading when he kills Toozenbach in a duel. Where, in Strindberg, a character's experiences naturally fall into literary shape, Chekhov uses literature to make a point of undermining such identifications. To Sasha, for example, in his early play Ivanov, the protagonist is a Hamlet figure, a superior man to be worshipped or redeemed; to Dr Lvov, however, he is a Tartuffe, a man both selfish and hypocritical. But Chekhov's point, as he indicated in a letter about the play, is that there are many Ivanovs. He is a most ordinary man, not a literary hero at all.

Strindberg, on the other hand, is always acting a role, playing a part, seeing himself and those about him as the figures in scenarios derived from literature and myth. Even those texts nominally termed Naturalist reveal a definite literary or mythical deep structure, evoke the presence, in the lineaments of their characters, of previous incarnations. Where Miss Julie is concerned, for example, the complex intertextuality of her identity is extended by the range of associations that she and Jean bear. Not only are they the swineherd and princess of fairy tale but Actaeon and Diana (the name of Julie's thoroughbred dog which mates with the gatekeeper's mutt and prefigures her own fall as the Nöjd episode foreshadows the principal action of The Father), Joseph and Potiphar's Wife and - even more ominously - Adam and Eve. As Jean makes plain, in the long, seductive speech to Julie with which the first phase of the play approaches its climax, the Count's estate represents the Garden of Paradise where young boys not only scrump apples but also dream of possessing beautiful young girls, and the play as a whole, in which Julie steps down from her elevated position into the mire of human sexual relations, is a re-run of the Fall of Man. The patriarchal Count whose 'unhappy spirit hover(s) above and behind it all' [SV 27, 109] is thus an Old Testament deity, kept artfully offstage but of whose omnipresence an audience remains aware through the ever-present riding boots that Jean has to polish, the bell at which he cringes, and the speaking tube via which, at the end of the play, he announces himself from on high to the fallen couple on stage.

In The Father, meanwhile, the Captain and Laura play the roles of Hercules and Omphale and Agamemnon and Clytemnestra, and it is therefore no wonder that in the frequently quoted letter about the play which Strindberg addressed to Axel Lundegård on 12 November 1887 he should complain of being unable to distinguish between waking and sleeping, of how his 'life and writing have got all jumbled up' and he is unable to tell 'if The Father is a work of literature or if my life has been' [VI, 298; 1, 255]. What he has achieved by this intermingling of life and fiction greatly resembles the conclusion of Pirandello's play Six Characters in Search of an Author in which the boundary between art and life, or madness and sanity, and illusion and reality has been 
deliberately blurred, and the spectator cannot determine whether the young girl and boy in the drama are dead or only acting.

And yet, is this so extraordinary? Is what Strindberg makes of his life in terms of literature the impure and sullied art that it is sometimes claimed to be? As Roman Jakobsen observed, in his reflections on the death of Mayakovsky, in the essay 'On a Generation that Squandered its Poets': 'Is there any one of us who doesn't share the impression that the poet's volumes are a kind of scenario in which he plays out the story of his life? The poet is the principal character, and subordinate parts are also included; but the performers for these later roles are recruited as the action develops and to the extent that the plot requires them. The plot has been laid down ahead of time right down to the details of the dénouement. ${ }^{17}$ 


\title{
4. History and His-Story
}

\author{
What is History then? \\ Providence, accident, irony, or Fate? \\ Turgenev, to Pauline Viardot, \\ 15 May 1848
}

History and His-story: a fortuitous verbal association perhaps, but they both figure prominently in Strindberg's work and are closely linked at various points and in different ways throughout his career. From Greece in Decline in 1869 and Master Olof in 1872 via the two-volume history of The Swedish People of 1880-82, the four volumes of short stories on historical subjects that he wrote in the 1880s and 1900s, to the eleven major plays on Swedish historical themes written in the decade between 1899 and 1909 and the three 'worldhistorical plays' written in 1903 - the past of Sweden and (especially in his later years) the history of the world were, like his own past, one of Strindberg's most constant preoccupations throughout his life, a life that he assiduously documented as an item in the annals of his own times. "Why rake up the past?', Queen Maria Eleonora asks in his most ambitious history play, Gustav Adolf (1900). 'Because the past rises up' (Därför att det förflutna står upp [SS 32, 232]), replies the king, echoing numerous such comments to do with repetition, recurrence and the return of the past in several of Strindberg's more evidently personal dramas. 'Everything repeats itself [Allt går igen, SV 44, 69]: the web of past actions with its entangled plot of guilt and suffering in which the protagonist is caught up returns to haunt the present, whether it is the present that Gustav Adolf inherits from his predecessors in the House of Vasa; the past that comes increasingly to dominate the present of the protagonist in (for example) To Damascus, The Dance of Death, and The Burned House; or the material underlying any of the accounts of his own past that accumulate as Strindberg lives on.

Given the numerous ways in which the genres of autobiography and history were readily associated during the nineteenth century, this link is hardly surprising. Conventionally, both historian and autobiographer regarded the past as a series of events that required 'emplotting' by way of narrative into an order or sequence whereby that past would be rendered intelligible to the 
reader. Neither historian nor autobiographer generally regarded the way in which the narrative was told as unduly problematic, and certainly not in the problematic mnemonics of the self and its representation that have evolved over the last one hundred years. One merely began at the beginning and continued until the end, observing in the process the linear, chronological unfolding of the subject in time, whether that subject was personal, national, or universal in scope. If misgivings arose, it was mainly in so far as the facts on which the respective accounts were based might be considered 'right' or 'wrong'

Thus history, during what Hayden White has called its 'mature' or 'classic' phase, lasting from around 1830 to 1870 , was widely regarded as dedicated to the objective pursuit of truth. ${ }^{1}$ Given the salient documents judiciously used, it might produce an accurate picture of the past that would disclose the formal coherence of man's life in time. What eventually underpinned this faith was not, however, the order or disorder of the available archives. Rather, it was a conviction shared by the historian with a majority of those who produced extended narratives, both fictional and factual and with which the century abounded, that this data could be represented in language as a story. Indeed, the paradigm for the writing of history or biography is still in many respects provided by those narrative conventions established for the nineteenth-century novel by Scott and Balzac, for whom fiction was always so deeply engaged with history, both past and present, and by whom the individual life was invariably portrayed as in complex interaction with the social existence of the period in which it was lived.

It is therefore perhaps worth noting at the outset a certain curiosity in the apparent confidence that Strindberg retained in history as an unfolding source of emplotted meaning, even after the Inferno crisis, when, as a dramatist, he was otherwise engaged in dismantling the dependence of drama on conventional plot-making. In this context, both the attempt in his essay 'The Mysticism of World History' $(1903)^{2}$ to arrive at a synthesis of historical events conceived as story and the very writing of history plays on into the present century appear passé; on this account at least, Strindberg would seem to be at odds with a standpoint that is common in a great deal of modern writing, in which - as once again Hayden White has remarked ${ }^{3}$-history is regarded with suspicion and often with despair (a view shared, for example, by James Joyce's Stephen Daedelus, who famously regarded history as a nightmare; by Nietzsche, with his feeling for the way in which the historical sense paralyses action and turns men into shades and abstractions; by Ibsen, whose Hedda Gabler suffers from a surfeit of history in the guise of the abstracted Tesman; and even perhaps by George Eliot, whose Dorothea exchanges history, in the form of Casaubon, for art, in the person of Will Ladislaw). There seems, in short, something of a contradiction between the modernist writer who created $A$ Dream Play and The 
Ghost Sonata, and the tenacious pursuer of order and meaning in the events of history, in which the latter is conceived (in 'The Mysticism of World History') as still retaining the vestiges of some sacred masterplot - 'The Conscious will discovered in world history,' as he calls it in his correspondence [XIV, 244], which establishes the framework through which the world is organized and explained.

Perhaps, however, this apparent faith in history reflects a desire on Strindberg's part for the past to make sense, for in that case maybe his own life would too. Here, as regards autobiography, the issue is more complex. Certainly, the assumption at the heart of much nineteenth-century autobiographical writing was that it had likewise to do with the faithful, if more subjective, reconstruction of past events in their proper order and significance, a sequence that, if once established, would yield a definitive account of the life in question precisely because of the authority its teller could claim on his or her own behalf. This, of course, was a strategy that Strindberg employed in the programmatic interview that he wrote to introduce the first volume of The Son of a Servant:

How is one to know what goes on in other peoples' minds; how can one know the complicated motives behind someone else's actions; how can one know what they said in an intimate moment? Well, one invents... one knows only one life, one's own. [SV 20,373]

By definition, of course, autobiography - like history - comes after the event it records and, in the act of writing, it also constitutes its subject by applying to it various strategies of linguistic recuperation and many of the rhetorical devices of literature. Moreover, in the process of sifting through, and selecting from, lived experience, autobiography, too, renders the past as an interpreted expanse of time that is endowed with a fuller sense of meaning precisely by its reproduction as narrative. What Strindberg is claiming here, however, and it is a claim that numerous other autobiographers (including, for example, Edward Gibbon and Rétif de la Bretonne) have also put forward, is nothing less than the idea of his privileged access to the past he has lived as at once the subject and the object of the tale he has to tell. It is also an extremely neat way of defending the presumption that any man could be the author of his own life.

This tale, moreover, this story that he tells, is his history. It is hard, indeed well-nigh impossible, to keep these two words apart. Certainly Strindberg could not. For him History (except - and importantly - in parts of The Swedish People) was always a narrative - a story, or Geschichte as he described it in a letter he sent his German translator, Emil Schering, just prior to writing 'The Mysticism of World History', in which, after 'a rapid read through', he judged the course of world history to be 'a picaresque novel' [SS 54, 378]. But no more can the reader of The Son of a Servant readily distinguish history 
from story, particularly when confronted by a title page that announces ' $E$ n själs utvecklingshistoria 1849-67' (what the English translation, by Evert Sprinchorn, calls 'The Story of the Evolution of a Human Being'). ${ }^{4}$ For as this subtitle suggests, this story is part of history ('historia') and the evolution of the serving woman's son unfolds in the course of a specified historical period. Furthermore, of all Strindberg's autobiographical fictions, The Son of a Servant, with its sense of how the growth of the self is to be seen as part of a never-ceasing interplay with a developing world, comes closest to the classic works in the genre, which, as Karl Weintraub has pointed out, 'took on its full dimension and richness... [as] part of that great intellectual revolution marked by the emergence of the particular modern form of historical mindedness we call historism or historicism'. For Weintraub, whose concept of the dynamic relationship between the individual subject and the historical world underlies this 'historicized' approach to autobiography, the key work is Goethe's Dichtung und Wahrheit (Poetry and Truth, 1811-31) with its prefatory claim that the principle task of [auto]biography is to present a man in the conditions of his time, thus making it a matter of moment precisely when a man is born since - as Goethe writes - 'it can truthfully be said that any man, had he been born a mere ten years earlier or later might as far as his own formation and his outward achievement; are concerned, have become an entirely different person'. ${ }^{6}$ And just to confirm that he means what he writes, Goethe pointedly informs the reader in his opening sentence not only of the year, but of the month, day, and very hour at which he was born- as the clock struck twelve on 28 August 1749 .

In discussing The Son of a Servant with Gustaf af Geijerstam Strindberg himself regards the work as an "evolved" [utvecklad] form of the naturalist novel including historical, psychological, and social material' [V, 295; 1, 195]. Writing to Edvard Brandes with an easy use of the Swedish 'historia' to describe both history and story, he describes the book as

... the history of the epoch in one man's life... There will be five volumes, that is the whole story 1849-86. It will be the story of Sweden, the story of the making of a writer; the story of the origin and evolution of a soul during a particular period, the story of the nature and causes of the present culture sickness. Etc. [V, 339; 1, 202]

And again, he says (of the first volume):

It contains a full biography of a well-known and important writer with as little falsehood as the genre allows, and a domestic history of Sweden 49-67. The book will therefore help young people make sense of the immediate past without which it is impossible to understand the present $[\mathrm{V}, 314 ; 1,197]$. 
But this narrative doubles as a further item in the natural history of the human heart, to which Strindberg once told Siri von Essen all writing of value belonged [I, 198; 1, 43], and offers itself, moreover, as another contribution to the 'study of man' which Rousseau, in reflecting upon his Confessions (1781-88), saw as only just then beginning. In this respect, too, The Son of a Servant is conventional in its point of departure, even though its premises are offered more as a document humain in the archives of history and contemporary medical science than as a personal contribution to that library of autobiographical and confessional material which Herder had called for in his 'Von Erkennen und Empfinden der menschlichen Seele' (1792), but from which it is only a short step to the idea that Strindberg shared with Taine, namely, that if the conduct and thought of an individual was determined by the historical moment, the moment was itself illuminated by the various literary manifestations of an individual life to a far greater extent than by the kind of documents on which history customarily relied. As Taine observed, in the celebrated introduction to his Histoire de la littérature anglaise (1863):

I would give fifty volumes of charters and a hundred volumes of state papers for the memoirs of Cellini, the epistles of St Paul, the table-talk of Luther, or the comedies of Aristophanes.

However, Strindberg, in acting as his own historian in The Son of a Servant (perhaps more nearly his own natural historian) does more than merely present us in Johan with an account of his historical self - as distinct, that is from his writing self, August, and in contrast to the figure of 'Axel' with whom, in both novels and plays, he otherwise shares his experience during much of the 1880s. As the final volume makes plain, the book, like such other accounts of his own life as Inferno (1897) and even Alone (1903), is a response to a particular crisis in his life. In general, Strindberg turns to autobiography in extremis, when he is (imaginatively or in fact) 'confronting death' (inför döden) [SV 20, 376], as a means of establishing precisely where he is at the point of writing, and in order to make what seems like, but never entirely is, of course, a fresh beginning. In fact The Son of a Servant marks perhaps as crucial a moment in Strindberg's life as Inferno does; as he makes plain, it is written at least in part as a response to that sudden sense of apparent plotlessness induced in him by his encounter with scientific Darwinism and the atheism he associated with it, a world that seemed to him to be 'all just a higgledy-piggledy jumble of regulated chance and necessary caprice and in no way a planned creation' [SS 19, 244], a world represented - if it can be called that - by the empty, unsignifying space at which he gazed from the North Sea coast at Luc-sur-mer in Normandy in 1885 , with its horizon void of the rocks and islands by which his eye was accustomed to plot a course in the Stockholm archipelago. 
One of the main casualties of this experience was a belief in history as a meaningful sequence of events, a belief that had already been undermined by Strindberg's encounter some years previously with Eduard von Hartmann's pessimistic Philosophie des Unbewußten (Philosophy of the Unconscious, 1869). 'When he looked at life, and particularly at the course of history, he discovered only a series of circles and the repetition of delusions,' he remarks in The Son of a Servant on the impact that von Hartmann, whom he had helped his friend Anton Stuxberg translate into Swedish, had made on him. Now, when examining the evidence for evolution at the moment of writing in 1886, he again sees change, but no meaningful progress or development towards a discernible goal; rather, the image on which he falls back, the notion of a 'kretsgång', or circular motion, that he originally derives from Der Kreislauf des Lebens (1852) by the Dutch-Italian physiologist Jakob Moleschott (1822-93), whose theory of the random circulation of matter Strindberg claims to have encountered when he was only fifteen, once again suggests some pointless stasis or flux of being, rather than the coherence afforded by sequence and succession. ${ }^{8}$

And yet, having negotiated the horror vacui that consumes his hero Axel Borg at the close of By the Open Sea, and following the free fall of his own Inferno crisis, it becomes clear that it is partly history that provides Strindberg with at least a temporary means of recreating order in his life when he returns to literature at the end of the 1890s. Against the void or existential horror of the plotless moment, he places history, what the narrator of Graham Swift's novel Waterland calls 'the Grand Narrative', whereby man fills the vacuum he detects about him and dispels his own private fears (Swift's narrator, incidentally, is a historian and should perhaps know better). Man lives, he goes on, by telling stories:

... only animals live entirely in the Here and Now. Only nature knows neither memory nor history. But man - let me offer you a definition - is the story-telling animal. Wherever he goes he wants to leave behind not a chaotic wake, not an empty space, but the comforting marker-buoys and trail-signs of stories.?

Without narrative, without being the instigator and/or subject of a plot or story one is - as Scherherazade would find herself - dead, or at best given over to that endless, monotonous addition of day tacked on to day, which is the experience of Samuel Beckett's later protagonists (and even they tell stories). Moreover, history, which reduces men to characters and the complex past to events, and which, having happened, resembles nothing so much in its unfolding as a play (both Hegel and Kierkegaard agree on this, if on little else), offers one of the models of coherence whereby Strindberg recuperates his life; it provides him 
with a variety of plots and scenarios through which he reads the past not only of nations but of his own present life.

Not, of course, that this was something entirely unique to the post-Inferno period. If, in the stories of Swedish Destinies and Adventures that he wrote on and off between 1882 and 1890 Strindberg had, as he told the publisher Claes Looström, 'as always taken the warp from my own life' [VII, 154], so in the historical dramas, as he wrote, some twenty years later, of The Earl of Bjälbo (1909), he had 'made the principal characters live by taking blood and nerves out of my own life so that they became mine and are my own property' [SS 50, 298]. The partial disguise of history was in any case an option he sometimes adopted, as in Tschandala (1889) in which recent events too close for comfort in his own life with his family at Skovlyst in Denmark were dressed up in seventeenth-century costume, or in stories like 'A Witch' (En häxa) and 'Development' (Uveckling), in which he explored his own deeply personal conflicts at a historical remove. 'You must read a story called 'Development' in Vol. 2 of Swedish Destinies,' he urged Jonas Lie, in 1884, 'There you have me in 2 parts!' [IV, 194; 1, 147]. Even Master Olof he could call his 'biography' - in one of those disarming statements with which he sometimes appears to collapse the fictional into the autobiographical [IV, 165].

However, while it would be quite possible at this point to indulge in the pursuit of a series of more or less conceivable correlations between Strindberg and his fictional characters it is, rather, the way in which history offers him a series of plots or scenarios through which he establishes the contours of his life, even as he is living it, that is of real interest here - how, firstly, the stage of history affords a parallel series of fates, figurations of plot, and patterns of relationship, in which he continuously seeks to read his own life and locate himself, and then how - as something already composed and 'staged' - history resembles nothing so much as a play 'put on stage' (satt i scen) for him to contemplate, as indeed, in his later years, he often felt his own life to have been. In this respect, one may discern a neat community of interest between the working dramatist, accustomed in his history plays to dealing with finished lives and events that unfolded long ago, and the image of the drama dramatum in Kierkegaard's Concluding Unscientific Postscript of 1846, which, in offering Strindberg a view of the stage of history as one where God is the sole spectator, partly underlies his many late comments on the seeming theatricality of his own life. 'But world-history,' Kierkegaard writes,

is the royal stage where God is spectator, because he is not accidentally the only spectator, because he is the only one who can see. To this theatre no existing being has access. If he imagines himself a spectator here, he merely forgets that he is an actor... who must leave it to the royal spectator and actor how he will use him in the royal drama, drama dramatum..$^{10}$ 
Strindberg acknowledges the self-conscious theatricality of the history play as always to some extent a variation on a known theme by stressing the element of play, role play and performance in many of his later works, particularly Erik XIV (1899), Kristina (1901) and Gustav III (1902), while the enigma presented by the seeming theatricality of his own life emerges in his recurring speculations on the identity and purpose of the dramatist in whose plot he finds himself. As he asks himself in the Occult Diary (24 January 1901): 'Who stages these performances for us, and to what end.... Is it possible that all the terrible things I have experienced have been staged for me?'

Indeed, there is an unresolved but dramatically productive confusion as to who is the real dramatist in Strindberg's work, a confusion that dates back at least to Miss Julie and Creditors in 1888. However, before clarifying this confusion, it is worth pointing out that the nature of life as theatre is something on which Strindberg reflects in his later history plays as well as in relation to his own experience. Consider, for example, the way in which the once poorly regarded Gustav III operates both as a history play that focuses upon a series of events near the close of the reign of the historical Gustav III and as a dramatic meditation on history, more especially upon history as theatre. It is in fact impossible not to regard the self-reflexive nature of Gustav III, which comments both on its own nature as a play and on the theatricality of history itself, as central to its meaning and stage effect. And to achieve this ambiguity, Strindberg naturally exploits the fact that as a monarch his king was besotted with the theatre, himself a playwright given - or so Strindberg suggests - to extending his obsession with drama onto the stage of history, which he approaches in terms of the history plays of which he was so fond. Thus Gustav's decision to assume Dalecarlian costume in Act Two allows Strindberg to collapse the one into the other, since Gustav plans not only to don the attire and thereby take on the role of his heroic predecessor Gustav Vasa, but also, as it were, to take a leaf out of his own opera libretto on the subject, one written by the historical Gustav III in collaboration with the poet Johan Henrik Kellgren (1751-95), and first performed in 1786.

Moreover, as Matthew Wikander has pointed out, in his valuable study of historical drama from Shakespeare to Brecht, The Play of Truth and State, there is a further complex pattern of historical and theatrical allusion woven into the text of Gustav III through its many references to Caesar (both Shakespeare's and history's) and Caesar Augustus (once again both in terms of history and as a theatrical figure in Corneille's drama Cinna). Having once 'played Brutus and overthrown these homespun Caesars' [SV 48, 232], Gustav now finds himself cast in the role of Caesar. 'Oh, great Caesar, beware the Ides of March' [SV 48, 265], Fru Schröderheim says to him, theatrically attired in the costume of the fury Megaera, in Act Four, and when he congratulates himself on being 
'born with a caul and with Caesar's luck', the Queen responds by observing: 'Caesar's luck... wasn't there someone called Brutus?' [SV 48, 300]. At that moment the face of his future assassin, Anckarström, is glimpsed through an upstage window while the King, who recognizes an effective curtain line when he hears one, brings the play to a conclusion by repeating it with enthusiasm: '"Wasn't there someone called Brutus?" - That's superb! - Superb, Madam!' [SV 48, 301].

But Caesar is not Gustav's only role. He makes his dramatic entry to the conspirators at Huvudsta in Act Three quoting Corneille: 'Soyons amis, Cinna, c'est moi qui t'en convie' [SV 48, 249], a role that is later confirmed when the poet Bellman, having been addressed by the King as 'Horatius', responds by calling him 'Augustus' [SV 48, 268]. The implication in this pattern of allusions is, of course, that just as Shakespeare or Corneille followed history in writing their plays, so history, in the person of Gustav III, is to some extent rehearsing the theatrical scripts these dramatists have made of history. Moreover, this aspect of the play is compounded by the way in which Gustav is first seen as a playwright managing events and manipulating men, stage-managing as it were the cast of players at his disposal ('[he] has written a new play, with a leading role for you... very décolleté, Fru Schröderheim is told [SV 48, 228]), and then as an actor, forced to perform his role in a script he neither controls nor understands. The two are neatly combined in a crucial exchange with Armfelt about the developing intrigue in Act Two:

ARMFELT: That's not badly constructed, considered as a play!

THE KING: Who knows, perhaps it is a play, all of it!

ARMFELT: But the last act, have you got that?

THE KING: That will come of itself! [SV 48, 238]

In this anticipation of the end, as in the closing pages of the play, where Gustav is stalked by Anckerström, Strindberg creates one of his most theatrical effects because he can rely (at least in Scandinavia) on an audience knowing what in fact happened to Gustav III in history, while at the same time he impresses upon the spectator the irony of this 'endgame' situation in which (as in Beckett's play), a parallel is drawn between chess, play and theatre, between history and a game in which we are both player and pawn - or king and queen. Thus, 'Gustav, the player-king spends his final moments on stage moving in and out of danger in a way that specifically, visually, suggests the final moves of a game of chess. Anckarström's face at the window reminds us that the last move, which we will not see staged, must be checkmate.' ${ }^{11}$

However, so far as Strindberg's insertion of himself into the plot of history is concerned, what becomes evident is that while he may on occasion refer to one of his historical characters as representing his 'biography', he does so 
primarily in terms of what that figure's life may yield as a structuring device, an item in the available symbolic system of his culture that will enable him, through the teleology of plot, to transform the plotless flux of experience into the enduring substance of a text. It is not any simple identity between himself and Olof or Gustav Vasa or Erik XIV that he is after, but the possibility that, by matching his experience against theirs, by placing the puzzling scenario of his still problematic life against the one they have already lived, he will be able, as it were, to read his own story in their history.

Plots, whether in the novel or on stage, condense a life into a destiny, and autobiographers frequently date an unbroken consciousness of themselves to their earliest reading. According to Les mots, the young Sartre, for example, found pleasure and relief from the contingency of experience in the plot summaries of the plays and novels he found listed in Larousse, and in Book One of the Confessions Rousseau even dates his sense of continuous selfhood to the discovery, in both his mother's small library and in his grandfather's, of other exemplary plots by means of which he could create a kind of specular image of himself through identification and reverie. In Plutarch's Lives, for example, he discovered a number of models for the 'republican' author of the two Discours of 1750 that he would subsequently become.

In a sense this is what Strindberg does with history, although even Master Olof represents not so much an ego ideal that he is in search of as an attempt to trace what correlation there may be, if any, between his own experience and the trials that someone else has undergone. The same is also true of several other historical figures (Gustav Vasa, for example, King Magnus in The Saga of the Folkungs (1899) or - among his contemporaries - Alfred Dreyfus). But one sometimes detects a particular sense of satisfaction when the eye of the professional dramatist recognizes such turns of event in his future career as seem to confirm the plot with which he identified himself as a young man, a young man who had, as he maintains in Inferno, foreseen his fate at twenty, 'when I wrote my play Master Olof, which has shown itself to be the tragedy of my life' [SV 37, 293].

However, the 'emplotment' of his life in terms of history begins well before Strindberg starts to write either plays or stories on historical subjects. For just as his correspondence reveals him as ever alert to the way in which contemporary events constitute themselves naturally as literature in the form of novels, stories, or dramas, so in his letters he likewise catches their drift in parallels with history. Thus, long before he writes Carl XII (Charles XII, 1901) - even before he embarks upon a study of this Yeatsian anti-self in the story 'At the Wake in Tistedalen' (1891) - he uses the figure of the king he otherwise calls 'the great criminal' to map out his own situation, as when, in 1888, he writes to Verner von Heidenstam from Skovlyst in Denmark: 'I've pitched my 
Bender here and await a Narva or a Fredrikshald, in order to make my entry into Sweden' [VII, 87; 1, 276 - the allusions are to Karl XII's victory over Peter the Great at Narva, his five-year exile at Bender in Bessarabia, and his death at Fredrikshald in Norway]. Similarly, before he contemplates writing Gustav Adolf with its setting in the Thirty Years War, he explores his relationship with his Austrian relatives in historical terms, as a conflict between Catholic and Protestant, or uses the Uhl family to spin an elaborate web of parallel events between his own fate and that of Napoleon. ${ }^{12}$

It may seem a major step from such allusions to history in the letters, which are, it must be admitted, partly playful, to the larger structures of the later history plays. And yet what is at issue in both cases is a possible correspondence between the text of history and his own experience. Swedish history as a whole or in its constituent parts such as the Vasa Saga or the Saga of the Folkungs, offers him a canvas of some seven and a half centuries through which to explore the possibility of a causal pattern amidst the complex detail of sometimes apparently chaotic and discontinuous events. It is a considerable block of time - far exceeding the individual life he had explored in The Son of a Servant-in which he can try out the scenarios of guilt and suffering, nemesis, crime and punishment that he had previously examined in the context of his own life.

Some plays - Gustav Vasa, Gustav Adolf, even The Saga of the Folkungs yield these patterns of meaning quite readily. The 'miracle story' aspect of Gustav Vasa's life, for example, is one on which Strindberg himself comments: 'how God led him out of Danish captivity up to Dalarna, and how, after many dangers, he finally freed his country from bondage' [SV 41, 163]. The parallel with his own experience, as recounted in Inferno, To Damascus and elsewhere, is there to be made as one of several networks of allusion, including the Biblical and mythological, that suggest the existence of a suprahuman providential order in the affairs of men and nations, both past and (therefore) present. Other plays - Erik XIV and Carl XII, for example - seem to yield no such ready structure. Indeed, the former has been seen (by Michael Kaufman) as an ironic critique of traditional nineteenth-century historicism in its scepticism about coherent designs in history and modern precisely in its sense of the 'discontinuous, fragmented and chaotic, where the only principles of order inhere in the mind of the individual perceiver... a history stripped of all illusions of providential order, [and] emptied of teleology or regeneration. ${ }^{13}$ Although it is probably more correct to say that the spectator is not supposed to regard this disorder as necessarily inherent in history but as lying in the inability of the blind and unbelieving participants in the events depicted to perceive their purpose, the dramatic thrust is, nevertheless, to portray the protagonists as grotesque figures passively borne by forces they can neither control nor understand, the playthings of chance, like the limp doll on which the action of Erik XIVhinges 
Strindberg, however, may have it both ways, for, as always, the dramatist can explore the possibilities inherent in different standpoints. On the one hand, there is a world in which everything adds up, as in Gustav Vasa; on the other, a world in which the characters suffer a bewildering series of reversals and come out at a loss. But as in the naturalist plays, in which he sought to examine 'the raw, cynical spectacle that life offers' [my italics, SV 27, 102] on the supposition that there was no recognized divine masterplot, the disturbing question still remains: who is the scriptwriter? Who, if anyone, writes the plot, whether of history as a whole, or of an individual life?

For the period following the Inferno crisis, the answer would seem to be straightforward. Or at least, Strindberg offers two very clear and ready replies. In a discussion of Shakespeare's Julius Caesar, he declares that 'History in the large is Providence's own composition' [SS 50, 114], while in 'The Mysticism of World History' he maintains that synchronicity is the distinguishing feature of a world governed by order and design as opposed to disorder and chance. Thus, in both Crimes and Crimes (1899) or To Damascus on the one hand, and Gustav Vasa or Erik XIV on the other, the meaningful order of the emplotted scenes predicates the ordering presence of a master playwright, whether the protagonists can see this or not. ${ }^{14}$ As Strindberg explains, to his old friend Leopold Littmansson, regarding the structure of Crimes and Crimes: 'The dénouement! Yes, you see, the hero of my play, the plot master, is the Invisible One (God)' [XIII, 120].

However, this standpoint does not hold for long, even as regards the history plays, and the positions adopted by the mature Naturalist and the ageing Providentialist ultimately complement each other. With Miss Julie, for whom existence is 'a scum that drifts, drifts, across the water, until it sinks' [SV 27, 135], the very notion of a plotted life was placed in doubt. And yet, only a few weeks later, when he wrote Creditors, the insistent question concerning who in fact is directing the intrigue in the play, who (in the absence of God) conducts the audit, dispenses justice, and balances the accounts in a dramatic structure that is itself the perfectly balanced vehicle of the intrigue it depicts. Thus when, at the end of the play, Tekla accuses her ex-husband, Gustaf, of harbouring 'a villainous plan to destroy my happiness', he replies by rejecting any idea of a plot in both the literary and the secret or underhanded senses of the word. Things merely turned out as circumstance and situation ordained. He chanced to see her on a steamer; Adolf, her new husband, provoked him by recalling the book in which she had branded him an idiot; and even when he was confronted by her return, in Scene Two of the play, he declares that 'I didn't really know what I was going to say!' At which point he adds, 'Like a chess player, I had a number of possible plans, but which one I used depended on the moves you made. One thing led to another; chance played a part; and so I had you ditched' [my italics - SV 27, 267]. 
Chance, maybe, and a game of chess, but in practice the result is highly theatrical, artificial even, in the patterned, formal arrangement of the three dialogues which go to make up a play that is characterized by an acute sense of the way in which people assume and exchange roles in the interplay of life. And it is this interplay that invites comparison with that second set of history plays, written between 1901-02, in which there is a shift from the Providentialist model informing Gustav Vasa and Erik XIV to one based upon the notion, advanced in 'The Mysticism of World History', that history is 'an enormous game of chess played by a single player who moves both black and white, takes when he ought to, makes plans for both sides, is for himself and against himself, thinks everything out in advance and has only one aim: to maintain balance and justice, while ending the match in a draw' [my italics SS 54, 353; SE 191].

Here, Strindberg's attempt at plotting a relationship between his historical protagonist and history in order to illuminate his own experience has failed, or, rather, it has taken on something of the modernist hue that originally seemed to be lacking in his treatment of history at the time. When Martin Lamm first took issue with the Scribean elements of Gustav III or saw in Strindberg's portrait of Queen Kristina only a bohemian cabaret artiste, he for once missed the point, not only of the elaborate political game that is being enacted in both plays, but also with regard to their metatheatrical dimension - the almost Pirandellian consciousness they have of themselves as plays, as theatre. Moreover, it is a consciousness that is also implicit in the structure and situation of Creditors. Gustav, the royal dramatist and actor; Karl XII, the marionette; and Kristina, the actress queen - all, like Gustaf the vivisector of Creditors, enact roles, play games, or are played with, and thus invite comparison with their author, the indefatigable intrigant Strindberg, for whom art habitually evokes notions of 'lek', or play. 'Thus Providence plays with those who would play Providence', says Arvid Horn, of Karl XII [SV 4 7, 139]. But he who plays 'providence' here as in any other of these plays, is Strindberg himself. Ultimately, the attempt to read his life in the fortunes of historical figures fails. Nevertheless, he finally shares his life with them in the game of art. And thus, as Emerson observed, in a passage from his essay on history that Strindberg had surely read: 'All history becomes subjective; in other words, there is properly no history, only biography'. ${ }^{15}$ 



\section{5. 'P-aris': Note for an Unwritten Volume of Strindberg's Autobiography}

It is frequently assumed that by the end of 1894 Strindberg had turned away from literature and entered upon the period of scientific and alchemical experiment that accompanied the early phases of his Inferno crisis, that period of intense self-scrutiny, experiment, mental and spiritual turmoil and, ultimately, self-renewal that led to his re-emergence as a writer with Inferno in 1897 and To Damascus in 1898. However, this notion needs to be treated with some circumspection. As is so often the case with Strindberg, it is a view that originates with, and is fostered by, the author himself. As he informed $L e$ Temps, in 14 January 1895: 'At the moment I am returning to science, which I have never completely forsaken; but I am now going to devote myself to it and nothing else', while fifteen months later he continued to maintain, this time in Le Gaulois of 4 April 1896: 'I am entirely devoted to chemistry and botany. That is quite enough for me. Literature no longer interests me in the slightest.' Yet it is doubtful if Strindberg's neglect of literature was in fact as absolute as he suggests here. While his interest was certainly subdued during most of 1895 , it is evident from his letters, especially those to Torsten Hedlund in Gothenburg during 1895-6, that he was all the time considering the exploitation of his experiences in terms of literature. As Sven Delblanc has suggested, the Inferno crisis needs to be seen 'as an active rather than a passive process: Strindberg does not undergo a process of reshaping, rather he chooses in a magnificent, half-unconscious act of will an outlook on life that is morally meaningful and aesthetically fruitful'.' The question, as Strindberg was again the first to point out, was to find an adequate form for the experiences to which he opened himself during these years, and there were to be many stages on the way to his re-entry into literature.

One of these is to be found in a page of notes, hitherto (1979) unnoticed, in carton fifteen of Nordiska Museets Strindbergsarkivalia in the Royal Library in Stockholm. On the reverse of a series of chemical formulae headed 'Camphère $\mathrm{C}_{20} \mathrm{H}_{16}$ ' $[\mathrm{SgNM} 15: 5,23]$, in which Strindberg confirms to his own satisfaction his old supposition 'that chlorine is a hydrogen peroxide', are a series of entries, with the general title 'P-aris', which may, for a number of 
reasons, be considered Strindberg's very first attempt to come to terms with the early stages of his Inferno experiences. The notes, written on a folio sheet of Strindberg's customary Lessebo bikupa paper (watermark 1893) can be quite precisely dated, both by the nature of the subject matter and by their handwriting, to the end of January 1895. Indeed, it is the handwriting that is most immediately striking. Strindberg's usually neat, clear calligraphy is replaced here by an untidy and in places hardly legible script that suggests it was written only with considerable difficulty. And while the text itself is not specific, a reference in the notes to 'the Hospital' (Hospitalet), as well as a comparison with other examples of Strindberg's handwriting from the first weeks of 1895, suggest that these notes originate from the time when he was undergoing treatment for psoriasis in the Hôpital de Saint-Louis - a period he eventually describes in chapter one of Inferno.

There is thus an overlap between the period covered by these notes and the text of Inferno, although the bulk of their preoccupations is weighted on the first months of Strindberg's stay in Paris, immediately after his arrival there from Austria in August 1894. These preoccupations are the familiar ones of his journalism during the second half of 1894 and the first month of 1895, but the notes indicate an attempt to précis the events of this period in an effort to organize his experiences and determine their underlying pattern. For this reason it seems reasonable to dismiss the idea that they were intended merely as a continuation of his experimental prose study 'Sensations détraquées', which Strindberg considered undertaking in a letter to his current French translator, Georges Loiseau, on 23 January that year: 'Un pressentiment d'un jour prochain paralyse mon interêt de continuer. C'est dommage parce que je finirais si joliment ici à Saint Louis, plein de sensations sublimes, et comme battu après mes tentatives infertiles d'assiéger la grande ville, de Versailles, des hauteurs du Panthéon, du Montmartre, etc.' $[\mathrm{X}, 376] .^{2}$ They envisage far too elaborate a synthesis and are, moreover, too realistic in intention to be a fourth section of what, in a letter to the painter Richard Bergh, he called this 'symbolist-détraqué compromise with the poetry of science and madness' [X, 278]. Instead they retrace an entire phase, the first stage of which is identified with 'Ver-sailles' (again with the curious but characteristic hyphen, as in the title, 'P-aris'), where he originally stayed at the home of his old friend of the 1870s, Leopold Littmansson, on his arrival in the city. (The son of the cantor in the Jewish community in Stockholm, Littmansson had been the addressee of the important sequence of thirty-five, often extremely long letters in which Strindberg had explored his state of mind and intellectual holdings between June and August 1894, and had lived in Versailles for more than a decade, since his marriage to a wealthy Frenchwoman.) The notes end with the last entry to which a specific date can be set - the reference to 'Forges-les-Bains', 
where Strindberg seems briefly to have considered resuming his life with his second wife, Frida Uhl, who was currently living with their daughter at one of her parents' houses in Austria. 'In Forges-les-Bains two hours from Paris one can rent a three-roomed house with kitchen, reasonably furnished, for 300 Francs a year' [X, 368], he wrote to Frida around the middle of January 1895. Between these two points, in a column of more or less elaborately plotted items, Strindberg covers many of the familiar landmarks of his writing on Paris both at this time and afterwards, in Inferno, Legends, and Crimes and Crimes.

One group of names, for example, envisages a cab ride from the station at St Lazare, taking in the fashionable boulevards, the Bois de Boulogne and the Trocadero, including the neighbourhood of Passy where Strindberg stayed in a flat in the rue de Ranelagh during September 1894, courtesy of the confidence trickster Willy Pedersen (alias Grétor, 1868-1923). A speculator in forged paintings, Grétor acted as the somewhat dubious impresario for the painting in which Strindberg was engaged at this time. ${ }^{3}$ The conception recalls similar urban journeys in Jacob Wrestles and Alone in which the landscape of the city is employed to structure the narrator's feelings and direct his associations.

A second cluster of locations includes the carp pond in the Luxembourg Gardens ('I love the Jardin de Luxembourg and its carps', Strindberg wrote to Frida, in November 1894 [X, 291; 2, 515]), the Panthéon, Cluny and Notre Dame, as well as a reference to 'De la croix', which does not indicate which picture, if any, Strindberg had in mind although in all probability he is thinking of Delacroix' mural of Jacob Wrestling with the Angel in the Church of Saint-Suplice, a painting to which he returned not only in the fragment Jacob Wrestles in 1898 but also in several other of his post-Inferno works.

The sequence concludes with a series of allusions to the 'Invasions Barbare' and 'the Normans' (Normandera), and to the polemical standpoint of his article 'Le Barbare à Paris', which was published in Gil Blas in September 1895, but probably written during December $1894 .{ }^{4}$ Similarly, he also notes the controversies surrounding his essay 'De l'infériorité de la femme', which was published in the January 1895 issue of the symbolist journal La Revue Blanche, along with the newly written 'À la zoologie de la femme', as part of his contribution to the contemporary debate in France on woman's place in society, an intervention that brought Strindberg at least as much local notoriety as the recent production of Creditors by Lugné-Poë at the Théatre de l'EEuvre in June 1894. Furthermore, two references to the banquets which occupied a part of his time during this period, in the company of (variously) the publishers Albert Langen and Georges Charpentier, Lugné-Poë, and the poet and journalist Catulle Mendès, provoke the socially diffident writer to ponder 'what one should say' about the problems of prostitution and infidelity, and to recall, under his penname 'Columba', one of his adversaries, Henry Fouquier, 
who had rebutted Strindberg's views on women in an article in L'Echo de Paris (15 January 1895). His nom de plume qualified Fouquier for that most detested of Strindbergian categories, 'men who write under a woman's name' (män som skrifva i quinnans namn).

The most significant entries, however, are those which refer to the second of the five Inferno psychoses identified by Gunnar Brandell in Strindbergs infernokris. ${ }^{5}$ For it is here, in the events of December-January 1894-5, and in Strindberg's comments on them, that it is possible to discern certain underlying motifs that will reappear in the later autobiographical fictions from Inferno onwards. References to the 'Café Napolitain', where he was in the habit of taking his 'ear of Dionysus' (Dionysiusöra), or absinthe, between six and seven most evenings [X, 314; 2, 519] and to the cabaret at the 'Chat Noir', occasion the comment 'Néant'. From his correspondence with Frida, the role of the former and absinthe during this period of his life is apparent: 'An absinthe at the Café Napolitain sets everything in motion,' he told her in November 1894 [X, 300; 2, 517]. Meanwhile, both in its guise as Rudolphe Salis's well-known Montmartre cabaret where Strindberg once toyed with the idea of putting on a version of his fairy-tale play The Keys of Heaven (1892) rewritten according to fin-de-siecle dramatic principles and as the projected night club that he contemplated founding in Paris with Littmansson as a partner, the Chat Noir figured prominently in his mind at this time. 'Littmansson has been to see me and we have a plan to found a Chat Noir or a Procope Strindberg; I shall paint the walls and put on The Keys of Heaven as a shadow-play; my guitar will be there [and] Littmansson will direct the music according to the latest mode', he informed Frida, on 4 November 1894, before going on to admit that this would undoubtedly lead to 'chronic alcoholism and all the rest of it' [X, 296; 2, 516]. For in one of the preliminary structures that Strindberg was exploring as a possible template on which to organize his experience at this time, the 'Chat Noir' represented an alternative to the family he could no longer maintain either financially or in terms of his own psychological well-being. Anticipating the opposition between love and knowledge which underlies Inferno the cabaret was also the antithesis of Strindberg's other contemporary project, his desire to enter a monastery either of his own founding [X, 133-5; 2, 482-4] or an already established one such as the Trappist Notre-Dame d'Igny to which Huysmans retreated in 1891 or the Benedictine monastery at Maredsous where Strindberg would himself eventually stay briefly, in 1898. The words 'Klostret' (the monastery), 'La Trappe', and the life of an 'Erémite' (hermit) indicate the hold this scheme had on him at this time while in his correspondence he would frequently oscillate between the attractions of the cabaret or tavern, on the one hand, and his distaste for the degrading life of a bachelor on the town, on the other. 'The cabaret saves me from suicide' [X, 296; 2, 516], he told Frida in 
the same letter where he exclaimed in disgust, 'What a miserable existence! I detest mankind, but I can't stand being alone - hence: bad company, alcohol, late nights, Chat Noir, despair and all the rest of it' [X, 293; 2, 515]. But not until Inferno and To Damascus and the scenes in which he depicts his disturbed absinthe hour and the particles of soot that fall into his glass would he be able to place these conflicts in context, and create out of such apparent triviality the matter of his later art.

The same applies to the single comment 'Honour' (̈̈ran), which accompanies a reference to 'Père', or The Father, with which Lugné-Poë had followed up his recent production of Creditors at the Théâtre de l'CEuvre. (The Father opened on 13 December 1894.) The associations of honour in Strindberg's mind with pride, hubris and his choice of vocation, which again permeates the letters of this period, continues throughout the correspondence with Torsten Hedlund in 1896 and eventually finds its fully worked-out form in Inferno, To Damascus and Crimes and Crimes. The dramatist Maurice in the latter, for example, is exposed to the temptations of success and the nemesis divina that follows upon its appearance in the writer's life while the narrator of Inferno is confronted by the need to resolve the conflict between his vaunting desire for knowledge and power and the damage this inflicts on the life he might otherwise share with his wife and child.

But the climax of these notes, and what seems here to have been envisaged as the dramatic focus of any literary recuperation of his early Paris experience, is played down in his later writing. In these notes, however, a shaking hand produces

Hotellet. Den eviga elden. Vagname. Skakningen. Väck den [?]. Berättar Wedekind. Hamsun. Grétors besök. Det är visst julafton? Golfvet gungar; bordet skakar. Jag söker den fasta punkten! Hos andra! går ut.

[The hotel. The eternal fire. The waggons. Shaking. Wake it [?]. Tell Wedekind. Hamsun. Grétor's visit. It is surely Christmas Eve? The floor rocks; the table shakes. I am seeking the fixed point! With others! go out.]

In this instance, the straightforward list of names and subjects that characterizes the remainder of these notes is invigorated by the instantly dramatic present tense, as he recalls one of the most alarming of his many disturbing experiences during this period. A moment is relived intensely, namely the Christmas Eve that Strindberg spent in his lodgings at 14 rue de l'Abbé de l'Epée in 1894. Although he passes over these events in haste in Inferno, here they clearly stimulate ideas of 'Den eviga elden' (the eternal fire), and of a tottering world about to fall. For although he would subsequently toy with the idea that this attempt on his life was a surrogate for the suicide he had so often contemplated [X, 338], this note may be linked with a letter to Littmansson, written the 
day after the events mentioned here, in which Strindberg informs his friend that 'there was a devil here who wanted to murder me - so the innkeeper and I had to barricade the door when the murderer tried to force it' [X, 338]. And this assault was evidently associated in Strindberg's mind with Grétor and his circle, which included the emerging German dramatist, Frank Wedekind, and the Norwegian novelist, Knut Hamsun. ${ }^{6}$

Ever since Martin Lamm's early treatment of the status of these events in Strindberg's life, ${ }^{7}$ it has been customary to interpret this scene as just another unjustifiable outbreak of Strindberg's persecution mania. But since Sverker Hallén's ingenious close reading of the French text of the prose meditation 'In the Cemetery', in which he demonstrated how Strindberg had incorporated a passage into the original version of this essay published in Revue des Revues (15 July 1896), which reads on one level as an exercise in experimental symbolism based on free verbal association, and on another as a cipher of allusions intended for private consumption by Grétor and his circle, by whom Strindberg felt threatened, this is no longer possible. ${ }^{8}$ That there was substance in Strindberg's fears is now apparent. Whatever the precise nature of his insights into the underside of Grétor's activities as a trafficker in forged paintings or into the life (so finely dramatized by Wedekind some six years later in his play Der Marquis von Keith) that Grétor also forged for himself, Strindberg had reason to be alarmed at the power which Grétor might have over him from the time when he had stayed in Passy, in the house of Grétor's mistress, Rosa Pfaeffinger, and painted for him on commission. He thus sought to defend himself and in 'P-aris' he appears to have been considering relating what he knew quite openly. That he eventually settled for the allusive ingenuity of 'In the Cemetery' was probably more prudent, but in any event it is obvious that his relationship with Grétor and his contacts, although omitted from Inferno, played a role not greatly inferior to that of the Ferkel circle in stimulating his anxieties and shaping the course of his sometimes paranoid feelings during this period. If this is so then, for example, Strindberg's violent reaction to Knut Hamsun and the role which the latter played in collecting money among the Scandinavian community in Paris to alleviate Strindberg's destitution becomes more comprehensible, since Hamsun (as the note makes clear) was associated in Strindberg's mind with Grétor.

The question obviously arises why Strindberg never carried out this projected narrative. In part, as he wrote to Frida, it was because he had no one to write for, nobody who seemed willing to receive his more serious forms of expression: 'Write? But I have written so much. Paint, yet I have painted so much. The tavern [cabaret], Chat Noir, etc., clowning? No, I abhor the tavern, and yet am condemned to it!' [X, 298; 2, 516]. He was a writer without a public, a dramatist without a stage, the plays he had written before leaving Sweden 
in 1892 still unperformed there and the theatres of Paris now turning away from works by Scandinavian writers or contemplating a repertoire exclusively Ibsenite. And, as he asked Lugné-Poë, in December 1894: 'why must I [always] serve as Ibsen's gun-dog?' [X, 332; 2, 522].
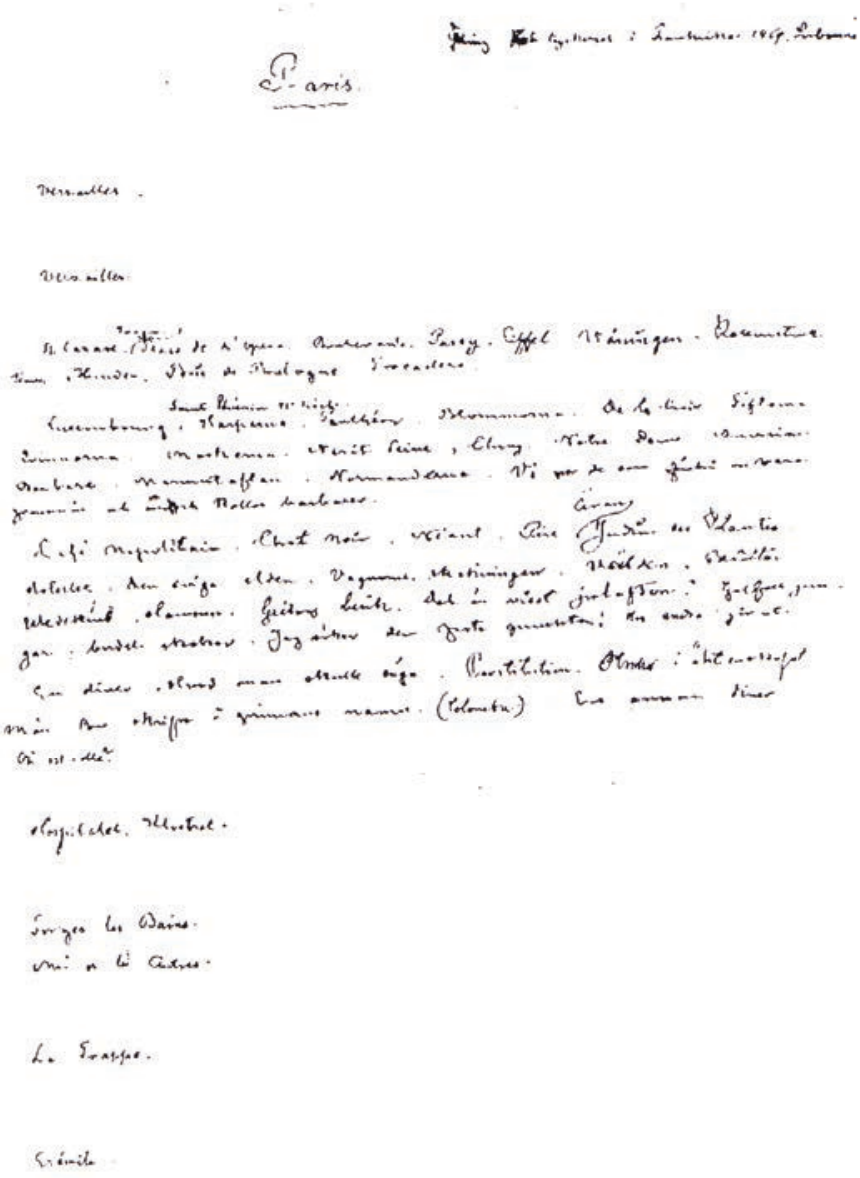

Reproduction of 'P-aris' [SgNM15 5,23] 
But the project was also no longer the type of literature he wished to write, at least in the straightforward transpository form of writing up his experience that these notes suggest. Since the furore created by his autobiographical fiction A Madman's Defence which had been published in France, pirated in Sweden and taken to court in Germany, he had been seeking an escape from the too naked exposure of naturalist writing $\grave{a}$ clef, that is, a prose narrative in which he transposed his shared experience directly into a literary narrative that appeared to countenance the reproduction of that experience with an immediacy rarely concealed behind only the most token camouflage. Hence 'I abandoned literature in order to escape being superficial' [XI, 138; 2, 547], he informed Torsten Hedlund, in March 1896, while in his reconstruction of this period in 1898, in The Cloister, his narrator recalls his writing 'the merciless portrayal of his first marriage' and recoils in the face of an occupation which lets the writer 'sit and fly [his] fellow human beings and then offer their skins for sale and expect them to buy them... To go about spying out people's secrets, to betray one's best friend's birthmark, use one's wife as a guinea pig, behave like a Croat, chop down, defile, burn and sell' [SV 50, 95]. He sought instead a manner of writing that was not so transparent and no longer 'superficial', where, in the terms he used of his paintings at this time, the esoteric meaning would supersede the exoteric $[\mathrm{X}, 178 ; 2,494]$. But this remained the achievement of later years. These notes suggest that 'P-aris' was all too obviously another series of episodes destined to be recaptured à clef. Before he could return to literature with an easy conscience he had first, as he writes here, to find 'den fasta punkten' outside himself, just as Axel Borg had remarked in By the Open Sea, Strindberg's novel from 1890: 'Give me a few more hypotheses, above all the fixed point outside myself, for I am quite adrift' [SV 31, 179]. Only when 'God, the fixed point outside us, by which alone we can accomplish anything' [XI, 284; 2, 585] was reestablished in his mind was Strindberg able to integrate the disparate parts of the Inferno experience in a formal narrative structure that would do them justice. 
Plots, Plays and Performance 



\section{Naturalism and the Plot in Creditors}

Although Strindberg used the Preface to Miss Julie to proclaim that the Naturalist had abandoned guilt along with God ('skulden har naturalisten utstrukit med Gud' [SV 27, 106]), all the major texts that he wrote in the wake of The Son of a Servant in 1886 present the problem of guilt, of a just apportioning of blame for the way in which the events of the plot have unfolded, as an insistent one. 'Vems är felet?', 'Vem bär skulden?', 'Vems är skulden till vad som skett?' ask the heroes and the heroine of The Father, A Madman's Defence and Miss Julie in turn: Whose fault is it? Who is to blame? Whose is the guilt for what has happened? And notwithstanding his attempt to approach and explain 'the harsh, cynical, heartless drama that life affords' [SV 27, 102] with a notional scientific objectivity, that is, to analyse human behaviour from the point of view of a vivisector for whom the stage has been transposed into an operating theatre for the dissection of human souls, at least one early reviewer, Edvard Brandes, perceived the way in which accounts are finally settled in Creditors (1888) as a serious lapse on Strindberg's part from the naturalist doctrine of the author's impassibilité. Moreover, Strindberg's pained response to Brandes' criticism of his putative protagonist, Gustaf, as a moralist and a preacher might well be interpreted as betraying his own unease over some of the contradictions in which his elaboration of the plot of Creditors in accordance with naturalist principles had embroiled him. ${ }^{1}$

The context of his predicament is, of course, the evident loss during the nineteenth century of what Peter Brooks has called the 'sacred masterplot that organizes and explains the world', and hence the proliferation in history, mythology, anthropology and evolutionary biology (to mention only a few of the possibilities that Strindberg himself explored) of other scenarios wherein 'the plotting of the individual or social or institutional life story takes on new urgency.' ${ }^{2}$ This was ostensibly the position from which Strindberg felt compelled to write the natural history of his own life in The Son of a Servant, the one narrative which, or so he maintained in the fictitious interview that he wrote for his autobiographical fiction in lieu of a preface, was the privileged, indeed the sole story that the naturalist writer was in a position to tell with authenticity and authority [SV 20,373]. Nevertheless, when he returned to 
depicting the destinies of fictional characters in the late 1880s, he was still confronted by the exigencies of translating the plot laid down for individuals by their heredity, environment and the historical moment of their lives into effective theatre even though this plot, as his investigation of his own life had importantly demonstrated, was at once too vast and multiple in its combination of personal minutiae and immemorial interlocking causation ever to admit a clear, univocal interpretation or representation. 'The stone is set in motion,' as Adolf observes, in Creditors, 'but it wasn't the last drop of water which started it off, nor the first one - it was all of them together' [SV 27, 228]. Thus he goes on to conclude, using both the textual and the mathematical patterns of imagery which pervade this play, that one can neither 'translate a varied life into a single figure' (ett ensiffrigt tal [SV 27, 249]) nor make it all add up neatly since, quite simply, when one analyses the data of individual experience, 'it doesn't add up to a round sum' [SV 27, 250].

This is hardly surprising. At the time Strindberg was experimenting with a world view in which man was regarded as continuous with nature and conceivably subject to impersonal laws. Moreover, as Miss Julie remarks, in a last attempt to find the key to what has taken place during her last Midsummer night, as a consequence of the multiple motives enumerated by Strindberg in the Preface to the play [SV 27, 103]:

Who is to blame for all this? My father, my mother, myself? But I have no self of my own. I haven't a thought I didn't get from my father, not an emotion I didn't get from my mother, and this last idea - that everyone's equal - I got that from him, my fiancé. [SV 27, 187]

In Strindberg's naturalistic plays, man's determinations now emerge as not wholly his own, although s/he reaches them, and what the individual does seems to be at once himself, and therefore his responsibility, and yet, at some very real but submerged level, not himself. Determined yet strangely free and responsible before the 'mångfald av motiv' (multiplicity of motives [SV 27, 104]), the individual dwells in the accident of his character forever.

Moreover, while he sometimes professed a modish indifference to the implications of the naturalist world view ('after all the downfall of one family is only another's good fortune, it takes its place, and this alternation of rising and falling is one of life's greatest pleasures' [SV 27, 102]), Strindberg was nevertheless evidently disturbed by the apparent absence of any trace of moral order if, as he explained in The Son of a Servant, 'one doesn't choose one's urges' [drifter, SV 21, 16], and one's 'path was inevitably determined by heredity, temperament, and place in society' [SV 21, 147]. Indeed, in the most extreme formulations of his naturalist period, when he sought to dissolve the notion of a fixed, substantial selfhood which acts with conscious purpose and intent, 
Strindberg had placed in doubt the very notion of a plotted life. Like his near contemporary, John Ruskin, who referred to man as '[this] drift of human dust, and current of interchanging particles. ${ }^{3}$ Strindberg, in the Preface to Miss Julie, depicted the individual as a 'split and vacillating' patchwork made up of 'various stages of culture, past and present, scraps from books and newspapers, bits and pieces of different people, [and] shreds from fine clothes that have become rags' [SV 27, 105], and portrays such a figure in the heroine of the accompanying play, where Julie describes 'life and people [as] a scum which drifts, drifts on across the water, until it sinks' [SV 27, 135].

Certainly, there would seem to be no place in the form of drama envisaged in the preface to Miss Julie, where nature holds no clues nor answers to human moral dilemmas, for a plot that incorporates any conventional patterns of crime and punishment, or suffering and justice. Nor, indeed, does it seem possible in closing the plot to fall back on any of what Joseph Conrad (in 1905) wryly termed 'the usual methods of solution by rewards and punishment, by crowned love, by fortune, by a broken leg or sudden death'. ${ }^{4}$ And yet, of course, this is precisely what Miss Julie and - more elegantly - Creditors appears to do. With something of the formal precision of French classical tragedy, and progressing in three continuous scenes by means of a neat and almost stylized exchange of conversational partners that permits each side of a more or less conventional dramatic triangle to be illuminated in turn (the play might thus be appropriately located somewhere between Racine's Andromache and Beckett's Play), the action of Creditors embodies the working out of the equation contained in the initial situation in such a way that when it ends, the 'wronged' husband, Gustaf, has settled his account with his former wife, Tekla, and the man for whom she left him, Adolf, and can thus depart, his debt collected with the same punctiliousness as he pays the hotel bill for which he now rings.

Notwithstanding the self-consciously ironic tone of the play, which suggests that any attempt of the kind which Tekla (like Edvard Brandes) makes near the close to translate its network of financial imagery to do with debit and credit back into outmoded concepts of guilt and punishment is a regression in search of the false consolation conferred by fictional meaning, this formal as well as thematic consonance is achieved because the semantics of payment and debt and those of guilt are the same in Swedish as they are in several other European languages. The dual sense of 'skuld' as both 'guilt' and 'debt' allows Strindberg to establish and exploit a link between morality and economy, or price and retaliation, as essential features of what (in the novel Gothic Rooms of 1904) he will later define as 'this confused account of out and in, debit and credit, which is called life' [SS 40, 78]. Moreover, the frequent play upon popular expressions to do with the settling of accounts, paying off old scores, and balancing accounts throughout the text of Creditors enables him to summon 
up (notably in Gustaf's eloquent evocation of the Fall of Man in relation to Tekla's original adultery with Adolf) the deeply engraved trace of an ancient masterplot which, though redundant in terms of the vivisector's apprehension of the world, retains a capacity to animate and organize the text.

What one has here is, firstly, the adroit exploitation of those ghostly residues in language which linger on to provide the seemingly necessary armature of intelligibility in the text, rather like those spectres which Mrs Alving had shared with her audience a few years previously, in Ibsen's Ghosts. There is also the intimate psychological level where this dramatic triangle summons up, whether consciously or not, aspects of what in an unpublished note among his surviving papers Strindberg once referred to as the 'Affaire W-l' (SgNM 9:3, 21), that personal 'corpse in the cargo' [SV 27, 208] which recalls his relationship with Siri von Essen and her first husband, Car! Gustaf Wrangel, and which so often imprinted itself on the features even of his most evidently fictional texts, as here in Gustaf's name or the otherwise superfluous inclusion in the play of a child which was put away and died, on the grounds that it had begun to resemble Tekla's first husband, much like the one which Siri bore Strindberg less than a month after their marriage [SV 27, 208]. Similarly, the whole network of associations provoked by the vain attempt of Tekla and Adolf 'to play at brother and sister' [SV 27, 212] in the face of Gustaf's omniscient assumption of the patriarchal scriptor's role as the first corner, who fills Tekla's emptiness, or vacuity (tomrum), and inscribes his primary text upon her 'slate' [griffeltavla, SV 27, 261], ${ }^{6}$ evokes the imagery and circumlocutions of the correspondence with which Siri von Essen and Strindberg first seduced each other, and which Strindberg subsequently wished to see published as the epistolary novel He and She, as well as his first detailed treatment of the Woman Question in the play Sir Bengt's Wife (1882), which was also conceived as a vehicle to further Siri's theatrical career. And as in Miss Julie, where the coupling of Jean and Julie takes place in the shadow of the patriarchal Count, her father, the triangular relationship of Gustaf, Tekla and Adolf tellingly evokes the primal scene of Eden.

Ultimately, however, the power at large in Creditors to punish transgression comes from a preparedness the author shares with at least one of his characters to feel a guilt that has been internalized, irrespective of any of the arguments deployed to dismiss it in the course of the play. It erupts from within and, as Strindberg's later career amply demonstrates, it will brook no repression. Thus, in relation to Adolf and his former wife, Gustaf is also a kind of ghost, an embodiment of the past, and in her final speech Tekla acknowledges the fatal consequences of his return to haunt her, collect his dues and complete a plot in which his creator is also implicated: 'He who sees his own ghost [fylgia] dies' [SV 27, 272]. 
But more immediately crucial for the way in which the play is plotted than either of these aspects is the fact that behind the thematic relevance of the many allusions to finance and book-keeping, and hence to the ideas of order, morality and justice which they inescapably promote, there lies a complementary concern for aesthetic harmony, consonance, and poetic justice. For although the play may predicate a world without transcendence and hence one which lacks a guiding moral law, it requires its own internal coherence if it is to be dramatically effective. Even if life is identified as the formless 'scum' (sörja) of Miss Julie [SV 27, 135], an arbitrary concatenation of events devoid of any trace of those principles which might conceivably establish an order in human behaviour that works towards some comprehensible and just end, the naturalist writer is nevertheless compelled to embody the sense of such a world in a work that has artistic form, to have, if not a carefully fashioned beginning, middle and end, then at least an effective dénouement for that single scene ('la noix', the nut, as he called it in a letter of 29 November 1888 to Georg Brandes [VII, 184; 1, 291] $]^{7}$ which Strindberg currently believed was the substance of every worthwhile play. And hence, when Tekla finally raises the question of blame or guilt in human action in order perhaps partly to exonerate herself from any responsibility for the plot in which she is now caught up ('Christians say that it is Providence which governs our actions, others call it fate, aren't we innocent?' [SV 27, 269]), Gustaf's response, in the awkwardness of its attempt to reconcile the contradictions in which he, too, is trapped, might conceivably be seen as an expression of the dilemma of the naturalist writer, compelled to give form to human action and yet lacking the moral framework that would authorize the order which comes into existence along with the formal logic of the text: 'Up to a point, yes. But there's always a margin where guilt creeps in; and sooner or later our creditors present themselves! Innocent, but responsible! Innocent before Him, who no longer exists; responsible to oneself and one's fellow men' [SV 27, 269-70].

As the play proceeds, Gustaf also takes on an authorial role, not merely because, like Strindberg, he is determined to impose his text upon those around him and allot them parts in the drama of his life (in Strindberg's case this was then a matter of the role his wife should play both in and outside the theatre), but also because - as Edvard Brandes noticed - he seems to become the spokesman of the plot, almost the intrigue maker himself indeed, someone who stages his scene with Tekla in order to capture the attention of Adolf in the adjacent room before an audience that is as hypnotized by the events on stage as Adolf is, an audience, moreover, that is also, because of its voyeuristic role, made up of Gustaf's confederates.

What is more, Tekla also senses this. At one point she accuses Gustaf of creeping in with 'a vile plan to destroy my happiness' [SV 27, 266], something 
that he rather disingenuously denies. He did not plot what is taking place; things merely turned out as circumstances and the situation ordained. Having spotted Tekla on the steamer, he felt drawn to look in on her. Then 'your lamb [i.e. Adolf] threw himself straight into the arms of the wolf [SV 27, 266] and provoked him by recalling the book in which - like Strindberg in A Madman's Defence - she had given a public account of her first marriage, and branded him an idiot. Even so, when she returned, Gustaf claims not to have been following a preordained script: 'I didn't really know what I was going to say. Like a chess player, I had a number of possible plans, but which one I used depended on the moves you made. One thing led to another, chance played a part, and so I had you ditched' [i sumpen, SV 27, 267].

But once scripted chance can appear more theatrical or melodramatic than other aspects of the plot, as when, in Creditors, two female figures suddenly appear at the verandah door, apparently on cue, to catch Tekla in the embrace of Gustaf's compromising arms. The ultimate authority resides now not with the action but the author, who has written the event into his text: Gustaf is only his interpreter. Lacking a preordained script, it is the playwright who now selects events and dispenses justice. As his friend Birger Mörner once recalled Strindberg observing: 'Writing plays is nevertheless the most interesting of all. It means sitting like a little god and probing people's hearts and reins... judging them... punishing, acquitting or rewarding. ${ }^{8}$

On the one hand, therefore, the coherence and order which the play assumes as a work of art appears to readmit such order into the world it depicts: lives assume the contour of a plot, individuals gain destinies they may not themselves perceive, but which the audience is invited to unravel, and the actions of the characters produce not a random sequence of events but an interpreted series that concludes with a settling of accounts, a dramatic resolution which seemingly leaves no end untied. On the other hand, rather than being a regression to the artificial play-making of the pièce bien faite, as has sometimes been suggested, the degree of formal organization in Creditors already anticipates the patterning of Strindberg's post-Inferno drama, the repetitions and echoes of The Dance of Death, Crimes and Crimes, and To Damascus. In the series of dialogues between the different partners here, there is an element of play, and the three consecutive scenes amount to a kind of game like musical chairs, which affords both formal pleasure and a sense of life as theatre - as becomes apparent when Gustaf stage manages Adolf: 'I'll take up my post in there and watch while you play your scene in here. And when the performance is over, we'll change parts' [SV 27, 227]. Indeed, given the relatively small role played by the environment in fostering these characters' lives, it is the form rather than the set which creates the boundaries within which they are confined. And while the metatheatrical standpoint of A Dream Play is not 
yet explicit, there is in Strindberg's Naturalism, and particularly in its sense of character emplotted in action, an indication of the way in which people assume and exchange roles in the interplay of life which generally distinguishes it from Ibsen's dramas of contemporary life. In Strindberg, as Creditors goes some way to demonstrate, life is always theatre - and theatre, life. 



\section{Prisoners at Play: Form and Meaning in The Dance of Death and Beckett's Endgame}

In his finely-argued analysis of the opening pages of part one of Strindberg's The Dance of Death, Egil Törnqvist remarks in passing upon a particularly 'Beckettian segment' of dialogue between the Captain, Edgar, and his wife, Alice. ${ }^{1}$ To read, or better, witness Endgame and The Dance of Death in close proximity yields, however, more than one such passage, and it requires only a little ingenuity to come upon several noteworthy similarities between these two plays both as regards the situations they depict and their language, structure, dramatic method, and underlying themes, that are remarkable enough in themselves to compel the attention of the spectator or reader.

Although these similarities are not on their own account the main subject of this discussion, it is nevertheless useful to provide a basis for an examination of the relationship between theatrical naturalism and absurdist modernism by establishing a number of the most striking of them at the outset. Both plays, for example, commence with tired invitations to play from characters who are confined together with a companion in situations in which time passes only very slowly, and where one of the figures is soon identified as living in the shadow of a death which may at last set his reluctant companion free. 'Won't you play something for me?, Edgar asks [SV 44, 13], to end the silence which succeeds the raising of the curtain upon The Dance of Death, while some three pages later, after several conversational gambits have been tried and found wanting, Alice breaks another long pause by asking the Captain, 'Do you want to play cards?', to which he responds, with little enthusiasm, 'Why not?' [SV 44, 18]. Meanwhile the even older and more weary protagonists of Endgame begin by commenting tonelessly on the current state of play ('Finished, it's finished, nearly finished, it must be nearly finished,' [p. 12]) and then, in Hamm's first words, by informing the audience that it is now 'Me - (he yawns) - to play' [p. 12]. ${ }^{2}$

Immediately afterwards, in The Dance of Death as in Endgame, this opening theme moves rapidly from whatever occasions its dramatic presence in the text (in Edgar's case the piano at which Alice might have eased the atmosphere) to a 
second order meaning of metaphor and suggestion. Behind the surface realism of Edgar's request lie associations with his wife's past as an actress whose career has been cut short by marriage, and to the role-playing in which they both now indulge, while in Beckett's characteristically self-conscious script, Hamm's opening statement is followed by a succession of remarks which, from his early assurance that 'We're getting on' [p. 15] and Nell's query, 'Why this farce, day after day?' [p. 18], to Clov's claim that 'Things are livening up' before an audience he has magnified into 'a multitude... in transports... of joy' [p. 25] and then to the many later allusions to the characters' theatrical predicament ('I'm warming up for my soliloquy' [p. 49], 'Not an underplot I trust' [p. 49], 'This is what we call making an exit' [p. 51]) all monitor the progress of the play and comment upon its own career as a theatrical text. Indeed, Endgame is overtly metatheatrical and engaged, as Ross Chambers observes, in the familiar modern pursuit of providing 'a kind of image of itself, commenting on itself as a play and thus commenting on life itself as theatre. ${ }^{3}$

But Strindberg's apparently naturalistic drama also displays, if only briefly, the acute self-consciousness about its own artistic nature which is normally associated with modernist texts. Just as The Ghost Sonata directs an audience towards its affinity with the fairy tale as a possible means for recuperating what is obviously an innovatory work, ${ }^{4}$ so The Dance of Death likewise defines the terms with which it should be apprehended. These assign it neither to tragedy nor comedy but to the then proliferating genre of grotesque tragi-comedy to which Endgame, with its knowing recognition that 'Nothing is funnier than unhappiness... it's the most comical thing in the world' [p. 20], also belongs. As Kurt remarks, of Edgar, 'He'd be comic if he weren't tragic' [SV 44, 81], and both in his early observations on the need for mirth to alleviate the boredom of living [SV 44,28] and in his concluding speculations on the way in which 'When it's a farce it [life] can be most painful, when it's serious it can be quite peaceful and pleasant' [SV 44, 135], Edgar manifests a contemporary response to experience and the way in which it contravenes traditional artistic categories.

It is, however, primarily the way in which both plays combine surface detail and dialogue with the underlying structure and setting which at first compels comparison and yet eventually permits certain important distinctions to be made. It is, for example, tempting to see The Dance of Death as structurally a prefiguration of the many closed circles of Beckettian drama like the da capo reprise of Play, Krapp's spooling tape, or Godot's affinity with the round song that Vladimir sings at the start of Act Two, in all of which, as Clov remarks, time appears continuously 'the same as usual' [p. 13], and where 'The end is in the beginning and yet you go on' [p. 44]. Moreover, given the way Strindberg's play ends as it began with Edgar alone once more with Alice, in an echo of the opening image, it might even seem apposite to regard the 
Captain's final words, 'Well. Let's go on' [SV 44, 135], as an uncanny preview of Estragon's famous admonition at the close of Waiting for Godot, 'Let's go. (They do not move.).'

This was in fact the effect achieved by Max Reinhardt's famous 1912 production of The Dance of Death at the Deutsches Theater, which opened and closed with Alice and Edgar sitting far apart from each other, motionless and in silence, staring out into nothingness with their backs toward the audience, in a set which accentuated the impression of an earthly hell where people torment each other by extending the stage in a half circle out into the orchestra, so reinforcing the effect of Strindberg's stipulated grey stone circular fortress tower and suggesting the total confinement of the actors within an unbroken circle, in what again evokes the claustrophobic stage image of Endgame. ${ }^{6}$ And while it is certainly true that Reinhardt's mise-en-scène overlooked the fact that in Strindberg's stage directions, the final tableau is actually broken by the Captain who rises to his feet in order to reinforce the urgency of a curtain line which carries the burden of the important inner change he has undergone in the course of the play (he is no longer tired and bored nor fingering a spent cigar, as in the opening tableau, either), it nevertheless conveyed superbly the implication of Strindberg's pithy reformulation of Kierkegaard's notion of repetition, 'Everything comes full circle' [Allt går igen, SV 44, 69], which he had adopted not only as an important element in his later view of life, but also as a principle of dramatic construction. This was notably so in the first part of To Damascus, whose form, according to Strindberg,

symbolizes 'The Repetition' that Kierkegaard speaks of: the action unrolls forward to the Asylum; there it kicks against the pricks and rebounds back through the pilgrimage, the relearning, the eating of one's words, until it begins again at the same point as the action stops, and where it began. [XII, 279; 2, 624]

But the same basic structure is also applied to Crimes and Crimes, in which the settings in the first part are again recapitulated in the second, and to The Dance of Death, which plunges downward into the demonic savagery of Act Two, Scene One, before returning to the relative tranquility of the final scene in which Edgar and Alice, having come to understand that they 'have apparently been condemned to torment each other' [SV 44, 132], prepare (like Beckett's characters) for the liberation death brings, for the moment when, like Clov, they 'will open the door of the cell and go' [p. 51].

Similarly, in their tendency either to return the speakers to silence or to their starting point, the shorter units of stichomythic dialogue into which the text is often divided already foreshadow the highly formal, patterned exchanges of Beckett's couples in both Waiting for Godot and Endgame. And of course the 
Beckettian tone and feel of the text on which Törnqvist remarks (what Beckett, in relation to his own play, has called, 'the power of the text to claw'), 7 is largely fostered by the way in which each speaker has his or her 'repertoire' of stories, memories, or melodies that the other knows by heart, and which are hence incapable of dispelling the fatigue or boredom either of the player or the listener. Each gives the other their habitual cue: 'Just now, when you made the same old reply, "In this house, anyway", I should have replied with my old "it's not just my house"' [SV 44, 30-1], Edgar points out, in recognition of a departure from the familiar script, just as, in the French edition of Endgame, Hamm responds to Clov's 'A quoi est-ce que je sers?' by observing 'A me donner la réplique, ${ }^{8}$ an exchange which emerges as 'What is there to keep me here? / The dialogue' in the English version [p. 39]. Visually confined within the circular fortress or their bare interior, both sets of characters go the rounds of their relationship with well-worn conversational gambits and rapidly exhausted verbal counters in an attempt at securing a temporary advantage over the partner, or opponent, with whom they form, in Mrs Rooney's colourful expression in All that Fall, 'The perfect pair. Like Dante's damned, with their faces arsy-versy', ${ }^{9}$ two creatures who are, as Alice explains, when Kurt wonders why she and Edgar have not parted, 'welded together and can't break free. Once we lived apart - in the same house - for five years. Now only death can part us; we know that, and so we wait for him as our deliverer' [SV 44, 52]. 'All life long the same questions, the same answers,' Clov remarks [p. 13], of this ritual performance of word and gesture, in which dramatic event has virtually given way to the immobility of a situation, 'the end of the day like any other day' [p. 17] where 'we say the same thing every day' [SV 44, 30].

Frequently these gambits end in stalemate as, typically, in the opening segment of The Dance of Death:

CAPTAIN: Won't you play something for me?

ALICE (indifferent, but not crossly): What shall I play?

CAPTAIN: What you like.

ALICE: You don't like my repertoire.

CAPTAIN: Nor you mine. [SV 44, 13)

or from Endgame:

HAMM: Why do you stay with me?

CLOV: Why do you keep me?

HAMM: There's no one else.

CLOV: There's nowhere else.

But occasionally, by the adroit application of the mainly linguistic codes of the game ('Since that's the way we're playing it,' Hamm concludes, 'let's play it 
that way' [p. 52]), one or other player sometimes gains a temporary advantage. For example:

CLOV: Do you believe in the life to come?

HAMM: Mine was always that. (Exit Clov.) Got him that time. [p. 35]

or:

ALICE: I can hear the Alcazar waltz, the melody. Yes, it's some time since I danced a waltz...

CAPTAIN: Could you still manage it?

ALICE: Still?

CAPTAIN: We-ell? You're done with dancing, aren't you, like me?

ALICE: But I'm ten years younger than you.

CAPTAIN: Then we're the same age, for the lady is always ten years younger. [SV 44, 23-4]

Here, the mortal struggle between husband and wife is carried out in language, and points are scored by turning one's opponent's words back upon the speaker, as they often are in Endgame. But behind the thrust and parry of the dialogue in The Dance of Death there is a world of conventional referential meaning which supplies the combatants with ammunition and the social rules of the game ('the lady is always ten years younger'), whereas in Endgame the rules are produced by the power of the text itself to evoke its own world of meaning: 'It'd need to rain', Hamm says; 'It won't rain', Clov replies [p. 13]: move and countermove. As Anthony Easthope observes:

the verbal surface of the play is pervaded by a deliberate artifice, which never allows an audience to forget they are watching a game played according to certain rules.... And a principal effect of the drama derives from the deft manner in which a consciously sustained surface, itself a meaningless exercise in various techniques, is held in tension with the expressive significance of what is suggested beneath it. ${ }^{10}$

It is, however, a surface which the spectator is able to engage with precisely because it seems to adhere to the conventions governing conversation and stage dialogue established in such texts as The Dance of Death.

For however various the underlying motivation behind what the characters say in The Dance of Death, its language assumes the possibility of at least a partial explanation of the action in terms of character and situation, both of which are rooted in what is recognizably the theatrical reproduction of 'everyday' life. Though immensely complex and engaged in uncovering the landscape of another truly infernal domain behind the familiar features of a late-nineteenthcentury household as pointedly as Endgame is with its references to 'the other 
hell' beyond this one [p. 23], Strindberg's text is governed by conventions that are largely realist. What we witness is an action performed by characters who think, behave, and respond to each other in the manner and according to the motivations of people in the world outside the theatre. For the most part, therefore, the codes by which an audience interprets what it sees are taken from its experience and expectations of life, and what it understands to be the appropriate (or merely the dominant) mode of displaying this life on stage. To take one recondite but precise example. When the Captain toys with the notion of 'a broiled mackerel with a slice of lemon and a glass of white burgundy' [SV $44,14-15]$ and asks his wife if it is not the time of year when mackerel are to be caught, the reference to mackerel is sufficient to correct the common assumption that The Dance of Death is set in the Stockholm archipelago which Strindberg knew and loved, and where several other major works (The People of Hemsö, By the Open Sea and parts of A Dream Play) are sited. Mackerel are not fished in the Baltic but on the Swedish West coast, which is thus the correct location for the play. ${ }^{11}$

In Endgame, on the other hand, few such conclusions can be drawn. The text is self-referential, and where it invites, or at least permits, speculation on a meaning or an association which is offered by the page or audible in the theatre, it rarely - if ever -confirms any meaning the reader or spectator may extrapolate, and even then not in terms of a realistic psychological motivation or plot expectation, or as an immediate reflection of the world to which he or she will return at the end of the play, but only as one among many possible meanings implicit in the organization of the text. As Beckett wrote, in a letter to AIan Schneider, 'If people want to have headaches among the overtones, let them. ${ }^{12}$ There is no precise indication of where, or even when, the play is set, and any specific reference like Nagg's allusion to 'the road to Sedan' [p. 19] refers to a past about which it is impossible to be precise. The interpreter is abandoned to a set of associations which cannot be confirmed, but which, in keeping with the catastrophe that brought these characters to their present state, may well evoke memories of 1870 or 1914-18. For whereas in The Dance of Death the focus is first and foremost upon the achieved illusion of characters animated by life, in Endgame the life portrayed is in the words. It is the language to which the characters have been committed that is active and which propagates not only the drift towards meaning which is what those who are forced to use it [p. 32] fear and seek to prevent ('We're not beginning to... to... mean something?', Hamm asks in alarm [p. 27]) but life itself, as on the occasion of the misplaced vowel to which Clov is led by his concern to exterminate the flea:

HAMM: Did you get him?

CLOV: Looks like it... Unless he's laying doggo.

HAMM: Laying! Lying you mean. Unless he’s lying doggo. 
CLOV: Ah? One says lying? One doesn't say laying?

HAMM: Use your head, can't you. If he was laying we'd be bitched. [p. 27]

But notwithstanding this distinction regarding the role played by language in these two plays, The Dance of Death and Endgame nevertheless derive their dramatic effectiveness from similar strategies and to surprisingly similar ends. If the surface text of The Dance of Death appears to reproduce the seemingly random flow of speech in the conflicts of people living together in the social world, according to the notion of dramatic dialogue that Strindberg had developed in the Preface to Miss Julie, where he envisaged stage conversation that 'wanders, providing itself in the opening scenes with material that is then taken up, worked over, repeated, expanded and added to, like the theme in a musical composition' [SV 27, 109], its deep structure already evokes in its subtle choreography of sound and silence, and light and darkness, another dimension. This is not a throwback to the bitter naturalistic universe of The Father and Creditors, ${ }^{13}$ but, like so many of Strindberg's other works from the period following his intellectual and emotional crisis in the mid-1890s, a pre-echo of the purgatorial worlds of Play or How It Is as much as of the marital hell of Who's Afraid of Virginia Woolf. There is in fact a noteworthy consonance between the world of The Dance of Death and Beckett's post mortem landscapes of tormentors and tormented, of figures imprisoned in cycles of sin, guilt and purgation where the real crime (as Strindberg was also inclined to believe) is what Beckett calls 'the original and eternal sin... the sin of having been born.' ${ }^{14}$ All their characters, authorial surrogates, and writers or story-tellers have, of course, committed this crime, and both Strindberg and Beckett compose works in which they or their characters evolve eschatologies of guilt and expiation in order to endow their lives with meaning, to explain the otherwise incomprehensible suffering of their being, or (as one of the voices in That Time puts it) simply 'to keep the void from pouring in on top of you. ${ }^{\prime 15}$ Hence the recurring uncertainty in both writers as to the true nature (infernal or purgatorial) of this world, and the notion that our existence here is a consequence of crimes committed in a previous existence, as Strindberg first conjectures in his autobiographical fiction, The Son of a Servant. Or as Clov phrases it: 'you must learn to suffer better than that if you want them to weary of punishing you - one day' [p. 51]. ${ }^{16}$

This infernal context, which becomes more specific in the course of The Dance of Death, as the seemingly casual early metaphorical references to the hellish life which the inhabitants of the island named 'Little Hell' [SV 44, 109] are leading gain substance in their gradual realization that 'this must be everlasting hell' [de eviga kvalen, SV 44, 134] and must be viewed as such, ${ }^{17}$ is reinforced by the setting. In both plays this offers the spectator a complex visual metaphor of the situation each drama is exploring. Although specific 
details may remain elusive (do the two small windows high up in the wall resemble eyes, and is it therefore the inside of a skull, an echoing chamber of the mind or 'large hollow sphere, hermetically closed to the universe without', such as Murphy conceived in Beckett's early novel, ${ }^{18}$ which is represented on stage?), Endgame is, like many other absurdist works, readily perceived as a concrete stage image, the projection on stage of a powerful inner landscape. But The Dance of Death, no less than the more obviously experimental The Ghost Sonata, which Beckett saw several times in Roger Blin's production at the Gaité-Montparnasse before writing Endgame, ${ }^{19}$ already seeks to express the atmosphere of the inner conflicts by which the characters are possessed through the physical features of the setting, rather than via the immediate naturalist determinism of the environment on character.

In this respect the circular granite island fortress is only nominally a straightforward realistic location. Whereas in his naturalistic dramas Strindberg had often been content with the trappings of a relatively poor theatre (Creditors, he told a publisher with well-placed enthusiasm, would require only 'three characters, a table and two chairs, and no sunrise' [VII, 105; $1,281])$, the unusually careful and specific stage directions for The Dance of Death conjure up an image that is essentially the crux of the situation depicted in the play. The curtain rises upon the red light of the setting sun glinting on the sabre of the sentry on watch outside the window. That he is there to guard those within as much as to protect them from a threat from without is a possibility which Edgar's reference to 'Baron Bluebeard with the maiden in his tower. And outside the sentry marches up and down with his sabre drawn, to guard the fair virgin' [SV 44,59] later confirms. It is an evening in autumn ('Outside and in,' as the Captain lugubriously remarks [SV 44, 14]), and the surrounding sea is calm and still, although the gun batteries pointing out across it invite the supposition that they may be defending those within from a hostile force without. Taken together what is being evoked in a multiplicity of ways is the fact of ageing, or extinguished vitality, and the imminent threat of death, not least in the appearance of the ailing Captain, who at the outset offers an image of impotent manhood. He has laid aside his parade uniform and is now dressed in a worn, undress uniform and fingering a burnt-out cigar, all libidinal passion seemingly spent. Situated on the margin between land and sea, or life and death, the tower is thus a precarious last post where the Captain is poised for departure on that final journey which Strindberg often portrayed in terms of a sea voyage. In The Ghost Sonata, The Pelican and the late dramatic fragment Toten-Insel (1907), for example, one or more of the principal characters embarks from life to death by way of water on a voyage that Strindberg represents both in personal terms, as an escape by steamer from the contamination of earthly life in the corrupting city to the islands of 
the Stockholm archipelago, and through the traditional image of the deceased being ferried to rest in Arnold Böcklin's celebrated painting of 'The Isle of the Dead', which provided, in reproduction, part of the decor of the Intimate Theatre where these plays were first performed.

Again, a comparison with Endgame, in which Hamm and Clov wait for the moments 'to mount up to a life' [p. 45], confined in a room where they watch their 'light dying' [p. 17], inevitably suggests itself, and indeed the life lived in the two beleaguered interiors offers similar accounts of reduced circumstances, in which the Burgundy, the food, and the servants in The Dance of Death, disappear like the pap, bicycles, pain-killers and biscuits in Endgame. It is likewise a world where sight is fading [SV 44, 16] and people have forgotten how to count [SV 44, 20], a world, in short, that is approaching extinction, the void which Edgar identifies as ending everything early on in the play [SV 44, 15] resembling the 'corpsed' [p. 25] universe of Endgame. Nevertheless, it is a world where, like several of Beckett's characters, including Winnie in Happy Days, he continues to recall moments of fleeting pleasure ('but we had our fun now and then' [SV 44, 15]) and days of earlier happiness: 'Those were our happiest days, in spite of everything' [SV 44, 23].

These or other likenesses between The Dance of Death and Endgame have obviously not entirely escaped earlier commentators. It is often pointed out how many absurdist plays also depict a situation in which man is imprisoned in a friendless universe where he is spiritually and physically isolated, bored, and yet unable to communicate with the companions to whom he is hellishly bound in an ambivalent love-hate relationship. ${ }^{20}$ In Strindberg's Impact on France, for example, Anthony Swerling sees Endgame as one in a group of plays (the others are Sartre's Huis clos, Ionesco's Les Chaises and Vauthier's Capitaine Bada) which form what he calls

a cycle of sequestration characterized by the confrontation and collision of the couple, by loneliness and monotony, exhaustion alternating with passion, mental cruelty and incompatibility, the framework of which can be traced back to the tightly-chambered crepuscular anguish of Edgar and Alice. ${ }^{21}$

Moreover, with his customary hyper-sensitivity to a possible echo of a Strindberg text in any modern French drama, Swerling goes on to presume and catalogue a series of additional points of contact between the two texts which suggest that Beckett, like every other dramatist writing in French between 1920 and 1960 , must have spent years in the close textual study of Strindberg.

The essential point of any convergence between the two texts lies, however, not in the opportunity to claim, as Swerling does, an influence where there is only meaningless coincidence ${ }^{22}$ but for what it may reveal of one of the major 
developments which drama undergoes between the late nineteenth century and the present. Or to put it more exactly, the process whereby Naturalism, as the last movement in drama to accord unequivocal status to plot, language and character (and even then, as the Preface to Miss Julie reveals, to dissolve the last of these into an unstable, discontinuous mosaic wherein character is the product of impersonal forces and the discourses which flow through it), gives way to a modernist theatre of stage image and theatrical metaphor. What is at issue here is that inward turn common to a large part of modern drama, in which a loss of confidence in spoken language and the move towards reviving concrete theatrically-specific modes of expression take place at the same time as the portrayal of external social reality is supplanted by the projection onto the stage of inner states of being. It is where a drama based on traditional notions of plot and character is superseded by a thematically organized theatre of situation, in which the discursive narrative element has been largely replaced by a static theatre of images, of scenic metaphors which appeal to the subconscious rather than to the conscious mind. In short, that crisis wherein drama, or at least the post-Renaissance notion of drama as the direct and objective presentation in dialogue of events unfolding in a recognizable world at the moment of performance, is placed in doubt (and indeed, there is barely an account of Beckett's theatre, particularly of the later works, which does not allude to the ways in which it questions the very possibility of drama).

For unlike the novel, which readily accommodates the late-nineteenthcentury turn towards inwardness, where intensity of suffering substitutes for action and man's isolation from his fellows may be portrayed precisely by the ability of the genre to trace a private consciousness in its personal and secluded response to the world, drama, which customarily focuses relations to the external world through the interplay of a character's responses to other men or women, and which depends therefore upon the ability of spoken language to convey both the burden of these relations and a character's private thoughts, is placed under greater strain, especially when, as Georg Lukács points out, 'actions manifested in the external world now fail to account for the whole man, who in turn is not able to arrive at an action revelatory of his entire self'. ${ }^{23}$ Unlike previous forms of drama in which a character's words or actions would be understood by at least some of those who heard or saw them, both on stage and/or in the auditorium (thus, even in hostile Elsinore, Hamlet had confidence in his confidant, and knew he would be rightly valued and regarded by Horatio), the lack of a common language and a shared perception of the world in the late nineteenth century now inhibited such direct communication. Even if a character were to find the rare words capable of expressing what is essential to him (or her: Hedda Gabler's desperate attempt at articulating, in her references to the vine-leaves in Løvborg's hair, the values she is unable to 
live by is a typical case, as is the incomprehension with which she is viewed by her husband and Judge Brack following her suicide), 'these words will at any rate go unheard past the spirits of others, or reach them with meaning transformed'. ${ }^{24}$ Hence the notion which is continually advanced by Beckett's characters and frequently argued by Strindberg in (for instance) The Ghost Sonata, that true meaning resides in silence that 'can conceal nothing' and where 'you can hear thoughts and see the past' [SV 58, 205], a notion that was expressed most pointedly by Maeterlinck in an essay in Le Trésor des humbles (1896), of which Strindberg thought so highly that he translated it into Swedish for his third wife, the actress Harriet Bosse. Maeterlinck's essay formulates the programme for a drame statique such as Beckett has since realized: 'It is idle to think that, by means of words, any real communication can ever pass from one man to another... words can never express the real, special relationship that exists between two beings. ${ }^{25}$

Moreover, as Peter Szondi argued, in his provocative thesis, Theorie des moderne Dramas (Frankfurt, 1956), what is involved in this process is in many respects a dialectical progression whereby elements which first arrive in the domain of content as a response to the historical situation become the defining formal basis of the later drama. Thus the increasing isolation and separation of characters, one from another, and their apparent inability to communicate with each other in Strindberg, Maeterlinck or Chekhov, is inscribed as the new formal orthodoxy in the work of Beckett and Pinter.

One strand of this process can be observed in the role played by the setting in each of these plays, where the sequestration of the characters within a single scene, the restrictions this imposes upon possible action, and the potentially undramatic isolation they endure (with Alice and Edgar abandoned by their servants and cut off from the other islanders anticipating the lonely and depleted world of Endgame, whose slow extinction is recorded in Hamm's story), identifies both plays as examples of a recurring form of cellular modern drama in which the physical limitations imposed upon the characters are matched by the formal structures each dramatist employs. ${ }^{26}$

It was in fact Naturalism which stimulated a renewal of interest in the scenic image. Once men were regarded as the products of their heredity and environment, the setting could no longer remain only a more-or-less stylized frame for the dramatic action. It had now to play a role comparable to the one performed by the author's descriptions of the milieu in the naturalist novel, which were conceived as an essential key to an understanding of the characters. Indeed, the setting almost became another character, as vital as the figures on stage and generally more able than they to influence events. Most frequently an interior, that familiar room with its fourth wall removed to expose the intimate lives of its inhabitants to view, this setting might well represent a reduction 
in what the theatre portrayed from the universal stage of (say) medieval drama to the confinement of the modern world. In its most accomplished manifestations, however (for instance, in those settings devised by lbsen for his dramas of contemporary life which John Northam has shown to be an integral part of the action of the play), ${ }^{27}$ it conveyed a tangible, living presence which Raymond Williams plays upon in remarking that 'They were, in the fullest sense, living rooms: places made to live in in certain ways: environments which both reflected and influenced their possibilities of life. ${ }^{28}$

Furthermore, these rooms not only soaked into the lives of those who lived in them, and afforded their customary inhabitants an appropriate habitat with which they merged and where they were territorially at home (hence the inevitability of Miss Julie's downfall when she strays onto unfamiliar terrain, in the servant-dominated kitchen), they also emerged as the most powerful, active elements in a drama in which the human figures became increasingly passive, since it was through this material environment that the underlying natural and social relationships which acted upon the lives of the characters which Naturalism depicted were rendered dramatically. Moreover, if (as Williams goes on to suggest) this generally private family interior is 'predominantly shown as a trap', it is because it is not merely 'the centre of significant immediate relations' - that lattice work of personal relationships between characters which Ibsen and Strindberg analysed so indefatigably and acutely - but the nexus of those 'larger determining forces operating beyond it, to be looked at from the window or to arrive as messages which would reshape these lives'. ${ }^{29}$ For within or behind these late-nineteenth-century dramas of private lives lies that distinction between living space and work place, between the domain of reality operating in the latter and what Walter Benjamin called the private citizen's 'box in the world theatre', ${ }^{30}$ that drawing room where, as Ibsen and Strindberg both demonstrated (ironically in a theatre which aspired to an illusion of reality), illusion was fostered.

But at the end of the century, in The Dance of Death as in Munch's paintings or Schoenberg's first claustrophobic atonal works, which shortly followed, the interior as the domain of private illusion and painful memory, inhabited by figures who sit like prisoners behind doors they have often closed upon themselves in their unwillingness to confront the truth, becomes the nightmarish scene of these characters' inner lives. This is the process that comes to light in The Pelican or lbsen's John Gabriel Borkman, in which the home has already become a prison; which is continued in a succession of major plays, of which Pirandello's Enrico Quatro (1922), Sartre's Les séquestres d'Altona (1959) and Huis clos (1945), and O'Neill's Mourning Becomes Electra (1931) are only four of the most prominent; and which is now discernable in the series of abodes (no longer for living, but for dying in) which make up 
Beckett's universe, from 'the familiar chamber. At the far end a window. On the right the indispensable door', ${ }^{31}$ observed in Ghost Trio, to the more peculiar residences of Winnie's heap of sand in Happy Days, the urns in Play, Krapp's den, the dustbins in Endgame or Clov's chess square of a kitchen, 'ten feet by ten feet by ten feet' [p. 12].

It is, of course, not difficult to relate this process to those models of the mind's activity currently being established by Freud, where a topographical metaphor comprising the cellar, living room and attic of an average bourgeois dwelling house seems quite appropriate. And indeed there is already, in The Wild Duck (1884) in the late Naturalism to which Freud was in fact deeply indebted for the direction of his own project, an attempt to distinguish visually between the oneiric realm of the attic as a timeless universe of the imagination resembling the world of dreams, the mundane living room in which the Ekdals conduct their everyday relationships, and the drunken appetites let loose downstairs. What occurs alongside the withdrawal behind closed doors from John Gabriel Borkman (1896) onwards is thus a foregrounding of this inner landscape as the dramatist responded to the increasing fin-de-siècle preoccupation with what was variously called 'the soul', 'l'âme', 'Die Seele', 'själen' or 'sjælen', and moved from the visible to the invisible in pursuit of what Knut Hamsun described as 'the unconscious and even today almost totally uninterpreted life of the soul'. ${ }^{32}$

Thus it was in keeping with this trend that when Reinhardt chose to open his Kammerspiele in 1906 with a production of Ghosts he should appoint 'der Seelenmaler' (the soul-painter), Edvard Munch, to design the set for what had hitherto been regarded as the quintessentially naturalist stage drama. The interior into which the spectator was now invited to look was no longer a room but a personal and unconscious world of dreams and nightmares, and the way was open for a conception of the theatre as what Ionesco would later term 'the projection onto the stage of the world within', adding: 'it is in my dreams, my anguish, my dark desires, my inner contradictions that I reserve the right to find the stuff of my plays' ${ }^{33}$

But what is particularly to the point here is that those works in which this process is carried furthest, where the Chekhovian or Strindbergian concern with the failure of social communication, tedium and estrangement are, as it were, distilled in the alembic of form, come to resemble the rotunda in which Hamm and Clov are confined, hermetically sealed to the world without. With its self-conscious awareness of itself as a dramatic text, Beckett's theatre - and Endgame in particular - refers not to a world elsewhere but to itself. Even in chamber plays like The Ghost Sonata and The Pelican the text, however loaded with significance and suggestive power, points directly back to the recognizable social context which underlies the events of the drama - the crisis of bourgeois family relationships in The Pelican, for example, and the more 
extensive network of deception and corruption which sustains a society where Hummel's vampirism functions according to modern capitalist methods of psychological and economic exploitation, in The Ghost Sonata. Vestiges of this approach remain in Endgame, notably in Hamm's laboriously composed and unreliable narrative, but like the way in which the play treats another of the standard topics of bourgeois drama, the conflict between the generations ('Accursed progenitor... Why did you engender me?' [pp. 15, 35]), it is done schematically, the information the text affords pointing not outwards towards the world but inwards upon itself, where each detail adds a further item to the rules of the game. The father-son or master-servant relationship of Hamm and Clov weighs no more heavily in the course of the evening than that one of them cannot sit nor the other stand. And where the universalizing thrust of Strindberg's plays is to establish the general social relevance of what is depicted on stage ('Secrets like these are to be found in every home' [XV, 354; 2, 735], he insists, in a letter introducing The Ghost Sonata to his German translator, Emil Schering), the pathos generated by Beckett's text is directed to a common natural predicament: 'She was bonny once.... We too were bonny - once. It's a rare thing not to have been bonny - once' [p. 31].

Thus the event dramatized in Endgame neither takes place offstage (like the sale of the estate in The Cherry Orchard) nor is enacted on it: the event is the text itself and its own performance - the weary end of a game in which the players are painfully aware of the conventions governing stage dialogue in a theatre where no communication is possible. 'Something is taking its course,' Clov remarks portentously [p. 17], but what little linear movement that remained in The Dance of Death is abandoned here. There is no rising action nor falling action for, as Richard Goldman remarks, 'all is fallen at the play's opening. ${ }^{34}$ The first tableau is the last one, or rather, poised to depart Clov remains on stage, in position to recommence the play the following night. As Estragon remarked perceptively, on a previous occasion: 'Nothing happens, nobody comes, nobody goes, it's awful'. ${ }^{35}$ Although Clov perceives a boy outside, the latter never makes his way onto the stage where, throughout the play, 'there has not been a change of heart, mind, situation, venue [and the fact] that we are no closer to a reasoned grasp on the characters' natures or the meaning of what they enact, makes us wonder if it is truly a drama we are looking at - a work that unfolds in time and space.' 'Do we not feel,' Goldman concludes by asking, 'that we are in the presence of a linguistic form that nevertheless suggests the properties of non-linguistic forms - painting and music?'. ${ }^{36}$

Certainly Beckett has found it easier, as in the Three Dialogues with Georges Duthuit, to discuss his own situation in terms of abstract painting, and the musical analogy, already relevant to the thematically organized A Dream Play or to the Chamber Plays, in whose collective title the notion of music is deftly 
merged with a sense of confined inner space, is likewise relevant to Beckett's theatre for small groups of players or solo performance, a theatre in which, by his own account, he is searching for 'the kind of form that you find in music, for example, where themes occur'. ${ }^{37}$

Moreover, in both his last pieces for the theatre and in his own productions of the earlier plays, Beckett stressed both their musical nature and the composition of a stage image ideally apprehended in a moment of time and left to resonate in the spectator's mind.$^{38}$ Nevertheless, this theatre of stasis, of isolation and non-communication remains the descendant of that earlier, seemingly more vigorous theatre, in which these subjects first manifested themselves as a matter of acute concern. And this is not only because of the way in which Beckett's plays evoke Maeterlinck's haunting images of the blind man immobile in his chair and the menacing closed door, or Strindberg's Mummy become a reified turn of phrase as the old parrot she resembles in The Ghost Sonata, much as Nagg and Nell are the decrepit trash of Endgame: rather, it remains pertinent, given Szondi's insight into the way that concerns first made themselves felt in drama as a matter of content become questions of form in the following period, to perceive that alongside the music hall, Yeats, Racine, Jarry and all the other influences that have been discerned in Beckett's theatre, there remains a link with Naturalism.

For although in a radically reduced and depleted state, this theatre is ultimately an epigone of late-nineteenth-century drama. Beyond the similarities already adduced here between The Dance of Death and Endgame, the latter, with its succession of ends and the steady removal of its basic props (nature, biscuits, pap, coffins, etc.) epitomizes, even parodies, the 'falling curve' common to many naturalist works (The Father, Miss Julie, Germinal, L'Assommoir, Germinie Lacerteux, Niels Lyhne) to which Rilke once drew attention in his comments on J. P. Jacobsen's classic naturalist novel, Fru Marie Grubbe (1876). ${ }^{39}$ Life on what Krapp calls 'this old muckball', ${ }^{40}$ in a world without transcendence where personal decay parallels decline and fall, conjures up throughout Beckett's work images in keeping with Edgar's initial conviction that 'once the [human] mechanism's done for... there's hardly so much as a barrowload of muck to tip on the garden' [SV 44, 42]. In what Beckett's Molloy described as 'a world collapsing endlessly... a world at an end', 41 and which Lucky, in Waiting for Godot, perceived as a place where man 'in spite of the strides of alimentation and defecation is seen to waste and pine' in a universe that 'for reasons unknown' continues to 'shrink and dwindle, ${ }^{42}$ the naturalist writer would in fact recognize a familiar landscape. However, whereas Edgar sought to console himself for the absence of meaning in this malodorous universe by inserting himself into the cycle of continuing process of new life from death, Beckett's creatures exist in a situation where, however 
decrepit they become, they cannot obtain their release. The naturalist at least believed, like Jacobsen's hero in Niels Lyhne (1880) that there was an end, that it was possible 'to die the death, the bitter death'. ${ }^{43}$ Beckett's figures remain denizens of a text that goes on revolving, both on the page and in the mind. 


\section{8. 'Spela den så att Pontoppidan och Fru Nansen få blåskatarrh': Strindberg's Correspondence with Actors and Directors}

In October 1902 Max Reinhardt staged Strindberg's Crimes and Crimes at the Kleines Theater in Berlin, with Emanuel Reicher as Maurice and Gertrud Eysoldt as Henriette. It was Reinhardt's third major Strindberg production in twelve months and both these performers were also experienced at acting in Strindberg's plays. Anticipating a success, his German translator, Emil Schering, therefore encouraged him to travel down and see the production for himself. However, Strindberg's response was characteristically discouraging: '([I'm] grateful for the high hopes you send me every day,' he told Schering,

and look to see them realized in due course. My going to Berlin would be to study and to get some new ideas, for here we're sunk in a winter sleep all year round, and I have now lived up the entire supply I brought home from abroad last time. But you surely never believed I would go to Berlin to be lionized or 'perform' (like Bjørnson!). I certainly believe I owe it to the actors to see a performance, from a concealed seat, one evening when no one in the public is aware I am there, and even though it is a torture to see my shadows and hear my words, I shall do my duty... I am opposed to everything of a public nature, quite pathologically so! [XIV, 220]

To anyone familiar with Strindberg's correspondence this response will come as no surprise. For while he was always pleased to travel the world in pursuit of the capital of experience that he exploited in his writings, he was unwilling to expose himself to the paying public in person. Shy and frequently tonguetied in public gatherings, he left his writing to speak for him, and a director or impresario (Schering at this time enjoyed playing the latter role alongside that of translator) had to be prepared for Strindberg to cry off an opening night. At best he might attend a dress rehearsal and follow up his visit with a formal note of thanks to those involved in mounting the production. 
Such notes form only a small proportion of the some 9,000 items in Strindberg's extant correspondence. The sheer volume of his letter writing, which in this respect represents his principal genre, is to be accounted for only in part by the fact that for many years he lived abroad during the 1880s and 1890 s. In fact, the volume of his correspondence in no way diminished when he returned to Sweden, either in 1889 or again in 1898, and it is clear that from an early stage in his career letter writing fulfilled a vital need for selfexpression, one which could only be adequately satisfied in this immediate fashion. Moreover, for Strindberg, the private letter was not only the most honest and individual form of communication, which implied spontaneity, naturalness, and originality; it was also the basis for other kinds of writing, whose affinity with the personal letter seemingly masked for him the element of artifice and stereotype present in all written compositions.

At first sight Strindberg's epistolary aesthetic may recall Stendhal's approach to autobiographical prose, which he sometimes regards as a form of letter: 'Je me suis imposé d'écrire ces souvenirs à vingt pages par séance, comme une lettre', he writes, in Les Souvenirs d'egotisme, and again, 'J'écris ceci, sans mentir j'éspère, avec plaisir comme une lettre à un ami', in Chapter One of La Vie de Henry Brulard. ${ }^{1}$ But Strindberg's practice is very much more far-reaching. Just how far-reaching is most clearly articulated in the lengthy epistle on writing with which he initiates his correspondence with his first wife, Siri von Essen, in 1875 . 'For you, writing is simply a matter of remembering' [I, 193; 1, 41], he tells her, and goes on to demonstrate how she may arrive at a work of literature by taking and dating a sheet of stationary, and addressing on it all she cannot say aloud to a dear friend. Then, by the simple expedient of removing the date, the superscription and the signature the text of this and other such 'letters' to which she has confided herself may be published as a book. Again, in 1882, he tells his sister, Elisabeth, 'If your heart is full and you cannot speak, then write! Every educated person can write, that is, commit their thoughts to paper. You can write letters; a good and true book is a letter. Writing is not inventing, making up something that has never happened; to write is to relate what one has lived' [Ill, 41; 1, 97]. And in 1907 letter writing remains the touchstone for that immediate and truthful form of writing to which he aspires when he seeks to console Schering for the break up of his (Schering's) marriage by advising him to 'Write yourself, write out your pain! You write such masterly letters! and are thus a writer' [XVI, 30; 2, 748]. Or, as he writes in A Blue Book, of his own published work and with the outrage it so frequently occasions uppermost in his mind: 'I confided (anfortrodde) it to the silent, printed word on the white paper. It was a confidential communication; and he who betrayed it was a traitor. Our books are produced in order to be read silently, to be whispered in [the reader's] ear' [SS 48, 941-2]. ${ }^{2}$ 
Nevertheless, Strindberg's response in this otherwise practical letter to Schering about Reinhardt's production of Crimes and Crimes touches upon a notion that lies behind much of his writing in general, and his letter writing in particular, namely that where he is concerned social intercourse is 'a web of hypocrisy and lies' [SS 17, 68] which people deploy 'only with the object of deceiving each other' [SS 48, 1061], and that in spoken discourse one therefore runs the risk of losing one's identity. Through shyness or social convention one is unable to represent oneself accurately when speaking; this can only be done in writing. Moreover, 'our tongues and the words they speak are so sullied by everyday use that they cannot say aloud what the pen says silently' [SS 47, 731]. Strindberg is in fact deeply suspicious of the notion of a full and present speech, embodied in the person of the speaker, and likewise of a presence that is immediately recoverable from language as spoken, a language that is denied transparency and truth by the need always to accommodate oneself to one's interlocutor. For Strindberg, the self is dissolved or frittered away in speech; the speaker does not commit himself to his utterance but dissipates himself in the impermanence of the spoken word; hence he prefers to withdraw from social intercourse and reappropriate the presence that eludes him in speech in writing, most immediately in what that experienced man of letters, Samuel Richardson, calls, 'the converse of the pen[.] The pen that makes distance, presence; and brings back to sweet remembrance all the delights of presence; which makes even presence but body, while absence becomes the soul'. ${ }^{4}$ Thus 'Strindberg prefers the solitary, secondary, invented mode of writing, which arrests, fixes, abstracts from, and supplements experience, a mode of communication which eschews the immediacy and disorder of dialogue, and which is characterized by a double absence, or occultation, wherein the reader is absent from the writing of the book and the writer from its reading, to what is regarded, if only because of the anteriority of speech to writing in the individual's life and in history, as the primary, natural, even divine mode of communication in which the voice, borne by the breath, and guaranteed by facial expression, gesture, tone and inflection, signifies the presence of the speaker and his companions to himself and to others, in an interlocutory situation that binds voice and ear in the here and now'. As he tells Schering three days later, when he is still seeking to justify his absence from Berlin, 'My writings are myself (Mina skrifter är jag!) and any attempt to exhibit himself in public would be a form of 'prostitution' [XIV, 223; 2, 698].

The private letter, which straddles the gulf between presence and absence, is thus Strindberg's preferred genre, alongside the theatre in which the interlocutory situation described here may be realized by proxy. And consequently his reluctance to visit the theatre, which several of his biographers have chronicled, does not mean (as they sometimes argue) that he showed 
little concern for the practicalities of performance, or even that he was so out of touch with what could be staged that he wrote such theatrically impossible works as A Dream Play and The Ghost Sonata. Indeed, the dominant trend of Strindberg studies has been so preoccupied with questions of biography and literary history that the theatrical dimension, and in particular its practical aspect, has frequently been lost.

In fact, alongside the Open Letters to the Intimate Theatre, ${ }^{6}$ where characteristically he appears before his theatre company in print rather than in person, Strindberg's letters provide a valuable corrective to this point of view. Certainly, there are periods when he has little or nothing to do with the theatre, and several volumes in his correspondence $(5,11$, and 12 , for instance) feature no letters to actors or directors. ${ }^{7}$ But just as he wrote more plays when there was a possibility of having them performed so he normally wrote to actors and directors only when they performed in them or were considering putting them on stage. As he tells August Falck, in 1910: 'If a new theatre really does come off at Birger Jarlsgatan there will doubtless be some new plays, should they be needed' [XIX, 12]. For much of his life Strindberg was essentially his own agent and P.R. man; he did not wish to write superfluously; and it is hardly surprising, therefore, that the majority of these letters should be written to the moment, when there was the prospect of performance or he had a new work that he was seeking to place. With the exception of a few items to Frans Hedberg, Ludvig Josephson, and August Lindberg in the 1870s and early 1880s there is thus little before a flurry of activity in 1888-89 when he sought to establish his Scandinavian Experimental Theatre in Copenhagen, a further group around the turn of the century when he has a whole new drama to be performed and certain works, To Damascus I, Gustav Vasa, and Erik XIV, enter the repertoire, and thirdly, and most especially, the long sequence of letters that he addressed to August Falck and the company of the Intimate Theatre between 1907 and 1910 when he is occupied with theatre business of all kinds, from ticket prices and the requisitioning of props to the staging, decor, costuming and acting of his plays. Then, quite literally, he gives notes to the cast in the form of notes, and we may thank his reluctance to appear in person for many of his most perceptive comments on the theatre. For as he writes to the young actor, Anton de Verdier: 'If you would let your comrades read this, that would save me repeating myself. There are perhaps some observations [here] that others might find useful! I am no speaker, therefore I write!' [XVII, 22]. ${ }^{8}$

Although he is on a friendly footing with a number of the actors to whom he writes, and some, like August Lindberg, Tore Svennberg, or Ivar Nilsson, even become familiars at his Beethoven evenings in Blå tornet and elsewhere, these letters do not have the introspective quality of his correspondence with (say) Torsten Hedlund during 1895 and 1896 (and it is important to remember 
that such a correspondence as the one he conducted with Hedlund need not be with someone who is a close personal friend: Strindberg, of course, never met Hedlund); nor do they share in the intellectual adventure of his exchanges with Leopold Littmansson during the 1890s or the burlesque humour that characterizes several of his letters to Carl Larsson, the energy of his correspondence with Verner von Heidenstam, the confessional letters that he addressed to Bjørnson, or even the pathos regarding money matters in many of his letters to Albert or Karl Otto Bonnier. Only when he is writing to Harriet Bosse do his letters to a performer attain this kind of level, but then it is rarely to the practising actress that he addresses himself: it is rather the unfolding drama of his private life that generally concerns him here, not the drama as such, and the same applies to his correspondence with Siri von Essen or their second daughter, Greta, where theatre business also becomes an occasional topic of importance.

Nor does he normally allow the personal peccadilloes that enliven much of his correspondence to interfere with his advice to a performer. It is therefore exceptional when he writes to the Danish playwright and actress, Nathalie Larsen: 'But play Miss Julie as it should be played - not as a sentimental vicarage miss but an emancipated (= prostituted) modern woman of the world. Show your passions, if you have any, otherwise: act them!' [VIII, 210; 1, 347] or when he instructs Siri Von Essen to perform The Stronger 'so that Pontoppidan and Fru Nansen get cystitis' (så att Pontoppidan och Fru Nansen få blåskatarrh [VII, 263; 1, 263]). Indeed, he rarely devotes much space even to the ideas informing the work he is discussing. In writing to actors or directors, he is more concerned with a play's structure or its effectiveness as theatre, and in particular how the individual parts should be realized. Thus, as soon as he hears that August Falck the elder is to play the Captain in The Father at Nya Teatern in 1887 he immediately sends him a letter full of practical advice, a great deal of which is derived from his experience of the play's Danish première earlier that year, with Hans Riber Hunderup in the title role. Although he disclaims any practical expertise and expresses an unwillingness to interfere in the actor's domain - 'As you know from times past, I haven't much idea of scenic detail, and I'm reluctant to disturb the work of the actors by interfering' - his comments have great practical relevance.

Beginning with a general observation, that the style of the play is 'not tragedy, not comedy, but something in between', and that it should therefore be performed 'as Lindberg performed Ibsen', he focuses on the tempo ('don't take too fast a tempo... Rather let it creep forward quietly, evenly, until it gathers momentum of its own accord towards the last act') and on character, stressing that 'the Captain isn't a coarse soldier, but a scholar who has risen above his profession'. And as with the reference to Lindberg's Ibsen style he feeds Falck 
the names of several Stockholm figures who might be used as templates in preparing the role: 'Think, without copying him, of the late Captain P. v. Möller, a member of the Academy of Letters and History; the painter v. Holst, the philanthropist, v. Koch, etc.' He also gives detailed instructions for the Captain's entry in Act Three, which is precisely visualized ('when he enters in the third act, he is in his shirt sleeves (woollen shirt), has his books under one arm and the saw under the other') and supplies Falck with 'a rewarding moment in Act 3, Scene 1, when she sits at the same secretaire at which the Captain was sitting earlier. If she repeats or makes some gesture of the Captain's (e.g. putting the pen between her lips and saying a line with it there, always assuming the Captain really used that gesture), the contrast will make a fine effect'. Here, the notion of 'hjärnornas kamp' (the battle of the brains) and the unconscious influence of one mind upon another, which the play as a whole explores, is deftly absorbed into a piece of stage business.

Elsewhere in the letter he tips Falck on how to manage the lamp-throwing episode at the end of the second act ('Here we used a wicker lamp; the glass and shade can be fastened with putty so that the lamp may be lifted without the glass falling off, and thrown past Laura's head out through the door, but not before she has exited backwards, so the spectator is left in doubt as to whether or not it has hit her'), and he is particularly perceptive about the casting of Laura's role. 'If Laura is played by a younger and beautiful woman, she should be hard, for her appearance will soften the effect, and her influence over her husband will be motivated in that way. If she is played by someone older, the maternal aspect must be stressed, and the hardness somewhat underplayed' [VI, 337-8; 1, 259-60]. And so aware is he of the way in which an actor's appearance can influence the audience's reception of a role that six days later (this time in a letter to the publisher Claës Looström), he advances the candidature of his old friend Hilma Frankenfelt over a certain Fru Gardt in Laura's role because her type will actually counterbalance the impact of his writing: 'Hilma F[rankenfeldt] would be excellent! The hardboiled, mean, mendacious side of Laura's character would be ennobled by her beauty and elegance, and in contrast to Fru Gardt she would be believable as a Captain's wife, someone who through her feminine charms could have exerted such an influence on her husband' [VI, 349]. Taken together with his advice to Manda Björling concerning the protagonist of Kristina (Queen Christina), namely that 'Even when Kristina is coarse, you must be charming' [XVII, 43], Strindberg here touches upon Stanislavsky's dictum that an actor should always seek the opposite aspects of the role he or she is playing - the young man in the old, for example, or the good woman in the wicked.

What is characteristic in this letter to Falck is Strindberg's attention to detail and the ready confirmation that in thinking about his plays he was also 
visualizing them. In this respect casting is certainly one among several of his recurring preoccupations, not least because, unlike much nineteenth-century theatre practice, he knows that 'a role can never be distributed early enough. In that way, it develops slowly and ripens well' [XIII, 338]. 'I could write a whole chapter about the distribution of roles, which is the touchstone of a director', he tells August Falck's son, and his collaborator with the same name at the Intimate Theatre: 'To be able to recognize an actor's aptitude at a glance and place him in the right slot!' [XVI, 302]. In his first major letter to an actor, written in 1871 to his friend August Dörum, who was to play Orm in the forthcoming première of The Outlaw, he questions the wisdom of much of the other casting, and has the temerity, at this early stage in his career, to seek through Dörum to influence the Royal Theatre and its dramaturg, Frans Hedberg, regarding the disposition of roles. Sometimes, however, his concern is opportunistic. In 1910, for example, he writes temptingly to the great French director of symbolist theatre, Aurélian Lugné-Poë, to offer him 'Reine Christine! Voici un beau rôle pour [votre femme] Suzanne Desprès' [XIX, 218] and in 1900 he approaches the current director of the Stockholm Royal Theater, Nils Personne, with a somewhat disingenuous 'word about the girl's (Eleonora's) role [in Easter]! You know my weakness for Fröken Bosse. I miss in her colleagues the wealth of poetry and "Seriousness" which she possesses; and her childlike figure is well-suited for a girl with a pigtail down her back' [XIII, 335; 2, 666]. Likewise, the following year he remarks to the director Emil Grandinson, apropos The Virgin Bride (Kronbruden), that 'as I've written to Personne, my only condition is that Fröken Bosse gets Kersti'. And then, remembering Bosse's slight stature, he adds, with disarming good sense: 'in order to obtain nice proportions between [their] figures I had in mind Fröken Sjöberg for Brita' [XIV, 49]. However, once Bosse comes to play a central role in Strindberg's life, as well as in his stage works, certain parts are out of bounds to her. Although she created the role of The Lady in the première of To Damascus I in 1900, her subsequent assumption of the role of Strindberg's third wife made it impossible for her to take the same part in a production of To Damascus II or, indeed, in any revival of Part I: 'I have nothing against it being performed, but request that my wife be spared "The Lady", just as she also asks to be excused the same role in Part I, should it be revived!' [XIV, 99].

Normally, however, Strindberg's concern is to match an 'actor's aptitude' to his conception of the role. Thus, in a long correspondence with Grandinson and one of Personne's successors at the new Royal Dramatic Theatre, Knut Michælson, concerning The Last Knight (Siste riddaren, 1909), he is greatly agitated by whom to cast as the younger Sten Sture. Rejecting both the experienced Anders de Wahl and Gösta Hillberg, he argues for August Palme, 'if he's got a slim waist', or Ivar Nilsson, 'if he can be tender' [XVII, 45], and for 
a moment he even has the 'ridiculous notion... that Sture should be portrayed by - Julia Håkonsson!' [XVII, 70], who was best known for her performances in Ibsen's dramas of contemporary life, from Lona Hessel in The Pillars of Society to both the principal women's roles in John Gabriel Borkman and Maja in When We Dead Awaken. Not surprisingly, Grandinson failed to run with this last idea.

However, if the vicissitudes of casting have now lost their urgency for all but the theatre historian, many of Strindberg's other instructions to his actors and directors remain pertinent, both in the immediate context of how his plays might be staged and (as Gösta Bergman has rightly indicated) ${ }^{9}$ as part of the general theatrical revolution that took place around the turn of the century. For, like Gordon Craig, Fuchs, Appia and Meyerhold, Strindberg was then engaged in developing a new, post-naturalist language of the stage which was exclusively and uniquely theatrical. These instructions do not amount to anything like the system that Stanislavsky was currently uncovering in Moscow, nor do they argue a single-minded theory of acting as (say) Diderot does in Le Paradoxe sur le comédien: they are too diffuse and written to the moment. Nevertheless, fragmentary as they are they suggest that if Strindberg visited the theatre only rarely, he made good use of his time there.

$\mathrm{He}$ is, for example, aware from the outset that theatrical performance involves a collaboration between performers and audience, and that the actor needs to find ways of entering into a 'rapport with those before whom she is speaking' [XIV, 174]. The actor must be in 'continuous contact with the public' [Ill, 12], he tells Siri von Essen in 1882, and in the previously quoted letter to Dörum on The Outlaw, he makes a serious point in jocular fashion when he advises the latter:

... don't overact! Understand me - your spectator is an idle dog who wants everything explained to him straight away - he can't be bothered to think very much for himself - if he has to, he starts yawning and gets bored! But he's amused by hints - this is how it works: if you make a slight gesture, a mere nuance of facial expression, he'll understand it well enough - as long as he only has to think a bit - then he'll be delighted with himself for being so quick on the uptake, and that's when he turns to his neighbour and digs him in the ribs - as much as to say, 'did you get that?' [I, 81;1, 17]

The audience must be engaged in the performance, and the long, one-act form of drama which Strindberg favoured from The Outlaw to Miss Julie and the Chamber Plays is in fact a ploy to gain and retain its attention. In a long play like To Damascus I, for example, he argues that the audience need to be kept in their seats for as long as possible: 'let them out to discuss things, and arm themselves for conscious resistance, and we can lose the play' [XIII, 322-3; 2, 
665], he tells the director, Grandinson. Hence 'the scene changes up to that point [i.e. the central asylum scene, following which an interval is permissable] must take place in blackout, but without a curtain. As soon as the curtain comes down, an audience gives itself a shake and rejects what it's seen' [p. 323]. On the other hand, where the performers experience technical problems even in a relatively short play, such as The Bond, Strindberg recognizes the need to assist them with an interval. Following a dress rehearsal of that play at the Intimate Theatre, he wrote to Falck: 'As a result of yesterday morning: you must have an interval in The Bond, for you will tire, Fröken Flygare will tire, the audience will tire! But with an interval you and Fr. Flygare can speak more slowly, the audience catch what is said better, and the play will profit by it' [XVI, 165].

Although the way in which the playwright has constructed his play may assist the actor, it is the latter who is immediately responsible for gripping the audience's attention. Most of Strindberg's advice is therefore directed to him. And while he could, on occasion, be cavalier (thus to the inexperienced Viggo Schiwe, who was to appear as Herr Y in the Scandinavian Experimental Theatre's production of Pariah (Paria), and in desperate need of some direction, Strindberg merely advised: 'act with some inspiration - improvise like the Italians - and let us see if the play holds!... Think yourself into to the role and it will come of its own accord in performance but not before' (VII, 269)), he was generally specific and pertinent. Even his seemingly casual remark to Schiwe is given some sense when placed alongside a later comment to the more experienced Manda Björling, to whom he writes: 'rehearse the role in your memory first, then the expression and the mood will come by itself. I have never understood what to "study" a role means, because in a studied role the work and design are visible' [XVI, 191]. What he, like Stanislavsky or any good modern director, was seeking to avoid was the slentrian and the mechanical; the question was how to assist the actor in finding his or her character in a well-written role.

To this end Strindberg argued from an early stage in favour of what Stanislavsky codified as affective, or emotion, memory. He asks Dörum to 'ask [Alfred Hansson] to cast about in his memory for some deep sorrow - really deep, if he's been fortunate enough to experience such a thing - and ask him to call it to mind when he says the word "Gunlöd"!' [I, 80; 1, 16]. The actor, in short, is to bring his or her own experience to the role, and find in memory the appropriate key with which to inform the part at a particular moment. At other times, in a theatre that was only now freeing itself from the collation of individual parts at the expense of the play as a whole, he would (like Ibsen) ${ }^{10}$ tell an actor to 'see what the other roles say about you; after all they give you your character' [XVI, 173], a point which is of even greater relevance in a drama 
like Strindberg's, where character was presented as multiple and relationships between the characters shifted according to their knowledge of each other.

Again like Stanislavsky he was aware of the importance of concentration, and the need for ensemble playing. Thus he advises Svea Åhman, who was to appear as the wife in Playing with Fire to: 'creep inside the role, but also into the mood which prevails on stage when you make your entrance; that's why it is a good thing to wait for your cue in the wings, listen to the intonation of those on stage, catch the mood and tone; and then make your entry; but not straight out of the dressing-room and its small talk' [XVI, 171]. He even tells Falck, apropos his production of Easter, to encourage a kind of hypnosis, a form of concentration in which one character continues to exert an influence over his fellow performers even when he is not in stage:

Once more: pay attention to the exits. An actor who rushes out takes with him something of the mood of those still on stage: but he should leave something of his role behind. And when he is off stage, he should not cut the thread by talking or doing something else. If he has a principal role he should absolutely not lose contact while he is off stage. His thoughts should remain on stage and lead the action from without; his soul should remain there although his body exits. Those who remain feel this, and when they talk about him the audience should seem to see him. [XVI, 278]

Strindberg also authorizes the actor to play against what might appear the dominant tone of the text. Thus, Hunderup in the role of Gustaf in Creditors is instructed to 'now act the whole part playfully and good-naturedly, as someone who is superior can... so that there is some truth in Tekla's words, when she finds Gustaf "so free from moralizing and preaching"... Therefore: Gustaf as the cat playing with the mouse before he bites him! Never nasty, never moral! never preaching!' [VII, 259]. Likewise, Harriet Bosse as The Lady in To Damascus I gets the important note: 'It was great and beautiful (Damascus), although I had imagined the character somewhat lighter, with little touches of mischief and with more expansiveness. A little of Puck! - Those were my first words to you! and will be my last!' [XIII, 337; 2, 668]. In every case he stresses the individual over the stock character, and is insistent on the avoidance of cliché. Svea Åhman, for example, is given copious advice on how to play the wife in Playing with Fire, ending with the assurance, 'One further bold trick, and you will be saved: Throw away that red wig from 1870, and have black Cléo de Mérode hair... and you will feel like another person in the role!' [XVI, 168]. Meanwhile Falck, who is appearing in Pariah, is told: 'Don't wear a red beard and hair in Pariah, as characterization it's over the top (= provincial). Villains seldom have red hair. Better take a wishy-washy blond (dirty)... but keep the cigar-end and thumb it, chew it' [XVI, 186]. 
Above all, however, Strindberg is concerned with movement and speech, and in particular those moments when they are in symbiosis. Obvious clumsiness on stage is always to be avoided. Thus Nathalie Larsen is told not to walk with her feet splayed [VII, 254] and he is severe on anyone whose arms hang limply by their sides. In this respect, as when he tells Greta Strindberg to 'Pay attention to your walk; elasticate the sole from heel to toe, and don't lift the foot straight up rigidly. Never run, don't waddle... and don't mince on stage' [XVIII, 195, 228], he recalls Goethe's concern with stage propriety in his notes to his Weimar actors: certain things are simply not done on stage, as when he tells Manda Björling, to avoid being 'cross' in Sir Bengt's Wife (Herr Bengts hustru) since it is unbecoming a woman [XVI, 191]! More significantly, however (and this is an observation unusual in a non-practitioner), Strindberg is aware that 'When your whole being has the role in it, it lives in every muscle, nerve and sinew. The gesture follows automatically with the word; not a muscle lacks life... the hands follow the movements of the mouth if the words come from the heart, so one doesn't think of it' [XVI, 278]. And again, this time to Helge Wahlgren: 'eat yourself inside the role, so that the gesture is born with the word' [XVII, 87], a remark that perhaps unfairly implies precedence to the word over gesture when, as the practising actor is aware, it is generally more a case of speech accompanying or following on from gesture and movement. What characterizes the actable script, like The Father or Miss Julie, is its 'potential gesturality', ${ }^{11}$ a linguistic text with these gestures and movements implicit in it.

It is here, where voice and speech are concerned, that Strindberg appears to be at his most conventional. Or certainly, at his most prescriptive. And yet appearances may mislead. When writing to his daughter Greta or to members of the Intimate Theatre he is evidently concerned with what would once have been called their elocution, and therefore takes them to task over their 'phrasing or musical punctuation, that is the stressing of the more important words and the withholding of unimportant ones together with a proper dividing up of the phrase; modulating or observation of raising and lowering, accelerando (speeding up) and ritardando (slowing down), pausing, legato, and staccato' [XVII, 18 - Strindberg's emphases]. The musical terms employed here are typical of the period (Meyerhold, for example, uses a similar vocabulary to describe The Cherry Orchard) 12 and 'legato' ('Det stora legato' [XVI, 166 - the great legato], as he describes it to Falck) and 'staccato' become Strindberg's shorthand for the desirable and the undesirable. In everyday conversation speech becomes careless and jerky, and this cannot be transferred to the stage, even in the interests of realism, without detracting from the performance and its reception by an audience. As he tells Greta, 'Don't chat, but speak, on a big scale and with breadth; bind (sing) words and periods, and don't chop 
(staccato)!' [XVIII, 167 - Strindberg's emphasis]. One must practise either by speaking 'carefully in everyday use' [XVI, 327] or, as in British drama schools some thirty-five years ago, by verse speaking. Thus, when confronted by poor articulation, Strindberg's recurrent recommendation is the poetry of Esaias Tegnér (1782-1846). 'Tell the Prince in Swanwhite to read Tegnér's poetry [aloud] every day, then he'll get the legato' [XVI, 135], he requests Falck. Even Manda Björling is advised to 'Find your natural voice once more, hold on to it, cultivate it by vocalizing poetry (Tegnér)' [XVI, 191] while his inexperienced protegée, Fanny Falkner, is encouraged to 'Exercise your voice everyday with poetry; e.g. Tegnér's Asatiden' [XVII, 112] and Alrik Kjellgren: 'If you will learn Tegnér's "Aolsång" by heart and come and recite it for me, I shall tell you the secrets of speech... You are a splendid actor, born to the stage. But now it's time you became perfect! You speak properly, where tone and mood are concerned, but it must sound beautiful!' [XVI, 332]. But in almost every instance here he is, of course, writing to inexperienced and even untrained performers, whose voice control is likely to be their weakest point. Pedantic and old-fashioned as these remarks appear, it is therefore hardly surprising that audibility and articulation should be of such concern to Strindberg, and he rarely comments on his speech when writing to an experienced performer like Falck.

$\mathrm{He}$, on the other hand, is taken to task because in The Pelican he "shouted and made a racket", went over the top, it's what one calls provincial... The modern or new art of acting is: not to gesticulate and not to shout.... But to be inside the role, behind the proscenium, keeping the mood [of the performance]' [XVI, 111]. Here Strindberg touches upon what has become, with Stanislavsky, a key notion of acting in the modern realistic theatre, namely the mystical gulf that separates the stage, on which the actor appears to have no knowledge of the audience, from the auditorium. In this theatre the art of acting resides in concealing its art so that the actors appear to behave quite naturally. Thus, the performer in a play like Miss Julie must appear oblivious of the public and yet, as Stanislavsky also knew, must operate in circles of concentration that admit a lateral awareness of an audience that would otherwise be excluded from the action, and lost. As any practitioner knows, the dividing line is a tine one, and Strindberg draws it with some precision in a long letter to Falck, in which he defines the difference between a performance that crudely draws attention to itself, one that loses itself in introspection on stage, and one that finds the appropriate balance.

Now I have finally discovered that maximum illusion is achieved if one does not think of the audience, but acts [within the framework of] the stage. That's what Kjellgren did as Benjamin and Falck as Lindqvist. Flygare sometimes had to speak with her eyes directed out front, when 
the words did not suffice in themselves, and she did that well. For a while Rydell put on an act, or played to the gallery; that appeared old-fashioned and she became detached from the frame. De [V]erdier was just right. One can turn one's face towards the auditorium without 'speaking to the audience'. That's what V. did; he directed his performance outwards, but kept himself behind the curtain; that's what matters. [XVI, 279]

Or, as he tells Manda Björling, as if it were the simplest thing in the world, 'speak to the mass of people out there at the same time as you are within the scene, on the stage' [XVII, 12]. What, of course, he does not say, presumably because he does not know, is how to do this; that remains the prerogative of the true practitioner.

However, what is admirable about Strindberg's correspondence with actors and directors is his flexibility and his willingness to learn. For example, although he argued for the primacy of the spoken word ("In the beginning was the word!" Yes, the word, the spoken word is everything!' [XVI, 304]), he was generally prepared to adapt his texts in the light of experience. Thus, having at last seen Master Olof staged in 1881, he acknowledged that it needed shortening and wrote at once to his director, Ludvig Josephson, to suggest that he cut part of the tavern scene at the beginning of Act Two, the nobleman's harangue in Act Three, and the churchyard scene at the beginning of Act Five $[11,340]$. Regarding the Swedish première of The Father he gave August Falck some cuts and told him, 'Cut more if you want. You will no doubt hear during rehearsal what jars' [VI, 337] while during rehearsals of The Stronger in 1889 he told Siri von Essen to 'change any phrases that don't come naturally' [VII, 263; $1,307]$. Thus, although the text for Strindberg was crucial and the theatre he finally acquired in 1907 was a playwright's theatre, devoted almost exclusively to his own works, he was ready to adapt to prevailing circumstances and take the exigencies of staging into account. Indeed, the latter sometimes encouraged him to break with current practice and experiment. For example, anticipating problems with The Great Highway he writes to Falck, in January 1910:

If you are afraid of the scene with the child in The Great Highway or children are forbidden, then don't cut it, but proceed as follows; using the monodrama method.

You say: 'Here comes the sovereign -' (As it happens she doesn't come.) Then you say: 'I've experienced this scene - before - somewhere She comes - and says: Go quietly, etc.'

Then You speak the entire scene, partly as you think it should take place, partly as 'You' have experienced it!

This is an expedient, you see, but it's debatable whether the scene [with you] entirely on your own shouldn't work better, have a greater, more mystical [mera mystisk] effect. [XVIII, 272] 
Monodrama attracted considerable attention around the turn of the century; indeed, Strindberg had already toyed with the genre himself as a vehicle for Harriet Bosse, for whom he set out to adapt a number of works, including Schiller's Maria Stuart, as monodramas. ${ }^{13}$ But it is in his search for this 'more mystical' form of staging that he is at his most revolutionary. And again, as so often happens during the emergence of the modern theatre, it is the need to resolve the problems posed by the practical limitations of the situation in which one is working that occasions the development of new theatre practice. The premises of the Intimate Theatre at Norra Bantorget had room for 161 spectators and the stage itself was a mere 6 metres broad and 4 metres deep. Nor was there room in the wings to store any amount of scenery or the possibility of flying new sets in from above. (Not the least of the theatre's founding problems had to do with health and safety, and in particular the fire regulations.) Thus Falck and Strindberg were soon confronted by technical as well as artistic problems (as if, in the theatre, the two are separable!), and Strindberg's response, which he urged upon his sometimes doubting codirector, derived a great deal from his knowledge of developments elsewhere in Europe - in, for example, the ideas of Edward Gordon Craig, whose On the Art of the Theatre Strindberg had first read in 1905 [XV, 135], and Georg Fuchs' Die Schaubühne der Zukunft [XVII, 238] - and something from his reading about past methods of staging in Herman Ring's Teaterns historia från äldsta till nyaste tid. It was, for example, in Ring that he found the idea for what he called the Molière stage (in reality Abr. Bosse's widely reproduced picture of the farce actors at the Hôtel de Bourgogne in 1630) where a pair of balustrades on either side of the acting area could be used to indicate time and place, and a change of scene, by the removal or addition of one or another decorative prop placed upon them. ${ }^{14}$

But his principal source of inspiration was in fact the practice of working in the theatre itself, of, for instance, seeing for himself how a four-square solidly built set could be replaced by drapes in heavy velvet, on which the lights could play in various colours to achieve both a different sense of perspective and/ or the impression of a change of scene. Hence his enthusiasm for staging The Ghost Sonata, again without an interval, but on a 'dematerialized' stage where a heavy and cumbersome setting has been supplanted by curtains: 'The Mummy, e.g., sits in an opening in the rear curtain as in a closet. It would raise the play up to its plane, which is not the material plane' [XVII, 322]. As he developed his ideas it was therefore continually in the direction of such greater simplicity that he moved, sensing that it was there that he would achieve the impression of 'dematerialization' that was implicit in dramas like A Dream Play and The Ghost Sonata, and which was undermined by the kind of staging conventional in larger theatres at the turn of the century. Seeking to dispense with what 
he calls 'all these theatrical gee-gaws which nowadays engulf the stage'15 at the Royal Dramatic Theatre in Stockholm, he therefore urges on Falck the adoption of a 'permanent set - in the right tone so that it doesn't clash! If we go in for elegant furniture and props, we'll be back on the beaten track again... One table and two chairs! That's the ideal!' [XVI, 232].

This is a recipe that recalls his description of Creditors, at the height of his naturalistic period, as 'better even than Miss Julie, with three characters, one table and two chairs, and no sunrise!' [VII, 105; 1, 281], and in such a simplified staging he argues that even The Father will 'be raised out of its heavy everyday sphere and become a tragedy in the high style; the characters will be elevated, ennobled, and seem to come from another world.... We have sunk back [he tells Falck] to what was called Molander, or realism, naturalism, all of which is over and done with' [XVI, 236], and consequently lost the immediate, uncluttered, dematerialized playing style at which they should be aiming. For, according to Strindberg, the gains for the performer as well as the dramatist in adopting this meticulous but unfussy form of staging are immeasurable: 'With simple sets what matters stands out: the character, the role, speech, expression, gesture... "In the beginning was the word!" Yes, the word, the spoken word is everything!' [XVI, 304; 2, 783]. As Gösta Bergman remarks, of this declaration, 'Strindberg was far removed from Appia's and Craig's speculations about the rhythm of movement and mimic force. In the beginning was the word, not the dance or rhythmic movement. ${ }^{16}$ And yet, like the plays that he had already written for a theatre that was so far unable fully to accommodate them, these letters, notes and sketches to his fellow theatre workers between 1907 and 1910, indicate that in his thinking about the practicalities of staging, Strindberg had indeed crossed the threshold from the nineteenth to the twentieth-century stage. 



\section{From Naturalism to Modernism}





\section{Towards a New Language: Strindberg's Break with Naturalism}

In Strindbergs bildspråk (Strindberg's Imagery), which still remains, even after thirty-five years, the most sensitive and thorough study of Strindberg's language yet published, Karl-Åke Kärnell quotes from a critical commentary on Mallarmé: 'Ce goût des analogies, cette obsession même, était le trait fondamental du caractère de l'homme... Tout pour lui était métaphore, comparaison, image. L'analogie était la façon la plus simple de comprendre... Cette obsession a dû être pénible à la fin. Elle le prit corps et âme; elle domina dans son travail et dans ses loisirs.' Kärnell adds: 'This is a characterization that could be transferred almost word for word to the Strindberg of the 1890s... In fact, of contemporary Swedish writers there can really have been no one whose thoughts were so clearly and unequivocally formulated in a "symbolist" manner as were Strindberg's. ${ }^{1}$

In later years Strindberg appeared himself to have little time for symbolism. Characteristically remarking upon what he took to be the way in which the symbolists employed language to conceal rather than to reveal, to mask rather than, as he was concerned to do throughout his career, to unmask, he recalled in his Speeches to the Swedish People (Tal till Svenska Nationen) that 'It was an obscure language, which abandoned all content and sought to work solely through the resources of language, awakening perceptions of colour and sound, in short to conceal what should be seen, hide light under a bushel and operate with dark rays of light' [SV 68, 88]. But there is no doubt that in any account of the remarkable shifting his own work from the naturalism of the 1880 s to what, in Legends (1898), he termed the 'supranaturalism' of his postInferno writing, symbolism has a part to play as one element among many in the remarkable ferment of ideas to which he committed himself between his departure from Sweden for Berlin in September 1892 and the publication of Inferno in 1897 and To Damascus I-II in 1898. As is well known, during this period in which he negotiated a passage from the nineteenth-century structures of feeling of his principal naturalist works to the full-blown modernism of such later texts as A Dream Play (1901) or the stream-of-consciousness novella The Roofing Feast (Taklagsöl, 1906), Strindberg wrote almost no imaginative 
literature but abandoned himself to a variety of other discourses - scientific, alchemical, occult - in which it is notoriously difficult to discern a unifying pattern. And yet, to simplify: what eventually enabled him to resume his career as a dramatist, and in so doing to establish a basis for theatrical modernism, was the development of a new language that he forged during this period, much of it spent in Paris where he clearly played the field of the available journals and publishing houses, including the symbolist La Plume, with considerable promiscuity.

In what follows I wish briefly to note two of the major routes by way of which Strindberg effected this return to the theatre, and to consider them in the context of French symbolism. Although, soon after arriving in Paris, he briefly sought literary notoriety in the then fashionable detraqué style with the prose meditation 'Sensations détraquées' (Deranged Impressions, 1894), which Strindberg told the painter Richard Bergh was regarded by his drinking companions at the Café Napolitain as 'new, extraordinaire but mad' $[\mathrm{X}, 35 ; 2,519]$, and then rapidly went on to discover common ground with the symbolists in their mutual interest in alchemy (like Mallarmé, he was preoccupied with what the latter described, in a letter to Henri Cazalis, as 'L'CEuvre, le Grand Oeuvre, comme disaient les alchimistes, nos ancêtres'), ${ }^{2}$ he did not, it is true, seek to emulate the latter and 'describe not the object itself, but the effect it produces.' Indeed, his imagination was always too concrete for such an approach. But few more than Strindberg have been so haunted by what Mallarmé termed 'the demon of analogy', and his later achievement as a dramatist is inconceivable without the crucial shift in his attitude to the domain of language that he essayed during the mid-1890s, a shift that was achieved, in part at least, by his encounter with one of the principal inspirations of symbolism, Swedenborg, who, as Baudelaire famously commented, in his essay on Victor Hugo, 'has already taught us that everything, form, movement, number, colour, perfume, in the spiritual as in the natural, is significant, reciprocal, converse, correspondent... Thus, what is a poet (I take the word in its widest sense) if not a translator, a decipherer?' ${ }^{4}$

First, however, a brief comment on Strindberg's naturalism. In his early years, and still more intensively during the 1880s, Strindberg had frequently expressed misgivings about the pleasure to be derived from works of art, and in particular from imaginative literature, or fiction, which at the time he often regarded as essentially duplicitous, unlike his touchstone, nature, which for the moment at least he considered artless. His youthful Pietism, which was first compounded with a highly personal reading of Kierkegaard, for whom the ethical is elevated above the aesthetic, and subsequently augmented by a militant utilitarianism which caused him to argue, like one of his main mentors at that time, the Russian critic and novelist Nikolai Chernyshevsky, in favour 
of an art that was devoted to social or scientific ends, frequently led him to distrust the imagination, and to disparage its works as a form of irresponsible play. Thus, in the polemical tract 'On the General Discontent, its Causes and Cures' (Om det allmänna missnöjet, dess orsaker och botemedel) of 1884, which he described in a letter to his publisher, Karl Otto Bonnier, as 'the key to all my writings' [IV, 35], he 'disowns part of his previous work as [that of a] "player" and draws 'the sharpest distinction between the pleasurable and the useful' [SS 16, 43]. Where, in the past, 'the writer was originally a player out to "amuse", his role is now to speak plainly, and his (Strindberg's) own writing, in which he assumes the challenging role of a 'teller of truths' (sanningssägaren) - is predicated upon a moral imperative. Thus, he insists that he would like to write 'brightly and beautifully', but that he may - or can - not since it is his duty to tell the truth, and then goes on to overturn the traditional hierarchy of 'skald', 'författare' and 'litteratör' (poet, author and journalist) that prevails within the late nineteenth-century Swedish literary institution in order to praise the latter because, unlike the two former, who beautify and play to the gallery, 'he is the one who, when he is honest, says the straight [lit. pure - ren] word at the right moment, avoiding every loophole' [SS 16, pp. 43, 50]. In 'On the General Discontent' it is 'the plain word' (det blanka ordet) that he prizes, 'the naked word of the newspapers [which], on the assumption that it is true, is greater than the embellished language of the imaginative writer' [SS 16,53 ], while in the brief essay 'On Realism' (Om realism) of 1882, he accepts the accusation of being a naturalist as 'an honorary title', and declares that he and his school of writers 'love nature' and 'because we hate the artificial, the heightened, we love to call each thing by its name' [SS 17, 196].

To call a spade a spade, in short. Nothing could be further from symbolism, at least as it is formulated by Mallarmé, for whom evocation, allusion, and suggestion supplant description in order that the poet may, as he expresses it in Crise de vers, 'deliver up that volatile scattering which we call the Spirit and institute an exact relationship between the images, and let there stand out from it a third aspect, bright and easily absorbed, offered to divination' (liberer... la dispersion volatile soit l'esprit... Instituer une relation entre les images exacte, et que s'en détache un tiers aspect fusible et clair présenté à la divination). ${ }^{5}$ Any such suggestion is anathema to Strindberg during the 1880s, however, as a celebrated formulation from his essay 'On Realism' makes plain:

The author of these opinions can, when he reads an old-fashioned poem about a rose and a butterfly, not see these abstract family notions; his eye suffers agonies before it can select the species. This image can thus not elucidate the symbol either, the inner, spiritual, 'the inconstancy of love', for where the sensation is vague the idea becomes woolly. [SS 17, 192-93] 
There is a suggestion of what a less diffuse, more scientifically precise, literature might mean in practice in the short story 'Above the Clouds' (Över molnen), from the collection Utopias in Reality (Utopier i verkligheten), which Strindberg wrote in Switzerland two years later during the period when he was most immediately under the influence of the Russian nihilist movement. Two writers, Aristide and Henri, meet by chance on the verandah of a hotel from where they survey the beauty of the landscape; both of them are ill and on the verge of literary as well as mortal extinction. After Aristide has sought to 'say something beautiful about the Alps in the form of a poetic simile in which the clouds enveloping the mountain are compared to a host of angels, he concedes that while his formulation may 'tease the imagination [it] offers no clear picture', thus leaving the way open for his comparison to take the idea further:

Good! But how do you imagine the people of tomorrow will compose their poetry about the Alps? Like this perhaps: 'Dent du Midi; your secondary stratum of lime mixed With Dolomite; is today covered with snow; for three millimetres of snow fell in the night and the Bise blew with a storm force eight; when the snow melts we shall be able to sow maize; and break up the earth in our vineyards for the second time' [SV 19, 135]. ${ }^{6}$

In his own practice, of course, Strindberg did not adopt this parodic extreme. But for as long as he sought to live up to this conception of naturalism, the language that he employed, at least ostensibly, assumed a kind of transparency, even if, in the major naturalist plays of the later 1880s, this proved to be a very much more complex issue than these urgently polemical statements suggest. It observation was one of the key words of the age, and the ideal author a combination of newspaper reporter (referent) and scientific vivisector, the paradigm of the modern writer was not, as has sometimes been claimed, the photographer, whose transparencies purported to reproduce the world exactly as it appeared to the observing eye, but, even now, a beholder who was sensitive to the elaborate patterning that might be discerned in the far broader canvas of what Strindberg defined, in his 1889 essay 'On Modern Drama and Modern Theatre', as 'the greater naturalism' [SS 17, 289].7 As Roland Barthes declares, in Camera Lucida, of the essentially deictic language of photography, in a photograph 'a pipe... is always and intractably a pipe'; but in even the most realistic theatre, physical Objects as part of the mise en scène (Hedda Gabler's pistols, for example, the Count's boots in Miss Julie, or the pipe that Osvald smokes in Ibsen's Ghosts) tend to assume an active role and conjure up, or evoke, what is not immediately tangible and visible in the physical reality of the scene. Framed and focused, such objects already share in what Clive Scott has called 'Baudelaire's surnaturalisme, a state of perception which intensifies the existence of things, makes them hyperbolically themselves.' 
Nevertheless, writing naturalistically ultimately poses irresolvable problems for Strindberg. Given the nakedness with which he displays both himself and those most intimately related to him as items in the literary market place, an acute moral dilemma is apparent in his conception of naturalism from the outset. As he remarks, in the celebrated foreword to his autobiographical fiction, The Son of a Servant (1886), 'One only knows one life, one's own' [SV $20,373]$, and this must therefore form the basis of any literature that makes a pretence of truth. But there is then a consequence. If he is not to be quite literally written out, and start repeating himself, with all the consequences which that will have for a readership continually in search of something new, the writer must accumulate the capital of fresh experience, which has then immediately to be reinvested in language. As the literary entrepreneur, Smartman, observes in Strindberg's savage late fictional analysis of the literary scene, and his own role in it, Black Banners (Svarta fanor, 1904): 'Better an unhappy marriage, however, than none at all. One goes through it and comes out with more experience than before, and experience is capital' [SS 41, 290]. But the kind of conspicuous consumption of private experience in which Strindberg engages in his writing is ultimately a form of self-consumption (the vampire finally feeds upon itself, as the late chamber play The Pelican (1907) suggests), and such 'collections of experienced material' (materialsamlingar av erfarenheter), as he calls them in The Son of a Servant [SV 20, 209], are accumulated not only at a cost to himself but with painful consequences for others. After all, as Smartman implies, one does not live alone, and the impulse behind the seemingly directionless period between 1892 and 1897, during which Strindberg wrote little or no imaginative literature, is not only to renew himself as a writer, but also, and fundamentally, a reaction against the mode of writing in which he has so recently indulged, not least the literary execution of his first wife in the autobiographical fiction A Madman's Defence (1887-88), a book which the poverty of his rapidly disintegrating second marriage to Frida Uhl now tempts him to publish during this apparently fallow literary period in his life. Torn between the naturalist code of speaking what he regards as the naked, if painful, truth and the deeply felt immorality of making public his own and other people's private lives, he now experiences how 'the increased distaste which he had for some time felt for his profession as a writer developed into an abhorrence':

What an occupation (he writes, in 1898, in the autobiographical fiction The Cloister (Klostret)): to sit and flay one's fellow human beings and then offer their skins for sale and expect they should buy them, to be like the hunter who in his hunger hacks off his dog's tail, eats the flesh himself and gives the dog the bones, his own bones. To go about spying out people's secrets, to betray one's best friend's birthmark, use one's wife 
as a guinea pig, behave like a Croat, chop down, defile, burn and sell. Ugh! [SV 50, 95]

And when, after a six years' silence, Strindberg does eventually return to the theatre with a play (To Damascus I) that, however autobiographical, is manifestly the product of a new aesthetic, one fashioned, at least to some extent, in the environs of French symbolism, it is also worth noting that the writer's block, or 'creative bankruptcy', from which its protagonist, The Stranger (or The Unknown - Den Okände), describes himself as suffering, is due at least in part to the revulsion that he feels for his most recently published book, which turns out, of course, to be an account of his previous marriage. In short, it is only when Strindberg has evolved a new manner of writing that he is able to acknowledge a link between his guilt and his literary impotence, and thus once again enjoy what, in one of his letters to Axel Herrlin, he rather coyly calls 'the grace of being able to write for the theatre' [XII, 273; 2, 623].

Two activities stand out as playing a central role in the process of growth and artistic renewal that Strindberg underwent in the years between 1892 and 1897: his commitment to science and his painting. Indeed, the two provide an intriguing complement to each other, with the residue that accrued in his crucible sometimes resembling the form and colour of the scrapings that accumulated upon his palette. Likewise, in both practices, he enjoyed a freedom from the kind of moral dilemma that his naturalist aesthetic had imposed upon his writing. The chemical nomenclature and mathematical symbols on which he now relied to describe the natural world offered him a neutral language, one that encumbered him with no personal moral dilemmas, even though in time the formulae of such so-called 'chemical sonnets' as 'Types and Prototypes in Mineral Chemistry' (Typer och prototyper inom mineralkemien, 1898) or the Pythagorian speculations of 'Les Nombres cosmiques' (1898), would enable him to discern 'the master builder, conscious, calculating, measuring, writing his record of creation sometimes the right side up, easy to read, sometimes concealing his intentions in a back to front, or disguised, code' [SS 27, 560] in what appeared to him to be the remarkable consonance and order of, for example, the analogy between the atomic weight of metals and the distance of the planets from the sun or the composition of water and the distance of the sun from the earth [SS 27, 434-37]. Likewise, in his painting, where he was prepared to sanction the notions of play and pleasure that he found unacceptable in his writing, the aleatory practice that he describes in the essay 'The New Arts! Or the Role of Chance in Artistic Creation' (1894) gave Strindberg the freedom to explore his relationship to the natural world in a similarly open-ended way. In his painting he no longer seeks to create works of art that imitate, or transcribe, nature but rather to emulate what he understands to be nature's own artistic method and fashion 
new works in the way that he now assumes nature creates, with prodigal turns of fancy that have little to do with the rapidly emerging scientific orthodoxy of Darwinism. Moreover, if nature thus comprises a series of works of art, then again this supposes a creator whose handiwork, as Strindberg studies it in Paris in the miniature universe of the Jardin des Plantes, is to be discerned in what he calls nature's own visible pictures, those images or artefacts in the natural world that bear a striking resemblance to his own artistic caprices. Beginning with what he believed might be the random play of chance, by 1896 both his mathematical and chemical speculations and his painting have revealed a coherent design within the apparent chaos of the natural world, and hence, as part of that world, his own life too must have a presumably sensible and therefore moral meaning.

In short, the natural world that he portrays in his painting and in his scientific pamphlets emerges as a modernist work of art, to the external eye an apparent chaos but one in which the internal eye of the freely associating painter or speculator can discern a world of similarities, coincidence, and repetition. The universe now appears to Strindberg as a vast sign system whose creator has impressed his signature upon everything, from the markings on the throat of a moth to the tracings upon the surface of meteors and the shells of crabs, and from the atomic weight of metals and orbits of the planets to the circumstantial detail of his own life, which he was now once again prepared to try and recover in literature, beginning with the autobiographical fiction Inferno.

It is in seeking to define the language of this polysemic world, which he variously calls a 'cabbalistic cryptogram', a 'cipher', or a system of hieroglyphics, and where the visible seems always to bear a hidden relationship to an invisible world of correspondences or symbols, that an affinity between Strindberg and the French symbolists is most apparent. It is now that the streets of Paris and the landscape around Klam, near Grein in Austria, that he depicts in Inferno confirm Baudelaire's previously cited remark from L'Art romantique, namely that 'tout, forme, mouvement, nombre, couleur, parfum, dans le spirituel comme dans le naturel [est] significatif, réciproque, converse, correspondant'. ${ }^{10}$ Baudelaire's account of Paris as a forest of symbols in which forms are dissociated from their normal meanings and become threatening and strange anticipates the urban landscape that Strindberg explores in his novel, as it does the later surrealist fictions of André Breton or Louis Aragon. Likewise, his account of metaphor in the hands of 'les excellents poètes' as 'une adaptation mathématiquement exacte dans la circonstance actuelle, parce que ces comparaisons, ces métaphores et ces épithètes sont puisés dans l'inépuisable fonds de l'universelle analogie' ${ }^{11}$ is clearly in keeping with the link that Strindberg infers between science and the poetic imagination at this time, when the metaphorical thought processes that he had previously 
condemned as irresponsible play are now advanced as the basis of a scientific as well as a poetic method. The demon of analogy or, as Strindberg writes in his essay on the sunflower, 'Solrosen' (1896), the inclination 'to "see similarities everywhere"' (att "se likheter överallt" [SS 27, 358]), was now the basis on which the multiplicity and seeming disorder of the world that had eluded definition, even in the desperately seeking naturalism of By the Open Sea (I havsbandet, 1892), could be explained, and he sought urgently in the past for authorities, including variously Francis Bacon, Elias Fries, Bernardin de SaintPierre, Linnaeus, and, finally, Swedenborg, who might reinforce his method and confirm the existence of 'the infinite coherence in the apparently great disorder' (det oändliga sammanhanget i den skenbara stora oredan! [SS 27, 560]). 'Analogier $=$ korrespondenser $=$ harmonier', as he asserts at the start of 'Solrosen', thus equating Mallarmé and the symbolists with Swedenborg (correspondences) and Bernardin de Saint-Pierre (harmonies), in his search for a language that could sustain a literature in which the concrete vigour of his earlier naturalism might be underwritten, or validated, by the ability of this language to suggest, even as it minutely describes the visible world, the existence of another dimension, an unseen reality that would permit him to write as fiercely and revealingly of himself and his contemporaries in, for example The Pelican or The Dance of Death (1900) as ever he had done in the past, in A Madman's Defence or The Father (1887). Indeed, in this respect he goes beyond Mallarmé, who had conceded, in Crise de vers, that 'the diversity of idioms on earth prevents anyone from uttering the words which otherwise would be, by a single impression, materially the truth itself (la diversité, sur terre, des idiomes empêche personne de proférer les mots qui, sinon se trouveraient, par une frappe unique, elle-même matériellement la vérité). ${ }^{12}$ For Strindberg, as for Talleyrand, whom he frequently quotes or paraphrases, the Babel-like confusion of this diversity generally suggested that 'La Parole a été donné à l'homme pour deguiser sa pensée' (man has been given language in order to conceal his thoughts), ${ }^{13}$ and he frequently argued that it was thus employed to sustain the individual in his illusions and society in maintaining the public lie, with one notable exception, namely his own words as he confides them to the silence of the white page on which he writes. Here even after the revaluation of all his values during the mid 1890s, Strindberg still felt it a calling and a duty to intervene with the author's time-honoured freedom in human lives and destinies ('I sometimes wish I had been a writer with the well-established right to engage in every facet of people's lives and fates, a calling and a duty', as he has one of his narrators express it, in 'The Quarantine Master's First Tale' (Karantänmästarns första berättelse [SV 50, 191]). But what now gave him this authority was, he believed, that relationship with the beyond, or Jenseits as he sometimes called it, into which he entered through his awareness of the 
symbolic dimension of language, a text which he was learning to decipher even in its most mundane manifestations.

Unlike Mallarmé, therefore, his ideal is not merely to suggest but still to name, or rather, as in (say) The Dance of Death, with its roots in his relationship with his sister, Anna, and her husband, Hugo von Philp, to do both at once. ${ }^{14}$ It is consequently here that the interest in Swedenborg that he shares with the symbolists also serves to distinguish Strindberg's practice from theirs. Swedenborg's correspondences may offer intimations of another world, but first and foremost they manifest themselves as real experiences in this one. What appealed so powerfully to Strindberg in Swedenborg, besides the notion of vastation that provided him, as Göran Stockenström has shown, with a kind of dramatic peripeteia around which to structure his later plays, ${ }^{15}$ was the circumstantial realistic detail of his visions, in which Strindberg recognized not only his own dreams but also his very own local habitation and name. As Gunnar Brandell observed, in Strindberg in Inferno, 'Nothing separates Strindberg from the symbolists so decisively as his stronger dependence on concrete reality and actual experience. The symbolists either created their symbols by an act of the imagination or else appropriated them from the fairy-tale world of romanticism. Strindberg found most of his symbols in exactly observed reality... A symbol is always something concrete that entails something abstract, but whereas the symbolists emphasize the abstract element, Strindberg stresses the concrete.'. ${ }^{16}$

Thus he never entirely abandons naturalism. The concrete data that he collects from 1896 to 1908 in The Occult Diary, which is both a repository of objets trouvés and an ongoing dictionary of symbols that is first explored in Inferno and subsequently deployed in To Damascus and the later plays and novels, remains the 'infinitely small detail' that, according to the Danish critic Georg Brandes, the realist or naturalist writer should use to 'reinforce the illusion of reality', although as Brandell, again, suggests, such detail now 'opens a window onto something beyond the real'. ${ }^{17}$ Or, as Strindberg himself was to remark, in Black Banners: 'Everyday life is full of mysticism, but you see so badly; and you must be a Naturalist in order to become a mystic. But it is not only a question of being able to spell, you have to "join it up", otherwise you can't read' [SS 41, 200].

Strindberg was himself a masterly reader of this kind, and nowhere more obviously than in the following brief passage from Inferno. Walking down a street in Meudon, where he has gone 'utan bestämd avsikt' (without any particular purpose) on a day trip from Paris, he catches sight of the statue of

... a Roman knight wearing iron grey armour, half buried in the ground... The knight is regarding the adjacent wall and guided by his gaze I am able to see an inscription in charcoal on its white-washed surface. The 
intertwined letters $\mathrm{F}$ and $\mathrm{S}$ lead me to think of the initials of my wife's name [Frida Strindberg]. She loves me still! A second later the thought of the chemical symbols for iron and sulphur $F e$ and $S$ suddenly flashes upon me and before my very eyes the secret of gold is revealed. [SV 37, 69]

But at this point one realizes that in exploring the concrete detail of everyday life in which the mundane residue of his private experience coheres with the detritus of the urban landscape, It is neither Mallarmé nor Swedenborg with whom the rapid play of Strindberg's symbolically associating imagination has most in common, but his near contemporary Freud, who, like him, was even then seeking to decipher the syntax and symbolism of the unconscious. That Strindberg had recourse to Swedenborg and an earlier form of dream interpretation in seeking to interpret these 'analogies = correspondences = harmonies' is understandable; for although he shared many points of reference with Freud (for example Die Philosophie der Mystik (1885) by Carl du Prel, whom Freud, in the 1914 edition of The Interpretation of Dreams, called that brilliant mystic' and 'one of the few authors for whose neglect in earlier editions of this book I should wish to express my regret'), he did not know Freud's work and, for all the sophistication of his own associational processes, he was not prepared to make the kind of symbolical interpretation that these multivalent texts continually invite. Thus here, for example, that the letters $F$ and $S$ should reveal the secret of a substance for which he had long been seeking, and which in chemical nomenclature shares the initial letters of his own authorial first name, $\mathrm{Au}$, is a correspondence that even Strindberg appears not to have noticed. Perhaps that was just as well! ${ }^{19}$ 


\section{0. 'New Arts, New Worlds!': Strindberg and Painting}

Writing to his fiancée, Felice Bauer, in 1916, Kafka turned aside from his own concerns to commiserate sincerely with her: 'It really does seem too much that you should attend a regular course of lectures as well,' he wrote. 'And lectures on Strindberg at that! We are his contemporaries and his successors. One has only to close one's eyes and one's own blood delivers lectures on Strindberg.'

Kafka was writing just as the great wave of productions of Strindberg's dramas that swept through Germany in the years shortly after his death in April 1912 was about to break - in 1912-13, for example, there had been 281 performances of his plays there; in 1915-16 there were 789, and in 1922-23 there would be $1,024 .^{2}$ Kafka was therefore not alone in having Strindberg in his blood; he was a contemporary enthusiasm shared by (among others) Schoenberg and Karl Kraus, for whom Strindberg meant not only the plays but also novels like Gothic Rooms and Black Banners or the autobiographical fictions Inferno and Jacob Wrestles, which Schoenberg seriously considered making the subject of an opera.

Strindberg's international reputation rests, of course, on his plays, but this central European response to his work only confirms how, in this country, our knowledge even of the plays remains for the most part slender and partial. Of his dramatic works in several genres, only a handful - some four or five - are performed here with any regularity - Miss Julie, The Father, Creditors, The Dance of Death; the sequence of twelve plays on subjects from Swedish history, which includes a number of his finest works as a dramatist, is largely unknown while several of the major plays with which he helped to establish the basis of theatrical modernism - To Damascus, A Dream Play, The Ghost Sonata, or The Pelican have rarely occupied the British stage. Whereas Strindberg impacted powerfully upon the work of (for example) Artaud and Max Reinhardt or O'Neill and Giorgio Strehler, he has had little direct influence here, either upon English dramatists or directors.

Not surprisingly, therefore, his achievements in other areas have gone unrecognized, although as an historian he wrote, in two volumes, the first still readable history of Sweden from the point of view of its people rather than its 
kings, and he originally made his reputation not as a dramatist but as a novelist, with The Red Room, an iridescent narrative of contemporary Stockholm life that is by turns comic, pathetic and satiric, and in which the influence of Dickens and Balzac is adroitly balanced. Like its successor, The People of Hemsö, it is, moreover, a book that belies the common reproach that Strindberg's work is entirely self-obsessed and lacking both imagination and humour, as indeed do many of his short stories on both historical and contemporary themes. The sequence of autobiographical fictions, meanwhile, beginning in 1886 with the naturalist dissection of his early years in the four volume The Son of a Servant, and concluding in 1903 with an evocative portrayal of old age and the artistic process in Alone, forms the backbone of his life's work, and an informed response to any one aspect of this multifaceted project ultimately benefits from a knowledge of its other manifestations, which include several volumes of poetry, works of satire and political polemic, studies in natural history, and essays in sociology, psychology, history, alchemy, natural science and linguistics. He was also a significant photographer and painter.

It is partly this sheer variety which discourages familiarity. Even as a playwright Strindberg shows none of the consistency, in form as well as in focus, that characterizes the work of his close contemporaries lbsen or Chekhov. Whereas Ibsen may develop and refine the uses to which he puts the dramatic form that he adopts for the scenic portrayal of contemporary life, there is common generic ground between all the plays in the sequence from The Pillars of Society to When We Dead Awaken; Strindberg, on the other hand, confronts us with what appears to be a radical discontinuity between the naturalistic works of the late 1880s and the modernist dramaturgy of his later plays, beginning in 1898 with the first part of his trilogy To Damascus. Indeed, what renders Strindberg's achievement as a dramatist so striking is that having brought one form (the extended naturalist one-acter) to maturity in Miss Julie and Creditors, he then abandons its comparative security in order painfully to effect the modernization of what remains his primary medium during the late 1890 s and early 1900s. Of his near contemporaries in any art, perhaps only Yeats achieves something similar, although on nothing like the same scale.

Ultimately all of Strindberg's work forms part of a single project, but it is appropriate for once to concentrate upon one of its less well-known aspects, his painting. This also happens to have been central to the way in which he negotiated the transition from nineteenth-century structures of feeling in the dramas of the 1880s to an achieved form of theatrical modernism in A Dream Play and The Ghost Sonata.

Strindberg is frequently seen as unusual among writers who paint in that unlike the majority of such authors, he expresses himself in painting not only though his choice of subject matter but also, and perhaps more significantly, 
through the materials he uses, of the colours as colour, or the use to which he puts the structure of the paint itself on whatever surface he happens to be working. His pictures, that is, are painterly rather than literary, and rely on the inherent expressiveness of the medium in which he is working rather than on any anecdotal dimension. There is certainly some truth in this: in what are perhaps his most achieved paintings, those he produced during the mid-1890s, such as High Seas [Hög sjö, Paris, 1894] or The Verdant Isle [Den grönskande ö, Dornach 1894], Strindberg comes close to abandoning virtually every trace of descriptive representation; in these works where, it has been argued, there is sometimes a striking anticipation of abstract expressionism, it is the medium rather than the subject that preoccupies the viewer. Nevertheless, it is equally true that throughout his career as a painter, he concentrates on a limited number of recurring and evidently very personal motifs, many of which, though painted much later on in his life, derive from early impressions - the seascapes and seamarks, towers or trees and wreath-framed grottoes of the Stockholm archipelago - which are as eloquent about the nature of his individual vision as any of his writings. As he wrote of his painting in the autobiographical fiction The Son of a Servant, 'One should paint one's inner feelings and not keep copying sticks and stones that in themselves are insignificant and could only assume any real substance by passing through the furnace of the perceiving and feeling subject' [SV 21, 10], an outlook that would ally him with the inward turn away from what was rapidly regarded as the superficiality of realism by, for example, both Van Gogh and Edvard Munch, who remarked: 'nature is not only what is visible to the eye - it also shows the inner images of the soul - the images on the back side of the eye,' and in such paintings as Heathland [Svedjeland, Dalarö, 1892] or Seascape with Cliff [Marin med klippa, ParisPassy, 1894], the subjects are very much a pretext for the emotion felt at the time of their creation.

Nevertheless, Strindberg was certainly unusually sensitive to the particular demands of painting as an art with its own distinct rules, a sensitivity that was fostered at least in part by his early experiences as an art critic. During the 1870s he wrote frequently and with increasing insight about painting in the Swedish press, progressing rapidly from narrative accounts of a painting's subject matter, like his 1872 essay on two historical canvases by Mårten Winge and George von Rosen, to an appreciation of the painterly qualities of a canvas, as in his comments on one of the foremost nineteenth-century Swedish watercolourists, Egron Lundgren. Lundgren, Strindberg wrote, in a review in Dagens Nyheter in May 1876, 'was a painter - a colourist - and all the things in life he took up were presented in the magic light that he was able to produce with such material means as water and paint dyes' [SV 4, 211]. According to Sixten Strömblom, whose two-volume Konstnärsförbundets historia ${ }^{3}$ remains 
the standard history of Swedish painting during this period, Strindberg was the only nonprofessional Swedish writer on painting of his generation with the ability to be an art critic in the modern sense of the word. In 1876, for example, he was among the first to introduce the Impressionists to Sweden, in a series of articles in the leading Swedish daily newspaper, Dagens Nyheter, even if he did indulge in some characteristically irreverent comments about the pictorial galenskap, or insanity, of these painters in the process [SS 4, 145-57]. Although his own painting owes little to the Impressionists, he could see that they painted nature as it appeared to the eye, in movement, thus anticipating the paintings of his own maturity, like The Danube in Flood [Översvämning vid Dornau, Dornach 1894] or the elemental Snowstorm at Sea [Snöstorm vid havet, Paris 1894], which were painted according to what he called the 'teleology of chance': one 'work[s] like nature, not from nature,' he would maintain [XI, 215], and thus depicts a world in constant motion: 'The old school,' he wrote, 'sought to create an illusion of reality by faithfully rendering nature in every detail - the new painters sought the overall impression and to present nature not as it was but as it appeared to the poetically observing eye. It was... the impression, not the meaningless object itself that they sought to reproduce' [SS 4, 139].

Hence, as he wrote, in another of his early reviews, 'If we start from the simple truth that a painter is a painter, then the assessment of a painting is bound to hang in large measure on how it is painted', ${ }^{4}$ and his mature art criticism is distinguished by a willingness to concentrate on the qualities of the painting as such. 'Artists,' he observed, 'never talk with one another about a painting except in terms of how "it is made", and for them the value of a work of art resides only in whether or not "it is well made"; as for the subject matter, or anything elevated, that does not concern the painter'.

Strindberg's insights were undoubtedly fostered by his close acquaintance with a series of painters, beginning, in 1870, with Per Ekström, on whom he based the character of Sellén in his novel The Red Room. Subsequently, he enjoyed lasting friendships with a number of important Swedish artists, including Richard Bergh, Karl Nordström, and Per Hasselberg, in whose company he enjoyed a freedom from the rivalry that sometimes accompanied his relationships with other writers. But his principal source of knowledge was, of course, his own painting. This falls into three main periods, of which the second emerges in retrospect as the most significant, and in order to clarify his overall achievement as a painter, it is useful to review its development here.

Beginning in 1871, when he spent the first of several summers on the island of Kymmendö in the Stockholm skärgaird - the archipelago which remained for him the touchstone of natural beauty throughout his life - he produced a number of works in the early years of the decade. These are mainly 
unpretentious drawings and studies from nature, but they culminate, in 1874, in Seascape by Moonlight [Marin i månsken, Stockholm 1874], the first of his paintings to which he appended his signature on the front, in which the free and full modelling of the waves, the nonchalant asymmetry of the pale moon, and the blue-green light of the sky echoed in the dark green water has encouraged comparison with later developments in painting rather than with any contemporary models. Perhaps with the seascapes of Emil Nolde in mind, the art critic Göran Söderström has pointed out that, 'Instead of the striving for contemporary naturalism we have [here] a painting pure and simple, an artifact that subordinates form to colour and expression. This is a highly independent work, an expressionist forerunner in Swedish art.'

Although Strindberg retained close contacts with a number of artists during the 1880s, including the important colony of Scandinavian painters that had been established at Grez-sur-Loing, near Paris, he appears not to have painted again until the early 1890s. Then, in the wake of the collapse of his first marriage, and with the Swedish theatre manifesting scant interest in staging his recent naturalistic dramas (Miss Julie, for example, which was written in 1888 had to wait until 1906 for its first professional production in Sweden), he returned to painting and also sculpted, while staying among artist friends at the resort of Dalarö, south of Stockholm. Originally, he used whatever came to hand - book covers, cardboard, the zinc plates of an accumulator - a practice that was in keeping with his spontaneous and direct way of working in, for example, a curious prefiguration of Magritte, the so-called Double Picture [Dubbelbild, Dalarö 1892] in which one image appears to have been superimposed upon another to create a dual impression of framing and immediacy. Whatever the case, however, these hard surfaces responded better than canvas to the technique he now adopted of applying the paint with a palette knife, or even his fingers, rather than a brush, and there are in fact only two known paintings on canvas from 1892. Strindberg would later praise Rubens because his pictures appeared to be 'built' with a knife rather than 'stroked' with a brush [XVIII, 81], ${ }^{6}$ and here, for the first time, he allowed the material and the colours to determine the form of each painting, and relinquished all pretence of naturalism. Although each painting retains a recognizable motif, the powerful emotional charge of these works derives as much from the way in which they are built up according to the formal properties of the pigments themselves as from their subject matter.

When Strindberg left Sweden in 1892 for his second extended sojourn on the continent (he had previously lived in France, Switzerland, Germany and Denmark between 1883 and 1889), he continued to paint. In Berlin, for example, he sent the painting Night of Jealousy [Svartsjukans natt, Berlin 1893] to Frida Uhl, the young Austrian journalist who was shortly to become 
his second wife, with the dedication, 'from the (symbolist) painter August Strindberg. The Painting [he wrote on the back of the canvas] represents The Sea (below on the right), Clouds (above), a Cliff (left), a Juniper Bush (top left, and symbolizes: A Night of Jealousy.' This is the first time that Strindberg provides an explicit symbolic interpretation of one of his paintings, although in fact the actual painting lacks any evident symbol: it is, rather, a characteristic internal landscape of the soul, an expression of powerful, barely contained emotion, and it was only subsequently that he identified its esoteric significance with this inscription.

The same applies to the paintings he produced in Austria in 1894, to which - in a frequently quoted letter - he attributes two levels of significance, one exoteric and the other esoteric. 'It is in fact a new (that's to say, old kind!) of art which I've invented and call L'art fortuite', he told Littmansson:

I've written an essay on my method. It is the most subjective of all art forms, so that in the first place only the painter himself can enjoy (= suffer) the work because he knows what he meant by it, as do the chosen few who know the painter's inner (= outer) a little (=a lot). Each picture is, so to speak, double-bottomed, with an exoteric aspect that everyone can make out, with a little effort, and an esoteric one for the painter and the chosen few. It should be pointed out that the pictures were painted in a half-dark room, and cannot on any account stand a full light; they appear best in strong fire-light or a half-dark room.

All the pictures are painted using only a knife and unmixed colours, whose combination has been half left to chance, like the motif as a whole. $[\mathrm{X}, 177 ; 2,494]^{7}$

Created directly on the canvas from a combination of the materials used and the painter's subjective and spontaneously expressed impulses, these paintings display a remarkable independence of prevailing artistic norms and in several instances carry Strindberg to the verge of an art, with no specific representational content. Although, as in Wonderland [Underlandet] painted in Dornach in 1894, or the later so-called Yellow Picture [Den gula hösttavlan] which dates from a later phase of activity in Stockholm 1901 he may adopt a familiar compositional motif from the Barbizon school in which a central area is framed by a wreath of foliage, such motifs are now barely recognizable. Indeed, only in the painting he subsequently entitled Golgotha [Golgata, Dornach 1894], is there a readily identifiable representational element, to be discerned in the three masts of a sinking ship on the right of the canvas, some two-thirds down - an image, incidentally, that is later deployed in both To Damascus and $A$ Dream Play. At the time the canvas was painted, however, he was more interested in the dark cloud formations in the almost uniformly coloured canvas, where one can clearly discern for the first time the influence of Turner, 
an artist with whom he could have become familiar at first hand during his abortive honeymoon with Frida Uhl in London, in 1893. So unconcerned was Strindberg by the naturalistic aspects of this painting that the three masts were in fact added to the composition to provide a kind of focus for the accidently achieved figure of a man in a billowing cape, standing on the cliffs to the left, looking out to sea, which he only noticed after he had, as he previously thought, finished the picture. As in all the paintings of this period, the esoteric meaning is no more intentional than the exoteric: what he actually does is retrospectively to allow his conscious mind to devise a meaning for what his unconscious has already created. The spectator Strindberg contemplates what the artist Strindberg has wrought. The meaning reveals itself only in the act of contemplating the picture, not in the act of painting it.

It was during this period that Strindberg came closest to working as a professional painter. He was certainly no Sunday dilettante and a times he even sought to live off his painting. He exhibited in Stockholm in 1892, in Berlin in 1893, when two of his canvases were hung with several by Munch in the Salon des refusés, after they had been rejected by the conservative Berliner Kunstverein, and in Gothenburg in 1895. And when, in 1894, he set his sights on conquering Paris, he arrived with a collection of his paintings, which were designed to make his reputation and help finance his stay. Once there, too, he accepted commissions from the art dealer, Willy Grétor, who provided him with paints and a studio in Passy: 'Am now a painter in Paris,' he told Birger Mörner proudly, in 1894, '[I]'ve sold for 400 Francs, though not to Swedes. Am being encouraged to exhibit at Champs de Mars. I am painting small decorative panneaux on cardboard. Have 10 ready. Do you think it's worth sending [them] to Örebro or Lund; (or Malmö) and will you help? They cost 35 kronor apiece with gold edged frame... Easily understood motives and sympathetic colours' [X, 265].

Although he sometimes writes slightingly of his work, and soon recoiled in trepidation from Grétor, whom he discovered to be a confidence trickster and art forger with, or so Strindberg suspected, designs upon his life, it was at this time that Strindberg produced a number of his best paintings, including the fine Beach Scene [Strandbild, Passy 1984] and Seascape [Marin, Passy 1894], and the outstanding Snowstorm at Sea and High Seas mentioned above, before he once again abandoned painting for several years. In this latter work, he has jettisoned the repertoire of naturalism: the picture is done with dry paint, possibly mixed with plaster of Paris to produce a high relief, and the only colours are dark grey and a browning white. A burner or paraffin lamp has been used to impart the warm effect of black soot and the whole is built up around a spiral movement such as Turner frequently used to create a sense of movement, that 'turbulence and wrath' which Ruskin identified in many of 
the latter's canvases, including the now lost Off the Nore: Wind and Water. As in Turner, this technique gives the composition a unique tension, affording the canvas 'a centre of turbulence' a source or centre of movement from which the picture seems to take its energy. ${ }^{8}$ In such paintings as Danube in Flood, this centre may be identified with the isolated clump of trees reflected in the water that surrounds them, and one may relate the use of such a seemingly insignificant 'storm centre' with Turner's practice in (say) Snow Storm, Steam Boat off a Harbour's Mouth of 1842, a canvas of which he remarked that 'I did not paint it in order to be understood', and where he exploits a patch of bluegrey sky seen through the storm, just above the ship, as the focal point of calm around which the clashing elements of the whirlwind revolve.

Why did Strindberg paint? The simple answer, one that he gives himself, is that he turned to painting in those periods when he found writing impossible. In the early 1890 s, for example, he was both disgusted by what seemed to him the personal implications of naturalism, which entailed depicting in revealing detail not only the writer's own private life but also the lives of those closest to him, and written out since he had temporarily exhausted the experiential capital which, he believed, it was the writer's duty to utilize in his works. Similarly, in his third, and final, period as a painter, during the first years of this century, a downturn in the interest shown by the Swedish theatre in his recent plays coincided with a crisis in his third marriage to the Norwegian actress Harriet Bosse. Quite clearly, therefore, painting provided him with a crucial means of self-expression when writing failed him. As he observes in The Son of a Servant, of his first attempts at painting: 'He got himself going by painting; from a need to see his hazy feelings take form, perhaps also to find a concrete way of expressing them, for the small, crabbed letters lay dead on the paper and were incapable of revealing as openly what he felt. He had no thought of becoming a painter, showing in an exhibition, selling paintings or the like. But going to the easel was like sitting down to sing' [SV 21, 9-10].

However, it is not simply that Strindberg turned to painting for relief in periods when, for one reason or another, he found writing problematic; the real significance of painting in his career is that it afforded him the freedom to experiment without the immediate risk of failure to which such experiment might have led had he continued writing. According to The Son of a Servant, even his earliest experience as a painter benefited his writing. Describing his autobiographical persona, Johan, he recalls how:

[One] November a shipwreck occurred under particularly picturesque circumstances, and Johan was present at the inquiry and its attendant feasting. The whole setting was so new and picturesque that he felt an urge to depict it, but brushes and paints no longer sufficed; he had to turn to his pen, and so he wrote several articles for Stockholm's liberal morning paper. 
Painting had somehow sharpened his vision, enabling him to perceive details acutely and, by accumulating and arranging them, to evoke in the reader a vivid picture of the event. [SV 21, 82]

Strindberg's visual imagination, pictorial sense, and eye for detail, so evident in an early work like The Red Room, were not dependent upon his painting, although the latter may have refined them further. There is however, no doubt that painting played a central role in the process of growth and artistic renewal that he underwent in the six years between 1892 and 1898, a period during which he wrote no plays and almost no other works of fiction. As Harry Carlson has pointed out, 'in the later 1890s a new faith in the power of the visual imagination, together with a changed attitude toward nature - thinking it, seeing it, and feeling it as form - were vital mediators in the renewal of his art' in general, ${ }^{9}$ and it was in large measure via his paintings, and the essay, 'The New Arts! Or the Role of Chance in Artistic Creation', in which he glossed the aesthetic that lay behind them, that the renewal of his art as a dramatist was effected. ${ }^{10}$ As in the scientific and alchemical experiments of these same years, where the substances that appeared under his microscope or in his crucible sometimes resembled the form and colour of his paintings, and were endowed by Strindberg with a similar ability to transform themselves into each other according to what he identified as the capricious laws of nature, he was seeking a vision of the world that would serve as a new basis for his writing. Indeed, there are numerous affinities between his painting and (for example) his experimental photography, like the celestographs that he produced during 1894, working without a camera and exposing photographic plates that had already been immersed in developing fluid directly to the night sky in order to obtain as direct an Image as possible, uncontaminated as he saw it by the subjectivity of the human eye or the shape of a camera lens. ${ }^{11}$ His paintings, these photographs and the gold that he was convinced he had produced both by the wet and the dry processes of an idiosyncratic chemistry were not the aimless residue of accident but an essential part of the personal revaluation of all values in which he was engaged at the time. In short, Strindberg's palette, like his crucible, was one of the vessels where he forged a new world, and the residue that accrued in the bottom of the one sometimes resembled the scrapings that remained upon the other.

Strindberg had in fact always been attracted to science. In his early years, and still more intensely during the 1880s, he had often expressed misgivings about the pleasure to be gained from works of art, and in particular imaginative literature, which he considered essentially duplicitous, unlike his touchstone, nature, which at that time he considered artless. His youthful Pietism, compounded by a very personal reading of Kierkegaard, for whom 
the ethical is elevated above the aesthetic, and further strengthened by a militant utilitarianism which argued in favour of an art that was devoted to social or scientific ends, had frequently led him to distrust the imagination and disparage its works as irresponsible play. 'Literature,' he argued, in 1886, 'should emancipate itself from art entirely, and become a science... writers [should] learn their craft by studying psychology, sociology, physiology, history and politics. Otherwise we'll become mere dilettantes' [V, 339; 1, 202]. The long-standing conflict between these views and his own creativity was one of the many reasons for Strindberg's prolonged silence as an imaginative writer in the mid-1890s, and it also accounts, at least in part, for the urgency of his commitment during these years to both scientific speculation and painting.

For where painting was concerned Strindberg was sometimes prepared to sanction the notions of play and pleasure, and to waive the kind of photographic realism that he initially expected of the writer, but seldom reproduced himself. 'Those of you who first and foremost desire a photographic fidelity to nature,' he wrote, in one of his early reviews, where he addressed the limitations of a documentary realism in painting, 'take a look at [this painting by] Cantzler. It makes no difference whether you look at it through an opera glass or go in close. Does it achieve the illusion of reality in every detail? At first, yes, but with that everything is said and done; a pine looks like this, a flower like that, a tree-stump thus, and there's nothing else to say; it becomes as boring as a completed puzzle, and one listens in vain for the invisible music of colour' [SV 4, 204-5]. And again, writing about the luminous landscapes of the Swedish artist Carl Fredrik Hill (1849-1911), he remarked how 'everything flows, is mystical. The eye works, seeking a firm point, which is never found. Therein lies the pleasure. ${ }^{11}$

Like the element of imaginative play in both the creation and the reception of the work of art, this pleasure, what Roland Barthes would call jouissance, is central to the theory of artistic creation that Strindberg developed in his essay on 'The New Arts', which he wrote in Austria in 1894 to introduce the paintings that he brought with him to Paris to what he rightly anticipated might be a sceptical public. Indeed, like many of his works during this period, the essay was written in French, and jouissance is precisely the word that he uses for an art in which meaning continually multiplies and where closure seems constantly deferred. Unlike Cantzler's detailed realism, for example, which loses its power to please once there is nothing new to be seen, he describes how, in 'modernist paintings'

... one sees at first only a chaos of colours; then a likeness begins to emerge; it resembles - but no, it resembles nothing. All at once a point defines itself, like the nucleus of a cell; it grows, the colours group themselves around it, accumulate; it forms rays which sprout branches, then twigs, 
as ice crystals do on a windowpane... thus the image is presented to the spectator, who has participated in the act of procreation of the picture. And even better: the painting is always new; it changes according to the light, never wears out, and is rejuvenated by the gift of life..$^{12}$

In describing here the creation of one of his own paintings, Wonderland, the anti-naturalistic aesthetic on which these pictures are based is evident. As works of art they no longer pretend to present the lineaments of a realistically observed world or even, as Zola argued art should, reproduce a corner of creation viewed through a temperament. Rather, they comprise what Hazlett chided in Turner, namely 'the representation not properly of the objects of nature as of the medium through which they were seen.' Governed merely by a vague design in the artist's mind, such paintings emerge from the interplay between the materials he is using and his own rapid interventions with palette knife or fingers, and much in the process is left to the intervention of chance. Once finished, the spectator's imagination is then free to complete what the artist has produced by unconscious means.

Strindberg had touched on these theories two years earlier, in a brief letter to his friend, the painter Richard Bergh, in which he coined the phrase skogsnufvismen to describe this new art form: 'I have a number of oil studies to show you, painted from the imagination,' he told Bergh. 'A "new direction" that I have discovered myself and call skogsnufvismen' [IX, 40]. The customary English translation of skogsnufvismen, 'wood-nymphism', is hardly adequate, and need not be retained here, but a passage in 'The New Arts' helps clarify what Strindberg had in mind: 'You all remember the fairy tale about the boy out strolling in the woods, who comes upon a wood nymph [or skogsrå in Swedish]. She is as beautiful as the dawn, with emerald-green hair, etc. As he draws closer she turns her back, which now resembles a tree stump. Clearly, the boy never saw anything but a stump, and his lively imagination invented all the rest. ${ }^{13}$

The capricious creativity in evidence here suggests that phenomena are no longer to be seen as passive objects awaiting recovery by the recording artist but intense agents in the drama of the mind that has released them. What this passage also implies is that Strindberg now perceives nature as a fellow maker and creator. Hence he no longer feels compelled simply to transcribe what he calls 'the banal facts' of the phenomenal world: nature remains his touchstone but instead of reproducing an artless landscape in circumstantial detail, as he had accused Cantzler of doing, he sets out to emulate what he' understands to be nature's own artistic practice; in short, not to create works of art that imitate nature, but to emulate nature and create new works as he believes nature itself does, with prodigal turns of fancy. Moreover, if nature comprises a series of works of art, then this supposes a creator whose handiwork, as Strindberg 
studies it in detail in the miniature universe of the Jardin des Plantes in Paris, is to be discerned in what, in another letter, he calls 'nature's own visible pictures' [XI, 157], those images or artifacts in the natural world that bear a striking resemblance to his own artistic caprices. Thus, beginning with chance he has paradoxically discovered design, so infinite does what he calls the coherent pattern in the great, apparent chaos now appear to him. In short, the natural world is a modernist work of art, to the external eye an apparent chaos but one in which the internal eye can everywhere discern a world of similarities, coincidence, and repetition in every thing; the universe appears to him as a vast sign system with its creator's signature impressed on all things, from a moth's wing to the surface of meteors and the shells of crabs, and from the atomic weight of metals to the circumstances of his own life, which he was now once more prepared to try to recover in literature, in the autobiographical fiction Inferno.

From the end of the previous decade, with the novel By the Open Sea, Strindberg had in fact been exploring, with ever greater urgency, a tension between chance, coincidence and discontinuity on the one hand, and order, relationship and coherence, on the other, and the personal drama of his life during these years should not be seen as a mental and emotional crisis that he passively suffers and patiently endures but a process that is actively encouraged and frequently prompted by Strindberg himself. His life is a skogsnufvistisk work of art, lived as he admits in Inferno, in an improvisatory manner, which makes it more amusing, and the picturesque events of his bohemian existence during this period, including his tragi-comic courtship and marriage to Frida Uhl, which ended on a traffic island outside the department store Printemps in Paris, among a potpourri of fin-de-siècle Satanists, Alchemists, Theosophists and Black Magicians, easily diverts attention from other aspects of a process in which the middle-aged Strindberg painfully renews himself and embarks in search of that new world which inspired him in the canvases of his friend, Gauguin. 'I, too, am beginning to feel an immense need to turn savage and create a new world,' he told Gauguin, at the end of a long letter that Gauguin used as the preface to a catalogue of his paintings that were sold at the Hôtel Drouet in February 1895, just prior to his final departure for Tahiti [SS 54, $329 ; 2,531]$. Or, as a fugitive note in Strindberg's hand from this period affirms: 'Tired of the world. Created a new one' (Led vid världen. Skapade mig en ny).

The first literary product of this new approach was his Occult Diary, which he began in 1896 and continued until 1908. With its various insertions, sketches and later additions, the Diary is not only a catalogue of this universe of signs but a repository of objets trouvés, ready-mades and frottages, a kind of Merzbau of the mind that the succeeding generation of Hans Arp, Max Ernst and André Breton would have recognized as l'hasard objectif of Surrealism, 


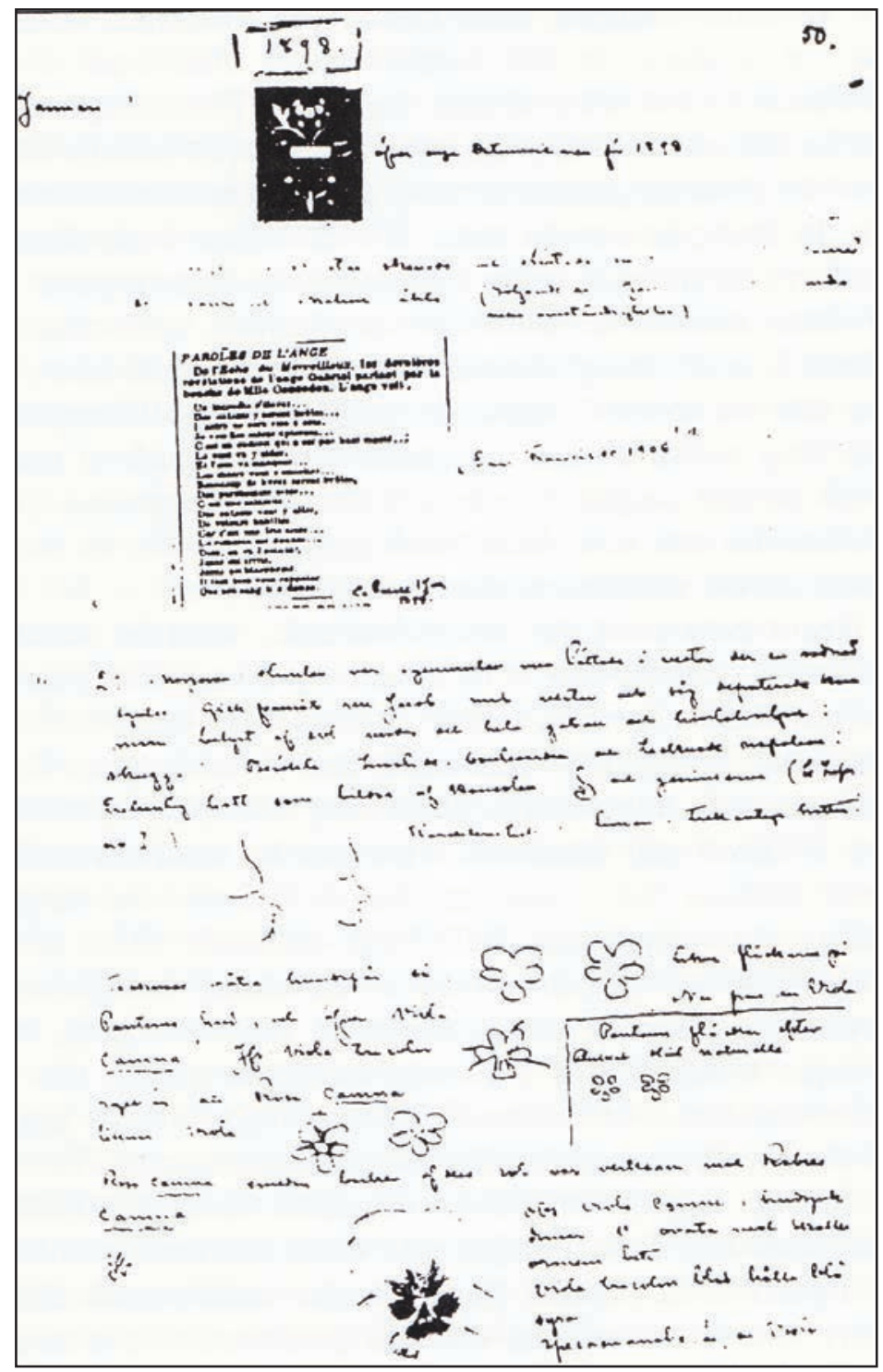

Representative page, with sketches, The Occult Diary 
those apparently random happenings which nevertheless betoken an underlying order in life. There is, for example, considerable similarity between Ernst's account of frottage in Beyond Painting (1948) and Strindberg's proposal in one of his letters to illustrate the Book of Job in an occult fashion with illustrations that would look like a piece of paper that had been crumpled and rubbed with charcoal [XI, 288]. Likewise, there is common ground between Arp's definition of "The "law of chance" which embraces all laws and... can only be experienced through complete devotion to the unconscious, ${ }^{14}$ on which he drew in creating his Papiers déchirés (Torn Papers), and Strindberg's comment in a letter to the Theosophist, Torsten Hedlund, on how 'One sometimes gets interesting and living pictures by crumpling paper or tinfoil. But one must not do this with intent; just take care to observe the result when it occurs. One receives a letter or parcel which makes this or that impression. One crumples up the paper and throws it in the wastepaper basket without further thought. Don't you think that the hand which crumpled it up was unconsciously steered and expressed great emotion, perhaps [in] a whole series of images?' [XI, 289].

Of all Strindberg's literary texts, it is the autobiographical fiction Inferno which most strikingly records the details of this skogsnufvistic world. Among some lumps of coal left over from his chemical experiments, for example, he discovers what he describes as 'a splendid group of two drunken gnomes in billowing garments embracing each other, a masterpiece of primitive sculpture' [SV 37, 71], and when he shows them to his artist friend (in reality Edvard Munch but portrayed here thinly disguised as the Danish painter 'handsome Henrik'), the latter mistakes them for a group of figures by the Norwegian artist and illustrator Theodor Kittelsen (1857-1914). On another occasion, pillows crumpled by chance, unconsciously, during a restless night assume human shapes in the manner. of Michelangelo, and even the pansies in his window box seem to nod at him mockingly after his attention has been drawn to a lithograph of a Viking ship in which the various human figures are depicted with pansies instead of heads. Again, walking down a Paris street he describes 'the statue of a knight pointing to an inscription in charcoal on a whitewashed wall. The intertwined letters $F$ and $S$ made me think of the initials of my wife's name [Frida Strindberg]. She loves me: still! A second later a light dawned upon me when the inscription decomposed before my eyes into the chemical symbols for iron and sulphur (Fe and S) and revealed to me the secret of gold' [SV 37, 69]. That Fe and $S$ reveal the secret of a substance which in chemical nomenclature begins with the initial letters of his own first name, $\mathrm{Au}$, is a coincidence that not even Strindberg appears to have noticed, although elsewhere, in a note on goldmaking from this period he observes, in green crayon: 'Hôtel Orfila, 1896. $1896=196=$ [the atomic weight $]$ of Au'. 

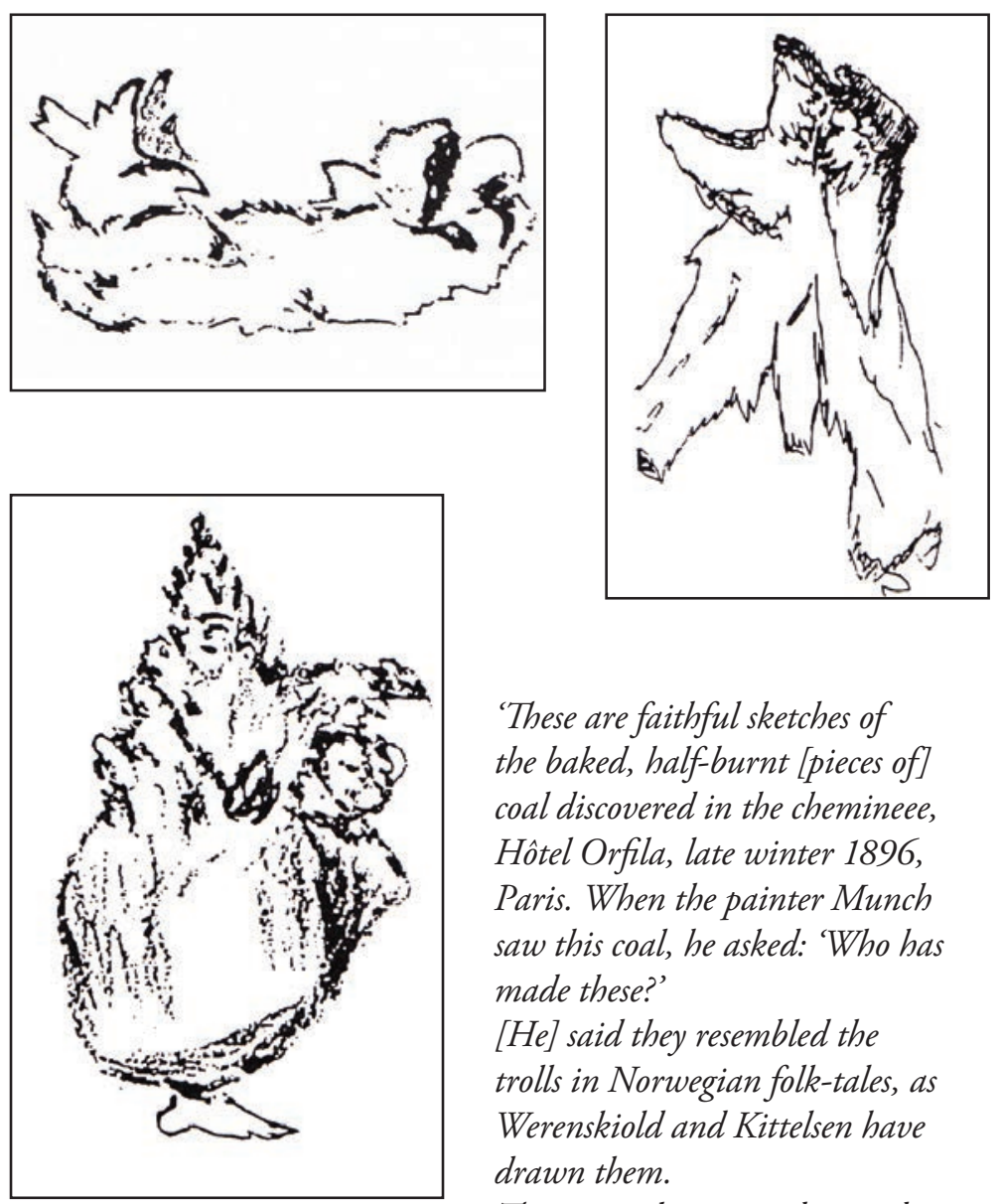

'These are faithful sketches of the baked, half-burnt [pieces of] coal discovered in the chemineee, Hôtel Orfila, late winter 1896, Paris. When the painter Munch saw this coal, he asked: "Who has made these?'

[He] said they resembled the trolls in Norwegian folk-tales, as Werenskiold and Kittelsen have drawn them.

The originals are in a box and more faithful than these copies.'

Charcoal sketches. Trolls. Hôtel Orfela, 1896. 
Nothing, in short, lacks significance, and everything in Paris, down to the detritus of its streets, is pregnant with meaning. Unlike Strindberg's first major prose narrative, The Red Room, which follows so many great nineteenthcentury novels in dealing with the first encounter of a young man from the provinces with the duplicity of urban life, Inferno, as it maps the unconscious, subterranean life of the city, looks forward to the modernist fictions of James Joyce or (since this is Paris) André Breton's Nadja (1928) or Louis Aragon's Le Paysan de Paris (1926). As is the case with Bréton and Aragon, the metropolitan landscape, with its street signs, window displays, hoardings, and privileged places, as well as its chance encounters, random events and objets trouvés evokes a magical causality, in which the ridiculous associates with the sublime and the marvellous erupts within ordinary life.

In conclusion however, and as an indication of the way in which Strindberg's skogsnufvismen might function in the hallucinatory but still mundane world of his later drama, I should like to conclude with a brief comment about one of his most complex works, The Ghost Sonata, which was written in 1907, over a decade later than the period on which I have been focusing. One of the most prominent of the many motifs which Strindberg's associational method inserts into the intricate patterning of this masterpiece of theatrical modernism, is a large statue of Buddha, with a bulb on his knees, from which there rises the stalk of an Ascalon flower. It stands on the tiled stove in the Daughter's room, where the final scene of the play is set, a room that is also filled with hyacinths. Quite clearly, both the statue and the flowers are significant, and the Student, who by this stage of the play has emerged as a commentator on its action, in fact discourses at length on their meaning:

The bulb is the earth which rests on the water or lies in the dust;... Buddha thus sits with the earth on his knees, brooding over it, watching it grow outwards and upwards, transforming itself into a heaven. This poor earth shall become a heaven! That is what Buddha is waiting for! [SV 58, 212]

No doubt! And most eloquent! But it is worth remembering that among Strindberg's various notes and drafts for the play in the Royal Library in Stockholm there is a double-sided handbill from the Stockholm Export-Import Firm of Paul Peters. On the first side it carries an advertisement for 'One of nature's wonders in the world of flowers!', namely a Sauromatum venosum whose bulb produces a flower without needing to be planted in the earth or moistened. On the reverse, it advertises a statue of Buddha with a Sauromatum venosum at his feet. The Buddha on its own costs 2 kronor 50 öre, with the bulb 3 kronor 75 . Postage is free but packing costs an additional 30 öre [SgNM $4: 4,4]$. Was it chance that delivered this piece of junk mail to Strindberg's door? If so, he made excellent use of it. 


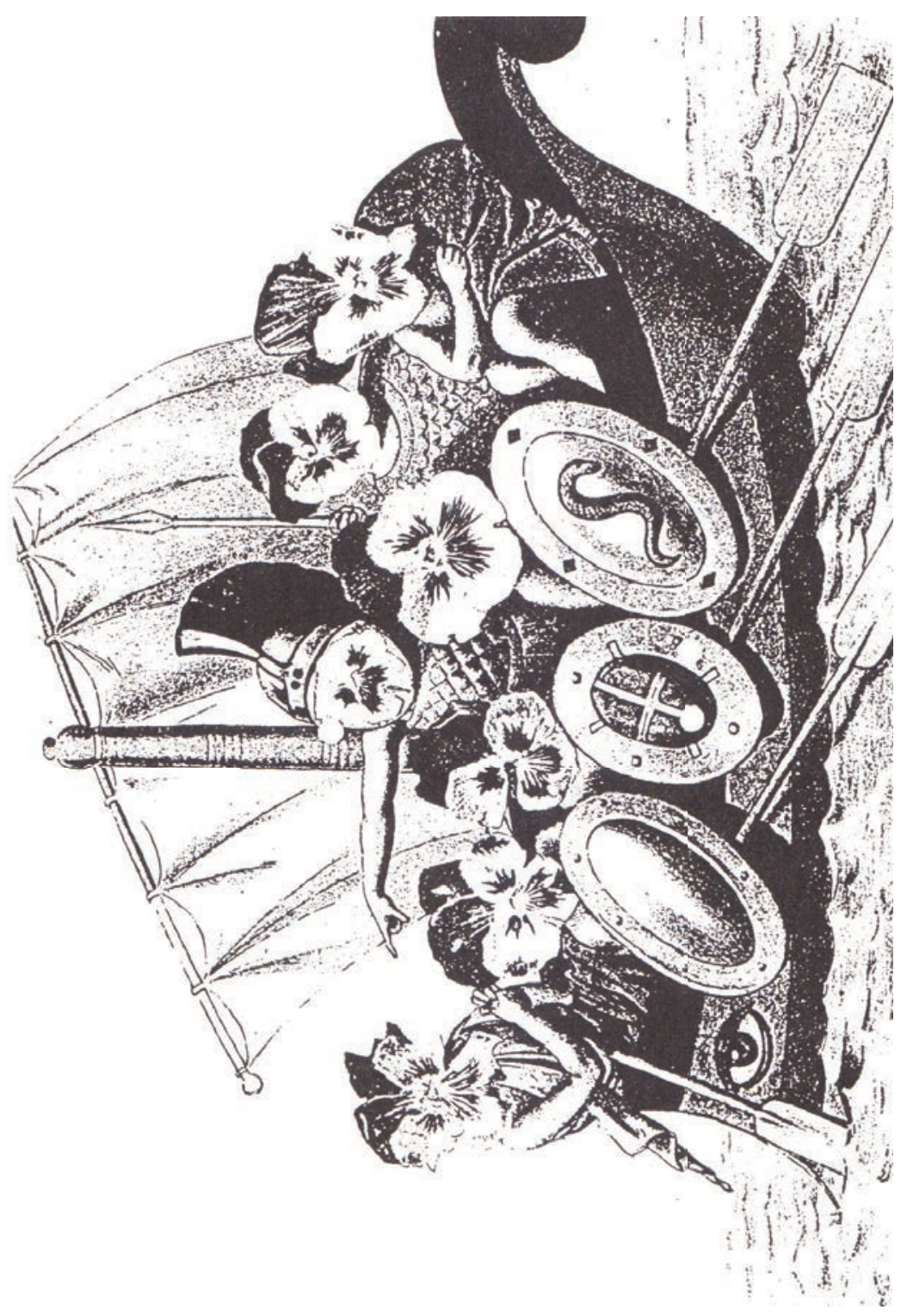

The Viking Ship 


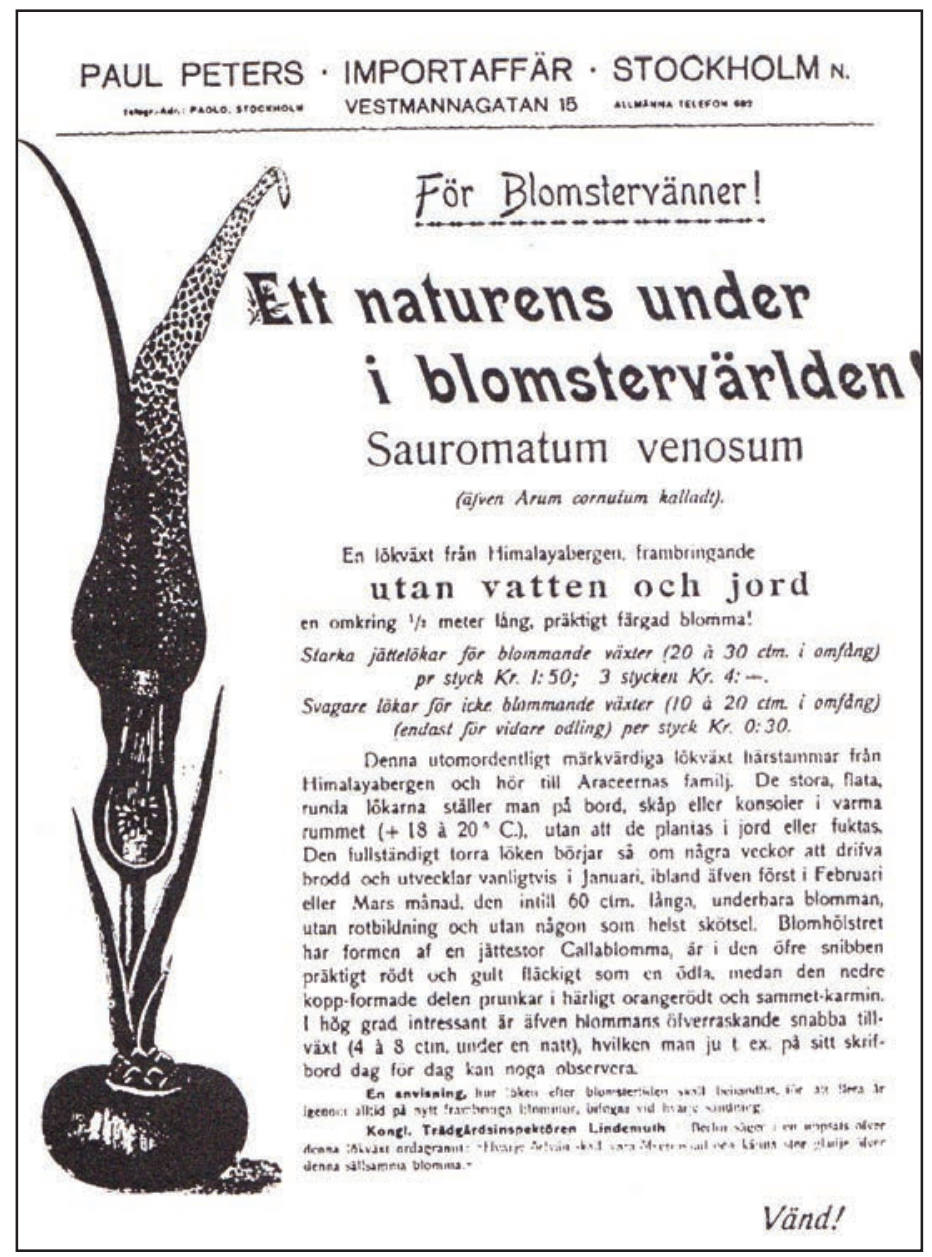

Advertising flyer, Paul Peters Import Business, p.1 


\section{Sàsom en \\ Originel, präktig rumsprydnad}

rekommenderas:

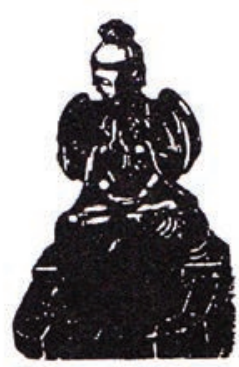

\section{Buddha-Statyen,}

konstnärligt framstalld $i$ elfenbenmassa efier ett i Grassi-Museet $i$ Leipzig befintligt original.

Liksom en oflergalva har den vid Himalays inhernska brödformade "Sauromatum venosum"-lōken blifvit lagd framfôr aigudabildens fötter.

Detta förcmal torde sàrskildt lämpa sig till presenter och rckommenderas tillsamman med d andra sidan omtalade vãxtlōkarne $i$ synnerhet som en

\section{välkommen och högst intressant Julgáfva!}

Pris for Buddha. Figuren i elfenbenmassa $(16 \mathrm{~cm}$. hög) . . . . . . . . . Kr. 2:50

I forening med en jättelök for blommande växler . . . . . . . . . . . . 3:75

For ldda och forpackning beräknas 30 orc.

Försändandet under efterkraf och ofrankcradt, i Stoskholm fritt hemsändt, genom

$$
\text { Paul peters, }
$$

Stockholm, Vestmannagatan 15.

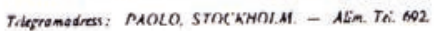

Advertising flyer, Paul Peters Import Business, p.2 



\title{
11. Strindberg and Musical Expressionism in Vienna
}

\author{
They really are, as Webern wrote to me yesterday: \\ "emanations from God... Schönberg - Strindberg" \\ Alban Berg
}

In 1906, on the eve of his departure for New York and the musical directorship of the Metropolitan Opera, Gustav Mahler is reported to have asked a group of younger musicians, including Schoenberg, Berg and Webern, 'What do you fellows think about Dostoyevsky nowadays?' According to Alma Mahler, who recalls the encounter in her memoirs, 'A chorus of youthful voices replied: "We don't bother with him any more. It's Strindberg now".' Although he dates the occasion two years later and attributes the response to Mahler's question to the lone voice of Anton von Webern rather than to a youthful chorus, Hans Heinz Stuckenschmidt tells much the same story in his standard biography of Schoenberg, as does Willi Reich, in his account of Alban Berg's life and works. ${ }^{2}$ Clearly, the encounter was perceived as in some way a defining moment, like a previous 'moment of literary history' [IX, 123; 2, 452] that Strindberg had himself had occasion to chronicle in a letter to the Swedish diplomat and novelist, Birger Mörner, from Berlin in January 1893, when, at a party following the première of his play Heimat on 8 January 1893, the German dramatist Hermann Sudermann had acknowledged the impact of Scandinavian writers on contemporary Germany by observing: 'Vom Norden her kommt uns das Licht!' [IX, 123; 2, 452].

Although there have been numerous intimations of Strindberg's relevance for the Vienna of Musil, Freud, Wittgenstein, Weininger, Kokoschka and Kraus in general and that of Viennese musical expressionism in particular there have been few attempts to assess the role that Strindberg played in the emergence of modernism in Austria with any precision. Writing of his first extended visit to Frida Uhl's home at Dornach in Upper Austria in 1893-4, Olof Lagercrantz, in his biography of Strindberg, invites us to imagine him in that summer of 1894 as existing in the same space with Freud, Mahler, Kraus, and Schoenberg - who was 
obsessed by Strindberg, according to Theodor Adorno, ${ }^{3}$ but he does not expand on this tantalizing juxtaposition. Nor do the two seminal studies of this period in English - Carl Schorske's Fin-de-Siècle Vienna or Allan Janik and Stephen Toulmin's Wittgenstein's Vienna - consider his possible influence on the culture they are dissecting even though both the linguistic scepticism that preoccupies Janik and Toulmin or the loss of certainty regarding the nature of individual identity and the collapse of confidence in the coherence, form and order of the social and the natural worlds that concerns Schorske might, given his documented importance in the German-speaking nations at this time, have directed their attention to Strindberg. Like Mach and Musil he had articulated the breakdown of the traditional coordinates of time and space in the prefatory note to A Dream Play; like Loos, Kraus or Schoenberg he was an enemy of the merely ornamental and sought, like the Student's father in The Ghost Sonata, a language that would express those social truths that convention contrived to conceal; like Freud he found a way of rendering both dreams and the unconscious audible and visible; and no established writer of his generation had surely paid greater attention to what Schorske, taking his cue from Hofmannsthal, describes as 'a world which... was characterized by Das Gleitende: "[T]he nature of our epoch," [Hofmannsthal] wrote in 1905, "is multiplicity and indeterminacy. It can rest only on das Gleitende [the moving, the slipping, the sliding], and is aware that what other generations believed to be firm is in fact das Gleitende". ${ }^{4}$

In general, the pioneering role of Josef Jarno at the Theater in der Josefstadt in promoting Strindberg's work on the Viennese stage has also received little recognition. ${ }^{5}$ As in Paris in the mid-1890s Strindberg's initial reception in Vienna had as much to do with his notoriety as a woman-hater as with his standing as a dramatist, and his writings were readily enlisted to play a part in the sexual politics of a period obsessed with the analysis and representation of Woman, 'Das Weib'. This is certainly the case where his impact on Weininger and Kraus is concerned. Strindberg, of course, corresponded briefly with both of them while Emil Schering, as his translator, wrote frequently to Kraus, on his own as well as Strindberg's behalf, and placed a number of Strindbergian texts that he had culled from the pages of his ongoing German edition of Strindberg's works, in Kraus's journal, Die Fackel. Indeed, between 1903 and 1912 Strindberg, with Schering as an interested intermediary, was one of the most frequent contributors to Kraus's journal, where his work continued to appear even after Kraus had severed his connections with almost all his other contributors. ${ }^{6}$

Weininger, meanwhile, had sent Strindberg a copy of Geschlecht und Charakter (Sex and Character) in which he referred to The Father as a 'mächtige Tragödie' and utilized Creditors to prove that woman has no soul and is only a sexual complement to man, shortly after its publication in May 1903. 
Strindberg responded with a brief note in which he exclaimed, 'Finally - to see the woman problem solved is a deliverance for me, and so - accept my deepest admiration and my thanks!' [XIV, 274; 2, 700], and following Weininger's suicide that October, he also wrote a short necrology which was originally published by Kraus in Die Fackel as 'Idolatrie, Gynolatrie: Ein Nachruf von August Strindberg. There, as in his posthumously published Swedish essay on Weininger, he gives a brief exposition of the latter's theory of sexual difference in which man is perceived to be a superior moral creator and woman an erotic mediocrity, devoid of intellect, a wanton whose love 'comprises fifty percent rutting and fifty percent hate' [SS 54, 413]. He concluded the essay by laying 'a wreath on [Weininger's] grave because I honour his memory as the memory of a valiant male thinker' [SS 54, 414].?

However, as Alma Mahler's anecdote suggests, Strindberg also held an important, if less publicized, significance for the composers of the Second Viennese School, Schoenberg, Berg, and Webern. Of these, Webern was the only one actually to set a Strindberg text to music. This was in the song 'Schien mir's, als ich sah die Sonne', a setting of lines from Strindberg's paraphrase of part of the Icelandic 'Song of the Sun' in The Ghost Sonata, which forms one of Webern's Four Songs for Voice and Piano, Op. 12. However, something of the veneration that he felt for Strindberg may be gauged from a comment reported, with some additional remarks, by Alban Berg in a letter to Schoenberg:

... you must believe me, when I swear to you that your works belong to the very, very highest, that they can only be considered in company with those of Beethoven, Mozart, Wagner, and Mahler and that all the others are beneath them. They really are, as Webern wrote to me yesterday: "emanations from God [Ausstrablungen Gottes]:

$$
\begin{aligned}
& \text { Beethoven - Kant } \\
& \text { Wagner - Schopenhauer } \\
& \text { Schönberg - Strindberg" }
\end{aligned}
$$

Meanwhile Berg, though he did not use Strindberg directly in his work was nevertheless given to his frequent and enthusiastic praise. Speaking for his generation in a letter to his wife, Helene, dated 16 July 1909, he lists as 'our gods, Maeterlinck, Strindberg, Mahler, [and Richard] Strauss,, later he engagingly draws her attention to Strindberg's achievement in a variety of fields, as a dramatist, autobiographer, and novelist as well as the author of 'all the other works I've not yet read but am sure are just as fine', this in contrast to Knut Hamsun who 'wrote five masterly novels as a young man... [but] has not produced anything since..$^{10}$ Berg in fact acquired Strindberg's collected works as they appeared in German, and his copies of them are heavily annotated. ${ }^{11}$ Indeed, like Schoenberg he knew the prose works as well as, if not better than, 
the plays and appears to have derived his knowledge of Strindberg mainly from his printed texts rather than from their performance in the theatre. Thus, in the same letter, it is Strindberg's 'colossal stature as a writer' rather than his standing as a dramatist on which Berg comments, and he goes on to stress his role as 'one of the most remarkable personalities of our time. We can't condemn any of his works out of hand!' Likewise, two years later, on 20 November 1911, he listed 'a book by Strindberg' along with 'a solitary tree... and a symphony by Mahler' as examples of God's finest creations, ${ }^{12}$ and the following year a letter from Berg to Webern contains a glowing tribute to Strindberg, occasioned by the dramas Advent and Crimes and Crimes. According to Berg, both plays are filled with a profound musicality, ${ }^{13}$ although he did not pause, as Evert Sprinchorn has done, to analyse the latter in terms of sonata form and argue that in this example of Strindberg's theme-centred, post-Inferno dramaturgy, '[T] he musical techniques of varying the principal themes and of transferring them from one voice to another are carried further... than in any of his other works.' ${ }^{14}$ Moreover, on at least one occasion Berg considered taking a Strindberg play as the basis for an operatic score. When, in October 1912, Schoenberg asked him if he had 'ever thought of writing something for the theater?' and added: 'Just see that you don't take the Dream Plays away from me, for I'm considering them myself. But some other Strindberg work', ${ }^{15}$ Berg replied: 'if only I had a suitable text: for the theater. I was already considering Strindberg's Chamber Plays, and now that you suggest Strindberg that of course seems all the more compelling.' ${ }^{16}$

But if Berg was an enthusiastic reader, Schoenberg - as usual - went further. Indeed, during his expressionist period which encompasses, among other works, the monodrama Erwartung (1909), the 'drama with words', Die glückliche Hand (begun 1908, completed 1913), and the oratorio fragment Die Jakobsleiter, the first textual sketches of which date from 1915, Strindberg is present as part of the complex intertextuality of Schoenberg's works. Like Berg he acquired Schering's edition as it was published by Georg Müller, beginning in 1902. In 1913, for example, his library contained 28 volumes by Strindberg, well ahead of Maeterlinck 18, Kraus 12, Dehmel 10 and Rilke $9,{ }^{17}$ and according to the musicologist John Crawford, who quotes from an unpublished letter that Schoenberg addressed in 1951 to a certain Jake Johnson in Stockholm, he had read all those works of Strindberg translated into German 'numerous times', which 'has made me one of his greatest adherents.' ${ }^{18}$

It is also possible to identify a number of circumstantial associations between Schoenberg and Strindberg as well as several points where their ideas and practice converge. There are, for example, their mutual admirations or associations in inter alia the works of J.P. Jacobsen, who provided Schoenberg with the text for his Gurrelieder (begun 1900, completed 1911) and whose novel, Fru Marie Grubbe (1876), Strindberg once considered dramatizing; 
Richard Dehmel, who Strindberg had known in Berlin in 1893, and whose Weib und Welt (Woman and World, 1896) formed the basis of Schoenberg's first masterpiece, the string sextet Verklärte Nacht (Transfigured Night, 1899); Maeterlinck, a common admiration around the turn of the century, of course; and Balzac, whose Seraphita became one of Strindberg's canonical books from the Inferno period on, ${ }^{19}$ and which Schoenberg wished to make into a stage work spanning three evenings, complete with the angelology of Swedenborg, whom he also read. ${ }^{20}$ 'Do you know it?', he asked the painter Wassily Kandinsky, in 1912: 'Perhaps the most glorious work in existence. I want to do it scenically. Not so much as theatre, at least not in the old sense. In any case, not "dramatic". But rather: oratorio that becomes visible and audible. Philosophy, religion that are perceived with the artistic senses..$^{21}$

This reaching after new genres to express finely tuned and frequently extreme states of experience is itself a common feature of both their work. And just as Strindberg explores states of half-reality and dream in Part I of To Damascus and A Dream Play where, according to his prefatory note, 'Time and place do not exist; on an insignificant basis of reality the imagination spins and weaves new patterns' [SV 46,7], so, in one of his principal expressionist works, the brief operatic score Erwartung (Expectation) in which he abandons every conventional kind of formal linkage, including leitmotiv and thematic repetition, Schoenberg carries to an ominous conclusion the tendency prevalent in the late Strindberg as well as in Wagner - to monodrama - which is part of that shift in drama away from strenuous or decisive stage action to narration and reflection that Szondi has charted in his influential Theorie des modernen Drama. ${ }^{22}$ Indeed, in a reference to To Damascus in his essay on 'Art and the Moving Pictures', Schoenberg reveals his own aspiration also to renounce 'the law of "unity of space and time" that Strindberg had demolished in his prefatory note to A Dream Play. ${ }^{23}$

More immediately, however: the nightmare atmosphere of Erwartung, in which a woman in a dark wood stumbles across the body of her lover whom she may herself have slain is (as so often in Schoenberg) both a deeply personal, partly autobiographical document and a kind of case study (the libretto was written at Schoenberg's request by Marie Pappenheim, the sister of the 'Anna O' made famous by Freud and Breuer's Studies on Hysteria) in which his atonal music becomes a language expressive less of the Schopenhauerian will than of the Freudian unconscious. Given Schoenberg's aesthetic its music is expressive as much of the composer himself as it is a realistic representation of the subject through which he chooses to express himself. As in a great deal of Strindberg's work, from To Damascus on, this aesthetic no longer seeks faithfully to reproduce the surface, the anecdote, but to express an inner world which manifests itself at its most immediate in the 'Schrei' of Expressionism, of which Erwartung is 
an extended example. 'In reality, there is only one greatest goal towards which the artist strives,' Schoenberg writes: 'to express himself. ${ }^{24}$ And again: 'art belongs to the unconscious! One must express oneself! Express oneself directly! Not one's taste, or one's upbringing, or one's intelligence, knowledge or skill. Not all these acquired characteristics, but that which is inborn, instinctive. ${ }^{25}$ And to realize his aims he has at his disposal what he believes to be the form of expression that is least contaminated by the superficies of the world: music. For, adopting the theory of Schopenhauer and Wagner that music apprehends the essence of the world directly in sounds, whereas verbal language is a mediated, secondary form of expression, he claims that 'so direct, unpolluted and pure a mode of expression is denied to poetry, an art still bound to subject matter. ${ }^{26}$

And yet, as with Strindberg, what is important for Schoenberg is the need for self expression rather than the particular medium through which the individual artist elects to express himself. Just as Strindberg's artistic experiments during the early 1890s, conducted in accord with the theories of aleatory creation that he advanced in the vivisection 'The New Arts! or the Role of Chance in Artistic Creation', gave him the freedom to develop a new artistic language that would in due course contribute to his later work as a dramatist, ${ }^{27}$ so during the years in which he abandoned the security of the tonal system, which were years of great personal as well as artistic upheaval, Schoenberg also found in painting an alternative means of expression. ${ }^{28}$ Moreover, while it is easy to overstress the affinity (Strindberg after all no more read Freud's books than he heard Schoenberg's music), the fact remains that in the early years of the century all three men were seeking a language - theatrical, musical, oneiric and verbal - in which to express the unconscious. As Donald Mitchell observes, of Schoenberg:

$\ldots$ in the years when Freud was diving into - the Unconscious, so too was Schoenberg; because in a very real sense, having abandoned tonality, and with it the 'subconsciously functioning sense of form which gave a real composer an almost somnambulistic sense of security in creating, with utmost precision, the most delicate distinctions of formal elements', Schoenberg had only his Unconscious to look to as a potential source of the means and principles of unity and organization which would replace the lost paradise of tonality. ${ }^{29}$

Strindberg likewise came to believe 'that whatever an author does in his fever is right' [VII, 103; 1, 280], and in his dramatic writing he worked towards a form of theatre in which musical values predominate. As he remarked, of the Chamber Plays of 1907, 'the motif determines the form' (motivet betingar formen [SS 50,12]), and both there, and in To Damascus and A Dream Play he developed the possibilities of a dramaturgy organized in terms of its themes rather than the inexorable logic of a determining linear causality. Moreover, as 
Schoenberg said he wished to do, he makes music with the media of the stage, as in the closing directions of the first scene of part one of To Damascus, where the spoken word is augmented by the concrete languages of the stage, including lighting, sound, gesture, costume and movement: '[The Lady] draws the veil from her face, kisses him hastily on the mouth and hurries out. The Stranger stands for a moment astonished and dazed. A high-pitched chorus of women's voices, approaching a shriek, is heard from the church. The illuminated rose window suddenly darkens; the tree above the bench stirs; the Mourners rise from their places and look up at the sky, as if they were witnessing something unusual and terrifying' [SV 39, 38].

More specifically, however, his biographer, H.H. Stuckenschmidt maintains that Schoenberg gave credence to the Strindbergian idea that suffering endured on earth was a consequence of wrongs committed in a previous existence, and he goes on to argue that 'His spiritual development had grown in a similar way to Strindberg's. ${ }^{30}$ Stuckenschmidt outlines the vicissitudes of Strindberg's development up until the autobiographical fragment Jacob Wrestles (Jakob brottas) of 1898; he then maps them roughly on to the biography of Schoenberg that he is engaged in writing, and implies that their shared initials - A S - held an almost talismanic significance for Schoenberg. ${ }^{31}$ In fact, as Stuckenschmidt points out, the autobiographical prose fragment Jacob Wrestles 'moved Schoenberg deeply and stimulated him creatively for years. He spoke about it to his most trusted friends, not only Berg and Webern, but also Erwin Stein, Heinrich Jalowetz and Karl Linke', and entertained plans to set it to music. Indeed, Berg told Webern in a letter that '[Schoenberg] wanted at that time to write to Strindberg in detail, and even had the idea of asking Strindberg for a text. ${ }^{32}$

Originally conceived as an independent work Schoenberg then had the idea of making this setting of Jacob Wrestles part of the gigantic conception he had for a text based on Balzac's Seraphita, in which Jacob Wrestles would serve as a kind of anterior narrative or pre-history for the figure of Wilfried in Balzac's novel. This emerges from a letter to Richard Dehmel, in which Schoenberg outlines his search for a libretto that would evoke a situation not unlike that in which Strindberg had found himself in the mid-1890s, that is, the troubled history of an atheist with some residue of faith who follows a path through materialism, socialism and anarchism on the way to a new encounter with God. 'For a long time,' Schoenberg wrote:

I have been wanting to write an oratorio on the following subject: modern man, having passed through materialism, socialism, and anarchy and, despite having been an atheist, still having in him some residue of ancient faith (in the form of superstition), wrestles with God (see also Strindberg's 'Jacob Wrestling') and finally succeeds in finding God and becoming 
religious.... Originally I intended to write the words myself. But I no longer think myself equal to it. Then I thought of adapting Strindberg's 'Jacob Wrestling'. Finally I came to the idea of beginning with positive religious belief and intended adapting the final chapter, 'The Ascent into Heaven', from Balzac's 'Seraphita. ${ }^{33}$

Clearly, Schoenberg recognizes his own idea in the general pattern of Strindberg's experience up to and including not only Jacob Wrestles, but also Inferno and To Damascus, for in the same letter he insists that 'It is not through any action, any blows of fate, least of all through any love of woman, that this change of heart is to come about', ${ }^{34}$ thus departing from one of the fundamental structural patterns in both these works, in the first of which the protagonist is depicted as having to choose between love and knowledge, and in the second of which a woman is instrumental in the hero's equivocal return to faith.

The oratorio in the form outlined here remained unwritten. However, in 1915 Schoenberg then wrote the text for a Symphony for Soloists, Mixed Choir and Orchestra - a Totentanz der Prinzipien - which he published, along with Die glückliche Hand, Requiem and Die Jakobsleiter as one of four Texte in 1926. Described by Stuckenschmidt as the gloomiest of all Schoenberg's inventions, ${ }^{35}$ this scenario, like other sketches from the same period in Rufer's catalogue of Schoenberg's works, continues to echo the Strindbergian situation of Inferno, Jacob Wrestles and To Damascus. Its first movement is entitled 'Turning-Point in Life' while the final section depicts 'The faith of the "disillusioned one"; the union of objective, sceptical consciousness of reality with faith', and concludes with the strikingly Strindbergian observation: 'In the simple is concealed the mystical'. ${ }^{36}$

Schoenberg's interest in Jacob Wrestles eventually bears partial fruit in Die Jakobsleiter (Jacob's Ladder), the enormous but fragmentary torso of an oratorio for which he commenced writing the music in 1917. Having written the first half in short score, he was called up for army service and never again succeeded in finding a spontaneous continuation that might have led to the completion of the work. Like Strindberg, Schoenberg worked rapidly in concentrated periods of inspiration, and what remains of Die Jakobsleiter, where there is little if any residue of Jacob Wrestles, was orchestrated posthumously from Schoenberg's sketches by one of his pupils, Winfried Zillig.

By common consent, however, it is the earlier 'drama with music', Die glückliche Hand (The Happy Hand), composed with uncharacteristic difficulty between 1910 and 1913, that bears Strindberg's imprint most clearly. In effect a monodrama like Erwartung it depicts its singing protagonist, the Man, trapped in a triangle in which the other coordinates are the Woman and the Gentleman, both mimed roles and projections of the Man's thoughts and the events that give rise to them. There is also a chorus of twelve speaking voices, six men and six women, whose faces appear through rents in a dark violet 
curtain (rather like the chorus of faces that appear in A Dream Play and Queen Christina) and ask the Man, in both the opening and the closing scenes, why he cannot avoid repeating the drama that we are witnessing here. In this the Man, who can plausibly be seen to represent the artist or creator, is discovered lying on the ground with a fantastic cat-like animal with enormous wings crouched on his back. To the sound of mocking laughter the Chorus and the creature disappear, and the Man is eventually approached by a beautiful young woman who offers him a goblet and, as with the love potion in Tristan und Isolde, appears to claim him. But she subsequently grows indifferent to him and he loses her to the 'handsome, genteel' Gentleman; who ravishes her away. In the third scene, the Man is shown Siegfried-like with a bloody sword in 'something between a machine shop and a goldsmith's workshop', along with several workers in realistic workingmen's dress. ${ }^{37}$ Dropping his sword he picks up a piece of gold lying on the ground, lays it on the anvil and, after outfacing the Workers who have been threatening him, he splits the anvil with a single blow and from the cleft draws forth a diadem, richly set with precious stones. The Woman then appears to return to him but ultimately remains with the Gentleman, after toppling a great stone down upon the Man, who is left at the end prone on the ground as in the first scene, with the stone, now resembling the fantastic animal, on top of him.

This very brief account does no more than indicate the general structure of a work that has few words, either sung or spoken, but a great deal of meticulously plotted movement and gesture, which are organized in terms of the accompanying score. There is also a complex lighting plot which at one point specifies a crescendo of light progressing from a dull red to glaring yellow by way of brown, a dirty green, dark blue-grey, violet, dark red, blood red, orange and finally yellow to accompany a crescendo of wind in the orchestra. Thus, Schoenberg develops the action through a fusion of media that recalls the ideas of Scriabin and the theories of tone and colour of his close colleague during several of these years, Kandinsky, rather than the Gesamtkunstwerk of Wagner. Indeed, in their precision Schoenberg's stage directions come as close to musical notation as might have been thought possible before the similarly compressed and tightly controlled theatrical scores of Samuel Beckett, in e.g. Footfalls or Krapp's Last Tape.

Nevertheless, for all its dislocations and gaunt yet evocative suggestiveness (indeed, perhaps precisely because of this) the residue of a plot in Die glückliche Hand has frequently called Strindberg to the minds of Schoenberg's critics. Thus, Egon Wellesz in his pioneering study of the composer observed that 'One is most likely to discover the lines on which this drama is written if one thinks of the chamber plays of Strindberg, for whose works Schoenberg had an extraordinary admiration, ${ }^{38}$ while Theodor Adorno, in his Philosophy of the New Music, had 
no hesitation in declaring that 'The subject of the drama is Strindberg's lonely man who experiences the same failures in his erotic life as in his work. ${ }^{39}$ More specifically, both Karl Wörner, in an essay on the text in the Schweizerische Musikzeitung, and John Crawford, in a study of the work as a Gesamtkunstwerk in Musical Quarterly, draw particular parallels. For Wörner, the central theme is 'the battle of the sexes' (den Kampf der Geschlechter) as it is in The Father and The Dance of Death but treated here with greater abstraction. In barely twenty minutes, Schoenberg, employing the same kind of abstract, categorical characterization that Strindberg had revived in To Damascus, spans the core of a conflict which in Strindberg extends across an entire evening. The heroic role of the artist, and in particular the forging of the gold diadem, also recalls To Damascus. 'Here Schoenberg also found the theme of gold-making... linked to a transformation of the world (Weltreformation), ${ }^{40}$ Wörner argues, with enviable confidence of an episode that is at least as reminiscent of the anvil scene in Siegfried as it is of the gold-making scene depicted in Part Two of To Damascus.

Crawford, meanwhile, sees Die glückliche Hand as an expressionist 'Ichdrama' in which the most important literary influence is Strindberg. To Damascus is again the point of reference, but here, much more interestingly, it is the work's structure as much as the character of its protagonist or the stark sexual conflict on which Crawford dwells. As he points out, what is at first sight the apparently loose structure of both these works is belied by their taut circularity. Each of them progresses towards a central episode (in Strindberg's case the Asylum scene in Part One of To Damascus; in Schoenberg's the forging of the diadem), the stages of which are then largely repeated in the second part, so that - superficially at least - the final image of each work recalls the point at which it began. For as Schoenberg himself observed:

It should be obvious to everybody that the opening scene is identical with the closing scene (except for a few mainly formal variations. I cannot say exactly the same thing twice, with me a repetition is always a further development of the idea). I ask: doesn't one gather from this that (since $4=1$ ) the closing scene could now be followed again by the second? And that this is meant to say: etcetera, every time the same again? ${ }^{41}$

However, with its parenthetical recollection of Kierkegaard's Repetition (1843), this almost querulous observation is in fact as much an anticipation of Beckett's Endgame or Play, where, as in Die glückliche Hand, a whole life, forever repeating itself, is depicted in the course of a few minutes, as it is a specific reference to $T o$ Damascus or indeed The Dance of Death, Crimes and Crimes, The Last Knight and The Protector of the Realm, where Strindberg also employs elements of what he calls 'this contrapuntal form borrowed from music' [SV 61,157]. Thus, as Strindberg remarks in a letter about the first of these plays: 


\section{Strindberg: To Damascus I}

Street Corner

Doctor's House

Hotel Room

Sea
Street Corner

Doctor's House

Hotel Room

Sea

Road

Road

Ravine

Ravine

Kitchen Kitchen

Rose Rose

Chamber Chamber

Asylum

Schoenberg: Die glückliche Hand

1. Chorus, Man

stationary

8. Chorus, Man

stationary

2. Offstage laughter

7. Offstage laughter

3. Scene with Woman,

Gentleman

6. Scene with Woman, Gentleman
4. Workshop
episode

5. Lighting

cresendo 
The art lies in the composition, which symbolizes 'The Repetition' that Kierkegaard speaks of; the action unrolls forwards to the Asylum; there it kicks against the pricks and rebounds back through the pilgrimage, the relearning, the eating of one's words, until it begins again at the same point as the action stops, and where it began. You may not have noticed how the settings unroll backwards from the Asylum, which is the spine of a book that shuts upon itself and encloses the action. Or like a snake that bites its own tail. [XII, 279-80; 2, 624]

In Warner's opinion one further dimension also links Die glückliche Hand with To Damascus, the autobiographical. 'Ihre Kunstwerke sind Selbstbekenntnisse, ${ }^{342}$ he maintains, and just as Strindberg used his drama to explore the inner significance of his personal life with Frida Uhl and her family in Dornach, so aspects of the author-composer's life emerge in Die glückliche Hand, where they achieve symbolic representation. And while, as with To Damascus, it is not essential to know of this autobiographical dimension in order for the play to function in the theatre, the triangular relationship of Schoenberg, his first wife Mathilde, and the young painter Richard Gerstl, in which she initially deserted Schoenberg to live with Gerstl only to return and leave Gerstl to commit gruesome suicide (like the painter Schwarz in Berg's Lulu he cut his throat), does provide an intense existential focus for a drama that otherwise tends towards abstraction. ${ }^{43}$ In this sense, too, of course, Den glückliche Hand has little to do with Strindberg. As Schoenberg wrote to Berg in connection with his opera Moses und Aron, which Berg presumed must have some link with Strindberg's posthumously published world-historical drama about Moses, Through Deserts to a Heredictory Domain (Genom öknar till arfland, 1903):

For the moment I can't remember what ideas Strindberg presents. But mine, my main idea, as well as the many, many explicitly stated and symbolically represented subsidiary ideas, all that is such an integral part of my own personality that Strindberg couldn't possibly have presented anything bearing even a superficial similarity. You would certainly have realized that upon reading it, especially if - and this, as you know is indispensable with my work - you had examined every word, every sentence from various angles. Today I scarcely remember what is mine, what is still mine: but one thing you must grant me (I insist on that): everything I have ever written bears a certain intrinsic similarity with myself..$^{44}$

However, rather than itemize conceivable conjunctions and convergences between Strindberg and Schoenberg, it is ultimately more to the point briefly to consider the role each played in the history of drama and music respectively. 'Die glückliche Hand came into being long before the war,' Schoenberg would 
subsequently write, 'at a time when Realism had already been superseded and Symbolism was also coming to an end. As always in such periods, one felt then that one could go no farther with the old means; that the expressive means had withered and representational possibilities were exhausted. One thirsted for new structures, new contents.'.5 His break with tonality in the years before the First World War and the emancipation of dissonance that accompanied it may be viewed either as in itself the adumbration of a new language or the necessary prelude to such an adumbration in the dodecaphonic serialism to which he moved in the 1920s. In either case, however, he places an emphasis on the expressive values of the smallest musical elements - single intervals, short motifs, etc. - and renounces the relatively stable system of meanings which the tonal system, with what Charles Rosen has called its 'large blocks of prefabricated meaning', ${ }^{46}$ afforded the composer during the nineteenth century. And this renunciation of an exhausted, and consequently uncommunicative, language follows in the wake of Strindberg's similar break with the immediate past in his post-Inferno dramas, where he abandons the plot and conflict-centred drama of the Aristotelian form and the well-made play which continues to underpin, for example, Ibsen's achievement, in favour of a thematically organized dramatic structure with (ironically) an affinity with music. ${ }^{47}$ For like so many other writers and painters during the thirty years leading up the First World War, from Mallarmé and Gauguin to Kandinsky and Thomas Mann, Strindberg had recourse to analogies with music in order to validate formal experiments that were frequently the result of a desire to turn inward and explore unconscious motives, in his case in a new theatrical language. As Walter Sokel remarks:

In them [Strindberg's 'dream plays'] projection and embodiment of psychic forces take the place of imitation of external facts; association of ideas supplants construction of plot based on logical connection of cause and effect. The old structural principle of causal interrelation between character, incident, and action gives way to a new structural pattern, closer to music than to drama - the presentation and variation of a theme.... With few exceptions, Expressionist drama conforms to an "epic" or narrative, rather than to a strictly dramatic pattern. It is not based upon the clash of independently motivated characters, but upon the showing and telling of themes... A loosely connected "life story", a series of "stations," pictures, and situations takes the place of a well-knit plot. $^{48}$

Such a drama, with its espousal of musical values, is clearly likely to prove attractive to Viennese musical expressionism, not least because such readers of Strindberg in translation might justifiably find the non-verbal elements of his dramatic art, including his symbolic use of light and colour, sound, music 
and setting as important as the verbal content. Psychic projections realized visually along with the transformation of metaphors and figures of speech into stage images as in the infernal landscape of The Dance of Death or the timearresting Mummy in The Ghost Sonata not only enable the subconscious mind to be projected on stage; they also offer a new (or rediscovered) stage language to replace an exhausted realism. In its fusion of speech, song, movement, gesture, lighting, colour and music, Strindberg's practice in his post-Inferno dramas is part of the theatrical revolution of Craig, Fuchs, Appia, Meyerhold and - in due course - Artaud, a revolution that sought to re-theatricalize the theatre by rediscovering the unique expressive qualities that distinguish it from literature in its combination of spoken and/or sung language with all the other concrete languages of the stage. In this sense Strindberg achieves what Schoenberg aspires to in his lecture on Die glückliche Hand in connection with its production in Breslau in 1928, namely 'making music with the media of the stage'. And as so often in modernist art in general, where the carrying conventions of a consensual language, whether romantic or realist, have been supplanted by a new, often elliptical, grammar and syntax, it is the medium itself that is foregrounded; in this case the stage, like the other arts, aspires to the non-representational condition of music. Or as Schoenberg observed, in his essay on 'The Relationship to the Text', first published in 1912 in Der Blaue Reiter: 'When Karl Kraus calls language the mother of thought, and Wassily Kandinsky and Oskar Kokoschka paint pictures the objective theme of which is hardly more than an excuse to improvise in colours and forms and to express themselves as only the musician expressed himself until now, these are symptoms of a gradually expanding knowledge of the true nature of art' $^{3}{ }^{9}$ 


\section{A Penance for Strindberg}





\title{
12. Acting Women: or The Performing Self
}

\author{
She'd never make an actress though. \\ Just another pair of tights.
}

Dreiser, Sister Carrie

One practises the Theatre because one has the impression of never having been oneself, of being unable to be oneself, and of having discovered at last the means of being oneself... . From the outset of his career, the actor feels an emptiness, and lives on it.' This reflection by the French actor, Louis Jouvet, on the art he practised with such distinction over four decades, cuts both ways. On the one hand, it appears to celebrate variety and plenitude (as John Stokes points out, the 'signs of the theatrical performer are volatile... if only because they are signs of multiple identity - famous performers, "stars", may even achieve that complex totality of the image that semioticians call "structural polysemy"), ${ }^{2}$ on the other, it suggests a lack and hence the need for compensation (thus George Moore, in his diatribe upon 'Mummer Worship', who regarded the stage as 'a profession for the restless, the frankly vicious - for those who [seek] any escape from the platitude of their personality'). ${ }^{3}$

Either way, however, it implies that the performer is a kind of tabula rasa, someone who is at the very least characterized by a conspicuous lack of character, and who therefore becomes (or so the argument not infrequently continues) the imitator of other people's feelings while possessing none of their own. Indeed, both in anecdotes about actors and in the serious analysis of their art the suggestion that they prey upon life, drawing nourishment, vampire-like, from their own and other people's lives is almost a commonplace. One of the most widely quoted instances of this kind describes the eminent French actor, Talma, on hearing of the death of his father. According to C. -B. Coquelin, who recounts the event in his L'Art et le comédien (Art and the Actor, 1880), '[Talma] uttered a piercing cry, so piercing, so heartfelt that the artist always on the alert in the man instantly took note of it and decided to make use of it upon the stage later on'. ${ }^{4}$ Similarly, the popular French writer Ernest Legouvé, who in 1849 collaborated with Scribe in providing the great tragedienne Rachel with one of her most effective contemporary roles as her eighteenth-century 
predecessor at the Comédie-Française, Adrienne Lecouvreur, recalls how, on her deathbed, Rachel remained alert to the theatrical possibilities even of so extreme a moment: 'Her terrible sufferings now and then became plastically manifest in attitudes replete with statuesque and noble grace, attitudes of which she was perfectly conscious, for your great dramatic artist never forgets his ego even amidst the most cruel bodily and mental suffering. He is actor and spectator in one. However real his despair, he watches the rendering of it, ${ }^{5}$ a point that is endorsed by Janet Achurch who, fresh from her performance as Nora in A Doll's House, was reported by William Archer in Masks or Faces? as saying: 'It is impossible for me to help it. Everything that comes, or ever has come, into my own life, or under my observation, I find myself utilizing, and in scenes of real personal suffering I have had an under-consciousness of taking mental notes all the time. It is not a pleasant feeling. ${ }^{6}$

Masks or Faces?, the study in the psychology of acting which Archer wrote in 1888 with the assistance of a questionnaire that he had previously circulated among a number of well-known actors and actresses, was partly intended as a riposte to the theories advanced in one of the most famous of all discussions of the actor's art, Le Paradoxe sur le comédien (The Paradox of Acting) of 1773, in which Diderot mounts an eloquent defence of precisely the kind of behaviour that evidently disturbed even an experienced actress like Janet Achurch. Unlike his celebrated contemporary Rousseau, who had inveighed against the art of the actor in his recent Lettre à d'Alembert sur les spectacles (Letter to d'Alembert Concerning Spectacles) on the grounds that to counterfeit, be inconstant, and prey upon other people's experience was immoral and deeply corrupting, Diderot regarded the variousness of the histrionic personality, with its ability, like Proteus, to assume a multiplicity of guises, in a wholly positive light: for him 'the great actor is everything and nothing.' Just as Keats maintained that 'the poetic character has no self... Not one word I ever utter can be taken for granted as an opinion growing out of my identical nature, ${ }^{8}$ so Diderot questioned the argument 'that actors have no character because playing them all makes them lose the one that nature gave them, and that they become false, just as doctors, surgeons and butchers grow hard. I think people have taken the cause for the effect, and that they're only fitted to play all characters because they haven't one of their own' (or 'they are fit to play all characters because they have none').?

Moreover, whereas for Rousseau all behaviour, both on and off stage, was false unless predicated upon an identity of feeling and action, for Diderot the suggestion that a great actor like Garrick was somehow beside or other than himself in each of his various incarnations was a sign of health rather than immorality: wholly to identify with (say) Lear or Oedipus and lose all consciousness of the audience before whom one is performing means ceasing 
to be an actor and becoming a madman - or even worse, a bad actor. 'Extremes of feeling make for indifferent actors,' Diderot's First Speaker observes, 'an average amount of feeling gives you the mass of bad actors; a complete absence of feeling is what is needed for a great actor, ${ }^{10}$ and the paradox of great acting consequently resides in an actor's ability to move the spectator and yet retain possession of himself, to assume the role and yet always to judge the effects that his acting will produce, to continue to hear and see himself as he performs on stage, whatever the strength of the emotion he is portraying.

The periodic importance of Diderot's Paradoxe sur le comédien in subsequent discussions of acting is as illuminating about the status of the actor at the time it is invoked as it is about Diderot's original concerns. It is not difficult, for example, to perceive the attraction that Diderot's account of the self-conscious actor would hold for Brecht when he came to theorize his break with the kind of illusionistic theatre espoused by Archer, and there were certainly a number of reasons why it should have been topical during the 1880s in both France and England, where it appeared in translation in 1883, with a preface by Henry Irving. ${ }^{11}$ Among the more obvious was the visit of the Comédie-Française to London in 1879, which led to frequent contrasts being drawn between French and English acting styles (the one the result of training and intelligence, the other instinctive and emotional). But actors and acting were in any case general topics of current interest given, on the one hand, especially in England, the social movement during the latter half of the nineteenth century which saw the admission of actors and actresses to good society (Henry Irving,s knighthood in 1895 is, of course, emblematic of this) and, on the other, especially in France, the proliferating commercialization of the theatre, which predicated the marketing of a performers image in plays that served as vehicles for displaying his or her personal magnetism, whereby the performer (for example, Sarah Bernhardt) becomes a producer who is his - or generally her - own production.

This last phrase comes from The Tragic Muse, Henry James's unjustly neglected novel of artist life from 1890, in which a contrast is drawn between Paris and the values of art on the one hand, and London and their absence in politics and commerce on the other. Although James is ultimately concerned with questions of representation in general, as they apply to literature and painting as well as the theatre, the issue is rendered all the more acute here because the tragic muse of his novel is the actress Miriam Rooth, and hence an artist who is her own material. For as Coquelin had stressed, again in Art and the Actor: 'The instrument of the actor is himself. The matter of his art, that which he has to work upon and mould for the creation of his idea, is his own face, his own body, his own life, ${ }^{12}$ a fact which, at least in the illusionist tradition of the Western theatre, only serves to point up the issue of how questionable any feeling is at the moment of its theatrical representation. As 
an actress, Miriam's integrity is measured in her seeming to feel what she says when she is speaking words produced by someone else, and as she is told, by one of her admirers: 'What's rare in you is that you have - as I suspect, at least - no nature of your own... Your feigning may be honest, in the sense that your only feeling is your feigned one.'.13

The issue is again the one raised by the Paradoxe sur le comédien, but The Tragic Muse approaches it in a context that is shaped by a number of other theatre novels (most immediately, Edmond de Goncourt's anatomy of an actress, La Faustin (1887), Arsène Houssaye's La Comédienne (1884), Zola's Nana (1880), and Mrs Humphrey Ward's Miss Bretherton (1885), based on the career of the American actress, Mary Anderson), all of which are symptomatic of their time. Although finely and individually drawn by James, Miriam is therefore in some respects a representative figure. For example, like Rachel, the common ancestress of many of these nineteenth-century actress portraits, she is Jewish, and consequently perceived as racially marginal, equivocal, and naturally histrionic (a similar link is made in Daniel Deronda as well as in Arthur Symon's short fiction 'Esther Kahn' and Oscar Wilde's The Portrait of Dorian Gray, but the identification drew contemporary sanction from Sarah Bernhardt, who had just stood model for Félicien Champsaur's novel, Dinah Samuel). More particularly, Miriam is also depicted as a protean figure in continual flux, at home nowhere and everywhere, cosmopolitan but impoverished and unschooled ('ignorant, illiterate, Rachel', runs one of James's notes), ${ }^{14}$ the possessor, like Wedekind's Lulu, of whom she is the unexpected relative, of several names as well as the obligatory sphinx-like air of the finde-siècle, in short, an attractive chameleon who bears only the countenance of the occasion, as a sequence of representative movements in which she takes on the appearance, voice and gestures of whoever she happens to be with, and yet who embodies (if that isn't a contradiction in terms) the prevailing view of the actress as someone who is essentially devoid of personality, a void or 'vacancy', whose very variety is symptomatic of her lack of substance. 'I don't know what's in her,' remarks her early mentor, a diplomat called Sherringham, 'nothing, it would seem, from her persistent vacancy,', and again: 'The expression that came nearest to belonging to her... was the one that came nearest to being a blank - an air of inanity when she forgot herself, watching something.' ${ }^{16}$

In short, performers like Miriam are nothing in themselves, but merely who or what they pretend to be, a conclusion which the ultimately irremediably bourgeois Sherringham clearly finds disturbing:

It came over him suddenly that so far from there being any question of her having the histrionic nature, she simply had it in such perfection that she was always acting; that her existence was a series of parts assumed for the moment, each changed for the next, before the perpetual mirror 
of some curiosity or admiration or wonder - some spectatorship that she perceived or imagined in the people about her.... It struck him abruptly that a woman whose only being was to 'make believe', to make believe that she had any and every being that you liked, that would serve a purpose, produce a certain effect, and whose identity resided in the continuity of her personations, so that she had no moral privacy, as he phrased it to himself, but lived in a high wind of exhibition, of figuration - such a woman was a kind of monster, in whom of necessity there would be nothing to like, because there would be nothing to take hold of. ${ }^{17}$

So extended a quotation is justified because James's analysis of Miriam Rooth serves to raise a number of related issues which transcend the more or less parochial debate concerning the state of the British theatre in the 1880s. They include what Jonas Barish's excellent book of that name has defined as 'the antitheatrical prejudice, ${ }^{18}$ the on and off stage representation of women, and what might be called the psychopathology of the late nineteenth century in general, all of which emerge with particular force at this juncture because they are foregrounded by the kind of deconstruction of the idea of a single indivisible self currently being undertaken by James's close contemporaries Nietzsche and Strindberg, and which is subsequently developed from Ibsen by Freud. Indeed, James's revelation of the multiplicity and variety of the performing self in The Tragic Muse is as much a part of this wider European dimension as it is of any short-winded Anglo-Saxon great tradition, and demands consideration in relation to (for example) Strindberg's account of the modern self in the preface to Miss Julie as the 'split and vacillating' formation of an 'hysterical age' which is patched together out of 'agglomerations of past and present cultures, scraps from books and newspapers, fragments of humanity, torn shreds of once-fine clothing that has become rags' [SV 27, 104-5], or to an admittedly minor anecdote like his story 'Jubal utan jag' (Jubal without a Self), in which the account of a singer who plays so many roles that he ultimately forgets who he is, is based in part on Strindberg's one-time friend, the opera singer Algot Lange, and partly on Johan Ludvig Heiberg's portrait of the actor in 'En Sjæl efter Døden' (A Soul After Death), who had prayed to so many gods during his stage career that when dying he no longer knew on whom to call, and could not recite the Lord's Prayer without the assistance of the prompter [SS 37, 93-101]. But in such texts the multiplicity and variety of the performing self not only suggests the discontinuity of consciousness and the mobility of identity in general; it also invokes the historical moment. In what came increasingly to be regarded as the arena of urban display and city facades in which everyone was conscious of acting a role (restricting discussion to novels that concern themselves with the theatre, both Zola's vision of Paris in Nana and Herman Bang's portrait of Copenhagen in Stuk (Stucco) are relevant here), the actor by profession seemed 
to exemplify the urgent problem of how to appraise the authenticity of anyone's behaviour when everyone may be other than he or she appears, whose self in the constantly changing incarnations that he or she adopts can never be known, and for whom inconsistency and a lack of fixity in relationships and character may quite possibly be a sign of health rather than a lack of moral fibre.

I say actor, but in most contemporary discussions of the theatre, and almost without fail in the novels with which The Tragic Muse is linked, the focus of attention is upon the actress. On one level, this reflects the fact that during the nineteenth century it was the principal actress who became major box-office while male performers, with a very few exceptions such as Irving and Salvini, took second place. The international theatrical icons of the time, for example, are Bernhardt, Duse and Réjane, who succeed Rachel and the Italian actress, Adelaide Ristori. However, on another level, the idea of the actress was associated with the prevailing view of woman. Woman was seen precisely to represent the notion of the performing self, or Strindberg's 'characterless character': she was by nature - or so the doxa ran - multiple, duplicitous, unstable, and constantly changing (her mind or her hats); she was consistent only in her inconsistency, and remained, with her Gioconda smile and the obsession that she supposedly shares with the actress for gazing at herself in the mirror, an enigma or a sphinx. Or as Nietzsche, who habitually turns nineteenth-century prejudice into pseudo profundity, observes, in Human, All Too Human, multiplicity might be equated with absence, or the emptiness that Sherringham had identified in Miriam, and as such women are necessarily theatrical: 'There are women who, however you may search them, prove to have no content but are purely masks. The man who associates with such almost spectral, necessarily unsatisfied beings is to be commiserated with, yet it is precisely they who are able to arouse the desire of the man most strongly: he seeks for her soul - and goes on seeking. ${ }^{19}$ Indeed, for Nietzsche, woman epitomizes the pretence of essence. With her mimic gifts, deception, dissimulation and the donning of masks are 'natural' to her, until he depicts her 'essence' as subsumed by the multiplicity of masks she wears, precisely as the actor's is.

The actress had often been defined in terms of her power of metamorphosis and her lack of character before, of course. In Wilhelm Meisters Lehrjahre (Wilhelm Meister's Apprenticeship, 1795-96), for example, Goethe had portrayed Philina as an irresponsible, prodigal, giddy, inconstant personality, whose ability as a dancer and an actress sprang from a seemingly boundless but superficial capacity for mutability and imitation, thus provoking the now familiar comment: 'Character... and do you think such a woman has a character?' ${ }^{20}$ Indeed, it is the sense of these same qualities in Miriam that so offends Sherringham's sensibility; the histrionic conscience, as he 
defines it, 'unscrupulous, nervous, capricious, wanton', ${ }^{21}$ is 'necessarily... vulgar', ${ }^{22}$ and he can ultimately draw no real distinction between the serious actress and any other female performer: her face, he observes, 'was an elastic substance, an element of gutta-percha, like the flexibility of the gymnast, the lady who, at a music-hall, is shot from the mouth of a cannon... he had always looked more poetically, somehow, at that priestess of art. But what was she, the priestess, when one came to think of it, but a female gymnast, a mountebank at higher wages'. ${ }^{23}$

However, in the past such public women, with all the overtones that phrase conveys, had generally been drawn in explicit contradistinction to the private woman. Indeed, in taking exception here to female rather than male display, Sherringham is wholly representative. As Tracy Davis points out, in her welldocumented study of 'Actresses and Prostitutes in Victorian London', 'Female performers (regarded as a single class by the dominant culture) received the stigma [attached to displaying themselves in public] uniformly in spite of their professional specialities and socioeconomic diversity. ${ }^{24}$ Like the whore, the actress was an object of desire, whose company was purchased through commercial exchange by customers who 'tacitly agreed to suspend disbelief while a particular desire was gratified.' And as Davis adds, 'in both contexts, the vehicles of gratification were women whose identity, sincerity, and appearance were illusory but whose success relies on not giving away the hoaxes of the consumer's control of full reciprocity or enjoyment.' ${ }^{25}$

For the conspicuousness of the actress at work and, when famous, at home contravened the bourgeois separation of public and private spheres: whether a serious performer or a shameless cabotine, the behaviour of the professional actress was incompatible with a woman's properly gendered upbringing. As Rachel Brownstein argues, in her study of Rachel's impact on Charlotte Brontë (the latter, who portrayed Rachel as Vashti in Villette, saw her as a force of nature, with 'the feelings and fury of a fiend'), ${ }^{26}$ the private woman has a singular, permanent identity. She does not display herself and belongs to the family, not the crowd. Her life is private and her sexuality concealed. 'Above all she does not act,' Brownstein observes, 'a lady is served. And of course she does not, as the psychoanalysts say, "act out"; instead, literally, she suffers in. The power she may have over others arises not from anything she does but from what she consistently is: unlike the actress, she does not change. ${ }^{27}$ Moreover, whereas the actress is widely depicted as essentially cold, the parasitical and unfeeling purveyor of fake emotions, her customary foil, the faithful wife, is portrayed as consistently her warm, sincere, and modest self, wholly unable to dissemble or feign. ${ }^{28}$

Now, as A.B. Walkley remarked, in his essay on 'The Histrionic Temperament' of 1892, 'deep down in the hearts of most men there persists 
the feeling that to make a public show of yourself for money, to be always expressing ideas not your own, and emotion which you do not feel, to pretend in short to be what you are not - to clap a hump on your back and call yourself Richard the Third, as Johnson put it - is to violate the dignity of a citizen and a free man, to resign the "captaincy of your soul"' ${ }^{29}$ But what made the issue so pertinent to Walkley's contemporaries, as they passed the figure of the actress in review during the late nineteenth century, is that to the otherwise quite various masculine gaze of (for example) James and Zola, Wilde or Symons, and the Goncourt brothers or Havelock Ellis, the female stage performer was seen as identical with women generally: in short, all women were actresses by nature.

As a specimen of its kind, here is Symons in 'Extracts from the Journal of Henry Luxulyan', from the same collection that includes his actress fiction 'Esther Kahn':

What a thing it is to be a woman, and how perplexing are even their virtues! They are not made, as we are, all of a piece; they are not made to be consistent; they think so little of what we think so much of; even sex is a light, simple, and natural thing to them, to which they attach none of our morbid valuations... Think of the daily habits of their life: how many times a day they dress and undress themselves, and all it means. With each new gown a woman puts on a new self, made to match it. All day long they are playing the comedian, while we do but sit in the stalls, listen, watch and applaud. At least the play is for our entertainment: we pay them to act it: let us be indulgent if the acting is not always to our taste. ${ }^{30}$

The same argument was put, as usual more succinctly, by Nietzsche, in The Gay Science of 1881, where he likewise universalized women even as he suggested the necessity of their mendacious behaviour: 'Reflect on the whole history of women: do they not have to be first of all and above all else actresses?... love them - let your self be "hypnotized by them"! What is always the end result? That they "put on something" even when they take off everything. ${ }^{31}$ Indeed, in those discourses in which the nineteenth century liked to explore the 'natural' differences between men and women, for example, in Darwin's The Descent of Man, the former were judged as superior to women in courage, energy, intellect and inventive genius while women had the edge in terms of intuition, perception and imitation, although it is true that those faculties were also 'characteristic of the lower races, and therefore of a past and lower state of civilization, ${ }^{32}$ as well as of children, thus rendering her both phyloand ontogenetically retarded. Havelock Ellis, meanwhile, in his widely read study Man and Woman, noticed 'an interesting parallelism, and probably a real deep-lying nervous connection, between the suggestibility of women and the special liability of female butterflies, birds, and mammals to be mimetic 
in coloration, ${ }^{33}$ which led him to argue that women naturally excelled in 'at least one art... the art of acting' since, among other things, 'the circumstances of women's social life have usually favoured a high degree of flexibility and adaptability as regards behaviour; and they are, again, more trained in the vocal expression both of those emotions which they feel and those emotions which it is considered their duty to feel. ${ }^{34}$

In support of his argument Ellis quotes Rachel's colleague Legouvé on the mobile, ardent, and varied impressionability that acting requires, and which consequently makes 'the dramatic faculty... more native to women than to men'. ${ }^{35}$ He might equally well have quoted the very incarnation of contemporary theatricality, Sarah Bernhardt, whose book, L'Art du théatre, declared that acting 'contains in itself all the artifices which belong to the province of woman: the desire to please, the facility to express emotions and hide defects, and the faculty of assimilation which is the real essence of woman $^{\prime 36}$ (although had he done so, he would doubtless not have noticed, as Elaine Aston does, in her recent monograph on Bernhardt, that if the language of the theatre is indeed a female language, acting for Bernhardt 'was no longer simply a question of parading as a desirable love-object, but rather a baring of the female psyche - the inner female life made visible through its language of body, face and voice'). ${ }^{37}$

But so subtle a reading of the actress, who emerges as both an image of woman and a woman composed of images, cannot conceal the dangers inherent in this nineteenth-century view of acting women, for whom role-play is frequently linked with the notion of foreplay and subsequent prostitution. Like the prostitute, the actress was engaged in what Sherringham called 'nightwork', ${ }^{38}$ and she was likewise easily seen as abandoning her body to the multitude, since her body was the instrument through which her art gave pleasure. For as Barish observes, 'when we alter or diversify for pleasure, when the body is made the instrument of that pleasure, when the pleasure is available to anyone who can pay for it...the activity turns into a form of metaphysical prostitution for which no loathing can be too strong and no repudiation too absolute, ${ }^{39}$ and to the nineteenth-century imagination this image of the actress effortlessly shedding or assuming names and identities, and displaying - like Wedekind's Lulu - an obliging adaptiveness to the whims of her male customers, amongst whom she circulates as a commodity within the capitalist economy of male desire, was both attractive and repellent. In so far as they did not signify the sexual body so much as its production as an elaborate spectacle, a commodified image, both prostitute and actress could be seen as offering themselves promiscuously to the passer-by, and they likewise shared not only their working hours and a lack of personal identity which, in the light of Diderot's paradox, might manifest itself most acutely when each absented themselves from authentic feeling at the 
moment of greatest passion, but also the possibility of a rare social mobility and a concern with costume and make-up in a flickering, gas-lit world where both solicited the attention of the concupiscent male gaze. ${ }^{40}$ Indeed, the intoxicating realm of the theatre, which included an actress's training, her costume and its fitting, make-up, green rooms, dressing rooms and stage-doors, housed a complex sexual system, and released a powerful erotic charge, as is indicated by the Goncourts' description of a first night at the Cirque:

The balcony was resplendent with demi-mondaines and the corridors were crowded with those handsome men wearing foreign decorations who fill the corridors of the Opera on ball nights. In the boxes there was quite a pretty array of prostitutes. It is wonderful what a centre of debauchery the theatre is. From the stage to the auditorium, from the wings to the stage, from the auditorium to the stage and from one side of the auditorium to the other, invisible threads criss-cross between dancers' legs, actresses' smiles and spectators' opera glasses, presenting an overall picture of Pleasure, Orgy, and Intrigue. It would be impossible to gather together in a smaller space a greater number of sexual stimulants, of invitation to copulation. It is like a Stock Exchange dealing in women's nights. ${ }^{41}$

The same might also have been said (indeed, it often was) about any of the other available theatrical venues - whether for ballet, opera, music-hall, masked ball, circus, or the café concert, with its corbeille of young women sitting in silent display behind the singer - and when, in Nana, Zola has his theatrical manager, Bordenave, describe the theatre at which Nana makes her debut as 'mon bordel' (my brothel), this was as much a commonplace as forthright naturalism. The Goncourts, for example, record M. Hiltbrunner, the manager of the Théâtre des Délassements, telling the architect Cabouillet, 'Monsieur, my theatre is a brothel', ${ }^{42}$ and Zola in fact modelled his theatre on the Variétés, where the first half-dozen rows were always reserved for male spectators seeking post-performance pleasures.

It is, however, the frequent identification of the prostitute as someone who moves easily between roles in a play of intriguing signs and changing masks that marks perhaps the most significant point of identification with the actress, and consequently with the conception of the performing woman that I have been tracing here. ${ }^{43}$ One way forward would therefore be to examine the numerous plays in which actresses were required to perform the role of actress on stage. Modestly conceived in Britain, and concerned more with manners and morals than art, such roles were generally deployed to confirm the prevailing social order. Thus, in Robertson's Caste (1867), where a dancer marries into the aristocracy and leaves the stage, it is her experience as a performer that helps her adapt to the milieu in which she now finds herself. In Pinero's Trelawny of the 
Wells (1898), meanwhile, the brief experience (lasting all of one month!) that the actress Rose enjoys in a genuine upper-class milieu renders her incapable of playing her old parts successfully when she returns to the stage. She has been touched by true refinement, and can no longer dissemble: 'I was nothing but an actress,' she laments, 'We are only dolls, partly human, with mechanical limbs that will fall into stagey postures, and heads stuffed with sayings out of rubbishy plays... It isn't the world we live in, merely $a$ world - such a queer little one! I was less than a month in Cavendish Square, and very few people came there: but they were real people - real! ${ }^{\text {44 }}$

After such an effusion, a comparison with the less inhibited theatrical portraits of the actress in France and Germany comes as some relief. Whereas the moral of mid-century plays like Meilhac and Halévy's ubiquitous Frou-Frou (1869) implicitly echoed Wilkie Collins's No Name (1862) - or indeed Mansfield Parkin suggesting that an ability to transform oneself into someone else was morally dangerous, and that true innocence could therefore be measured in terms of a character's lack of ability as a performer, by the end of the century the actress was frequently being celebrated in all her 'infinite variety'. This is the case with Meilhac's Ma Cousine (1890) and Berton and Simon's Zaza (1898), both of which were devised as vehicles for Gabrielle Réjane. At one point in the latter, Réjane is in fact discovered in precisely the kind of milieu that had made Flaubert's nostrils flare, namely an actress's loge at a café concert in Saint-Etienne, performing the role of an actress performing her toilette, dressing, making-up, unpinning her false hair, and dabbing her shoulders with a powder puff, ${ }^{45}$ a scene that is almost contemporary with the extraordinary third act of Wedekind's Erdgeist (Earth Spirit, 1895), in which Lulu is shown backstage, changing her costumes under the gaze of her mentor, Dr Schön, as Wedekind explores both the ambiguities of theatrical representation in general, through the suggestive parallel between the on-stage actress, who is pretending to be an actress, and her off-stage existence, and the more general predicament of a woman who has been allotted her role by a male creator, who is motivated at least in part by his sexual fantasies. ${ }^{46}$ And this in turn recalls one of the most enduring plays of the later nineteenth century, namely $A$ Doll's House (1879), in which Ibsen effectively subverts the prevailing notion of woman as a player of roles. Through his portrait of Nora Helmer being rehearsed by her husband in the roles that he has sought to inculcate in her, one may see both the process by which she has been constructed as a woman to serve the male interests of contemporary society and the way in which, in the final act, she takes off the fancy-dress costume in which he has attired her, and dons her own clothes, in order to seek her own life as herself.

It is intriguing, and surely no coincidence, that the scene in which her husband's dressage reaches its climax should be the hysterical tarantella, brought back by the Helmers from Capri, which Nora dances at the close 
of Act Two. ${ }^{47}$ As Catherine Clément and Hélène Cixous point out, in their revealing study of La Jeune née (The Newly Born Woman), ${ }^{48}$ the Southern Italian woman's dance of the tarantella includes, among other movements, the classic arc of the hysteric as defined in the manuals of late nineteenth-century French psychology, and the hysteric (as Freud and Breuer would shortly suggest, in their Studies on Hysteria of 1895) transforms her body into a kind of theatre where she replays scenes from the past that she cannot otherwise express, just as Nora dances what she cannot say. In fact, at the close of a century in which the male imagination displayed a febrile obsession with the figure of Salome, a delight in dancing was frequently regarded as typical of female neurasthenia, ${ }^{49}$ and any such link between dancing, women, roleplaying and hysteria ought therefore to alert us to the possibility of a further resonance in the nineteenthcentury notion of acting women. For if the model of fashionable womanhood during the 1850s and 1860s was the grande cocotte, or courtesan, many of whom, like Thérèse Lachmann, Cora Pearl or Lola Montez, used the theatre as a means of staging their beauty, for the fin-de-siècle she was supplanted by the hysteric. Indeed, again and again in contemporary accounts of prominent actresses from this period, it is their kinship with the hysteric that is stressed. Gilles de la Tourette, for example, the author of a Traité clinique et thérapeutique de l'hystérie (Clinical and Therapeutic Treatise on Hysteria), published in Paris, in 1891, admired Aimée Desclée's assumption of the title role in Frou-Frou for being 'like a singularly precise and well observed type of worldly hysteria,' ${ }^{50}$ and as John Stokes has pointed out, Desclée's modernity was identified with neurosis in the precise, clinical meaning of the word. A.B. Walkley, meanwhile, dubbed Réjane 'the muse of hystero-epilepsy' for her ability to 'so cleverly reproduce the gradual crescendo from nervous irritation to suffocating or shrieking hysteria, ${ }^{51}$ while to Arthur Symons, as to many others, including her visual chronicler, Toulouse-Lautrec, the morbid and enigmatic Jane Avril, who had indeed spent much of her youth in clinical care for chorea, embodied the pathological choreography of the fin-de-siècle in her dancing at the Moulin Rouge..$^{52}$ Likewise, Eleonora Duse was widely praised for her ability to 'outclass everyone in her portrayal of characters with hysterical temperaments'. ${ }^{53}$ Thus Adelaide Ristori, who was otherwise often lukewarm about her younger compatriot, acknowledged Duse's achievement in creating 'for herself a sort of convention that is quite hers, through which she effectively becomes the woman of modern times, with all her complaints of hysteria, anaemia and nerve trouble, ${ }^{, 54}$ as did, in almost the same words, a female commentator in the Fortnightly Review, for whom she appeared 'In brief... the modern actress, the fin de siècle woman par excellence, with her hysterical maladies, her neurotism, her anaemia and all its consequences. ${ }^{55}$ Hugo von Hofmannsthal, meanwhile, also intending praise, christened her 'Our Lady of the Quivering Nerves. ${ }^{56}$ 
From this it was again only a step to seeing all women as not merely actresses but also hysterics, especially when, to many female as well as male spectators, Duse seemed to represent woman rather than a sequence of different women's roles. Thus one of Strindberg's old sparring partners, Laura Marholm, insisted that what Duse 'gave us [was] the secret, inner life of woman which no poet can wholly fathom, and which only woman herself can reveal, ${ }^{, 57}$ and Helen Zimmern maintained that 'she is before all else a woman, in every sense of the term - a woman and not an actress. ${ }^{58}$ Indeed, during the last thirty years of the nineteenth century, histrionics and hysteria were inextricably linked in the male imagination, and continued to be so well on into the present century when (for example) Fritz Wittels may be observed remarking, in a widely disseminated study of 1956 on Freud and His Time, that 'dramatic art should be the true domain of the hysteric, for she is always playing a part, never taking herself or the world seriously. ${ }^{59}$ But today the divided consciousness of the actress imitating (as Diderot suggests in his Paradoxe) the movement, actions, gestures, the entire expression of a being altogether beyond herself, someone who was either beside herself in her role or lost in her part as she mouthed a script that she had not written herself, recalls nothing so much as the celebrated Tuesday seminars and Friday spectacles that were staged regularly at the hospital of La Salpêtrière in Paris by the French neurologist Jean-Martin Charcot. Sometimes dubbed the 'Napoleon of neurosis', he and his cast of generally young and attractive female patients performed what Georges Didi-Huberman calls 'la pantomime des symptômes, ${ }^{60}$ before a predominantly male audience that frequently included eminent writers like Maupassant, Edmond de Goncourt, and Alphonse Daudet, as well as leading actors and actresses, painters, journalists and demi-mondaines. ${ }^{61}$ Charcot was in fact one of the most masterly of the many metteurs-en-scène produced by the theatrical age of the Belle-Epoque: when he lectured on tremors, for example, three or four women were introduced wearing hats with very long feathers. The trembling of the feathers allowed the audience to distinguish the specific characteristics of the tremors caused in various diseases. ${ }^{62}$ As a skilled mimic, Charcot would also imitate the gait, behaviour, and voice of a patient for his audience himself, but what particularly drew le Tout-Paris to his lectures was the dramatic presentation of the various stages of la grande hystérie itself, performed in a vast amphitheatre which contained both RobertFleury's famous painting of 1887 depicting Pine! freeing the insane following the first French Revolution, and a lithograph of Charcot himself, lecturing in the guise of a scientific Svengali on a pliable, swooning, and half-undressed young woman, to a group of admiring and attentive men. Although he helped pioneer the recognition of hysteria as a male affliction, it is significant that the photographic record of Charcot's experiments, the Iconographie de la Salpêtrière, 
does not contain a single male portrait: his stars were all women, like his prima donna, Blanche Wittmann, otherwise known as 'la reine des hystériques' for her talent at reproducing every stage of the major attack, from dancing via the epileptoid, to clowning and what was provocatively called 'attitudes passionnelles', or her fifteen-year-old co-star, Augustine, whose re-enactment of the violation that had in all likelihood precipitated her affliction made her 'un véritable prodige de plasticité, un véritable prodige de théâtralité. ${ }^{63}$ Under hypnosis, which partly secured the division of the performer into the acting and feeling being of Diderot's paradox, and with the expressivity of actresses repeating their roles beneath the insistent gaze of a répétiteur, these women acted out their identifications, adopting poses, reliving roles, and re-enacting the past, as they embodied a pre-existing and unconscious script before the eyes of a male spectator who, as in the theatre of the time, was an essential part of the performance. Consequently, it is hardly surprising to discover that a playwright, André de Lorde, should have collaborated with the clinician Alfred Binet in dramatizing Charcot's lessons at the Salpêtrière in several plays, including Une Leçon a la Salpêtrière, first performed at the Grand Guignol in $1908 .^{64}$

Even before Charcot, however, the hysteric had been perceived as essentially an actress. Thus Jules Falret, in his Folie raisonnable ou folie morale (Reasonable Madness or Moral Madness) of 1866, explained: 'These patients are real actresses; they have no greater pleasure than in deceiving the people with whom they have some relationship, ${ }^{65}$ and the remedy proposed for such 'hardened actresses' by the Victorian doctor, Thomas Clifford Allbutt, had been to empty the theatre and take away the audience by placing the patient in solitary confinement. Charcot's own records of his sessions are in fact sometimes written up in dialogue form (perhaps helping the patients, and the doctors who coached them, to perfect their roles in advance: Blanche Wittmann later confessed that, even under hypnosis, she had - like a Diderotian actress - always been conscious of her enactment), and the photographic material produced at the Salpêtrière likewise provides a veritable thesaurus of theatrical gestures, which were sometimes given titles like 'Lady Macbeth' or 'The Actress'. Indeed, as Elaine Showalter remarks, of the frequently photographed Augustine, who for her audience at least possessed the fortunate gift of being able to divide her attacks into scenes and acts with tableaux and intermissions (in fact, she appeared before the camera so often that she developed an additional hysterical symptom of seeing the world in black and white): 'All of her poses suggest the exaggerated gestures of the French classical acting style, or stills from silent movies. ${ }^{66}$

As Charles Bernheimer points out, at best 'Charcot's theater had one tremendous attraction for its equivocal stars: it afforded suffering women a 
stage on which to express their desire, in however displaced and disguised a form, ${ }^{67}$ and in this gallery of symptoms from which the patient's subtext might eventually be gleaned, there is something of the ability that Hofmannsthal noted in Duse to 'act the transitions; she fills the gaps of the motivation; she reconstructs the psychological novel in drama, ${ }^{68}$ though only, it would seem, when she had lost herself in a role and become, like the hypnotized patient, the antithesis of Diderot's always conscious actor. It is, however, as a Trilby-like somnambulist, who acts as if in a magnetic sleep, that the actress is frequently portrayed at this time, by (for example) Symons in 'Esther Kahn' or Theodore Dreiser in Sister Carrie. This is a strategy that enables the male author, like the audience at the Salpêtrière, to gratify a desire in which women are regarded as at once debased and out of control and the rewarding if dangerous stimuli to creation. In their protean mutability, the actress and hysteric are merely the avatars of all women, as is suggested by the Goncourts in their novel Germinie Lacerteux (1864), whose humble heroine is overheard in hysterical delirium to speak just like the great Rachel (which is perhaps hardly surprising since Charcot had judged Jews to be disproportionately susceptible to hysteria and mental illness generally) ${ }^{69}$ : 'her language became as unrecognizable as her voice, transposed into the tones of a dream. This soared above the woman herself, above her normal tone and expression... The phrases came from her mouth with their rhythm, their heartbreak and their tears, as from the mouth of a wonderful actress... such acting, such intonations, a voice as dramatic and as broken as this voice, like that of a consumptive spitting out her heart - she only recalled these things in Mlle Rachel. ${ }^{2}{ }^{70}$

The construction of gender entails both the product and the process of its representation, and at the end of the nineteenth century woman, in the form of the actress, appeared as the very ground of representation, a false universal constituted by the concuspicent male gaze, which located in her image the site of male desire. At times, of course, she colluded in that process. As Laura Mulvey points out, 'in their traditional exhibitionist role women are simultaneously looked at and displayed, with their appearance coded for strong visual and erotic impact so that they can be said to connote to-be-looked-at-ness, ${ }^{171}$ a moment that Wedekind captures so memorably when, in Earth Spirit, Lulu asks the painter Schwarz whether he wishes her to pose for him with her lips slightly parted..$^{72}$ In both theory and practice the most extreme incarnations of the fin-de-siècle actress portray her as a self-regarding solipsist, engaged in reinforcing the naturalized assumptions of the prevailing ideology, whether 'subtly of herself contemplative'73 like Rossetti's Lilith or Mallarmé's mirrorgazing Hérodiade, or discovered on stage, as Symons describes Maeterlinck's mistress, the actress and singer Georgette Leblanc, seemingly absorbed entirely in herself: 'When I heard her [sing],' Symons writes, 'there was a mirror on 
the other side of the room, opposite her; she saw no one else in the room, once she had surrendered herself to the possession of the song, but she was always conscious of the image of herself which came back to her out of the mirror: it was herself watching herself, in a kind of delight at the beauty which she was evoking out of the words, notes, and expressive movement. ${ }^{34}$

In this role, too, which is of course that of Walter Pater's Gioconda and her enigmatic, exclusive smile, the now almost impersonal, inactive woman once again eludes definition: like the actress Miriam Rooth with whom we started, she remains a void or vacancy. But in the new century, as Nora asserts her independence in the guise of Freud's Dora by adopting what Jacques Lacan once called 'the smile of the Mona Lisa', ${ }^{75}$ this vacancy, or seeming lack of definition that woman supposedly shares with the actress (or indeed, the actor), will assume a positive charge, as for example in Julia Kristeva's revisioning of woman, in her essay 'Woman Can Never Be Defined': 'A woman cannot "be”; it is something which does not even belong in the order of being. It follows that a feminist practice can only be negative, at odds with what already exists.... In "woman" I see something that cannot be represented, something that is not said, something above and beyond nomenclatures and ideologies. ${ }^{76}$

But no more can the actor, which partly accounts for the depth and venom of the anti-theatrical prejudice. Whatever else it may be, in the Western tradition at least acting of any worth is a celebration of variety and difference, of being other and more than one ordinarily is. Thus it retains the necessary power to disturb and change the world in which it comes to life; and although, as the great nineteenth-century Danish actress, Johanne Luise Heiberg, once remarked, 'the strange thing about such imaginative creatures... is that every footprint they make on their way through life immediately fills up again behind them, ${ }^{77}$ in this emptiness, or evanescence, remains the potent sign of an inexhaustible plenitude. ${ }^{78}$ 


\section{Notes}

\section{Chapter One - Little Further than Gravesend: Introducing Strindberg to England}

1. When the drama was revived with the same cast two years later the reviewer in The Era (18 February 1911) remarked that 'Lady Tree ... won the applause of a delighted audience thoroughly interested in the playlet.' Javorskaja had some experience in performing Strindberg. She had previously appeared in Crimes and Crimes, The Father and Miss Julie in Russia. (See Nils Åke Nilsson, 'Strindberg på rysk scen', Meddelanden från Strindbergssällskapet, 20 (1956), 5-16.) Moreover, in a letter to Strindberg, dated 8 March 1911 [XIX, 235], Birger Mörner recalls Javorskaja telling him that she had wanted to appear in Miss Julie in England, but had been forbidden to do so by the censor.

2. For the early reception of Strindberg on the British stage and in print, see the first part of Esther H. Rapp's 'Strindberg Bibliography', Scandinavian Studies, 23:1 (1951), 1-22, from where these examples are taken. Where the absence of humour is concerned the critic in question had of course not had the opportunity of seeing Laurence Olivier in the role of Edgar in The Dance of Death at the National Theatre in 1967.

3. See Rapp, p. 11.

4. Strindberg. A Biography (London, 1985), p. 578.

5. For Strindberg in France, see Anthony Swerling, Strindberg's Impact in France 1920-1960 (Cambridge, 1971). His early impact on the German stage is discussed in Hans-Peter Bayerdörfer, Hans Otto Horch and Georg-Michael Schulz, Strindberg auf der deutschen Bühne. Eine exemplarische Rezeptionsgeschichte der Moderne in Dokumenten (1890 bis 1925) (Neumünster, 1983).

6. Rapp, p. 11.

7. Quoted by Michael Meyer in Strindberg. Plays: Three (London, 1991), p. 188.

8. August Falck, Fem år med Strindberg (Stockholm, 1935), p. 173.

9. Charles Archer, William Archer (London, 1931), p. 303. See also Anthony Swerling, 'Bernard Shaws besök hos Strindberg', Artes, 5 (1981), 121-27.

10. Bernard Shaw, Collected Letters 1898-1910, edited by Dan H. Laurence (London, 1972), pp. 906-7.

11. The Letters of Sean O'Casey, 1910-1954, edited by David Krause, 2 vols (New York, 1975), I, p. 217, II, p. 568-9.

12. Craig's memories of Strindberg are summarized by Meyer in his biography, p. 466. 
See also Gösta M. Bergman, Det moderna teaterns genombrott (Stockholm, 1966) and Strindberg's Letters, pp. 726-8, where Strindberg reports that he and his friends 'made ourselves as horrible as we could' to Craig who was, Strindberg observed revealingly, 'like Oskar [sic] Wilde: der war mir zu schön' [XV, 231; 2, 726].

13. For Reinhardt and Strindberg, see, in the first instance, Kela Kvam, Max Reinhardt og Strindbergs Visionare Dramatik (Copenhagen, 1974).

14. Theatre and Friendship. Some Henry James Letters with a commentary by Elizabeth Robins (London, 1932), p. 34.

15. Essays on Strindberg, edited by Carl Reinhold Smedmark (Stockholm, 1966), p. 70.

16. Quoted in Michael Meyer, The Plays of Strindberg, 2 vols (London, 1964), I, p. 26.

17. Published in Philadelphia (1924), New York (1927) and Ann Arbor (1930) respectively.

18. The Academy, 31 May 1913, p. 682.

19. The Drama of Ibsen and Strindberg (London, 1962), pp. 45, 460-61.

20. August Strindberg, Selected Letters, edited and translated by Michael Robinson, 2 vols (London and Chicago, 1992).

21. See e.g. Olof Lagercrantz, August Strindberg, translated by Anselm Hollo (London, 1984), pp. 355-6.

22. En dåres försvarstal, translated by Hans Levander (Stockholm, 1977), p. 141.

23. The Portable Nietzsche, edited and translated by Waiter Kaufmann (New York, 1954), p. 664. See the whole of Nietzsche's diatribe in Nietzsche contra Wagner, concluding 'In the theater one becomes people, herd, female, pharisee, voting cattle, patron, idiot - Wagnerian' (p. 666) and Andreas Huyssen's discussion of the phenomenon in 'Mass Culture as Woman: Modernism's Other', in Studies in Entertainment, edited by Tania Modleski (Indiana University Press, 1986), 188-207.

\section{Chapter Two - Translating the Self}

1. Euvres complètes, edited by Bernard Gagnebin and Marcel Raymond, 4 vols (Paris, 1959-69), I, p. 118

2. Euvres complètes, I, p. 175.

3. Euvres, edited by André Billy (Paris, 1951), pp. 1007-8. Translated by Geoffrey Bemner in Denis Diderot, Selected Writings on Art and Literature (Harmondsworth, 1994), p. 105. For an important discussion of Diderot's ideas on acting in relation to the private self, see Richard Sennett, The Fall of Public Man (New York, 1977; London, 1986), chapter six.

4. 'Semble avoir deux âmes, l'une qui note, explique, commente chaque sensation de sa voisine de l'âme naturelle, commune à tous les hommes.' Guy de Maupassant, Sur l'eau (Paris, nd), pp. 115-6.

5. Henry James, The Tragic Muse (Harmondsworth: Penguin edition, 1978), p. 88. Cf. Miriam with Diderot's portrait of Mlle Clairon: "II wish you could see yourself," Sherringham answered. "My dear fellow, I do. What do you take me for? I didn't miss a vibration of my voice, a fold of my robe"' (p. 230).

6. The Tragic Muse, p. 145

7. The Tragic Muse, p. 131. 
8. The Tragic Muse, p. 130.

9. William Archer, Masks or Faces? (London, 1888), pp. 101-2.

10. Euvres, I, pp. 1030, 1037; Bremner, pp. 129, 135.

11. The Letters of John Keats 1814-1821, 2 vols (Cambridge, Mass., 1958), I, pp. 386-7.

12. 'Autobiography - Reflection Trained on Mystery', Prairie Schooner, 46 (1972-3), p. 324. Hence, too, the various recording instruments for logging the past which writers have put forward, from Locke's notion of the pre-mnemonic mind as a white page, devoid of all characters, and Diderot's soft substance of the brain as a mass of sensitive and living wax, capable of receiving new impressions while retaining and reviving the old, down to Freud's mystical writing pad.

13. The Confessions, translated by Rex Warner (New York, 1963), p. 118.

14. The Unnamable in Three Novels (London, 1959), p. 296.

15. In The Structuralists. From Marx to Levi-Strauss, edited by Richard De George and Fernande De George (Garden City, 1972), p. 163 .

16. Barthes, p. 162. Cf. Mikhail Bakhtin's observation in 'The Forms of Time and the Chronotope in the Novel', PTL 3:3 (1978), p. 526: 'Even if he is the author of an autobiography, or of the most truthful of confessions, the writer nevertheless remains, as their creator, outside the world depicted in them. If I tell of (or write about) an event which has just happened to me, I, as the teller (or writer) of this event am already outside that time-space in which this event has occurred. It is impossible to identify absolutely myself, my "I", with that "I" of which I am telling as it is to lift myself up by the hair.'

17. Standard Edition of the Complete Works of Sigmund Freud, edited by James Strachey, 24 vols (London, 1953-73), III, p. 321.

18. Journals of Anais Nin (London, 1973), I, p. 6.

19. Euvres complètes, I, p. 1153.

20. Essais de linguistique génerale (Paris, 1963), p. 33.

21. A Treatise on Human Nature (Harmondsworth: Penguin Edition, 1969), p. 302.

22. A Treatise on Human Nature, p. 310.

23. Ecrits, translated by Alan Sheridan (London, 1977), pp. 46-7.

24. 'Autobiography - Reflection Trained on Mystery', p. 325.

25. David Hume, My Own Life, in Charles W. Hendel, ed., An Inquiry Concerning Human Understanding (New York, 1966), p. 3; Charles Darwin and Thomas Henry Huxley, Autobiographies edited by Gavin de Beer (Oxford, 1983), p. 8.

26. Euvres complètes, I, p. 1149.

27. 'The Value of Narrativity in the Representation of Reality', Critical Inquiry, 7 (1980), p. 8.

28. A Treatise on Human Nature, p. 301.

29. Peter Brooks, Reading for the Plot (Oxford, 1984), passim.

30. Ivar Lo-Johansson, Pubertet (Stockholm, 1978), p. 137.

31. A History of Autobiography in Antiquity, 2 vols (London, 1950), I, p. 4.

32. Jerome Buckley, The Turning Key: Autobiography and the Subjective Impulse (Cambridge, Mass., 1984), p. 40.

33. Collected Shorter Plays of Samuel Beckett (London, 1984), p. 234.

34. The Tragic Muse, p. 146. 


\section{Chapter Three - Life, Plots and Letters}

1. Peter Brooks, Reading for the Plot (Oxford, 1984), p. 3.

2. Kerstin Dahlbäck, Ändå tycks allt vara osagt. August Strindberg som brevskrivare (Stockholm, 1994), p. 9.

3. Ever resourceful in utilizing his literary remains, Strindberg deployed much of this material in a less revealing form in 'The Quarantine Master's Second Story' in the collection Fairhaven and Foulstrand (1902).

4. See, for example, XIII, p. 28 and XV, pp. 38, 42.

5. Euvres complètes, ed. Bernard Gabnegin et Marcel Raymond, 4 vols (Paris, 195960), I, p. 1153.

6. 'The Purveyor of Truth', Yale French Studies, 52 (1975), 31-113 (p. 34).

7. 'The Value of Narrativity in the Representation of Reality', Critical Inquiry, 7 (1980), 5-25 (p. 8).

8. Reading for the Plot, p. xiii.

9. Strindberg-ett förattarliv, III (Stockholm, 1985), p. 101ff.

10. See Colour Plate VI in Torsten Måtte Schmidt, ed., Strindbergs måleri (Malmö, 1972), facing p. 112.

11. SgNM 9, 6 .

12. Ockulta dagboken, facsimile edition (Stockholm, 1977), p. 130.

13. James Joyce (Oxford, 1959), p. 1.

14. Anton Chekhov, Plays, translated by Elisaveta Fen (Harmondsworth, 1959), pp. 307-8.

15. Chekhov, Plays, p. 167.

16. Quoted in Robert Brustein, The Theatre of Revolt (New York, 1964), p. 154.

17. Roman Jakobsen, Verbal Art, Verbal Sign, Verbal Time (Oxford, 1985), p. 124.

\section{Chapter Four - History and His-Story}

1. Hayden White, Metahistory: The Historical Imagination in NineteenthCentury Europe (Baltimore, 1973), p. 39.

2. For a translation of 'The Mysticism of World History', see August Strindberg, Selected Essays (Cambridge, 1996), pp. 181-222. This supersedes a previous translation of part of this essay by the same translator in Comparative Criticism 3 (1981). For a discussion of Strindberg's essay, see Göran Printz-Påhlson, 'Allegories of Trivialization: Strindberg and History', Comparative Criticism, 3, pp. 221-36.

3. 'The Burden of History', History and Theory, 5:2 (1966), 111-34.

4. The Son of a Servant, translated by Evert Sprinchorn (London, 1968).

5. 'Autobiography and Historical Consciousness', Critical Inquiry, 1:4 (1975), 821-48 (p. 821).

6. Johann Wolfgang von Goethe, The Autobiography of Johann Wolfgang von Goethe, translated by John Oxenford, 2 vols (Chicago, 1974), p. 2.

7. Hippolyte Taine, History of English Literature, translated by H. van Laun, 4 vols (New York, 1895), I, p. 34.

8. On Strindberg and Moleschott, see The Son of a Servant [SV 20, 124] and Torsten Eklund, Tjänskvinnans son. En psykologisk Strindbergsstudie (Stockholm, 1948), pp. 245-6. 
9. Graham Smith, Waterland (London, 1983), p. 53.

10. Søren Kierkegaard, Concluding Unscientific Postscript, translated by David F. Swenson and Walter Lowrie (Princeton, 1941), p. 141.

11. Matthew Wikander, The Play of Truth and State: Historical Drama from Shakespeare to Brecht (Baltimore, 1986), p. 192.

12. See Nils Norman's perceptive analysis of the Napoleonic imagery in Strindberg's texts, both literary and (if the distinction may be drawn) epistolary in 'Strindberg och Napoleon', Svensk litteraturtidskrift, 22:4 (1959), pp. 151-70.

13. Michael F. Kaufman, 'Strindberg's Historical Imagination: Erik XIV, Comparative Drama, 9:5 (1975-6), pp. 318-31.

14. Perhaps they are not intended to. As the character of Swedenborg remarks in Carl $X I I$, of the king's perplexing fate: 'We may not understand it perhaps! I have never understood a single human destiny, not even my own' [SV 47, 147].

15. 'History' in Essays: First Series (1841). Strindberg's final book collection, now preserved in the Strindberg Museum at 85 Drottninggatan, in Stockholm, contains two German translations of this collection.

\section{Chapter Five - P-aris: Notes for an Unwritten Volume of Strindberg's Autobiography}

1. 'Om strindbergsstudier', Bonniers Litterära Magasin, 1969:6, 406.

2. For an English translation of 'Sensations détraquées', see August Strindberg, Selected Essays (Cambridge, 1896), pp. 122-34.

3. For brief accounts of Grétor's role in Strindberg's life, see Strindberg Letters II, pp. 557-8 and Selected Essays, pp. 252-4.

4. See Stellan Ahlström, 'Barbaren i Paris', Ord och Bild, 1947.

5. Gunnar Brandell, Strindbergs infernokris (Stockholm, 1950). Translated by Barry Jacobs as Strindberg in Inferno (Cambridge, Mass., 1974).

6. Although Strindberg was unaware of it, Wedekind did pose a threat of a kind, having embarked on an affair with Frida Uhl, with whom he subsequently had a child.

7. Strindberg's dramer, 2 (Stockholm, 1926), 1.

8. Originally published in Ystads Allehanda, 19 September 1970, as 'Vem förföjlde Strindberg? Kryptogram blev utmaning', Hallén's article is now most readily accessible in French in Obliques. Littérature-Théatre, 1, pp. 63-8. The passage in question is included, in translation, in August Strindberg, Selected Essays, p. 137 and decoded on pages 252-4.

\section{Chapter Six - Naturalism and the Plot in Creditors}

1. For Brandes' criticism of Creditors, see Edvard Brandes, Om Teater, edited by H. Engberg (Copenhagen, 1947). Strindberg's response may be gauged from a letter of 9 March 1889 to the Swedish writer Ola Hansson, in which he accuses Brandes of 'mala fides' in attacking him for 'moralizing' and justifies his own practice in Creditors as 'evolutionary morality. One nature is justified or unjustified by another = determinism $=$ indifferentism!!!'. See VII, 272; 1, 309-10. 
2. Reading for the Plot (Oxford, 1984), p. 6.

3. 'The Study of Architecture in Our Schools', in The Works of John Ruskin, 39 volumes (London, 1904), XI, p. 243.

4. Notes on Life and Letters (London, 1924), p. 18. The ironic tone of Conrad's comment echoes the way in which Strindberg acknowledges the problem of closure by drawing attention to the artificiality of his plot within the text of Creditors itself.

5. See Strindberg's Letters, 1, pp. 274-5.

6. Compare this with Strindberg's fear, expressed in a letter to Siri von Essen, that Wrangel might 'scrape out every word I wrote in your soul' [I, 350].

7. 'You have here,' Strindberg informed Brandes, while sending him a copy of Miss Julie, 'an attempt at la nouvelle formule adapted to our single requirements: make the pain brief, let the action spend itself in a single movement. ... In France I always had 5 lamb chops, much to the astonishment of the autochtons. For the chop comprised half a pound of bone and two inches of fat, which I left. Within this there was a ball of lean meat, la noix! That I ate. Give me the nut is what I'd tell the playwright!' [VII, 184; 1, 291].

8. Birger Mörner, Den Strindberg jag känt (Stockholm, 1924), p. 140.

\section{Chapter Seven - Prisoners at Play}

1. Egil Törnqvist, Strindbergian Drama: Themes and Structure (Stockholm, 1982), p. 138.

2. References to Endgame are to the Faber edition (London, 1958). Page references are identified in parenthesis in the text.

3. Ross Chambers, 'An Approach to Endgame', in Twentieth-Century Interpretations of Endgame, edited by Bell Gale Chevigny (New Jersey, 1969), 71-81 (p. 78).

4. See Hummel's comment, 'My whole life has been like a fairy tale' [SV 58, 172] and Milton May's essay, 'Strindberg's Ghost Sonata: Parodied Fairy Tale on Original Sin', Modern Drama, 10 (1967), 189-94.

5. Waiting for Godot (London, 1956), p. 94.

6. See Kela Kvam, Max Reinhardt og Strindbergs Visionere Dramatik (Copenhagen, 1974), p. 18ff. Compare the performance of the opening and closing scenes in a more recent production at the Royal Dramatic Theatre in Stockholm, directed by the playwright Lars Norén. Here, Edgar (Jan Malmsjö) and Alice (Marie Göranzon) are first glimpsed in the doorway of an inner room holding each other by the hand as the audience enter. The waltz from The Merry Widow is heard and the pair dance in, he in uniform and she in a white dress, saying the opening lines of Strindberg's text. These are then repeated and the audience is suddenly projected twenty-five years on in time to the opening of the play as written. At the end the pair repeat the same lines, thus closing the circle. See, too, the illustration in Richard Bark, 'Strindbergsuppsättningar 1993-1996', Strindbergiana, 12 (1997), p. 125.

7. 'Beckett's Letters on Endgame', The Village Voice Reader, edited by Daniel Wolf and Edwin Fancher (New York, 1962), 182-5 (p. 183).

8. Fin de partie (Paris, 1957), pp. 79-80.

9. Collected Shorter Plays of Samuel Beckett (London, 1984), p. 31.

10. Anthony Easthope, 'Hanun, Clov, and Dramatic Method in Endgame', in Twentieth Century Interpretations of Endgame, 61-70 (p. 66). 
11. See Hans Lindström, 'Vad händer i Dödsdansen?', in Från Snoilsky till Sonnevi, edited by Jan Stenkvist (Stockholm, 1976), 62-75 (p. 64).

12. 'Beckett's Letters on Endgame', p. 185.

13. See, for example, Martin Lamm, Strindbergs dramer, II (Stockholm, 1926), p. 222.

14. Samuel Beckett, Proust and Three Dialogues with Georges Duthuit (London, 1965), p. 67. As for Strindberg, Beckett's reading of Schopenhauer's The World as Will and Representation encouraged this view. The Proust essay quotes Calderon ('Pues el delito mayor/Del hombre es haber nacido') to support this contention, as does Schopenhauer in Book III, $\$ 51$.

15. Collected Shorter Plays, p. 230.

16. On the location of Beckett's works, see Michael Robinson, 'From Purgatory to Inferno, Beckett and Dante Revisited', Journal of Beckett Studies, 5 (1979), 69-82. Strindberg declares that 'life was a penal colony for crimes committed before we were born 'in The Son of a Servant [SV 20, 33]. His later position, which owes much to Swedenborg, and indicates the climate of The Dance of Death, is conveyed by a late manuscript note in the Royal Library in Stockholm: 'If this existence is already purgatory or an inferno for crimes we have previously committed we are all demons, here to torment each other, and when we are driven against our will to do evil, we are only doing our duty, but suffer all the same from the fact that we have done wrong. This is the double curse of existence. No one has the opportunity of tormenting one another as thoroughly as a man and a woman who love one another (= hate one another).' SgNM 6:14, 4.

17. See the exchange between the Captain and Kurt: 'Surely you're not so childish as to believe in hell? / Don't you, who are in the midst of it? / I was only speaking metaphorically. / What you described was no metaphor, poetic or otherwise' [SV 44, 77].

18. Samuel Beckett, Murphy (London, 1963), p. 76.

19. See Deirdre Blair, Samuel Beckett (London, 1978), p. 340, and James Knowlson, Damned to Fame: The Life of Samuel Beckett (London, 1996), pp. 384-5.

20. For example, by Orley Holtan in 'The Absurd World of Strindberg's The Dance of Death', Comparative Drama, 1967, 199-206.

21. Anthony Swerling, Strindberg's Impact in France 1920-1960 (Cambridge, 1971), p. 90 .

22. Thus he maintains, with scant regard for sense or context, that Strindberg's stage directions indicating that Alice withdraws the band Edgar Wishes to take [SV 44, p. 74] and the latter's line, 'Give me your hand, Kurt' [SV 44, 126], lie behind Clov's refusal to touch Hamm [p. 44]. Moreover, when one Strindbergian text proves insufficient he turns to others, confidently asserting that 'The names and certain traits of Hamm's parents originate in those of the two rats in Lucky Peter, Nisse and Nille,' Strindberg's Impact in France, p. 132. He also declares that 'Jean's urging Julie to go off with him to Como after their night together is paralleled in Hamm's urging Clov to go off with him to the south and in Nagg and Nell going to Como after their engagement', p. 135.

23. Georg Lukács, 'The Sociology of Modem Drama', in The Theory of the Modern Stage, ed. Eric Bentley (London, rev. edn., 1976), 425-50 (p. 436). 
24. Lukács, p. 443.

25. Maeterlinck, 'Silence', in The Treasure of the Humble, translated by Alfred Sutro (London, 1908), 3-21 (pp. 4, 17).

26. On the claustral nature of much modern drama, see Thomas R. Whitaker, 'Playing Hell', Yearbook of Modern Language Studies, 9 (1979), 167-87.

27. John Northam, Ibsen's Dramatic Method (London, 1953).

28. Raymond Williams, Culture (London, 1981), p. 169.

29. Williams, p. 171.

30. Waiter Benjamin, 'Paris - The Capital of the Nineteenth Century', in his Charles Baudelaire. A Lyric Poet in the Era of High Capitalism, translated by Quintin Hoare (London, 1973), 155-76 (p. 168).

31. Collected Shorter Plays, p. 248.

32. Knut Hamsun's remark is from his 1890 essay 'Fra det ubevidste Sjæleliv' (From the Unconscious Life of the Soul), but the discussion here is indebted to James McFarlane's contribution to 'Movements, Magazines and Manifesto's: The Succession from Naturalism', in Modernism, edited by Malcolm Bradbury and James McFarlane (London, 1976), 192-205 (p. 196). The image of the interior as a deep of the mind or recess of the soul is frequent in Strindberg, whose later works assume that 'we may dwell in a very beautiful apartment but we know that there is a secret room, which conceals something very ugly' [SS 46, 169].

33. Eugene Ionesco, Improvisation or The Shepherd's Chameleon, in Plays III (London, 1960), p. 150.

34. Richard Goldman, 'Endgame and its Scorekeepers', in Twentieth-Century Interpretations of Endgame, p. 38.

35. Waiting for Godot, p. 41.

36. Twentieth-Century Interpretations of Endgame, p. 38.

37. Quoted in John Pilling, Samuel Beckett (London, 1976), p. 154. The musical structure of Endgame is discussed by John Spurting in Beckett: A Study of his Plays (London, 1972), p. 71ff.

38. In Back to Beckett (Princeton, 1973), Ruby Cohn notes that in his 1967 production of Endgame, Beckett used musical terminology - legato, andante, piano, scherzo, fortissimo - to indicate his intentions to the actors (p. 153). For another account of how Beckett organizes a text 'musically', see S.E. Gontarski, 'Making Yourself All Up Again: The Composition of Samuel Beckett's That Time', Modern Drama, 23 (1980), 112-20. For an account by Strindberg of a play (Hamlet) in musical terms, as 'a symphony, polyphonically developed with independent motifs', see Open Letters to the Intimate Theatre, translated by Waiter Johnson (Seattle, 1968), p. 75.

39. For Rilke on Naturalism, see Børge Gedsø Madsen, Strindberg's Naturalistic Theatre (Copenhagen, 1962), p. 167.

40. Collected Shorter Plays, p. 62.

41. Samuel Beckett, Three Novels (London, 1959), p. 40.

42. Waiting for Godot, p. 44.

43. Niels Lyhne (Copenhagen: Det danske Sprog- og Litteraturselskab, 1986), p. 175. 


\section{Chapter Eight - Strindberg's Correspondence with Actors and Directors}

1. Euvres intimes (Paris, 1982), pp. 452, 536.

2. For more detailed discussions of Strindberg as a letter writer and his epistolary aesthetic in particular, see Kerstin Dahlbäck's major study on Strindberg as a letter writer, Ända tycks allt vara osagt. August Strindberg som brevskrivare (Stockholm, 1994), and the Introduction to Strindberg's Letters, selected, edited and translated by Michael Robinson, 2 vols (London, 1994), I, pp. vii-xvi. The letters to Siri von Essen, Elisabeth Strindberg and Emil Schering quoted here are translated in full in these volumes.

3. In fact this comment from $A$ Blue Book echoes statements in a letter he addressed to his third wife, Harriet Bosse, on the subject of letters and letter writing, in April 1908: 'Words on the tongue are so sullied that they are unable to express the highest things; what is written on the white paper is more pure!' [XVI, 251; 2, 774].

4. The Correspondence of Samuel Richardson, edited by Anna Laetitia Barbauld (London, 1804), III, p. 246.

5. Michael Robinson, Strindberg and Autobiography (Norwich, 1986), p. 62. But see chapter three, 'Writing, not Speaking: Strindberg, Language and the Self', pp. 47-84, passim.

6. Translated by Walter Johnson (Seattle: University of Washington Press, 1968). These letters and memoranda take the place of the book on acting that Strindberg sometimes considered writing, for example in a letter to Tore Svennberg: 'I intend to write a book about the Art of Acting, 40 years observations and reflections' [XVII, 245].

7. But one might also observe that throughout 1895-6, when his correspondence is otherwise prolific, there are no letters at all to any of his Swedish publishers, and only 3 during 1894.

8. One is again reminded of Richardson in the latter part of whose life 'he was rarely seen among his workmen, sometimes not twice a year, and, even when he was in town, gave his directions by little notes.' Mrs Barbauld, quoted in Malvin R. Zirker, Jr., 'Richardson's Correspondence: The Personal Letter as Private Experience', in Howard Anderson, Philip Daghlian, and Irvin Ehrenpreis, The Familiar Letter in the Eighteenth Century (University of Indiana Press, 1966), p. 73.

9. Gösta Bergman, Det moderna teaterns genombrott 1890-1925 (Stockholm, 1966), pp. 264-310 and 'Strindberg and the Intima Teatem', Theatre Research International, 9:1 (1967), 14-47.

10. See, for example, Ibsen's letter of 25 March 1887 to Sofie Reimers about Rebecca's role in Rosmersholm: 'The only advice I can give you is to read the whole play several times through very carefully, and pay particular attention to what the other characters say about Rebecca. Our actors often used to make the mistake, in earlier days at any rate, of studying their parts in isolation and without paying sufficient regard to the character's position in relation to the whole work.' Henrik Ibsen: A Critical Anthology, edited by James McFarlane (Harmondsworth, 1970), p. 92 .

11. Keir Elam, The Semiotics of Theatre and Drama, 2nd edition (London, 1988), p. 142.

12. See Edward Braun, ed., Meyerold on Theatre (London, 1969), p. 28. 
13. See e.g. XV, pp. 169-70, to Bosse: 'If you were here I would write monodramas for you! Or serve up Macbeth and Schiller's Maria Stuart, etc., as monodramas!'

14. See Herman Ring, Tearerns historia frän äldsta till nyaste tid (Stockholm, 1898), p. 220.

15. Svenska dagbladet, 21 January 1899, quoted in Gunnar Ollén, Strindbergs dramatik, 4th edition (Stockholm, 1982), p. 275. Ollén makes clear that Strindberg has in mind the heavy, elaborate, Meininger-style staging then in fashion at the Royal Dramatic Theatre.

16. Bergman, 'Strindberg and the Intima Teatern', p. 31.

\section{Chapter Nine - Towards a New Language: Strindberg's Break with Naturalism}

1. Strindbergs bildspråk. En studie i prosastil (Stockholm, 1962), pp. 276-77. Kärnell quotes from D. A. K. Aish, La Métaphore dans l'ouvre de Stéphane Mallarmé (Paris, 1938), p. 27.

2. Stéphane Mallarmé, Selected Prose Poems, Essays, and Letters, translated with an introduction by Bradford Cook (Baltimore, 1956), p. 94.

3. Mallarmé, p. 83.

4. Euvres complètes (Paris, 1951), p. 1078.

5. Euvres complètes, edited by Henri Mondor et G. Jean Aubry (Paris, 1945), p. 365.

6. The discussion here recalls the violent polemics between the art critic and historian, John Ruskin, and the Irish physicist, John Tyndall, concerning the relative values of a poetic and a scientific description of the alps, in which the two men had engaged during the 1870s. Could Strindberg, for whom the alps had become, ever since he first saw them in 1884, one of his touchstones of beauty, have been aware of this dispute? Two years later, in the vivisection 'The Battle of the Brains (Hjärnornas kamp), an apparently apocryphal article by Tyndall in The Edinburgh Review is one of the weapons that Strindberg has his autobiographical narrator deploy against the scientifically fashionable socialist Herr Schilf. See SV 29, p. 43 and SE (Cambridge, 1996), p. 41.

7. The whole passage, in which Strindberg distinguishes between a lesser and a greater naturalism is worth quoting in full. 'This is photography which includes everything, even the speck of dust on the camera lens; this is realism, a working method elevated to art, or the little art, which does not see the wood for the trees; this is the kind of misconceived naturalism which believed that art simply consisted in copying a piece of nature in a natural way, but not the greater naturalism which seeks out those points where the great battles take place, which loves to see what one does not see every day, which delights in the struggle between natural forces, whether these forces are called love and hate, the spirit of revolt, or social instincts, which finds the beautiful or ugly unimportant, if only it is great'. For a translation of this essay in its entirety, see August Strindberg, Selected Essays, pp. 73-86.

8. Roland Barthes, Camera Lucida, translated by Richard Howard (London, 1984), p. 5.

9. 'Symbolism, Decadence, and Impressionism', in Malcolm Bradbury and James McFarlane, eds., Modernism (London, 1976), p. 210. 
10. Euvres complètes, p. 1041.

11. Euvres complètes, p. 1078.

12. Euvres complètes, p. 364. The English translation is by Anthony Hartley, Mallarmé (Harmondsworth, 1965), p. 166.

13. For the use to which Strindberg puts this aperçu attributed to Talleyrand, and for his approach to language in general, see Michael Robinson, Strindberg and Autobiography: Writing and Reading a Life (Norwich, 1986), pp. 47-65.

14. On the role of Hugo and Anna von Philp in two of Strindberg's other later dramas, see the introduction to The Pelican and The Isle of the Dead, edited and translated by Michael Robinson (Birmingham, 1994), pp. 7-33.

15. See Göran Stockenström, Ismael öknen. Strindberg som mystiker (Uppsala, 1972).

16. Gunnar Brandell, Strindberg in Inferno, translated by Barry Jacobs (Cambridge, Massachusetts, 1974), p. 241.

17. Strindberg in Inferno, p. 242.

18. The Interpretation of Dreams (Harmondsworth, 1976), p. 130.

19. Cf. Mona Sandquist's speculations on the name of one of Strindberg's guides in Inferno, the physician and toxicologist Mateo José Orfila (1787-1853), whose name has been given to the Hotel in the rue d'Assas where the Parisian section of the novel reaches its climax. 'The name Orfila impels the adept to take up residence in the Hotel Orfila, where he then produces his gold. This fits very well: after all, "Or" [in Strindberg's original French text, MR] means gold and the name as a whole may be interpreted as "gold friend", or associated with "orfèvre" - goldsmith, or with Orpheus, who is one of the alchemist's mythical forerunners. The language of alchemy, the language of birds as it is called, is characterized precisely by the fact that such similarities in sound form such significant signs.' 'Inferno som alkemistroman', Strindbergiana, 10 (1995), 147-72 (p. 155).

\section{Chapter Ten - 'New Arts, New Worlds!': Strindberg and Painting}

1. Franz Kafka, Letters to Felice (Harmondsworth, 1978), p. 638.

2. See Hans-Peter Bayerdörfer, Hans Otto Horch, and Georg-Michael Schulz, eds., Strindberg auf der deutschen Bühne (Neumünster, 1983).

3. Sixten Strömbom, Konstnärsförbundets historia, 2 vols (Stockholm, 1945-65).

4. Quoted by Göran Söderström in 'Phantasies of a Visual Poet. August Strindberg as a Painter and Photographer', in August Strindberg (Amsterdam: Rijksmuseum Vincent van Gogh, 1987), p. 29.

5. Strindbergs måleri, edited by Torsten Måtte Schmidt (Malmö, 1972), p. 52.

6. Replying to a letter from Richard Bergh, who had written to tell him that 'Today I have painted the whole time with a [palette] knife - pretty good', Strindberg commented: 'A knife? If Zorn, who has the human form in his fingers, adopted the knife, he would produce Rubens, whose paintings seem to me built (with a knife) and not stroked with a brush, which destroys all life, sweeps away all traces of life and makes conscious what should be or appear "accidental"' [XVIII, 81].

7. Compare this with Caspar David Friedrich's advice: 'Close your bodily eye so that you may see your picture first with the spiritual eye. Then bring to the light of day that which you have seen in the darkness, so that it may react upon others from 
the outside inwards.' Caspar David Friedrich (London: Tate Gallery Exhibition Catalogue, 1972), p. 14.

8. T. G. Rosenthal in Schmidt, ed., p. 17.

9. Harry Carlson in Strindberg and Genre, edited by Michael Robinson (Norwich, 1991), p. 255. Carlson has since explored these ideas at greater length in Out of Inferno. Strindberg's Awakening as an Artist (Seattle, 1996).

10. For a translation of 'The New Arts! or The Role of Chance in Artistic Creation', see SE (Cambridge, 1996), pp. 103-107.

11. Quoted in Gösta Lilja, Strindberg som konstkritiker (Malmö 1957), p. 68.

12. For Strindberg's experimental photography, see Per Hemmingsson, August Strindberg som fotograf, 2nd ed. (Åhus, 1989). This edition has an extended summary in English.

13. August Strindberg Selected Essays, p. 105.

14. Hans Arp, On My Way (New York, 1948), p. 77.

\section{Chapter Eleven - Strindberg and Musical Expressionism in Vienna}

1. Alma Mahler, Gustav Mahler, new enlarged edition (London, 1973) p. 126.

2. Willi Reich, The Life and Work of Alban Berg (London, 1965), p. 32, and H. H. Stuckenschmidt, Arnold Schoenberg. His Life, World and Work (London, 1977), p. 233.

3. Olof Lagercrantz, August Strindberg (London, 1984), p. 257.

4. Carl E. Schorske, Fin de Siècle Vienna. Politics and Culture (Cambridge, 1981), p. 19 and Allan Janik and Stephen Toulmin, Wittgenstein's Vienna (New York: Simon and Schuster, 1973).

5. Though see Hilde Haider-Pregler, 'Strindbergs frühe Rezeption auf dem Wiener Theater', in Wilhelm Friese, ed., Strindberg und die deutschsprachigen Länder, Beiträge zur nordischen Philologie, 8 (Basel and Stuttgart, 1979), pp. 225-44. See also Sven Samuelson, 'Något om Strindbergsföreställningar i Wien 1899-1923', Meddelanden frän Strindbergssällskapet, 16 (1954), 3ff.

6. For Strindberg's relationship with Kraus, see Hugh Salvesen, 'The Disappointed Idealist: August Strindberg in Karl Kraus's Periodical Die Fackel', New German Studies (1981), 157-179.

7. For Strindberg and Weininger, see Waiter A. Berendsohn, 'Strindbergs krans på Weiningers grav', Ord och bild, 58:1 (1949), 23-28, and Lech Sokól, 'The Metaphysics of Sex: Strindberg, Weininger and S. I. Witkiewicz', Theatre Research International, 12:1 (1987), 39-51.

8. The Berg-Schoenberg Correspondence. Selected Letters, edited by Juliane Brand, Christopher Hailey and Donald Harris (London, 1987), p. 61.

9. Alban Berg, Letters to His Wife (London, 1971), p. 63.

10. Letters to His Wife, p. 72.

11. See Joan Alien Smith, 'Berg's Character Remembered', in Douglas Jarman, The Berg Companion (London, 1989), p. 22.

12. Letters to His Wife, p. 132.

13. See Willi Reich, Berg, p. 38.

14. Strindberg as Dramatist (New Haven and London, 1982), p. 242. 
15. The Berg-Schoenberg Correspondence, p. 117.

16. The Berg-Schoenberg Correspondence, p. 118.

17. See Stuckenschmidt, p. 183. As a letter from Berg to Schoenberg (ea. 13 September 1925) makes clear, he also later owned a copy of a collection of Strindberg's letters in the form of Emil Schering's Briefe an Emil Schering (Munich: Georg Müller, 1914). The letter bears quoting at some length for the light it sheds on Berg's relationship to Schoenberg as well as on the two composers' attitude to Strindberg: 'If, dear, esteemed friend, this year for your birthday - in spite of your antipathy for letter editions - I again present you with a volume of "letters," there are various reasons: 1.) because they are Strindberg's; 2.) because they are not private letters but communications and disclosures almost exclusively providing revelations about the last 20 years of his creativity, and this in a concise and summarized form not be found anywhere else in Strindberg's writings; 3.) because this edition also contains several previously unpublished articles and essays of Strindberg's; 4.) because the letters present an absolutely complete picture of his activities in his "modern theater" (how very like - even to the details of organization - your activities with the Verein für musikalische Privataufführungen!); 5.) because one gets to know Strindberg as letter writer; 6.) because I myself liked it all so enormously that I can't believe you, too, wouldn't get some pleasure out of it. Finally, because the volume - even unread - will complete your otherwise complete collected edition of Strindberg's works.' The Berg-Schoenberg Correspondence, p. 338.

18. John C. Crawford, 'Die glückliche Hand: Schoenberg's Gesamtkunstwerk', Musical Quarterly, IX, 583-601 (p. 584n).

19. See, for example, Strindberg's Letters, edited and translated by Michael Robinson, 2 vols (London and Chicago, 1992), II, pp. 553, 672-5.

20. Stuckenschmidt argues (Schoenberg, p. 239) that Swedenborg, mediated through Balzac and Strindberg, showed Schoenberg the way to articulate his conception of 'the unity of musical space [as] an absolute and unitary perception' as it is formulated in his 1941 essay on 'Composition with 12 Tones', Style and Idea (London, 1975), p. 223. As John and Dorothy Crawford point out (Expressionism in Twentieth-Century Music (Bloomington, 1993)), the Balzac-StrindbergSwedenborg constellation enjoyed a prominent place in the pantheon of Viennese musical expressionism during these years: 'During the relatively happy and fruitful summer of 1911, Webern was reading Bergson, Strindberg, and Balzac. The previous summer he had read Balzac's Séraphita ... In this period Schoenberg, Berg, and Webern were all caught up in a Swedenborgian quest for values, which is further articulated in the work of Balzac and Strindberg' (pp. 111-12). Nor was Schoenberg the only one to consider making Séraphita the basis of a musical composition. In 1912, Berg also planned to end a large-scale symphonic movement with the singing of words from the novel. Expressionism in Twentieth-Century Music, p. 87.

21. Jelena Hahl-Koch, ed., Arnold Schoenberg / Wassily Kandinsky. Letters, Pictures and Documents (London, 1984), p. 54.

22. Frankfurt am Main, 1956.

23. Style and Idea, p. 154. 
24. Style and Idea, p. 454.

25. Schoenberg / Kandinsky, p. 23.

26. Style and Idea, p. 142.

27. For Strindberg's transition from naturalism to modernism via the aesthetic of this essay, see “"New Arts, New Worlds!”: Strindberg and Painting' in this volume. An English translation of Strindberg's essay is included in SE (Cambridge, 1996), pp. 103-107.

28. Conversely, the Expressionist need for self-expression whatever the medium can also be seen in the work of Kandinsky, Kokoschka and Barlach who all write plays almost as readily as they paint or sculpt.

29. Donald Mitchell, The Language of Modern Music (London, 1963), p. 39.

30. Stuckenschmidt, pp. 170, 233.

31. According to Stuckenschmidt, Schoenberg first mentions Strindberg in writing when he spells out both their names in capital letters on the blank page of a letter from Hermann Bahr, dated 10 April 1909. Stuckenschmidt, p. 233.

32. Stuckenschmidt, pp. 234-5.

33. Arnold Schoenberg. Letters, edited by Erwin Stein (London, 1964), pp. 35-36.

34. Letters, p. 36.

35. See Stuckenschmidt, p. 192.

36. Josef Rufer, The Works of Arnold Schoenberg (London, 1962), p. 116.

37. The text is most readily available in Schoenberg / Kandinsky, pp. 91-8.

38. Egon Wellesz, Amold Schoenberg. The Formative Years (London, 1971; orig. Vienna, 1921), p. 29.

39. Theodor W. Adorno, The Philosophy of the New Music (London, 1973), p. 43.

40. Karl H. Wörner, 'Die glückliche Hand, Arnold Schoenbergs Drama mit Musik', Schweizerische Musikzeitung, 104:5 (1964), p. 277.

41. Quoted in Eva Steiner, "The "Happy" Hand: Genesis and Interpretation of Schoenberg's Monumentalkunstwerk', Music Review, XLI (1980), 207-22 (p. 217).

42. Wörner, p. 278.

43. Though composed earlier, the monodrama Erwartung, in which the female protagonist comes across her lover dead in the woods, also reflects this crisis in Schoenberg's life. As Ena Steiner (Op. cit.) argues, the reason why Schoenberg took an unusually long time to complete Den glückliche Hand may be accounted for by the fact that the first sketches for the libretto were written before Gerstl's suicide, and thus the Man (Schoenberg) is depicted losing the Woman (Mathilde) to the Gentleman (Gerstl). It took Schoenberg some time to come to terms with the new scenario established by the latter's death, and hence to realize the original conception which, characteristically, he would not relinquish.

44. The Berg-Schoenberg Correspondence. Selected Letters, p. 407. In the same letter (dated 9 August 1930), Berg's suggestion that Moses und Aron 'might possibly bear a superficial similarity' with some other work on the subject - presumably Strindberg's Moses in Emil Schering's German translation of 1922 - does, however, wring from Schoenberg the concession that 'I already looked at the play a year ago with that in mind' (pp. 406-7). But he continues: 'There is in fact a certain similarity, insofar as we both employ certain reminiscences of biblical language, indeed, use many literal quotations. However, in addition to other improvements, 
I am at this very moment deleting those reminiscences. Not because of the similarity with Strindberg; that wouldn't matter; but because I'm of the opinion that since the language of the Bible is medieval German, obscure to us, it can at most be used for color; and I don't need that' (p. 407).

45. Schoenberg / Kandinsky, p. 105.

46. Charles Rosen, Schoenberg (London, 1976), p. 29.

47. It is also noteworthy that while Strindberg had recourse to music as a means of structuring this new drama, both metaphorically in his own mind and in the way in which he organizes his material thematically, so Schoenberg, as he abandoned tonality and emancipated dissonance, employed the literary text as a scaffolding which enabled him 'to maintain a grasp on immediate comprehensibility at one level while daring to introduce on the other what was bound to be felt as a surrender to anarchy.' Mitchell, The Language of Modern Music, p. 30. See, for example, Style and Idea, pp. 217-8 where Schoenberg describes how he was able to go beyond the extreme expressiveness and extraordinary brevity of early atonalism by 'following a text or poem'.

48. Walter Sokel, ed., An Anthology of German Expressionist Drama (New York, 1963), pp. xiv, xx. For an account of modernism as the adoption of the principles of musical composition by the other arts, see Sokel's valuable study of Expressionism, The Writer in Extremis. Expressionism in Twentieth-Century German Literature (Stanford, 1959).

49. Style and Idea, pp. 144-5.

\section{Chapter Twelve - Acting Women}

1. Le Comédien désincarné (Paris, 1954), p. 41.

2. 'A Kind of Beauty: Réjane in London', Themes in Drama, 6 (1984), 97-119 (p. 100).

3. The Universal Review (September, 1888), 105-18 (p. 114).

4. C. -B Coquelin, 'The Art of the Actor', in Brander Matthews, ed., Papers on Acting II (New York, 1958), p. 28.

5. Ernest Legouvé, Sixty Years of Recollections, translated by Albert D. Vandam, 2 vols (London, 1893), , pp. 202-203.

6. William Archer, Masks or Faces? (London, 1888), pp. 101-2.

7. Euvres, edited by André Billy (Paris: Gallimard, 1951), p. 1030.

8. The Letters of John Keats 1814-1821, 2 vols (Cambridge, Mass., 1958), I, pp. 386-87.

9. Euvres, p. 1037. Translated by Geoffrey Bremner in Denis Diderot, Selected Writings on Art and Literature (Harmondsworth, 1994), p. 135.

10. Euvres, p. 1011. Bremner, p. 108.

11. The Paradox of Acting, translated by Waiter Harries Pollock (London, 1883).

12. Art and the Actor, p. 19.

13. The Tragic Muse (Harmondsworth: Penguin Classics, 1978), p. 145.

14. Notebooks, edited by F. O. Matthiessen and Kenneth B. Murdoch (Oxford, 1947), p. 64.

15. The Tragic Muse, p. 88.

16. The Tragic Muse, p. 130-31.

17. The Tragic Muse, p. 130. 
18. Jonas Barrish, The Anti-theatrical Prejudice (Berkeley and Los Angeles, 1981).

19. Human, All Too Human, translated by R. J. Hollingdale (Cambridge University Press, 1986), p. 152.

20. Reprint of Thomas Carlyle's translation of 1824 (New York, 1962), p. 298.

21. The Tragic Muse, p. 240.

22. The Tragic Muse, p. 155.

23. The Tragic Muse, p. 131.

24. 'Actresses and Prostitutes in Victorian London', Theatre Research International, 13:3 (1988), 221-49 (p. 232).

25. Davis, p. 227. See also Davis's articles on 'The Actress in Victorian Pornography', Theatre Journal (October, 1989), pp. 294-315, and 'Sexual Language in Victorian Society and Theatre', American Journal of Semiotics, 6 (1989), pp. 33-49, and her subsequent book Actresses as Working Women (London, 1991), in which portions of these essays are reprinted.

26. Letter to James Taylor, 15 November 1851, The Brontës: Their Lives, Friendships, and Correspondences, edited by T. J. Wise and J. A. Symington, 4 vols (Oxford, 1932), III, p. 289. For Brontë's response to Rachel, see also Chapter 23 of Villette passim, but especially the remark that she is a 'tigress' with 'a demoniac mask'. As John Stokes remarks, in 'Rachel's “Terrible Beauty": An Actress Among the Novelists', ELH, 51:4 (1984), 771-93 (p. 783): 'Vashti is Brontë's alternative version of Rachel, a fictional portrait of the living actress who embodied the truth that the representation of female desire, however diabolic it might appear, could be vehement proof of the reality of female identity.'

27. Rachel M. Brownstein, 'Representing the Self: Arnold and Brontë on Rachel', Browning Institute Studies (1985), 1-24 (p. 8).

28. This point is made, with some eloquence, in Charles Read's fiction on the life of the great eighteenth-century actress, Pegg Woffington (London, 1852). Read, who became one of Ellen Terry's mentors, had observed what he calls 'the true art of self-multiplication' (p. 27) at first hand, and his novel develops a contrast between the faithful wife, Mabel Vane, and Pegg Woffington, her husband's performing mistress. Their opposing personalities recall Diderot's paradox: Mabel's genuine feelings inhibit her from presenting herself as other than she is, even if acting a part might help her save her marriage while Pegg's attractive vitality stems from the dazzling series of roles which she plays, both in life and on stage. But what finally betrays her is precisely the feeling she has previously feigned. When Mabel expresses her anguish privately in front of what she takes to be a finished portrait of the actress, the beautiful face in the canvas is disfigured by a tear. In fact, in order to observe a private scene undetected, the actress has concealed herself behind the painting, from which she has cut away the painted face and inserted her own, but the feeling the scene arouses in her causes her living presence to break the frame of the work of art with this expression of genuine emotion.

29. Playhouse Impressions (London, 1892), pp. 235-36.

30. Spiritual Adventures (London, 1905), p. 269.

31. In a section entitled 'On the Problem of the Actor', where he also asks 'What good actor today is not - a Jew?' The Gay Science, translated by Walter Kaufmann (New York, 1974), p. 317. Kaufmann footnotes an alternative reading of the final 
sentence, 'Das sie "sich geben," selbst noch, wenn sie - sich geben': 'Literally: that they "give themselves" (that is, act or play a part) even when they - give themselves.'

32. Charles Darwin, The Descent of Man (1871; reprint, Princeton, N.J., 1981), p. 327.

33. Havelock Ellis, Man and Woman: A Study of Human Secondary Sexual Characters, 4th revised and enlarged edition (London, 1904), p. 328.

34. Man and Woman, pp. 373-74. Ellis adds: 'It is probable also that women are more susceptible than men to the immediate stimulus of admiration and applause supplied by contact with an audience.' Cf. Ellis' conclusions with Mona Caird's more understanding comment in her 'New Woman' novel of the same period, The Daughters of Danaus (London, 1894): '[Woman's] conditions have tended to develop in her the power of dissimulation, and the histrionic quality, just as the peaceful ilex learns to put forth thorns if you expose it to the attacks of devouring cattle. ... Let a man's subsistence and career be subject to the same powers and chances as the success of a woman's life now hangs on, and see whether he too does not become a histrionic enigma' (p. 226).

35. Man and Woman, p. 375, from Legouvé's Histoire Morale de la femme, 6th edition (Paris, 1874), p. 345.

36. Sarah Bernhardt, The Art of the Theatre, translated by H. J. Stemming (London, 1924), p. 144.

37. Elaine Aston, Sarah Bernhadt (London, 1989), p. 30.

38. The Tragic Muse, p. 148.

39. The Anti-theatrical Prejudice, p. 323.

40. Cf. Baudelaire, in The Painter of Modern Life, translated by Norman Cameron (New York, 1956), p. 57: 'What can be said of the courtesan can also be said, with reservations, of the actress; for the latter, too, is a manufactured confection and a thing of public pleasure.'

41. Pages from the Goncourt Journal, translated by Robert Baldick (Oxford, 1962), p. 68. Like the Goncourts, Flaubert also responded excitedly to this lubricity in the atmosphere of theatres. The Journal records them talking together 'about the odour of the theatre, that intoxicating odour composed of a basis of gas mixed with the smell of wooden flats, the smell of the dust in the wings, and the smell of gluey paint. Then we discussed the scent that rises from the stage when the curtain goes up, that heady atmosphere created by all the elements of an artificial world which, behind the curtain, makes an actress flare her nostrils and neigh with delight as soon as she comes on stage', p. 58. Flaubert's letters also record a visit to the Cirque, which he found 'enorme! ... I breathed in all kinds of smells of women and scenery, which were mixed up with the belches of the hairdresser.' Correspondence, edited by Jean Bruneau, 2 vols (Paris, 1973-1980), II, p. 621, quoted in Charles Bernheimer Figures of Ill Repute. Representing Prostitution in Nineteenth-Century France, (Cambridge, Mass., 1989), p. 312. Even the theatrical reformer and disciplinarian, Stanislavsky, acknowledged this intoxication; see $M y$ Life in Art, translated by J. J. Robins (London, 1924), pp. 47-48, 63,101.

42. Journal, ed. Baldick, p. 14.

43. See, for example, Paul de Lano's Courtisane (Paris, 1882), p. vii: 'Bored chatelaine, misunderstood bourgeoise, failed actress, corrupted peasant girl, she was all of 
these.... She is the perpetually undeciphered enigma, intriguing and terrifying man.'

44. Plays by A. W. Pinero, ed. George Rowell (Cambridge, 1986), p. 174.

45. See A. B. Walkley's review of Réjane in this scene, reprinted in Drama and Life (London, 1907), p. 291. Cf. also René Peter, Le Théatre et la vie sous le 3e République (Paris, 1947), p. 50, on the genre of the 'cubicular' play, inaugurated in 1894 by Le Coucher d'Yvette, in which any and every pretext was taken to depict a young woman undressing to go to bed, or else rising from bed to dress.

46. The ironies of such a scene are compounded when Wedekind's wife, the actress Tilly Newes, plays the role. A separate study might be devoted to the male dramatists (Strindberg, Maeterlinck, D'Annunzio, Wedekind and (possibly) Chekhov) and the vehicles they wrote for their actress wives or mistresses at the turn of the century. For Harriet Bosse and Strindberg, see Carla Waal, Harriet Bosse: Strindberg's Muse and Interpreter (Southern Illinois University Press, 1990).

47. Cf. Lola Montez' 'La Tarantule', or Spider Dance, which she claimed to have learnt from the ballerina Fanny Elssler. See Helen Holdredge, Lola Montez (London, 1957), pp. 176-77.

48. The Newly Born Woman, translated by Betsy Wing (Manchester, 1986), pp. 19-22.

49. See, for example, Harry Campbell, Differences in the Nervous Organization of Man and Woman: Physiological and Pathological (London, 1891), p. 169: 'the movements of these wild dances imperceptibly shade off into the co-ordinate movements of the hysterical fit ... Hence it is possible that the love of dancing, so peculiarly strong among women, is the outcome of a nervous organization affording a suitable soil for hysteria.' This link between hysteria and a woman who expresses her repressed sexuality in dancing continues into modernism. See, for example, Hugo von Hofmannsthal's Elektra (1903).

50. Quoted in John Stokes, 'Femme Fatale as Scapegoat: the Modernity of Aimée Desclée', New Theatre Quarterly, 6: 4 (1990), 365-78 (p. 372).

51. Drama and Life, p. 290.

52. Symons, who celebrated Jane Avril's 'morbid, vague, ambiguous grace' in his poem 'La Mélinite', continues to recall her as the fin-de-siècle hysteric in his Memoirs, edited by Karl Beckson (Pennsylvania State University Press, 1977), pp. 146-47: 'There was nothing that girl could not do: sterile as she was, but one who could exhaust others when she herself was not exhausted. At times she hardly breathed, she trembled all over, shivered, shuddered: rained her kisses on me as she embraced me her mouth on mine that ached with heat. Then her hands seized my hands, she strained them as her lips sucked at my lips. Then, as they closed inextricably, her abandoned body that was abandoned to mine became rigid with sterile ecstasies, as one sudden shiver knitted my flesh with hers.'

53. Luigi Rasis, quoted in John Stokes, Michael Booth, Susan Bassnett, Bernhardt, Terry, Duse (Cambridge, 1988), p. 142.

54. Quoted in Bernhardt, Terry, Duse, p. 137.

55. Helen Zimmern, 'Eleonora Duse', The Fortnightly Review (June 1900), 980-993 (p. 989).

56. Quoted in Henry Knepler, The Gilded Stage (London, 1968), p. 196. 
57. Laura Marholm, Modern Women: An English Rendering of Das Buch der Frauen by H. Ramsden (London, 1896), p. 97.

58. 'Eleonora Duse', p. 989.

59. Fritz Wittels, Freud and His Time (London, 1956), p. 225.

60. Invention de l'hystérie. Charcot et l'iconographie photographique de la Salpêtrière (Paris, 1982), p. 235.

61. Compare England where the psychiatrist John Conolly urged actresses playing Ophelia to visit an asylum and study real madwomen. 'An actress ambitious of something beyond cold imitation might,' he averred, 'find the contemplation of such cases a not unprofitable study.' In the 1870s Ellen Terry responded to the challenge. Yet as Elaine Showalter points out, in The Female Malady. Women, Madness and English Culture, 1830-1980 (London, 1987) p. 92, when she visited a London asylum in pursuit of material on which to build her role as Ophelia, Terry found the madwomen much 'too theatrical' to teach her anything.

62. Henri F. Ellenberger, The Discovery of the Unconscious (New York, 1970), p. 96. Compare Freud's obituary of Charcot, with whom he studied in 1885-86: 'Each of his lectures was a little work of art in construction and composition; it was perfect in form and made such an impression that for the rest of the day one could not get the sound of what he had said out of one's ear or the thought of what he had demonstrated out of one's mind ... We could almost understand how ill disposed strangers could reproach the whole lecture with being theatrical.' The Standard Edition of the Complete Psychological Works of Sigmund Freud, edited by James Strachey, 24 vols (London, 1953-74), III, p. 17.

63. Invention de l'hystérie, p. 161.

64. See Debora L. Silverman, Art Nouveau in Fin-de-Siècle France: Politics, Psychology and Style (Berkeley, 1989), pp. 89, 335.

65. Quoted in The Newly Born Woman, p. 49. Cf. the eminent physiologist, Charles Richet, 'Les Démoniaques d'aujourd'hui', Revue des Deux Mondes, 37 (1880), p. 343: 'Tout devient un sujet de drame. L'existence apparaît comme la scène du théâtre. La vie régulière, simple, facile, quamène le va-et-vient de chaque jour, est transformée par les hystériques en une série d'événements graves propres à tous les développements dramatiques.' Even more suggestively, Alfred Fouillée used a series of articles in the Revue des Deux Mondes on the experiments with hypnotism and suggestion at the Salpêtrière and (under the lead of Hippolyte Bernheim) in Nancy, to describe what he called the subterranean disaggregated parts of the self that were released during such states. 'For Fouillée this finding disclosed the mind as a psychic "theater," where a "troupe of different, multiple actors enacted an anterior drama," Silverman, Art Nouveau, p. 90. These same experiments (particularly those of Bernheim recorded in his De la suggestion dans l'état hypnotique et dans l'état de veille (Paris, 1884) and De la suggestion et de ses applications à la thérapeutique (Paris, 1886), inform the ideas on character developed by Strindberg in The Father (1887) and Miss Julie (1888), and eventually lead, with some assistance from the speculations on the theatrical aspects of dreaming in Carl du Prel's Die Philosophie der Mystik (Leipzig, 1885) to the dramaturgy of To Damascus (1898) and A Dream Play (1901).

66. The Female Malady, pp. 152-54. 
67. Charles Bernheimer, Figures of Ill Repute, p. 255.

68. Quoted in The Gilded Stage, p. 189.

69. Quoted by Sander Gilman, Disease and Representation: Images of Illness from Madness to AIDS (Ithaca, 1989), p. 169, from Alexander Pilez, Beitrag zur vergleichenden Rassen-Psychiatrie (Leipzig, 1906).

70. Edmond and Jules de Goncourt, Germinie Lacerteux, translated by Leonard Tancock (Harmondsworth, 1984), pp. 116-17.

71. Laura Mulvey, 'Visual Pleasure and Narrative Cinema', Screen, 16:3 (1975), 6-18 (p. 11). Like the ambiguities of woman as actress in general, the complexities of the kind of spectatorship Mulvey is analysing should be read in conjunction with Joan Riviere's analysis of the masquerade of femininity in 'Womanliness as Masquerade', first published in The International Journal of Psychoanalysis, 10 (1929) and reprinted in V. Burgin, ed., Formations of Fantasy (London, 1992).

72. The Lulu Plays and Other Sex Tragedies, translated by Stephen Spender (London, 1972), p. 21.

73. The Works of Dante Gabriel Rossetti, revised and enlarged edition (London, 1911), p. 100.

74. Plays, Acting and Music (London, 1903), p. 20. Cf. Symons's lines on Jane Avril, 'La Mélinite: Moulin Rouge', London Nights (2nd edn 1897), 'Alone, apart, one dancer watches / Her mirrored, morbid grace: / Before the mirror, face to face, / Alone she watches / Her morbid, vague, ambiguous grace.'

75. 'Dora distances herself from Freud with the smile of the Mona Lisa', 'Intervention sur le transport', Ecrits (Paris, 1966), p. 244.

76. 'Woman Can Never Be Defined', in Elaine Marks and Isabelle de Courtivron, eds., New French Feminisms (Brighton, 1981), p. 137.

77. In the essay 'Er skuespilkunsten en moralsk berettiget Kunst?' (Is Acting a Morally Justified Art?) of 1870, which appeared in Heiberg's posthumously published autobiography, Et liv genoplevet i Erindringen (Copenhagen, 1890-91). Quoted here from the revised 5th edn (Copenhagen, 1974), Bind IV, 1856-82, p. 218.

78. Since this study was written, the issues it raises have received attention from (among others) the contributors to Ursula Geitner, ed., Schauspielerinnen: Der theatralische Eintritt der Frau in die Moderne (Bielefeld, 1988) and Renate Möhrmann, ed., Die Schauspielerin. Zur Kulturgeschichte der weiblichen Bühnen kunst (Frankfurt a.M., 1992). See also Per Stounbjerg, 'Kvindens teatriske indtog i det moderne. Myter om kvinden som skuespillerinde hos Rousseau, Almqvist, Strindberg, Zola ...', Kritik, 116 (1995), 44-53, and 'Offentlige kvinder. Lulu, Kristina og den modeme myte om skuespillerinden', in Irene Iversen and Anne Birgitte Rønning, eds., Modernismens kjønn (Oslo, 1996, 25-41). 


\section{Index}

Achurch, Janet, 7, 17, 152

Adelphi Play Society, 5

Adorno, Theodor, 136; Philosophy of the New Music, 143

Åhman, Svea, 96

Albee, Edward, Who's Afraid of Virginia Woolf, 77

Allbutt, Thomas Clifford, 164

Anckarström, Jacob Johan, 47

Anderson, Mary, 154

'Anna O', 139

Antoine, André, 7

Appia, Adolphe, 94, 101, 148

Aragon, Louis, 111; Le Paysan de Paris, 130

Archer, William, 4-6, 9, 153; Masks or Faces?, 17,152

Arp, Hans, 126; Papiers déchirés, 128

Artaud, Antonin, 115, 148

Aston, Elaine, 159

'Augustine', 164

Augustine, St., 18

Austen, Jane, Mansfield Park, 161

Aveling, Eleonora, 7

Avril, Jane, 162

Bacon, Francis, 112

Bakhtin, Mikhail, 169

Balzac, Honoré de, 16-17, 40, 116; Séraphîta, 139, 141-142, 179

Bang, Herman, Stuk, 155

Barish, Jonas, 155, 159

Barrie, J M, 6; Peter Pan, 6, 173

Barthes, Roland, 18, 124; Camera Lucida, 108

Baudelaire, Charles, 106, 108; L'Art romantique, 111

Bauer, Felice, 115

Beckett, Samuel, 10, 18, 44, 143; All That Fall, 74; Endgame, 71-86, 144; Footfalls, 143; Ghost Trio, 83; Happy Days, 79, 83; How It Is, 77; Krapp's Last Tape, 143; Molloy, 85; Murphy, 78; Play, 47, 65, 72, 83; That Time, 24; Three Dialogues with Georges Duthuit, 84; Waiting for Godot, 73, 85

Benjamin, Walter, 82
Berg, Alban, 135, 137; Lulu, 146

Berg, Helene, 137

Bergh, Richard, 54, 106, 118, 125, 177

Bergman, Gösta, 94

Bernhardt, Sarah, 153-154, 156; L'Art du théâtre, 159

Bernheim, Hippolyte, 185

Bernheimer, Charles, 164

Bertish, Suzanne, 8

Berton, Pierre, Zaza, 161

Binet, Alfred, 164

Björling, Hedvig Amanda (Manda), 5, 92, 95, 97-99

Bjørnson, Bjørnstjerne, 4, 22, 87, 91

Blin, Roger, 4, 78

Böcklin, Arnold, 79

Bonnier, Albert, 91

Bonnier, Karl Otto, 91, 107

Bosse, Abr., 100

Bosse, Harriet, 81, 91, 93, 96, 100, 122

Brandell, Gunnar, 28, 56, 113

Brandes, Edvard, 42, 63, 65, 67

Brandes, Georg, 67, 113

Brecht, Bertolt, 46, 153

Breton, André, 111, 126; Nadja, 130

Bretonne, Rétif de la, 41

Brontë, Charlotte, 182; Villette, 157

Brooks, Peter, 25, 28, 63

Bulman, Joan, 9

Caesar Augustus, 46

Caird, Mona, The Daughters of Danaus, 183

Cantzler, Axel Leopold, 124-125

Carlson, Harry, 123

Casanove, Charles de, 5

Cazalis, Henri, 106

Cervantes, Miguel de, Don Quixote, 22, 36

Champseur, Félicien, Dinah Samuel, 154

Charcot, Jean-Martin, 163-165

Charpentier, Georges, 55

Chekhov, Anton, 3-4, 81, 83, 1116; The Cherry Orchard, 84, 97; Ivanov, 37; The Seagull, 36; Three Sisters, 36

Chekhov, Michael, 7 
Chernyshevsky, Nicolai, 106

Cixous, Hélène, 162

Clairon (Claire Legris de Latude), 15

Clément, Catherine, 162

Collins, Wilkie, No Name, 161

Conrad, Joseph, 65

Coquelin, Constant-Benoît, 181; L'Art et le comédien, 151, 153

Corneille, Pierre, Cinna, 46

Craig, Edward Gordon, 7, 94, 101, 148; On the Art of the Theatre, 100

Crawford, John, 138, 144

Dagens Nyheter, 117

Dahlbäck, Kerstin, 25

Dahlström, Carl E W L, 9

Darwin, Charles, 20, 28, 43, 111, 158

Daudet, Alphonse, 163

Davis, Tracy, 157

Dehmel, Richard, 138, 141; Weib und Welt, 139

Delacroix, Eugène, 55; Jacob Wrestling with the Angel, 55

Delblanc, Sven, 53

Desprès, Suzanne, 93

Derrida, Jacques, 28

Desclée, Aimee, 162

Dickens, Charles, 116

Diderot, Denis, 15-16, 24, 152, 159, 164; Le Paradoxe sur le comédien, 15-17, 94, 153$153,163-164$

Didi-Huberman, Georges, 163

Dörum, August, 93-95

Dostoyevsky, Feodor, 135

Dreiser, Theodore, Sister Carrie, 151, 164

Dreyfus, Albert, 48

Duse, Eleonora, 156, 162-163, 165

Easthope, Anthony, 75

L'Echo de Paris, 56

Egerton, George (Mary Chavelita Dunne), 8; Keynotes, 8

Ekström, Per, 118

Eliot, George, 40

Ellis, Havelock, 158-159; Man and Woman, 158,183

Ellmann, Richard, 36

Emerson, Ralph Waldo, 51

Ernst, Max, 126; Beyond Painting, 128

Essen, Siri von, 1, 5, 34, 43, 66, 88, 91, 94 , 99, 172

Eysoldt, Gertrud, 89
Fahlstedt, Eugène, 34

Falck, August, (b. 1843), 91

Falck, August (b. 1882), 5, 90, 92-93, 95-101

Falkner, Fanny, 98

Falret, Jules, Folie raisonnable ou folie morale, 164

Farr, Florence, 7

Flaubert, Gustave, 161, 183; Madame Bovary, 22, 36,

Fliess, Wilhelm, 35

Flygare, Anna, 95

The Fortnightly Review, 4, 5, 184

Fouillée, Alfred, 185

Fouquier, Henry ('Columba'), 55-56

Frankenfeldt, Hilma, 92

Freud, Sigmund, 10, 18, 35, 83, 114, 135-136, 140, 155; 'Dora', 166; Interpretation of

Dreams, 114; Studies on Hysteria, 139, 162

Friedrich, Casper David, 177

Fries, Elias, 112

Fröding, Gustav, 5

Fuchs, Georg, 94, 148; Die Schaubühne der Zukunft, 100

Futterer, Mme Charlotte, 32

Gardt, Fru, 92

Garnett, Constance, 4

Garrick, David, 152

Gauguin, Paul, 126, 147

Gaulois, Le, 53

Geijerstam, Gustaf af, 33, 42

The Gentleman's Magazine, 4

Gerstl, Richard, 146

Gibbon, Edward, 41

Gil Blas, 55

Goethe, Johann Wolfgang von, 26, 97; Dichtung und Wahrheit, 42; Wilhelm Meisters Lehrjahre, 156

Goncourt, Edmond de, 158, 163; La Faustin, 154, 160

Goncourt, Edmond de, and Jules de Goncourt, $160,165,183$

Germinie Lacerteux, 85, 165

Gosse, Edmund, 5

Göteborgs Handels- och Sjöfartstidning, 32

Grandinson, Emil, 93-95

Grein, J T, 1, 5

Grétor, Willy, see Pedersen

Gustav III, 46-47

Håkonson, Julia, 94

Halévy, Ludovic, Frou-Frou, 161

Hallén, Sverker, 58 
Hamsun, Knut, 8, 57-58, 83, 137

Hansson, Alfred, 95

Hartmann, Eduard von, Philosophie des Unbewußten, 44

Hasselberg, Per, 118

Hazlett, William, 125

Hedberg, Frans, 90, 93

Hedlund, Torsten, 22, 32-35, 53, 57, 66, 9091, 128

Hegel, Georg Wilhelm Friedrich, 44

Heiberg, Johan Ludvig, 155

Heiberg, Johanne Luise, 166

Heidenstam, Verner von, 34, 48, 91

Heinemann, William, 2

Helmecke, C A, 9

Herder, Johann Gottfried, 'Von Erkennen und Empfinden der menschlichen Seele', 43

Herrlin, Axel, 29, 110

Hill, Carl Fredrik, 124

Hillberg, Gösta, 93

Hofmannsthal, Hugo von, 136, 162, 165; Elektra, 184

Holst, Johan von, 92

Houssaye, Arsène, La Comédienne, 154

Howard, Trevor, 8

Hugo, Victor,106

Hume, David, 20-21; A Treatise of Human Nature, 19

Hunderup, Hans Riber, 91,96

Huysmans, Joris Karl, 17, 56

Ibsen, Henrik, 1-10, 40, 59, 82, 91, 95, 147, 155; A Doll's House; 7, 17, 152, 161; An

Enemy of the People, 7; Ghosts, 1, 66, 83, 109; Hedda Gabler, 30, 40; John Gabriel Borkman, 82-83, 94; The Lady from the Sea, 7; Pillars of Society, 94, 116; Rosmersholm, 175; When We Dead Awaken, 94, 116; The Wild Duck, 30, 83

Intimate Theatre, 5, 79, 90, 93, 95, 97, 100

Ionesco, Eugene, Les Chaises, 79, 83

Irving, Henry, 153, 156

Jacobsen, J P, Fru Marie Grubbe, 85, 139; Niels Lyhne, 85-86

Jakobsen, Roman, 19, 38

James, Henry, 5, 7 16-17, 158; The Tragic Muse, $16,153-155$

Janik, Allan, 136

Jarno, Josef, 136

Jarvorskaja, Lidija, 2

Johnson, Jake, 138

Josephson, Ludvig, 90, 99
Jouvet, Louis, 151

Joyce, James, 5, 36, 40, 130

Juel, Dagny, 30

Julius Caesar, 50

Kafka, Franz, 115

Kandinsky, Wassily, 139, 143, 147-148

Karl XII, 49, 51

Kärnell, Kari-Åke, 105

Kaufman, Michael, 49

Keats, John, 17, 152

Kellgren, Johan Henrik, 46

Kierkegaard, Søren, 22, 26, 44, 73, 106, 123; Concluding Unscientific Postscript, 45;

Repetition, 144, 146

Kittelsen, Theodor, 128

Kjellgren, Alrik, 98

Koch, Richert von, 92

Kokoschka, Oskar, 135, 148, 180

Kraus, Karl, 117, 135-138; Die Fackel, 136

Kristeva, Julia, 166

Lacan, Jacques, 20, 166

Lachmann, Thérèse, 162

Lagercrantz, Olof, 135

Lamm, Martin, 51, 58

Langen, Alfred, 55

Larsen, Nathalie, 91, 97

Larsson, Carl, 91

Lawson, Wilfrid, 8

Leblanc, Georgette, 165

Lecouvrer, Adrienne, 152

Legouvé, Ernest, 151, 159

Leiris, Michel, 27

Lermontov, Mikhail, 37

Lidforss, Bengt, 30

Lie, Jonas, 35, 45

Lind af Hageby, Lizzy, 9

Lindberg, August, 90-92

Linnaeus, Carl, 112

Littmansson, Leopold, 24, 33-34, 50, 54, 5657, 91, 120

Locke, John, 169

Loiseau, Georges, 54

Lo-Johansson, Ivar, 21, 27

Lorde, André de, 164

Loos, Adolf, 136

Looström, Claes, 45, 92

Loraine, Robert, 6, 8

Lucas, F L, 9

Lugné-Poë, Aurélian, 7, 55, 57

Lukács, Georg, 80

Lundegård, Axel, 37 
Lundgren, Egron, 117

McCarthy, Justin Huntley, 4-5

Mach, Ernst, 136

Maeterlinck, Maurice, 81, 85, 137-139, 165; L'Oiseau bleu, 6; Le Trésor des humbles, 81

Magritte, René, 119

Mahler, Alma, 135, 137

Mahler, Gustav, 135, 137-138

Mallarmé, Stephane, 17, 105-106, 112-114, 147, 165; Crise de vers, 107, 112

Mandel, Barret J, 18, 20

Mann, Thomas, 147

Marholm-Hansson, Laura, 7; We Women and Our Authors, 7

Marx, Karl, 7

Maupassant, Guy de, 16, 163, 168

Mayakovsky, Vladimir, 38

Meidal, Björn, @6

Meilhac, Henri, Frou-Frou, 161; Ma cousine, 161

Mendès, Catulle, 55

Meyer, Michael, 2-4, 8

Meyerhold, Vsevolod, 94, 97, 148

Michælson, Knut, 92

Michelangelo, 128

Misch, Georg, 21

Mitchell, Donald, 140

Molander, Harald, 101

Moleschott, Jakob, Der Kreislauf des Lebens, 44

Möller, Peter von, 92

Montez, Lola, 162, 184

Moore, George, 151

Mörner, Birger, 5, 68, 121, 135; En bok om Strindberg, 5

Mulvey, Laura, 165

Munch, Edvard, 17, 30-31, 82-83, 121, 128129

Musil, Robert, 135-136

Nansen, Peter, 91

Napoleon, 49

Nietzsche, Friedrich, 11, 40, 155; The Gay

Science, 158; Human, All Too Human, 156

Nilsson, Ivar, 90, 93

Nin, Anais, 19

Nolde, Emil, 119

Nordström, Karl, 118

Norén, Lars, 172

Northam, John, 82

O'Casey, Sean, 6

Ockrent, Mike, 8
Olivier, Sir Laurence, 8

O’Neill, Eugene, 6, 115; Mourning Becomes Electra, 82

Orfila, Mateo José, 177

Ostrovsky, Alexander, Vassilissa Melentieva, 2

Palmblad, Harry V, 9

Palme, August, 93

Pappenheim, Marie, 139

Pater, Walter, 166

Paul, Adolf, 1

Pearl, Cora, 162

Pedersen, Willy (alias Grétor), 55, 57-58, 121

Personne, Nils, 93

Pfaeffinger, Rosa, 58

Philp, Anna von, 177

Philp, Hugo von, 113

Pinero, Arthur Wing, Trelawny of the Wells, 160

Pinter, Harold, 81

Pirandello, Luigi, 37; Enrico Quatro, 82; Six Characters in Search of an Author, 37

La Plume, 106

Pontoppidan, Henrik, 91

Prel, Carl du, Die Philosophie der Mystik, 114, 185

Przybyszewski, Stanislaw, 30

Rachel (Elisa Félix), 151-152, 154, 156-157, 159, 165

Racine, Jean, 85; Andromache, 65; Britannicus, 15

Read, Charles, Pegg Woffington, 28

Reicher, Emanuel, 87

Redgrave, Sir Michael, 8

Reich, Willi, 135

Reinhardt, Max, 7, 9, 73, 83, 87, 89, 115

Réjane, Gabrielle, 156, 161-162

La Revue Blanche, 55

Revue des Revues, 58

Richardson, Samuel, 89

Richet, Charles, 185

Rilke, Rainer Maria, 85, 138

Ring, Herman, Teaterns historia från äldsta till nyaste tid, 100

Ristori, Adelaide, 156, 162

Riviere, Joan, 186

Robert-Fleury, Tony, 163

Robertson, T W, Caste, 161

Robins, Elizabeth, 7

Rosen, Charles, 147

Rosen, George von, 117

Rossetti, Dante Gabriel, 165 
Rousseau, Jean-Jacques, 11, 15, 19, 21, 23, 26 28, 152; Confessions, 26, 43, 48; Discours sur les sciences et les arts, 15; Lettre à d'Alembert sur les spectacles, 17, 152

Rubens, Peter Paul, 119, 177

Ruskin, John, 65, 121

Saint-Pierre, Bernardin de, 112

Salis, Rudolphe, 56

Salvini, Tommaso, 156

Sartre, Jean Paul, Huis clos, 79; Les mots, 20, 48; Les séquestres d'Altona, 82

Schering, Emil, 4-5, 7, 9, 41, 84, 87-89, 136, 138

Schiller, Friedrich, 3; Maria Stuart, 100

Schiwe, Viggo, 95

Schleussner, Elie, 2

Schneider, Alan, 76

Schnitzler, Arthur, Reigen, 30

Schoenberg, Arnold, 10, 84, 115, 135-138, 146; Erwartung, 139; Die glückliche Hand, 138, 143-148; Gurrelieder, 138; Die Jakobsleiter, 141-142; Moses und Aron, 146, 180; Requiem, 142; Verklärte Nacht, 139

Schoenberg, Mathilde, 146

Schopenhauer, Arthur, 137, 139-140

Schorske, Carl, 136

The Scotsman, 4

Scott, Clive, 40

Scott, Sir Walter, 108

Shakespeare, William, 3, 9, 46-47; Hamlet, 37, 80; Julius Caesar, 50

Shaw, Charlotte, 5

Shaw, George Bernard, 5-6, Quintessence of Ibsenism, 6

Shaw, Lucie Carr, 5

Showalter, Elaine, 164, 185

Simon, Claude, 26

Söderström, Göran, 119

Sokel, Walter, 147

Sprigge, Elizabeth, 4

Sprinchorn, Evert, 42, 138

Staaff, Pehr, 34

Stanislavksy, Konstantin, 94-96, 98

Stendhal (Henri Beyle), 27, 88; Les Souvenirs d'égotisme, 88; La Vie de Henry Brulard, 88

Stockenström, Göran, 113

Stokes, John, 151, 162, 182

Strauss, Richard, 137

Strehler, Giorgio, 115

Strindberg, Elisabeth (sister), 25-26, 30, 88

Strindberg, Greta (daughter), 91, 97

Strindberg, Johan August, works: 'Above the Clouds', 108; Advent, 4, 138; 'À la zoologie de la femme', 55; Alone, 26, 43, 56, 116; 'At the Wake in Tistedalen', 48; 'Le Barbare à Paris', 55; 'The Battle of the Brains', 176; Black Banners, 30-31, 109, 113, 115; The Black Glove, 6; A Blue Book, 88; The Bond, 95; The Burned House, 39; By the Open Sea, 44, 60, 76, 112, 126; Carl XII, 48-49, 171; The Cloister, 26, 60, 109; Creditors, 2-3, 8, 46, 50-51, 55, 57, 63-69, 77-78, 96, 101, 115-116, 136; Crimes and Crimes, 4, 30-31, 50, 55, 57, 68, 73, 87, 89, 138, 144; The Dance of Death, 6-8, 39, 7185, 144, 148; 'De l'infériorité de la femme', 55; 'Development', 45; A Dream Play, $7,10,31,40,76,84,90,100,136,138$ 140, 143; The Earl of Bjälbo, 45; Easter, 96; Erik XIV, 7, 46, 48-51, 90; Fairhaven and Foulstrand, 21; The Father, 1, 3, 8, $37,57,77,85,91,97,99,101,136,144$; 'La Genese d'une Aspasie', 30; The Ghost Sonata, 4, 7, 30, 51, 72, 78, 81, 83-85, 90, 100, 136-137, 148; The Great Highway, 99; Greece in Decline, 39; Gustav Adolf, 30, 49; Gustav III, 46-47; Gustav Vasa, 46, 48-51, 90; He and She, 66; Inferno, 3, 26, 28-29, 32-33, 43, 48, 53-58; 'In the Cemetery', 58; Jacob Wrestles, 55, 115, 141 142; 'Jubal Without a Self', 155; The Keys of Heaven, 56; Kristina, 46, 92; Legends, 26, 33, 55, 105; Lucky Peter's Journey, 6; A Madman's Defence, 11, 26, 34, 60, 63, 68, 109, 112; Master Olof, 3, 39, 45, 48, 99; Midsummer, 4; Miss Julie, 3-5, 8, 10-11, 34, $37,46,50,77,80,82,85,94,97-98,101$; 'The Mysticism of World History', 40-41, 50-51; The Outlaw, 93-94; Pariah, 95-96; People of Hemsö, 3, 9, 76, 116; Playing With Fire, 96; The Last Knight, 93, 144; The Pelican, 4, 7, 78, 82-83; The Protector of the Realm, 11, 144; 'The New Arts!', 110, 123, 140; 'Les Nombres cosmiques', 110; The Occult Diary, 113, 127; 'On the General Discontent', 107; 'On Modern Drama and Modern Theatre', 108; 'On Realism', 107; Open Letters to the Intimate Theatre, 90; 'The Quarantine Master's First Tale', 112; The Red Room, 116, 118, 123, 130; The Roofing Feast, 105; 'The Romantic Sexton on Rånö', 20; The Saga of the Folkungs, 48-49; 'Sensations detraqués', 54; Sir Bengt's Wife, 66, 97; 'Solrosen', 112; Somnambulistic Nights in Broad Daylight, 2; The Stronger, 2, 91, 99; The Son of a Servant, 10-11, 20-23, 26-29, 34, 41-44, 
49, 63-64, 77, 109, 116-117, 122; Speeches to the Swedish People, 105; Swanwhite, 98; Swedish Destinies and Adventures, 45; The Swedish People, 3, 39, 41; Toten-Insel, 78; Through Deserts to a Hereditary Domain, 146; Tschandala, 45; To Damascus, 3-4, 8, 10, 30, 33, 39, 49-50, 53, 57, 68, 73, 90, 93-94, 96, 105, 110, 113, 115-116, 120, 139-142, 144-146; 'Types and Prototypes in Mineral Chemistry', 110; The Virgin Bride, 4, 6, 93; 'A Witch', 45

Strindberg, Karin (daughter), 1

Strindberg, Kerstin (daughter), 31

Strömblom, Sixten, 117

Stuckenschmidt, Hans Heinz, 135, 141

Stuxberg, Anton, 44

Sudermann, Hermann, 135

Svennberg, Tore, 90, 175

Swedenborg, Emanuel, 106, 112-114, 139

Swerling, Anthony, 79

Swift, Graham, Waterland, 44

Symons, Arthur, 158, 162, 165; 'Esther Kahn', 154, 158; 'Extracts from the Journal of Henry Luxulyan', 158; 'La Mélinite', 184, 186

Szondi, Peter, 81, 85, 139

Taine, Hippolyte, 43; Histoire de la littérature anglaise, 43

Talma, François Joseph 151

Talleyrand, Charles Maurice de, 112

Tegnér, Esaias, 98

Le Temps, 55

Terry, Ellen, 182, 184-185

Tolstoy, Count Lev, 7

Törnqvist, Egil, 71

Toulmin, Stephen, 136

Toulouse-Lautrec, Henri de, 162

Tourette, Gilles de, 162

Tree, Sir Herbert Beerbohm, 6

Turgenev, Ivan, 39

Turner, J M W, 120-122, 125

Tyndall, John, 176

Uhl, Frida, 1, 9, 49, 55, 109, 119, 121, 126, 135,146
Vakhtangov, Evgeny, 7

Van Gogh, Vincent, 117

Vasa, Gustav, 46, 48, 50

Vauthier, Jean, Capitaine Bada, 79

Verdier, Anton de, 90

Voltaire (Franìois-Marie Arouet), 5

Wagner, Richard, 137, 139-140, 143; Tristan und Isolde, 143

Wahl, Anders de, 93

Wahlgren, Helge, 97

Walkley, A B, 157-158, 162

Ward, Mrs Humphrey, Miss Bretherton, 154

Webern, Anton von, 135, 137-138, 141; 'Schien mir's, als ich sah die Sonne', 137

Wedekind, Frank, 17, 57-58, 154, 159, 161, 165; Erdgeist, 161; Der Marquis von Keith, 58

Weininger, Otto, 135-137; Geschlecht und Charakter, 136

Weintraub, Karl, 42

Wellesz, Egon, 143

White, Hayden, 21, 28, 40

Wikander, Matthew, 26

Wilde, Oscar, 154, 158; The Portrait of Dorian Gray, 154

Williams, Raymond, 82

Williams, Tennessee, The Cat on a Hot Tin Roof, 9

Winge, Mårten, 117

Witkiewicz, Stanislaw Ignacy, 10

Wittels, Fritz, 163

Wittgenstein, Ludwig, 135

Wittman, Blanche, 164

Wörner, Karl, 144

Wrangel, Carl Gustaf, 66

Yeats, William Butler, 85

Zillig, Winfried, 142

Zimmern, Helen, 163

Zola, Emile, 10, 17, 125, 155, 158, 160; L'Assommoir, 85; Germinal, 85; Nana, 154155,160

Zorn, Anders, 177 
In this volume Strindberg's accomplishments as a dramatist are set against his achievements in other fields, as an autobiographer, painter, letter writer and theatre director. There are studies of individual plays, in which Strindberg's theatre is related both to naturalism and the theatre of the absurd, and of the role played by his life-long interest in historical drama as a means of mirroring his own experience. Other essays consider the problems posed by Strindberg's preoccupation with converting his own life into literature and the relationship between his later plays and the musical Expressionism of Schoenberg and Berg as well as the importance he placed on letter-writing as a model for writing of all kinds; these letters are also used to explore his ideas about acting and theatre generally. A recurring concern is with the extraordinary period of mental and emotional turmoil, known as the Inferno Crisis, in which Strindberg refashioned himself as a writer; not least through his ground-breaking work as a painter. The collection is prefaced by an account of the difficulties Strindberg's works have encountered in their reception in England and concludes with a 'penance for Strindberg' in the form of a wide-ranging study of the nineteenthcentury actress that re-examines the concern with character and theatricality of the earlier essays in a new context.

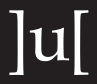

www.ubiquitypress.com

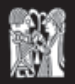

www.norvikpress.com 